\title{
VERHANDRLINGEI
}

VAN HET KONINKLIJK INSTITUUT VOOR TAAL-, LAND- EN VOLKENKUNDE

\author{
DEEL XII
}

\section{HET PASSIEVE WERKWOORD IN DE INDONESISCHE TALEN}

DOOR

Prof. Dr J. WILS

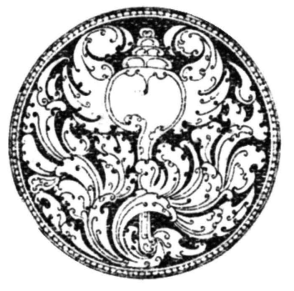

'S-GRAVENHAGE - MARTINUS NIJHOFF - 1952 
J. Wils - 978-90-04-28634-4 Downloaded from Brill. come4/26/2023 03:02:58PM via free access 
Prof. Dr C. C. Uhlenbeck

\author{
In Memoriam
}


J. Wils - 978-90-04-28634-4 Downloaded from Brill. come4/26/2023 03:02:58PM via free access 


\section{N H O U D.}

blz.

Inleiding

Eerste deel: Het pronominaal systeem der indonesische talen.

HOOFDSTUK I: De structuur van het pronominaal systeem . . 6

HOOFDSTUK II: De oorsprong der verbale subjectstekens . . . 9

HOOFDSTUK III : De „,knoop" in het pronominale systeem . . . 14

Tweede deel: Het nominaal systeem der indonesische talen.

HOOFDSTUK IV: De verhouding der beide possessieve stelsels . 19

De structuur der inalienabile groepen . . . 20

Nieuw-Pommeren 21; Marshall 23; De tanimbar-talen 26; Paulohi 28.

HoofDSTUK v: De ontwikkeling van de genitief in de oostelijke talen . . . . . . . . . . . . . . . 32

A. De ontwikkeling van de pronominale genitieftekens . . . . . . . . . . . . . 35

a. De verstarring der oude suffixen . . . . 36

b. De ontwikkeling der ,possessives” . . . . 37

c. Het indringen van de personalia in het possessieve systeem .. . . . . . . . . 40

B. De plaats van de genitief . . . . . . . . . 45

C. De constitutie van een algemene onpersoonlijke vorm bij de inalienabilia . . . . . . . . 51

a. De nieuwe nominale ,stam” . . . . . . 52

b. De pronominale vormen . . . . . . . 57

c. De meervoudsvorming . . . . . . . . 58

HOoFDSTUK vi: De ontwikkeling van de genitief in de westelijke talen . . . . . . . . . . . . . . . 59

Samenvatting . . . . . . . . . . 62

Derde deel: Het vraagstuk der flectietypen in het algemeen.

HOOFDSTUK VII: De geschiedenis van het debat over de flectietypen . . . . . . . . .

A. De periode van het ,praedicatieve” en het ,possessieve" werkwoord . . . . . . . . 65

B. De periode van het ,passieve” werkwoord . . 68

C. De reactie der ,activisten” . . . . . . . 76

D. De opvattingen in de indonesische grammatica 79

HOOFDSTUK VIII: Structurele benadering van het vraagstuk . . 82

HOOFDSTUK IX: De structuur van de subjectscategorie . . . . 86

A. De dynamiek der persoonlijke handeling . . . 88

B. De syntactische positie van het subject . . . 93 
C. De waarderingsfactor . . . . . . . . . 98

D. De nominatief als basis van het gehele casussysteem . . . . . . . . . . . . . 99

HOOFDSTUK x: De structuur van de objectscategorie . . . . 104

A. De dynamiek in de slotphase der verbale handeling . . . . . . . . . . . . . . 106

B. De syntactische positie van het object . . . . 109

C. De waarderingsfactor . . . . . . . . . . 113

D. De accusatief als de casus der eerste verbale adstructie . . . . . . . . . . . . . 115

HOOFDSTUK XI: De voornaamste syntactische verhoudingen . . 121

HOOFDSTUK XII: De possessieve flectie . . . . . . . . . 128 Moderne europese parallellen . . . . . . . 134

HOOFDSTUK XIII : Het passieve werkwoord . . . . . . . . 138

Overgangsvormen naar andere flectietypen . . 143

Moderne europese parallellen . . . . . . . 143

HOOFDSTUK XIV: Het stelsel der flectietypen in het algemeen . . 149

Vierde deel: Het verbale systeem der indonesische talen.

HOOFDSTUK XV: „Activisme” en ,passivisme” . . . . . . . 155

HOOFDSTUK XVI: Het ongeflecteerde werkwoord . . . . . . 156

HOOFDSTUK XVII: Het ,passieve” werkwoord . . . . . . . 160

A. De oostelijke talen . . . . . . . . . . . . . 163

a. De verhouding van de enclitische en de proclitische flectietypen . . . . . . . 163

Rottinees 165; Oirata 175; De tanimbartalen 177 ; Het kei 185.

b. Verbale anlautswisselingen . . . . . . 187

c. Het nieuwe casussysteem . . . . . . . . 190

B. De westelijke talen . . . . . . . . . . 191

a. De verhouding van de enclitische en de proclitische typen . . . . . . . . . . 195

a) De centraal-indonesische talen . . . 195

B) De talen van Sumatra en Java . . . . 200

$\alpha \alpha)$ De constitutie van het nieuwe proclitische verbale systeem . . . 201

De $d i$-vormen . . . . . . . . . . . . $\quad . \quad 205$

$\beta \beta)$ De ontwikkeling der objectscategorie 210 Javaans 212; Maleis 223; De Batakdialecten 227.

b. Het „omzetten" van de z.g. substantief-constructie . . . . . . . . . . . . . 230

c. De ontwikkeling van het casussysteem . . 233

C. De Philippijnse talen . . . . . . . . 234

Vijfde deel: Conclusies en samenvatting. $\quad . \quad$. . . . . 240 


\section{LIJST VAN AFKORTINGEN.}

\begin{tabular}{|c|c|c|}
\hline $\begin{array}{l}\text { AA } \\
\text { ABAW }\end{array}$ & $\begin{array}{l}= \\
=\end{array}$ & $\begin{array}{l}\text { (The) American Anthropologist. } \\
\text { Abhandlungen der Königl. Akad. der Wiss. zu Berlin, } \\
\text { Hist. phil. Klasse. }\end{array}$ \\
\hline APAW & $=$ & $\begin{array}{l}\text { Abhandlungen der Preusz. Akad. der Wiss. zu Berlin. } \\
\text { Hist. phil. Klasse. }\end{array}$ \\
\hline BTLV & $=$ & $\begin{array}{l}\text { Bijdragen tot de taal-, land- en volkenkunde, uitgegeven } \\
\text { door het Koninkl. Instituut voor Taal-, Land- en Vol- } \\
\text { kenkunde. }\end{array}$ \\
\hline BZES & $=$ & Beihefte Zeitschrift für Eingeborenensprachen. \\
\hline GRI & $=$ & Germanisch-Romanische Monatsschrift. \\
\hline HA & $=$ & Handbook of american indian languages. \\
\hline & $=$ & Indogermanische Forschungen. \\
\hline $\mathrm{KZ}$ & $=$ & $\begin{array}{l}\text { Zeitschrift für vergl. Sprachforschung auf dem Gebiete } \\
\text { des Deutschen, Griechischen und Lateinischen. }\end{array}$ \\
\hline LM & $=$ & $\begin{array}{l}\text { Les langues du Monde, par un groupe de linguistes sous } \\
\text { la direction de A. Meillet et M. Cohen, Paris } 1924 \text {. }\end{array}$ \\
\hline LI & $=$ & Linguistic Survey of India. \\
\hline & $=$ & Mitteilungen der Antropol. Gesellschaft in Wien. \\
\hline MSL(P) & $=$ & Mémoires de la Société de Linguistique de Paris. \\
\hline & $=$ & Onze Taaltuin. \\
\hline SBA & $=$ & $\begin{array}{l}\text { Sitzungsberichte der phil-hist. Kl. der Kais. Akad. der } \\
\text { Wiss. in Wien. }\end{array}$ \\
\hline TBG & $=$ & $\begin{array}{l}\text { Tijdschrift voor Indische taal-, land- en volkenkunde, } \\
\text { uitgegeven door het Bataviaasche Genootschap van } \\
\text { Kunsten en Wetenschappen. }\end{array}$ \\
\hline & $=$ & Travaux du Cercle Linguistique de Prague. \\
\hline & $=$ & $\begin{array}{l}\text { Verhandeling der Kon. Akademie van Wetenschappen } \\
\text { te A'dam. Afd. Letterkunde. }\end{array}$ \\
\hline VBG & $=$ & $\begin{array}{l}\text { Verhandelingen van het Koninkl. Bataviaasch Genoot- } \\
\text { schap van Kunsten en Wetenschappen. }\end{array}$ \\
\hline & $=$ & $\begin{array}{l}\text { Zeitschrift für afrikanische (und) oceanische (und ost- } \\
\text { asiatische) Sprachen. }\end{array}$ \\
\hline & $=$ & $\begin{array}{l}\text { Zeitschrift der Deutschen Morgenländischen Gesell- } \\
\text { schaft. }\end{array}$ \\
\hline
\end{tabular}

\section{TRANSCRIPTIE.}

Bij de transcriptie van inheemse teksten heeft de auteur van deze studie zich gehouden aan het systeem der geciteerde bronnen. Om technische redenen is daarin soms nog vereenvoudiging aangebracht. 
J. Wils - 978-90-04-28634-4 Downloaded from Brill. come4/26/2023 03:02:58PM via free access 


\section{INLEIDING.}

(Man) ... pflegt nicht von Sprachwissenschaft schlechtweg, sondern von allgemeiner Sprachwissenschaft $z \mathfrak{u}$ sprechen, und man mag es tun, nur darf man ihr nicht besondere Sprachwissenschaften gegenüberstellen; sie flieszt mit ihnen zusammen oder, wenn man will, deckt sich mit ihnen.

H. Schuchardt.

Het debat omtrent de aard van het indonesische werkwoord, en met name de vraag of de typische conjugatievorm hier als "passief" dan wel als actief dient te worden opgevat, is thans bijna een eeuw oud. Niet alleen de specialisten van het terrein, maar ook grote comparatisten als C. C. Uhlenbeck, Schuchardt, Trombetti hebben aan de besprekingen deelgenomen. Een oplossing van het probleem die alle partijen bevredigt, is echter tot nu toe nog niet gevonden. Activisten en passivisten, of „radicalen” en ,traditionalisten”, zoals Kiliaan zeide, staan thans in de grond nog juist zo tegenover elkaar als b.v. in de dagen van Tendeloo, Fokker en Van Ophuysen.

Achteraf bezien, kan men dit trage verloop van zaken zeker ook wel begrijpen. Hoe men de zaken ook wendt of keert, de analyse van het indonesische werkwoord is een moeilijke en veelomvattende opgave. En dit niet alleen omdat de feiten op zichzelf reeds zo talrijk en gecompliceerd zijn, maar vooral omdat men er niet in slaagt de juiste criteria te vinden waarnaar deze dienen te worden geordend. Het overzicht en de synthese blijven daardoor op zijn best gebrekkig. Zoals zo vaak in dergelijke gevallen, schuilt het eigenlijke klemmende punt m.a.w. eerder in de begrippen dan in de zakelijke gegevens zelf.

Zo komen b.v. in de indonesische talen, alles bijeengenomen, zeker niet minder dan zeven of acht totaal verschillende conjugatietypen voor, die elk telkens weer hun eigen subtypen en varianten vertonen. In de tidongdialecten, het sawoe, batan, ngad'a is b.v. het werkwoord geheel ,vormeloos”, zoals men wel zegt in de algemene taalwetenschap; 
d.w.z. de verbale grondstam blijft nu door alle personen, tijden en wijzen heen eenvoudig onveranderd. Daarnaast staan echter ook talen waarin elke persoon, althans in bepaalde omstandigheden, regelmatig over eigen vormen beschikt om de steller der handeling aan te duiden. Dit is dus juist het omgekeerde type van zoëven; de persoonsconjugatie is nu volledig. En tussen deze beide extremen in staan dan gevallen waarin eenzelfde taal zowel ,veranderlijke” ( = conjugabele) als „onveranderlijke" (= niet-conjugabele) vormen naast elkander herbergt (rottinees). Vanwaar opeens deze opvallende rijkdom, zo vraagt men zich af, en dit in een taalgroep die op andere punten zo weinig variatie in haar vormgeving kent? En welk van de drie genoemde typen is nu oorspronkelijk: het vormeloze werkwoord, of het totaal-, resp. het partieel conjugerende?

Een tweede, sterk vertakte isoglos die door bijna geheel het materiaal loopt, betreft de aard der conjugatietekens die aan het werkwoord worden gehecht. In talen als minangkabau, bimanees, sumba heeft men duidelijke voorbeelden van de z.g. possessieve flectie, d.w.z. dat de agensaanduiding nu geheel samenvalt met die van de bezitter bij het nomen. Bima $k u$-lao(-ra) enz. ,ik ga" maar ook ana-ku ,mijn kind”; $m u-l a o(-r a)$ "jij gaat" naast ana-mu ,,jouw kind"; na-lao(-ra) ,hij gaat” naast ana-na „zijn kind” enz. In andere talen echter is de subjectsrij volkomen zelfstandig. Iedereen is het er over eens, dat men in het laatste geval een vorm van werkelijke verbale flectie voor zich heeft. Maar is ook de possessieve flectie een vorm van flectie? Of zijn constructies als bima $k u$-lao(-ra) eerder nominaal van karakter? Zou men hier moeten vertalen „mijn gang”; mu-lao(-ra) ,jouw gang” enz.? Vrijwel algemeen worden de laatste vragen in de indonesische vakliteratuur bevestigend beantwoord. De verhouding van de possessieve flectietypen tot de andere is echter nooit systematisch onderzocht, en een nadere overweging zou dus wel wenselijk zijn.

Wat de plaats der conjugatietekens betreft, kan men in de archipel tussen prefixtalen en suffixtalen onderscheiden. Verreweg de meeste nadruk valt gewoonlijk op de prefixtalen. De suffigering komt ook inderdaad minder voor, en is zeer variabel van vorm. In het rottinees houdt Prof. Jonker het z.g. enclitische (= suffigerende) verbale type zelfs voor uitstervend.

Van het boeginees, het makassaars waarin analoge formaties voorkomen, kan men ditzelfde in ieder geval echter niet zeggen. 
Ook de z.g. substantief-constructie, die vooral in de centrale delen van de groep verspreid is (bare'e) en die, naar Dr. Esser zeer goed gezien heeft, onmogelijk van de ,gewone” conjugatievormen gescheiden kan worden, suffigeert regelmatig de persoonsindices en is volop levend in het taalsysteem. Er is dus gèèn reden de suffixflectie te verwaarlozen, al was het alleen maar, omdat deze misschien ook een brug vormt naar de drukbesproken conjugatievorm van enkele der meest westelijke talen, waar - althans in bepaalde personen - zowel prefixen als suffixen naast elkander kunnen voorkomen. Maleis di-lihat-na „hij ziet, door hem wordt gezien" naast $k u$-lihat ,ik zie, door mij wordt gezien"; gajo $i$-bli-ko ,,jij koopt” naast $k u$-bli ,,ik koop” enz.

Een andere typische merkwaardigheid van de taalkaart der indonesische conjugatievormen, die toch eveneens om verklaring vraagt, bestaat nog in het gemis aan geographische samenhang tussen de verschillende vormtypen. Soms heeft eenzelfde type weliswaar een groter natuurlijk landschap of een aaneengesloten reeks eilanden in beslag genomen, maar daartegenover staan ook gevallen waarin men bijna de indruk krijgt, alsof juist de scherpste tegenstellingen elkander het meest hebben aangetrokken. Zo is het werkwoord op Sawoe en Buru (Màserète) „vormeloos”, maar het naburige soembanees, resp. de dialecten van Ambon, vervoegen even regelmatig alle werkwoorden die ze bezitten. Op Midden-Timor zijn het alleen de meer naar het binnenland gelegen dialecten van het tettum, die regelmatig de conjugatie bij de met ha-gevormde "causativa" toepassen, de kustdialecten vertonen volstrekt niet dezelfde „correç̧ão” op dit punt, deelt da Silva mee. En zo zijn er nog allerlei andere dergelijke gevallen meer. Eenvormig en monolineair, zo mag men uit dergelijke feiten wel concluderen, is de geschiedenis van het indonesische conjugatiestelsel blijkbaar niet!

En het meest verrassende punt is wel, dat tegenover al deze verschillen en nuances, die telkens en telkens weer de morphologische en geographische continuiteit van de archipel verbreken, ineens de omstandigheid staat dat de uiterlijke vorm der subjectstekens over het gehele gebied, in hoofdtrekken althans, vrijwel constant is. Juist deze conclusie is het voornaamste resultaat van Jonker's uitvoerige studie Over de ,vervoegde" werkwoordsvormen in de maleis-polynesische talen, BTLV 65 (1911), 266 vv. Dr. R. Haaksma, die zoveel later het inmiddels sterk toegenomen materiaal bestudeerde, heeft op dit punt 
slechts de conclusie van zijn voorganger kunnen bevestigen ${ }^{1}$ ). Hoezeer de aard der conjugatie dus ook verschilt taal voor taal, de persoonsuitgangen waarmede de agens wordt aangeduid blijven overal ongeveer dezelfde. Weliswaar treden hier en daar wisselvormen op, en soms is ook de inslag voelbaar van speciale, meer locale systemen (zoals b.v. in de talen van Borneo), maar door de wirwar van al dergelijke gemakkelijk te verklaren variaties heen kan men toch duidelijk overal hetzelfde grondparadigma van elementen blijven onderscheiden. Voor de beide eerste personen luiden de tekens:

S. $1 k u ; 2 m u, n u$; PL. 1 excl. $m i$, $m a$; incl. $t a ; 2 m i$.

Zo stapelt zich bij de studie van het indonesische werkwoord dus als het ware de ene moeilijkheid op de andere. Waar de verwarde knoop het eerst aan te vatten? Hoe begrijpelijk daarom ook dat zich reeds heel wat debatten rond dit thema geconcentreerd hebben! Zonder overdrijving kan men zeggen, dat het werkwoord reeds vrijwel vanaf het begin der vergelijkende studies op dit terrein het centrum heeft gevormd van alle dieper reikende beschouwingen.

Alle druk besproken questieuze punten systematisch nagaan heeft voor ons doel geen zin. Vele van de vroegere analysen hebben thans daarenboven nog slechts historische waarde. Voor het historische overzicht verwijzen wij dus naar de studies van Tendeloo, Haaksma en Emeis ${ }^{2}$ ). Alleen over enkele der meer recente opinies zullen we, ter algemene oriëntatie, nog kort refereren.

Allereerst dient daarbij de theorie van Prof. Jonker te worden genoemd, omdat deze zo systematisch is opgebouwd, en reeds sinds geruime tijd, direct of indirect, het debat beheerst. Jonker neemt dan aan in het zoëven geciteerde artikel, dat de persoonsconjugatie reeds in de oerindonesische grondtaal werd toegepast, en wel bij alle verbale typen zonder onderscheid. Het verlies van de conjugatie, resp. de beperking daarvan tot speciale kategorieën als b.v. de transitiva, is z.i. secundair. Het karakter der vervoegde vormen was naar zijn mening oorspronkelijk actief, en tot op heden is dit in sommige talen nog zo.

Dr. S. J. Esser daarentegen meent, dat de oudste vervoegde vormen

1) R. Haaksma, Inleiding tot de studie der vervoegde vormen in de indonesische talen. Diss. Leiden 1933.

2) H. Tendeloo, Maleische grammatica, Leiden 1901; dl II, 168-240; R. Haaksma, Inleiding op. cit., XIII vv.; M. G. Emeis, Vorm en functie in klassiek en modern maleisch, Utrecht $1945 ; 159-164$. 
alleen bij de transitiva thuishoorden en passief van nuance waren. Thans echter is een ontwikkeling in actieve richting gaande, ,op welken ontwikkelingsweg de eene taal verder de andere minder ver is voortgeschreden" ${ }^{3}$ ). Haaksma's grondidee schijnt te zijn, dat de veel besproken dubbel geaffigeerde vormen van het maleis etc. (type di-lihat$\tilde{n} a$ ) oorspronkelijk mediaal-reflexieve (intransitieve) betekenis hadden. Later kan zich daaruit gemakkelijk een half-passieve nuance hebben ontwikkeld. De meer-oostelijke talen van de archipel hebben alle tekens van het dubbele type echter weer verloren, en bezigen thans bij de vervoeging nog alleen proclitische elementen ${ }^{4}$ ).

Men ziet het, „tot capita tot sensus”! Zondert men de gedachte uit, dat de persoonsconjugatie reeds een oeroud indonesisch bezit is, dan is er op alle gewichtige punten tussen deze drie auteurs flagrante tegenspraak....

Wat onze eigen bedoeling aangaat, deze is niet alle zijden van het veel-omvattende vraagstuk te bespreken. We willen enkel trachten wat verder te komen op enige punten, die het algemene systeem der verbale ontwikkeling raken. Het eerste hoofdargument zal daarbij zijn een enigszins andere opvatting omtrent de herkomst der verbale subjectstekens als tot nu toe gebruikelijk is. Langs deze „rode” draad zullen we verder in het hart van het probleem trachten in te dringen.

3) S. J. Esser, Nogmaals de vervoegde vormen. Feestbundel van het Koninklijk Bataviaasch Genootschap van Kunsten en Wetenschappen I (1929), 161 vv.

4) R. Haaksma, Inleiding op. cit., 176 vv. 


\title{
EERSTE DEEL.
}

\section{HET PRONOMINAAL SYSTEEM DER INDONESISCHE TALEN.}

\author{
HOOFDSTUK I.
}

\section{De structuur van het pronominaal systeem.}

We hebben hierboven reeds de vormen der oerindonesische conjugatietekens geciteerd, zoals Prof. Jonker die gereconstrueerd heeft. Sinds de bevestiging van zijn analyse door Haaksma, vormt dit paradigma één van de meest zekere punten uit de overigens zo duistere voorgeschiedenis der indonesische talen. Welke plaats nemen de subjectstekens nu echter in temidden van geheel het pronominaal systeem? Hoe is de verhouding tot de andere rijen? Bestaat hier verband? En zo ja, hoe valt dit dan te verklaren? Ziedaar de vragen, waarop we in dit hoofdstuk zullen trachten het antwoord te vinden.

$\mathrm{Nu}$ is er van de ontwikkeling en de structuur van het indonesische pronominale systeem helaas niet veel bekend. Het stelsel is misschien een van de rijkste, die de talenwereld kent. Bijna alle ,gewone" vormenrijen kunnen hier in twee of meer verschillende typen voorkomen, maar de studie heeft zich nog niet in deze richting bewogen. Het best blijkt de achterstand wellicht uit de merkwaardige benamingen, waarmede de verschillende kategorieën gewoonlijk in de grammatica's worden aangeduid. Meestal wordt enkel tussen „lange” en ,korte” vormen onderscheiden, waarbij min of meer de gedachte voorzit dat de laatste uit de eerste zijn verkort of afgeleid. Als ,lang” gelden de zelfstandig gebruikte personalia, „kort” zijn daarentegen zowel de possessieve suffixen der nomina als de verbale subjectstekens. Commentaar of nader bewijs wordt aan de determinering verder niet toegevoegd. Deze geldt als ,luce clarius'. Bijzonder expliciet is in dit opzicht b.v. Fr. Müller, die de possessieve tekens reeds in 1882, in een der eerste bredere overzichten dus die er van de indonesische talen werden ge- 
geven, eenvoudig als ,abgekürzte Pronominal-Formen” voorstelt. Juist zo enkele pagina's vroeger: „Die Pronominal-Suffixe, welche den.... malayischen (=indonesischen) Sprachen zukommen.... sind aus den Stämmen der selbständig vorkommenden Pronomina abgeleitet" ${ }^{5}$ ).

Op de naburige verwante terreinen keert juist dezelfde indeling met juist dezelfde benamingen weer terug. Ook Codrington en Ray onderscheiden in de melanesische en polynesische talen bijv. slechts twee pronominale typen, „long forms" en „short forms" ${ }^{6}$ ). Ja, zelfs in de moderne comparatie heeft dezelfde gedachtengang soms wortel geschoten. Zo is b.v. W. Schmidt bij zijn studies, als vanzelf, steeds geneigd de kortere pronominale vormen als reductieproducten van de langere te beschouwen, ook al heeft hij zich nergens met even zoveel woorden over de verhouding van de possessieve en de zelfstandige kategorieën uitgesproken ${ }^{7}$ ). Het hoogtepunt van onzekerheid in dit opzicht vindt men echter wel bij Haaksma, die in zijn zoëven reeds vermelde dissertatie eenvoudig alle typen van pronominale elementen, totaal ongeacht hun functie, met elkander in verband brengt. Alienabile en inalienabile tekens, proclitische en enclitische, zelfstandige en niet-zelfstandige indices, - alles staat voor hem op één $\operatorname{lijn}^{8}$ ).

Alleen Thalheimer was in dit opzicht voorzichtiger. Behalve met de vorm hield hij regelmatig ook rekening met de betekenis en het kategoriale verband der tekens. In zijn boek over de micronesische talen worden daarom de personale en de possessieve vormen van verschillende typen systematisch van elkander gescheiden gehouden, en zelfs aan het slot, bij het opmaken van de eindrekening, niet of nauwelijks met elkander in verband gebracht ${ }^{9}$ ).

5) Fr. Müller, Grundrisz der Sprachwissenschaft II, 2, 122; 77.

6) R. H. Codrington, The melanesian languages, Oxford 1885; 110 vv.; 125 vv. S. H. Ray, A comparative study of the melanesian island languages 65 vv., $68 \mathrm{v}$.

7) W. Schmidt, Ueber das Verhältnis der melanesischen Sprachen zu den polynesischen und untereinander, SBAWW Bd. 141 (1899), 14; -, Die JabimSprache und ihre Stellung innerhalb der melanesischen Sprachen, ibid. Bd. 143 (1900), 36; - Die sprachlichen Verhältnisse von Deutsch-Neu-Guinea, ZAO(O)S Bd. 5, 6 (1900-'01), 13 vv.

8) R. Haaksma, Inleiding op. cit., passim.

9) A. Thalheimer, Beiträge zur Kenntnis der pronomina personalia und possessiva der Sprachen Mikronesiens, Stuttgart 1908. Zie ook H. Frei, Systèmes de deictiques, Acta Linguistica 4 (1944), 111; M. Leenhardt, Langues et dialectes de l'Austro-Mélanesie, Paris 1946, XXVI-XXXIII. 
$\mathrm{Nu}$ dient men zeker toe te geven, dat de traditionele benamingen de algemene indruk vóór hebben. Wat is er gemakkelijker dan een subjectsteken als $1 \mathrm{sg}$. $k u$ af te leiden van het corresponderende personale $a k u$ ? Juist zo kan 2 sg. mu<kamu; 2 pl. mi<kami; 1 pl. $t a<$ kita enz. Maar de analyse blijft dan toch slechts partieel en op contemporain niveau. De betekenis daarvan is dus niet beslissend. Of hebben sommige auteurs zich, bewust of onbewust, ook laten leiden door de parallel der moderne europese talen, waar tussen de verbale subjectstekens en de zelfstandige personalia in het geheel geen onderscheid bestaat? De beide indonesische kategorieën vallen hier eenvoudig samen. Ik roep. Wie roept daar? Ik. Maar ieder weet dat deze ontwikkeling jong is. En in andere talen is de verhouding ook geheel anders.

De conclusie is duidelijk. De tot nu toe bestaande nomenclatuur is, zoals de zaken er thans voor staan, niet voldoende gefundeerd. Er is geen reden om de zelfstandige personalia der indonesische talen a priori als het oorsprongsland van alle overige ,korte” kategorieën te beschouwen, zelfs niet als men zich enkel tot de morphologische analyse beperkt. Wie in dit opzicht zekerheid wenst te hebben, dient de gewone veilige methode te volgen, waarvan reeds Thalheimer het voorbeeld heeft gegeven. Men zal eerst alle voorkomende pronominale kategorieën afzonderlijk dienen te behandelen. En blijkt het daarna nodig of mogelijk, op grond der gevonden oervormen, verschillende van deze nauwer met elkander in verband te brengen, dan kan dit altijd nog geschieden. Wie anders handelt, verwaarloost de functie en de betekenis der grammaticale tekens, d.w.z. juist dat deel van hun wezen dat deze maakt tot wat ze zijn. Haaksma's overigens zeer systematische comparatie zal dus in dit opzicht moeten worden aangevuld. Pas dan krijgt de beschouwing voldoende relief en diepgang.

We beperken ons voorlopig tot de kategorieën der verbale subjectstekens en der possessieve elementen, en geven verder ook slechts zoveel van de overvloed der feiten als nodig is om de gang der redenering duidelijk te maken. Voor alle overige details zij eens en voorgoed naar Haaksma's Inleiding verwezen. 


\section{HOOFDSTUK II.}

\section{De oorsprong der verbale subjectstekens.}

A. Allereerst dan het stelsel der verbale conjugatieprefixen. De oervormen daarvan zijn hierboven reeds afgedrukt. Gaat men de huidige tekens na, dan blijkt hoe het paradigma $*_{k u} ; *_{m u} ; *_{n a}$ etc. niet lang bewaard gebleven is. Secundair hebben allerlei invloeden daarop ingewerkt. Bijzondere locale systemen hebben zich doen gelden, er zijn speciale innovaties geweest, etc. Maar vooral heeft hier blijkbaar ook sterk de aantrekkingskracht van het naburige systeem der zelfstandige personalia gewerkt, met name in het gebied der meer westelijk gesproken talen van groter verspreidingsgebied (gajo, minangkabau, maleis, lampong, boesang). Herhaaldelijk zijn van daaruit langere vormen ingedrongen. Men zie de tabel.

\begin{tabular}{|c|c|c|c|c|c|c|}
\hline \multirow{2}{*}{ gajo } & $\begin{array}{l}\text { verbaal } \\
\text { prefix }\end{array}$ & $1 \mathrm{ku}-, \mathrm{k}-$ & $2 \mathrm{i} \ldots \mathrm{kō}$ & incl. 1 kitö- & excl. 1 kami- & pl. $2 \mathrm{i} \ldots$ kam \\
\hline & $\begin{array}{l}\text { zelfstand. } \\
\text { personale }\end{array}$ & aku & kō & kitö & kami & kam \\
\hline \multirow{2}{*}{ maleis } & $\begin{array}{l}\text { verbaal } \\
\text { prefix }\end{array}$ & $1 \mathrm{ku}-$ & kamu-, kau- & incl. 1 kita- & excl. 1 kami- & pl. 2 kamu- \\
\hline & $\begin{array}{l}\text { zelfstand. } \\
\text { personale }\end{array}$ & aku & kamu & kita & kami & kamu \\
\hline
\end{tabular}

B. Bij de possessieve tekens, die enkel als suffix voorkomen, moet het materiaal onmiddellijk worden gesplitst, omdat men hier voor een dubbel systeem staat. In het uiterste oosten van het gebied komt in een aantal talen n.l. een speciale groep tekens voor, die enkel aan bepaalde groepen van nomina, als de namen van lichaamsdelen, de verwantschapsnamen, en nog enkele andere verwante kategorieën, kunnen worden toegevoegd. Geurtjens en Drabbe spreken daarbij van ,betrekkelijkheidswoorden" of "betrekkings-zelfstandige naamwoorden”; Tauern gebruikt voor de dialecten van Seran "Teilworte”. Ieder die het prachtige artikel van Lévy-Bruhl over het analoge verschijnsel in de melanesische talen heeft gelezen, zal er echter niet aan twijfelen of 
het gaat hier in de grond over het onderscheid tussen de ,alienabile” en de ,inalienabile possessie" ${ }^{10}$ ).

In de meer westelijke talen kent men dit onderscheid in ieder geval niet. De possessieve suffixen hebben hier de ,gewone" genitivische betekenis, en kunnen aan alle nomina zonder onderscheid worden toegevoegd. Ook in het Oosten is dit soms trouwens het geval; blijkbaar waar het gevoel voor beide vormen van possessie verloren is gegaan. We zullen eerst het oorspronkelijke oostelijke stelsel behandelen.

\begin{tabular}{|c|c|c|c|c|c|c|}
\hline & timor & slaroe & fordata & kei & paulohi & boeli \\
\hline 1 & $\mathrm{k}$ & $\mathrm{ku}$ & $\dot{\mathrm{n}}$ & $\dot{\mathrm{n}}$ & $\mathbf{u}$ & k \\
\hline 2 & $\mathrm{~m}$ & $\mathrm{mu}$ & $\mathrm{m}$ & $\mathrm{m}$ & $\mathrm{m}, \mathrm{mu}$ & $\mathrm{m}$ \\
\hline 3 & $\mathrm{n}$ & $\mathrm{n}, \mathrm{ni}$ & $\mathrm{n}$ & $\mathrm{n}$ & $\mathrm{ni}, \mathrm{i}$ & - \\
\hline incl. 1 & $\int k$ & $\int t$ & $\int \mathrm{d}$, dida & $\int d$ & $\int \mathrm{ka}$ & $\int r$ \\
\hline excl. 1 & ?m? & ( mi & ( m, mami & b & ? ma & ( mam \\
\hline 2 & $\mathrm{~m}$ ? & $\mathrm{mi}$ & b, bir & b & ni & meu \\
\hline 3 & $\mathbf{k}$ & $t$ & $r$, rir & $\mathbf{r}$ & si, ni & $\mathrm{ri}$ \\
\hline
\end{tabular}

De vergelijking van de inalienabile tekens levert weinig moeilijkheden

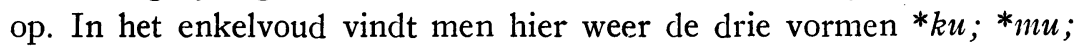
$*_{n i}$ (nevenvormen van $*_{n a}$ ) terug, die reeds Codrington, W. Schmidt, Thalheimer en Ray in juist dezelfde functie in de melanisch-micronesische talen hebben aangetroffen. Men heeft hier dus waarschijnlijk oeroud austronesisch erfgoed voor zich ${ }^{11}$ ). Soms is in de auslaut alleen de vocaal weggevallen; in het paulohi in de eerste en derde persoon daarentegen de consonant. Fordata en kei 1 sg. $\dot{n}$ stamt uit een geprenasaleerde vorm die het teken uitdrukkelijk als genitief kenmerkt; $\dot{n}<\dot{n} k u<n-k u$.

\footnotetext{
10) H. Geurtjens, Spraakleer der keieesche taal, VBG 63 (1921), 20; P. Drabbe, Spraakleer der Fordaatsche taal, VBG 67 (1926), eerste stuk 22; -, Spraakkunst der Jamdeensche taal, ibid. tweede stuk, 33; O. Tauern, Beitrag zur Kenntnis der Sprachen und Dialekte von Seran, Anthropos 23 (1928), 1000-20; 24 (1929), 953-81 ; 25 (1930), 567-78 ; 26 (1931), 109-39; L. Lévy-Bruhl, L'expression de la possession dans les langues mélanésiennes, MSL 19 (1916), 96 vv.

11) R. H. Codrington, The melanesian languages 127; W. Schmidt, Ueber das Verhältnis der melanesischen Sprachen zu den polynesischen und untereinander, SBAWW 141 (1899), 14; S. H. Ray, The melanesian possessives, American Anthropologist 1919, 360; - A comparative study of the melanesian island languages, 69.
} 
In het meervoud zijn de verhoudingen iets meer ingewikkeld. En dit is wel te begrijpen ook. In de meeste van deze oostelijke talen kan men immers aan het nomen, dat reeds van het inalienabel suffix is voorzien, ter versterking óók nog het corresponderende personale of het possessiefteken dat in algemeen gebruik is, voorvoegen. In het timorees is deze toevoeging zelfs verplicht; au mata- $k$, in mata-n: „,mijn (zijn) oog”. In het meervoud zijn de suffixvormen nu blijkbaar op deze wijze onder invloed geraakt van de als gelijkwaardig gevoelde voorgevoegde tekens.

De kortere vormen zijn ook achter het nomen door langere vervangen. Duidelijk kan men in de tabel volgen, hoe het proces zich heeft voltrokken. In het fordata staan de beide rijen reeds als gelijkwaardig naast elkaar; $-d,-m$ enz. zijn de oude tekens; dida, mami enz. zijn niets dan de zelfstandige possessiva. In het jamdena, waarvan de vormen hier niet zijn opgenomen, is men al een stap verder. Het zijn alleen de zelfstandige possessiva die nu in het meervoud dienst kunnen doen (1-nind; -mami; 2- mir; 3- nir). De distinctie tussen de alienabile en de inalienabile kategorieën is daarmee in deze personen dus practisch geheel opgelost. Ook boeli 2 pl. - -meu (voor miu) is niets anders dan een personale.

Timorees incl. $1-k$ staat in de plaats van $-t$, evenals $3 \mathrm{pl}$. $-k$ in de plaats van $-\boldsymbol{n}$. Deze wisselingen staan in verband met de typische kwestie der ,,anorganische eindconsonanten" in deze taal, waarover we nog uitvoerig zullen moeten spreken (52 vv.). Paulohi incl. $1-k a$ is uit $-n t a$, volgens E. Stresemann, Die Lauterscheinungen in den ambonischen Sprachen $\S 134-136$. In excl. 1 en 2 pl. staat kei $-b<b i$ weer naast $-m i$; hetzelfde geldt voor fordata $2 \mathrm{pl}$. $-b$. Paulohi $3 \mathrm{pl}$. $-n i$ is een innovatie; de vorm dient enkel voor het neutrum en staat buiten het eigenlijk systeem.

Alles bijeengenomen luidt het resultaat der reconstructie dus:

S 1 ku; 2 mu; 3 ni, na; P1. 1 incl. ta; excl. ma, mi; $2 m i ; 3$ ri, ra.

C. Voor het westelijk systeem moge het bijgaand globaal overzicht dienst doen. (Zie pag. 12).

De grondvorm in de eerste persoon singularis is weer $*_{-} k u$. Naar gelang de omstandigheden kan dit teken worden verkort resp. tot $-k$ of $-u$; nias $-g u<\dot{n} k u$ evenals rotti $-\dot{n}$ met de reeds bekende prenasalering voor de genitief. De tweede persoon vertoont -*mu; -*nu; dit element is vrij constant en zeer ver verspreid.

In de derde persoon enkel- en meervoud is de rijkdom aan tekens veel 
groter; -na is voor het enkelvoud echter één van de meest voorkomende elementen. Een nevenvorm daarvan is -ni, dat b.v. in het lampongs voorkomt ; maleis $-\tilde{n} a<-n i-a$, waarin de laatste vocaal een versterkend element is, zoals men dit in dezelfde taal ook antreft in het corresponderende zelfstandige personale $i a<i$ - $a$.

In het meervoud komen in de verschillende talen goeddeels dezelfde

\begin{tabular}{|c|c|c|c|c|c|c|c|}
\hline & maleis & nias & oud-jav. & makass. & biman. & rottin & oer-indones. \\
\hline 1 & ku & gu & $\mathrm{ku}, \dot{n} \mathrm{ku}$ & $\mathrm{ku}$ & $\mathrm{ku}, \mathrm{k}$ & $\dot{\mathrm{n}}, \mathbf{k}$ & $* k u$ \\
\hline 2 & $\mathrm{mu}$ & $\mathfrak{u}, \mathrm{mõ}$ & $\mathrm{mu}, \tilde{\mathbf{n} u}$ & $\mathrm{nu}$ & $\mathrm{mu}, \mathrm{m}$ & $\mathrm{m}$ & $*_{\mathrm{mu}} ; *_{\mathrm{nu}}$ \\
\hline 3 & ña & nia & ก̃a & na & na, $n$ & $\mathrm{n}$ & $*_{\text {na }} ; *_{\text {ni }}$ \\
\hline incl. 1 & $\int$ kita & $\int d a$ & $\int$ ta, nta, nda & & $\int \mathrm{ta}, \mathrm{t}$ & $t$ & $*_{\text {ta }}$ \\
\hline excl. 1 & $\{$ kami & $\{\mathrm{ma}$ & $\{\mathrm{mi}, \mathrm{mami}$ & & $\mathrm{ku}$ & $\mathrm{m}$ & $*_{\mathrm{mi}} ; *_{\mathrm{ma}}$ \\
\hline 2 & $\mathrm{mu}$ & $\mathrm{mi}$ & $\mathrm{mu}$ & $\mathrm{mu}$ & $\mathrm{mu}$ & $\mathrm{m}$ & ${ }^{*} \mathrm{mi} ;{ }^{*} \mathrm{mu} ;{ }^{*} \mathrm{nu}$ \\
\hline 3 & กิa & $\mathrm{ra}$ & $\tilde{\text { na }}$ & na & na & $\mathbf{n}$ & ${ }^{*}$ na $;{ }^{*} \mathrm{ni} ;{ }^{*} \mathrm{ra} ;{ }^{*} \mathrm{ri}$ \\
\hline
\end{tabular}

tekens voor. In een deel van de Ambon-Timorgroep daarentegen, waar men eveneens een aantal possessieve tekens vindt, die het onderscheid tussen de alienabile en inalienabile kategorie niet meer kennen, zoals we reeds hebben vermeld (10), heeft het plurale een typische $r$-vorm, die weer uit het zelfstandige personale schijnt te stammen (fordata, kei 3 pl. -rir).

In de eerste persoon inclusivus luidt de oervorm $* t a$, dat weer tot $-t$ kan worden verkort, resp. geprenasaleerd tot $-n t a$ of $-n d a$; ook nias $-d a<-n t a$. De meest variabele vorm van het gehele stelsel is de eerste persoon exclusief. De grondvorm schijnt hier zowel $*_{m i}$ als $* m a$ te zijn geweest. De tekens hebben zich volgens W. Schmidt ook spoedig verbonden tot *mami, van waaruit b.v. vormen als mentawai mai, simaloerees mại te verklaren zijn. Waarschijnlijk is $*_{m i}$ hier, zoals geheel in de speciale betekenis past, hetzelfde element als ook in de tweede persoon voorkomt. In de tweede persoon meervoud is de oorsprong *miu, waaruit door verkorting resp. $*_{m i}$ en $*_{m u}$ ontstaan is. Men vindt de diphthongische vorm b.v. nog in mentawai -mui, mori -miu. Over de $b$-variant is hierboven reeds gesproken bij enkele analoge vormen uit het fordata en het kei (11).

Dat men ook bij dit type suffixen weer rekening moet houden met 
een vrij sterke secundaire invloed van de zelfstandige personalia, blijkt b.v. uit maleise vormen als kita; kami; het geciteerde -rir uit het fordata en het kei enz.

Alles bijeengenomen luidt dus ook hier het resultaat:

$\mathrm{S} 1 k u$; $2 m u, n u ; 3 n i, n a$; P1. 1 incl. ta; excl. $m a, m i ; 2 m i, m u, n u$; 3 na, ni, ra, ri.

We kunnen het voor ons doel bij deze enkele groepen van feiten laten. Staan we thans een ogenblik stil, en maken we de rekening op. Welk saldo heeft de vernieuwde vergelijking der pronominale vormen ons nu opgeleverd? Een grote verrassing, mag men wel zeggen! De traditionele Assepoestersrol voor de verbale subjectstekens, waarvan we zijn uitgegaan, is inderdaad niet passend. Men kan vormen als $1 \mathrm{ku} ; 2 \mathrm{mu}$ onmogelijk zonder meer als "korte" varianten naast de corresponderende ,lange" personalia $1 a k u ; 2$ kamu, etc. plaatsen. Hoe vlot de moderne analyse in dit opzicht ook verloopt, van de werkelijke genetische verhoudingen geeft ze een totaal verkeerde indruk. Dat de subjectstekens secundair zeer sterk door de personalia zijn beinvloed, dient men zeker toe te geven. Dit is het korreltje waarheid dat in het vroegere misverstand was verborgen. Maar dit verband behoort tot de periode der individuele taalgeschiedenissen, en is niet oerindonesisch. Maar er is meer. Voor de in ere herstelde Assepoester zijn tegelijk ook nieuwe verwanten gevonden. Het door Jonker gereconstrueerde paradigma ${ }^{*} k u ;{ }^{*} m u ;{ }^{*} n a$ enz. stelt, naar uitvoerig gebleken is, niet alleen de oervormen der subjectstekens voor, maar tevens ook die der inalienabele elementen uit het Oosten en der algemene genitivische suffixen uit het Westen. Op de een of andere wijze moet er tussen deze kategorieën dus wel een bijzondere relatie bestaan. Hier ligt een knoop in het pronominale stramien, die men tot nu toe teveel over het hoofd heeft gezien.

Of om de beide feiten nog eens in Fr. Müller's formulering samen te vatten: Naar de vorm gezien, behoort de oer-indonesische conjugatie niet tot het logificerende "praedicatieve" type maar tot het zoveel eenvoudiger ,possessieve” type ${ }^{\mathbf{1 2}}$ ). En talen als minangkabau, bimanees, etc., waarin tot nu toe nog steeds de subjectstekens geheel samenvallen met de possessieve elementen, vormen dus geen uitzondering op de algemene indonesische regel, zoals men wellicht zou menen op het eerste gezicht. $Z_{\mathrm{ij}}$ hebben integendeel, op welke wijze dan ook, juist het oorspronkelijke vormtype het best bewaard.

12) R. Haaksma, Inleiding 178. 


\section{HOOFDSTUK III.}

\section{De „knoop” in het pronominale systeem.}

De geschiedenis van het indonesische pronominale systeem is blijkbaar meer ingewikkeld, dan gewoonlijk wordt aangenomen. En de voornaamste vraag voor ons doel is nu maar, hoe de rij der subjectstekens zich precies verhoudt tot de beide nieuw gevonden verwanten? Hoe is de beschreven „knoop” in het pronominale stelsel m.a.w. ontstaan? Is de possessieve streng hier de oudste? Of juist omgekeerd die der conjugatie-elementen? Eén punt staat in ieder geval onmiddellijk vast. De bewijskracht van het indonesische materiaal is uitgeput. Daarmede alleen zullen we niet in staat zijn op de gestelde vragen antwoord te geven. Daaraan is de tot nu toe bestaande verwarring juist te danken. Het zal dus zaak zijn elders, en met name in de andere austronesische ondergroepen, hulp te zoeken. Kan een dergelijke verbreding van de vergelijking hier misschien verdieping van inzicht brengen? De taalwetenschap is op deze wijze reeds vaker uit een dreigende impasse gered.

$\mathrm{Nu}$ bestaat er inderdaad alle aanleiding om bij de studie van de indonesische pronominale vormen steeds ook het oog op die der verwante melanesische en polynesische talen gericht te houden. En ook zonder de hierboven op Haaksma's Inleiding uitgeoefende critiek, en wat daarop gevolgd is, zou het nut daarvan zich als van zelf hebben opgedrongen. Een feit is nl., dat Codrington juist dezelfde singulare vormen $1 * k u ; 2 * m u$; $3 *_{n a}$, als Jonker voor de indonesische talen heeft gereconstrueerd, reeds eerder in de melanesische talen had ontdekt. Wij hebben daaraan reeds kort herinnerd ${ }^{13}$ ). Ook in een aantal polynesische talen keren deze elementen terug. Er is dus alle kans, dat we hier in werkelijkheid niet alleen voor oer-indonesisch, maar zelfs voor oer-austronesisch erfgoed staan. Dit is natuurlijk een feit van groot belang. In het meervoud lopen de vormen in de verschillende talen sterker uiteen, en vaste grondelementen zijn hier daarom nog niet gereconstrueerd.

13) cfr. 10, noot 11 . 
De moeilijkheid is alleen, dat dezelfde functionele verwarring, die we zoëven op het indonesisch terrein hebben aangetroffen, zich tot op zekere hoogte nu ook in de austronesische comparatie herhaalt. Vooreerst komt het paradigma $*_{k u} *_{m u}^{*}{ }^{*} n a$ enz. hier en daar ook in de melanesische talen als conjugatietekens voor (Santa Cruz enz.). Maar vooral als possessieve indices is het gebruik daarvan zeer wisselend. We vatten de voornaamste feiten, waarop we hieronder nog herhaaldelijk zullen moeten terugkomen, en die voor het verloop van ons betoog van zeer groot gewicht zijn, kort samen.

In de melanesische talen kunnen $k u ; m u ; n a$ enz. het best als algemene persoonstekens worden gekarakteriseerd. $\mathrm{Zij}$ horen wel speciaal thuis in het verband der beschreven nominale tweedeling, maar of hun betekenis alienabel dan wel inalienabel is, hangt eenvoudig af van de plaats in de constructie. De inalienabile tekens staan als suffixen achter het nomen. De alienabile daarentegen worden daarvóór geplaatst; en wel als aanhangsel achter een speciaal element, dat bij verschillende groepen van nomina telkens andere vormen aanneemt, en dat Codrington de niet bijzonder gelukkige maar moeilijk vervangbare naam van "possessive" heeft gegeven ${ }^{\mathbf{1 4}}$ ). In het pala, de taal van het vroegere Nieuw-Mecklenburg, heeft men b.v. a mata-gu; mata-m; mata- $n$,,mein (dein, sein) Auge” ( $a$ is artikel) ; maar met het „possessive" $a$ voor de namen van spijzen enz. a-gu pas; $a-m$ pas; $a-n a$ pas „mein (dein, sein) Taro" enz.; met het meer algemeen gebruikelijke „possessive” $n u$ b.v. nu-gu mal; nu-m mal; nu-no mal (no < na) "mein (dein, sein) Kleid" (hier alienabel) enz. ${ }^{15}$ ).

In de westelijke indonesische talen kent men geen nominale tweedeling, zoals hierboven reeds kort werd vermeld. $K u$; $m u$; $n a$ enz. treden hier enkel als algemene genitiefuitgangen op. De tekens vinden hun plaats daarbij achter de nominale stam, d.i. dus waar vroeger de inalienabile tekens stonden. In het maleis kan men b.v. evengoed zeggen topi-ku; topi-mu „mijn (jouw) hoed” als anak-ku; anak-mu „mijn (jouw) kind".

Zeer ingewikkeld is verder de toestand in de oostelijke indonesische

14) R. H. Codrington, The melanesian languages, 128.

15) P. Peekel, Grammatik der neu- mecklenburgischen Sprache 59 vv. 
talen. De nominale tweedeling is hier bij een aantal talen nog wel bewaard, en de inalienabile tekens staan hier ook nog op hun oorspronkelijke plaats achter het nomen. De kracht der constructie is echter blijkbaar reeds zozeer afgenomen, dat gewoonlijk het corresponderende personale ter versterking dient toegevoegd. Het alienabel aanduidingsstelsel heeft in dezelfde talen nog meer geleden. De „possessives” zijn vrijwel overal verstard (kisser, fordata), en het oorspronkelijk stelsel der persoonstekens is danig in verval. Ook hier treden trouwens de personalia vaak ter versterking of zelfs ter vervanging van de possessieve tekens op.

Welke functie der tekens is in dit geval nu de oudste, zo kunnen we onze vraag van zoëven slechts herhalen. $\mathrm{Zijn} *_{k u-;}^{*} *_{m u-;}^{*} n a-$ enz. op het austronesische terrein oorspronkelijk possessieve tekens of conjugatie-elementen geweest? Lag het aanvankelijk gebruik hier bij het nomen of bij het verbum? Het gunstige verschil met hierboven is alleen, dat er over de ontwikkelingsgeschiedenis der austronesische kategorieën toch wel meer bekend is, dan over die der indonesische talen. Het terrein is op dit punt veel beter onderzocht. Er zijn vooral twee punten, die voor ons onderzoek van groot gewicht zijn.

Daar is vooreerst de omstandigheid, dat er over de geschiedenis der nominale tweedeling in de austronesische talen onder de deskundigen practisch eenstemmigheid van mening bestaat. W. Schmidt heeft direct reeds in zijn eerste grote studie over dit terrein de melanesische ondergroep als het oorsprongsland van deze belangrijke nominale distinctie aangewezen ${ }^{16}$ ). Thalheimer en Ray hebben deze conclusie later, op grond van hun eigen zelfstandig onderzoek, ten volle bevestigd ${ }^{17}$ ). Zowel de overmatige uitbreiding der nominale klassen, die men in de polynesische talen en soms ook reeds in de micronesische talen vindt, als ook het ontbreken van elke indeling, zoals dit in de westelijke

16) W. Schmidt, Ueber das Verhältnis der melanesischen Sprachen zu den polynesischen und untereinander, op. cit.

17) A. Thalheimer, Beiträge zur Kenntnis der Pronomina personalia und possessiva der Sprachen Mikronesiens, Stuttgart 1908. S. H. Ray, A comparative study of the melanesian island languages, 69. Zie ook hierboven pag. 10, noot 11 . En verder S. H. Ray, The common origin of the oceanic languages, Journal of the Polynesian Society, Vol. 5 (1896), 62. 
indonesische talen voorkomt, zijn secundair in vergelijking met het klaar en scherp getekende twee-klassensysteem in de melanesische talen. De inalienabilia vormen blijkbaar de positieve pendant van het stelsel, maar de alienabilia de negatieve pendant.

Ook op het indonesisch terrein is de situatie in de oostelijke talen, waar men de tweedeling wèl vindt, in de vakliteratuur in ieder geval steeds als een zéér oud gegeven beschouwd.

In een latere periode heeft zich hier echter een belangrijke deflectie voorgedaan ${ }^{18}$ ). Dergelijke feiten doen dus - voorlopig geformuleerd zeker de kansen voor de prioriteit van de nominaal-possessieve streng in de te analyseren knoop stijgen. De indeling der nomina in twee groepen schijnt een oeroud feit te zijn in de austronesische taalgeschiedenis. En ook de latere ontwikkeling der pronominale kategorieën maakt de indruk, daarvan nog de weerslag te hebben ondervonden.

Daarentegen wekt het feit der verbale flectie, en dus ook dat der flectietekens, in het austronesisch verband beschouwd juist de gedachte van een betrekkelijk jonge en oppervlakkige ontrikkeling. Alleen in de westelijke helft der groep, in de indonesische talen dus, is de verbale conjugatie verder verspreid; maar de vormen daarvan zijn taal voor taal zéér verschillend en wisselend. In de meest oostelijke vleugel daarentegen, d.w.z. in de polynesische talen, valt niets van die aard te bekennen. Het werkwoord is hier ,vormeloos". De melanesische talen staan tussen beide extremen in. Vervoegingsverschijnselen zijn hier vrij frequent, maar de gewone regel vormen zij niet.

Zo krijgt men dus, alles bijeengenomen, bij de eerste kennismaking met de feiten wel de indruk, dat de ,knoop” in het austronesische (en dus ook in het indonesische) pronominale stelsel van nominale origine is. Het gebruik van $*_{k u} *_{m u} ; *_{n a}$ enz. als possessief element schijnt ouder te zijn dan dat als vervoegingsteken. Later moet hier op de een of andere wijze een zeer uitgebreide vorm van reïnterpretatie hebben plaats gehad.

18) J. Jonker, Kan men bij de talen van den Indischen Archipel eene Westelijke en eene Oostelijke afdeeling onderscheiden? VAWA, 4e reeks, deel 13 (1914), $314-417$; P. Kanski und P. Kaprusch, Die indonesisch-melanischen Uebergangssprachen auf den kleinen Molukken, Anthropos 26 (1931), 883-90. Zie verder hierachter 19. 
De grote vraag is nu natuurlijk verder maar, of deze eerste impressie zich ook bij nader en meer gedetailleerd onderzoek zal handhaven. Een aantal hypothesen, hoe sluitend en oriënterend misschien ook, bewijst op zichzelf niets. Het zal nodig zijn, al de functionele en semantische overgangen, die daardoor worden geëist, stuk voor stuk, en de facto aan te tonen. Pas daarna is c.q. een geldig bewijs geleverd. We zullen dus hieronder op allerlei punten meer in bijzonderheden moeten treden.

Het is blijkbaar een vrij uitgebreid program, dat ons op deze wijze wacht. Te vermijden valt dit echter niet. Ook in de wetenschap geldt het soms te kiezen of te delen. Men dient de gedachtengang, die door de feiten wordt gewezen, ten einde toe te volgen, wat dit verder ook moge kosten, òf wel te zwijgen. We beginnen met het stelsel der nominale tweedeling, omdat daar de aansluiting bij de vroegere ontwikkeling het eerst gevonden schijnt te kunnen worden, en omdat hier ook reeds de meeste voorstudies zijn verricht. 


\title{
TWEEDE DEEL.
}

\section{HET NOMINAAL SYSTEEM DER INDONESISCHE TALEN.}

\author{
HOOFDSTUK IV.
}

\section{De verhouding der beide possessieve stelsels.}

Welke nominaal systeem is ouder in de indonesische taalgeschiedenis, de uniforme behandeling zoals die in het Westen voorkomt, of de tweedeling die een aantal talen uit het Oosten kenmerkt? En vooral, waarop berust ten slotte de ontwikkeling die hier heeft plaats gehad? Wat betekent in de grond de indeling der nomina in een alienabile en een inalienabile groep?

Er zijn over deze kwestie in de litteratuur twee opvattingen naar voren gekomen, die elkaar op bepaalde punten bevestigen maar op andere ook weer tegenspreken. Prof. Jonker houdt een zekere reductietheorie. Volgens hem stelt de affigering van possessieve tekens bij alle nomina zonder onderscheid, zoals de westelijke talen die toepassen, de oorspronkelijke toestand voor. Later echter verviel deze mogelijkheid, „om welke reden dan ook”, en bleef alleen bestaan bij „,een aantal zaken (die).... in een zekere periode van beschaving.... niet als op-zich-zelf-staande (worden) beschouwd, doch alleen behoorende bij een bepaalde persoon, of als een deel van het geheel" ${ }^{19}$ ). Aldus ontstond wat hierboven de inalienabile kategorie genoemd is.

Ook voor Kanski en Kaprusch is de nominale tweedeling slechts een moment van weinig relief in de indonesische taalhistorie. Dit dankt h.i. zijn oorsprong nl. enkel aan de invloed van het papua-substraat. Aldaar immers was vooropplaatsing van de genitief gebruikelijk; en

19) J. Jonker, Kan men bij de talen van den Indischen Archipel eene Westelijke en eene Oostelijke afdeeling onderscheiden? VAWA 4e reeks, deel 13 (1914), 324 ; -, Rottineesche Spraakkunst, Leiden 1915, 351-354. 
daarom trachtten de onderliggende elementen deze gewoonte ook door te zetten, toen later de austronesische talen over het terrein kwamen gevloeid. $\mathrm{Zij}$ slaagden daarin echter alleen bij de groep der alienabilia, waar de verhoudingen min of meer op die van een genitief geleken. Maar bij de inalienabilia, waarbij in het geheel geen sprake was van een genitivische verhouding, bleef de oud-austronesische postfigering bewaard. Vandaar de huidige tweeledige klassificatie ${ }^{20}$ ). Men zou hier dus van een infiltratie- of aanpassingshypothese kunnen spreken.

We zullen trachten hieronder het gestelde vraagstuk achtereenvolgens van drie zijden te benaderen. Allereerst bestuderen wij (1e) de structuur der inalienabile groepen. Daarna zullen we (2e) het possessieve tekenstelsel zèlf nagaan; om tenslotte met name $(3 e)$ de plaats van de nieuw ontwikkelde genitief in ogenschouw te nemen.

\section{De structuur der inalienabile groepen.}

Eén van de diepste criteria die men groeperingen als die der alienabilia en der inalienabilia kan aanleggen, is haar structuur. Allerlei bijzonderheden over de aard en de graad der ontwikkeling komen op deze wijze voor den dag $^{21}$ ). Berust de nominale tweedeling der oostelijke indonesische talen dus waarlijk op niets dan een vluchtige reductie van een vroegere phase zonder distinctie, zoals Jonker wil; òfwel op

20) P. Kanski und P. Kaprusch, Die indonesisch-melanesischen Uebergangssprachen auf den kleinen Molukken, Anthropos 26 (1931), 883-90.

21) J. Wils, De nominale klassificatie in de afrikaansche negertalen, Diss. Nijmegen 1935. De distinctie tussen de inalienabile en de alienabile possessie is vrij ver verspreid in de talenwereld. Men zie b.v. W. von Humboldt, Einleitung ïber die Verschiedenheit des menschlichen Sprachbaues, Berlin 1836, 181 v.; Fr. Müller, Grundrisz der Sprachwissenschaft I, 2, 149; R. H. Codrington, The melanesian languages, Oxford 1885, 126, 128-133 et passim; H. Steinthal-Misteli, Charakteristik der hauptsächlichsten Typen des Sprachbaues, Berlin 1893, 80, 135; ook 140. A. Fischer, ZDMG 61 (1907), 178 vv; S. Simonyi, Die ungarische Sprache, Straszburg 1907, 260, 311; A. Thalheimer, Beitrag zur Kenntnis der pronomina personalia und possessiva der Sprachen Mikronesiens, Stuttgart 1908, 91 vv. et passim; D. R. Fuchs, Finnisch-ugrische Forschungen Bd. 13 (1913), 8; O. Beke, Keleti Szemle, Bd. 15 (1914_'15), 16; 16 (1915-'16), 264 vv.; L. LévyBruhl, L'expression de la possession dans les langues mélanésiennes, MSLP 19 (1914), 96-104; C. C. Uhlenbeck, Het identificeerend karakter der possessieve flectie in talen van Noord-Amerika, VAWA 5e reeks, tweede deel (1917), 345 vv.; W. Bang, Vom Köktürkischen zum Osmanischen. 4. Durch das Possessivsuffix erweiterte Nominalstämme, Pr. Akad. d. Wiss. Berlin 1921; G. Ferrand, Micronésien; LM 448; J. Deny, Langues mongoles; ibid 227 v.; Th. Baader, Die identifizierende Funktion der Ich-deixis im Indo-europäischen, Heidelberg 1929. 
een oppervlakkige besmetting met taalgewoonten uit het substraat, zoals Kanski en Kaprusch vermoeden, dan is er alle kans dat dit op deze wijze het eerst blijkt. We hebben daarom een onderzoek naar de inalienabile groep ingesteld allereerst in een tweetal melanesische talen, die volgens Kanski en Kaprusch eveneens hun tweedeling enkel aan het papuasubstraat te danken zouden hebben, n.l. de taal van het vroegere NieuwPommeren en het marshall (micronesisch). Daarna zijn ook een aantal indonesische talen onderzocht, nl. de drie Tanimbartalen, jamdena, fordata en slaroe, en verder het paulohi van Seran.

\section{Nieuz-Pommeren.}

In het vroegere nieuw-pommers kunnen alleen de inalienabilia voorkomen met wat Constantini ,persönliche Endungen” noemt ${ }^{22}$ ). Een woord voor ,broer (Bruder)" bestaat hier b.v. niet; men kent slechts tura-gu; tura-m; tura-na ,mein (dein, sein) Bruder” enz.

De structuur van de inalienabile groep is in het nieuw-pommers uiterst eenvoudig. $\mathrm{Er}$ zijn in het totaal 80 van dergelijke vormen. Niet minder dan 54 daarvan duiden menselijke lichaamsdelen aan. Geheel volledig is de indeling daarbij niet; met name een aantal woorden voor de inwendige delen zijn alienabel („Lunge”; „Milz”; „Eingeweide”). Uka-na „Schwanz” noemt een dierlijk lichaamsdeel; kuru-na „Penis, Schwanz" staat op de grens tussen de menselijke en dierlijke sfeer. Verder zijn er nog 19 verwantschapsnamen. En tenslotte is er nog een peripherie van 6 andere woorden. Drie daarvan hebben betrekking op het geestelijke wezen van de mens (tulungea-na „Geist, Seele, Schatten”; nuknuk „Gedanke, Absicht, Vorsatz, Ansicht” (vgl. nuk, nuknuk ,denken”) ; nilai-na ,Stimme”) ; twee noemen typisch persoonlijk bezit (kuba, kuba-na ,Heimat, Haus, Wohnung, Zimmer, Kahn”; palakau, palakau-na „Schuh”. (vgl. palakaur „Bambusstreifen”)); en tenslotte is daar de vorm pire ,bei, neben, zu, hinzu" ${ }^{23}$ ).

Welke kategorie zich hier met deze serie vormen aftekent in de taal, is wel niet twijfelachtig. Men staat hier voor wat de psychologie de

22) A. Constantini, Theoretisch-praktischer Lehrgang der neupommerschen Sprache (Bismarck-Archipel) nebst einem deutsch-neupommersch und neupommersch-deutschen Wörterbuch, Berlin 1907. De woorden voor "Träne”; „heiser” (drukfout milaina voor nilaina, 107); „Kamm”; „Handtuch”, die Constantini vermeldt, ontlenen hun „personale Endungen” blijkbaar enkel aan de daarin vervatte namen van lichaamsdelen. $Z e$ worden hier daarom verder niet meegeteld.

23) Zie hierachter $24 \mathrm{v}$. 
menseliike persoon noemt, het gehele stelsel van al datgene dat subjectieve waarde heeft, en onverbrekelijk met het ,ik”, de drager van alle ervaringen, is verbonden. Daarom wordt hier allereerst de uiterlijke lichamelijkheid genoemd. De lichaamsdelen bouwen natuurlijk mede 's mensen wezen op. Voor de meer inwendig gelegen delen heeft de primitieve eilandbewoner van Nieuw-Pommeren echter nog geen oog. Maar pas door zijn clan, zijn huwelijksklasse deelt het animal sociale, dat mens heet, hier in het leven van de stam, zo leert ons de ethnologie. Pas daardoor krijgen allerlei individuele daden hier hun zin; daardoor worden zij ook op allerlei punten bijna dwingend bepaald. En zo scharen de verwantschapsnamen zich hier onmiddellijk naast de woorden voor lichaamsdelen. Beide groepen vormen in de grond een en hetzelfde geheel: het beeld van de persoon in een maatschappij, waar men minstens evenveel van en met elkander is als van zichzelf.

Van ,possessie” kan men bij de inalienabile kategorie daarom eigenlijk ook niet spreken. Tekens als $*_{k u} ; *_{m u} ; *_{n a}$, in de betekenis die deze in de melanesische en de oostelijke indonesische talen hebben, kan men onmogelijk stellen naast onze possessiva „mijn”; ,jouw”; ,zijn” enz. Lévy Bruhl, de ontdekker van de distinctie tussen de alienabile en de inalienabile vormen, merkt dit reeds met even zoveel woorden $\mathrm{op}^{24}$ ). En ook Prof. C. C. Uhlenbeck heeft dit later op grond van zijn noord-amerikaanse ervaringen ten volle bevestigd ${ }^{25}$ ). „Possessie”, ,bezitten”, ,hebben” veronderstelt de verhouding van een zekere meerwaardige kern tot een lager geplaatste en afgeleide peripherie. Er schuilt hier een zekere hiërarchie en dynamiek in de beleving. De westerling b.v. bezit zijn huis, zijn vistuig, hij heeft zelfs zijn verwanten, zijn lichaamsdelen, zijn ziekten. Maar voor de oosterling is juist het ontbreken van elke differentiatie in dit opzicht karakteristiek. Alles is voor hem ,inalienabel" wat tot de meest intieme kring van zijn persoonlijke sfeer, het psychologische $z o$-zijn behoort. De ervaring, en dus ook de aanduiding van de eigen persoon is verder ongeleed. Zou men dergelijke nuancen althans enigszins in de vertaling willen laten uitkomen, dan zou men b.v. voor nieuw-pommers tura-gu kunnen zetten ,mijn bloed-

24) L. Lévy-Bruhl, L'expression de la possession dans les langues mélanésiennes. MSL 19 (1916), 96 vv.

$\left.{ }^{25}\right)$ C. C. Uhlenbeck, Het identificeerend karakter der possessieve flectie in talen van Noord-Amerika; VAWA vijfde reeks, tweede deel (1917), 370 v. M. Leenhardt, Langues et dialectes de 1'Austro-Mélanésie, op. cit., XXVI ss. 
eigen broer; mon propre frère"; a bilau-m „die neus van jou, jouw eigen neus; ce nez à toi”; niuru-gu ,die verwanten (van moederskant) waarbii ik hoor, die schoot waarvan ik stam, het bloed dat mij gemaakt heeft" enz.

\section{Marshall.}

In het marshall vertoont de geleding der inalienabile groep juist hetzelfde grondbeeld als in het nieuw-pommers ${ }^{26}$ ). Alleen is de bezetting nu veel rijker, en - zoals altijd in dergelijke gevallen - vooral de peripherieën zijn verder ontwikkeld. In totaal telt men 164 vormen.

Daaronder vallen vooreerst 52 namen van lichaamsdelen. Woorden als kanniek „Fleisch”; bodökdök „Blut, Regel, Menstruum”; r'ä̈ „ausströmendes Blut”; kinej „Wunde”; menoa „Atem” sluiten zeker daarbij aan. Naar de agrarische sfeer leidt over ra, rä̈ „Glied, Ast”. Geheel daarin gelegen is in ieder geval zut „Blume; buchenähnlicher Baum".

De groep der verwantschapsnamen omvat 21 vormen. Op het gehele sociale verband als zodanig wijzen woorden als nugu „Familie (ganze Verwandtschaft)”; buij „Stamm, Geschlecht”; r'ōö „Volk, Untertan”; ook wel kabijúgenö „,Stammplatz”; ene „Land”; kīen „Gesetz”; lugui „Wirklicher (Vorgesetzter)”. In een enigszins andere, maar toch verwante orde van betrekkingen leeft men met jera „Freud”; jitenburu „Liebling, Herzliebst....”; rijilek „Bote, Apostel”; jebiä̈ „Helfer, Partner, Ratgeber"; äkijerat ",mein Feind (den ich hasse)".

Vervolgens is hier nog een groep woorden voor het menselijke uiterlijk, onderdelen van het toilet, schaduw, voetspoor, stem, graf, enz. Aneldog ö „Äuszere, Erscheinung”; bikdogu „Gestalt, äuszere Erscheinung”; möra „Äuszeres, Färbung”; rogoja „Schnitt, Form, Taille”; balle „Bekleidung, Bedeckung”; marö „Halsschmuck”; r’iö „Ohrschmuck”; roja „Büschel, Kranz”; kabitö „Flüssigkeit zum Einreiben oder Ölen”; āman „Waschwasser (für Gesicht und Hände)”. kijēiö „Aufenthalt, Verbleiben”; $b \bar{o} j a$ „Bereich, Herrschaft”; annañ „Schatten”; ära „Unterlage”; kiniö ,,jedwede Unterlage beim Liegen”; jinök „Fuszstapfen, Spur”; äda „Name”; ainigï̈ „Stimme, Laut”; kagälle „Zeichen”; jemlok „Ende”; lub „Grab”.

Maar de mens leeft en beweegt ook; hij gaat op jacht en deelt op zijn beurt in de buit van anderen! Jokon „Stab, Spazierstock”; būo „Gegen-

26) A. Erdland, Wörterbuch und Grammatik der Marshall-Sprache, Berlin 1906. 
stand zum Werfen”; emmar „Fischkörbchen”; mara ,id”; kona „Beute, Geliebte(r)”; kabjera „Anteil”; kannibäa „Speise für Festessen”; konāö „Arbeit, Sache, Aufgabe”; lugeja „Hindernis, Band”.

Nog meer spreken in dit verband misschien de woorden voor de typisch-menselijke hogere vormen van individualiteit, zijn karakter, zijn steeds weer wisselende stemmingen, sociale verplichtingen enz. Dü̈ „Charakter, Geistesrichtung”; muilï „Charakter, Temperament, Wesen”; äbejen „seine Weise”; wärein „Betragen, Art und Weise, Handlungsweise”; kilä̈ „Wille, Bestimmung”; añö „Stimmung, Fassung”; buñburu „sich erfreuen” (wörtl. Kehle geht auf)” ${ }^{27}$ ); mijlôgu „Wonne, Lieblings....”; jüboga „erste Angst, peinigendes Angstgefühl”; bôligi „perplex, ratlos”; (buñ)köloa „Wut”; kitouwa „Lobgesang, Lobpreisung”; anemkuoja ,,frei, zwanglos”; jelta ,wieder frei sein”: tellogu „,geziemend, zukommen”; noda „Schuld”; r'uo „id”; kobüeiö „Dankgeschenk”; jebña „durch Erstgeborenen gebrachte Speise”; wonäa „Preis, Zahlgeld, Bezahlung”; mudö „Einbildung, Selbstüberhebung”; lolu „Erfindung” ${ }^{28}$ ).

Een geheel nieuw punt is, dat men in het marshall ook regelmatig de „personale Endungen” vindt bij een hele serie woorden met locaaldeictische betekenis als rechts, links, achter, voor, bij enz. Wat mag de oorzaak zijn van deze merkwaardige uitbreiding, waarvoor het nieuw-pommers in het geheel geen parallel bezit? ${ }^{20}$ ). Schuilt hier dan ook al een typisch personale noot in de beleving? Bühler heeft in zijn Sprachtheorie reeds duidelijk uiteengezet, dat dit laatste werkelijk het geval is ${ }^{30}$ ). Woorden als rechts, links, bij, rondom enz., zo zegt hij, betekenen telkens weer iets anders. Men verstaat ze niet nauwkeurig vòòr men weet wie ze heeft gesproken. Ieder persoon is in dit opzicht weer het centrum van een geheel eigen, onverwisselbaar deictisch systeem. Bij elke tournure in het gesprek wisselt weer de „personale Diakrise", die hier wordt gevraagd. In de westerse talen verdwijnen nu dergelijke subjectieve nuancen tengevolge van de abstractie, die

27) A. Erdland, op. cit. 185 : „die Kehle gilt als Sitz der Gefühle und Empfindungen. Jemanden betrüben heiszt kabiiil buru $=$ Kehle heisz oder brennend machen".

28) mijmij lôlu ,geduldig, nachsichtig, langmütig” en el'naīkadü „wiedervergelten" danken hun persoonstekens resp. aan lôlu „Magen, als Sitz des Verstandes und der Tatkraft (Erdland, op. cit. 189)" en kadü „Seite, Flanke”.

29) Zie echter nieuw-pommers pire ,bei, neben”. Hiervoor 21.

30) K. Bühler, Sprachtheorie 79-120; H. Frei, Systèmes de deictiques, Acta Linguistica 4 (1944), 111. 
hier algemeen heerst. De primitieve eilandbewoners der Marshallgroep blijven deze echter regelmatig uitdrukken, en zo zeggen zij daarom niet kortweg rechts, links, achter, maar rechts-bij-mij, links-bij-U, achterbij-hem enz.

Het sterkst blijkt dit onderscheid met de westerse opvatting misschien wel bij het stelsel der richtingaanwijzers: noorden, zuiden, oosten, westen. Ook dit systeem is voor ons weer algemeen geldig en objectief geworden. Elke individuele of specifieke notie is daarbij weggevallen. Maar de atolbewoner, die veel met winden en stromen te maken heeft ${ }^{31}$ ) spreekt ook hier weer regelmatig van irög- $u$,in Süden ( $\left.r a k\right)$ von mir”; irögu-m ,im Süden von dir”; irögi-n ,im Süden von ihm”; $i \ddot{a} \tilde{n}-\ddot{u}$, ,im Norden (eañ) von dir"; iriligi-n, ,in Westen (rilik) von ihm" enz. En nergens blijkt uit Erdland's gegevens, dat daarnaast reeds een ander dergelijk stelsel van meer objectieve aard in gebruik is ${ }^{\mathbf{2}}$ ).

Soms helpt de etymologie ons in deze gevallen te achterhalen, welke algemeen gekende aanschouwelijkheden als brug gediend hebben bij de vorming van het localiseringssysteem. Bij andere aanduidingen ontgaat ons echter ook dit détail. Zo luiden links en rechts b.v. in het marshall resp. $\bar{a} n$-buij-ban en $\bar{a} n$-buij-marō $\tilde{n}$. Hierin is $\bar{a} n$ niets anders dan het personale van de derde persoon ,er, sein”; buij is „Stamm, Geschlecht”; maar ban „nicht können, nicht vermögen” en marōñ (in) „können, fähig, Fähigkeit, Macht”. Zouden dergelijke vormen, zo. is men geneigd zich af te vragen, oorspronkelijk dus niet wijzen op de beide exogame stamhelften? Met de rechter stamhelft kan men wel huwen, maar met de linkerhelft niet. Welk analogon ligt ook meer voor de hand voor een dergelijk geval in een maatschappij als deze?

In andere gevallen, zoals b.v. bij sommige praeposities, heeft ook weer het menselijk lichaam als oorspronkelijk oriënteringsschema gediend. Eveneens dus weer een zeer tastbare en goed bekende werkelijkheid! Zo staat b.v. $i$-logan ,nach, hinter" eenvoudig naast lok, logan „Schwanz"; $i$ - is een locaal partikel ,in (Ort)”. Alik „obere Seite (Dach, Stoff, Hand)" is tegelijkertijd het woord voor "Rücken”; vgl. nedl. de rug van de hand, fra. le dos d'un montagne; ital. dosso d'un arco enz. In nog andere gevallen hangen de praeposities samen met de personalia. De gewone verhoudingen in het gesprek hebben hier als

31) A. Erdland, op. cit. 190.

32) Vg1. ook Erdland's opmerking „Die Westseite eines Atolls gilt als Basis, die Ostseite als Haupt (baran ailiñ) (188, s.v. kabin ailiñ). 
voorbeeld voor het localiseringsschema gediend. Zo is $i$-kij-en "gegenüber, vis à vis" niet los te maken van $k i j$,uns (einschl.)". De vorm betekent ongeveer ,in dezelfde kring als, vlakbij, samen" ${ }^{33}$ ).

Men ziet dus hoe, alles bijeengenomen, het reliëf en de taalkundige aanduiding van het persoonlijkheidsbeeld in het marshall aanmerkelijk is verdiept. Zoals gezegd, blijven de grondtrekken echter vrijwel gelijk aan die in het nieuw-pommers. Naast de zuiver uiterlijke lichamelijkheid komt nu b.v. tot op zekere hoogte ook het geestelijke wezen van de mens naar voren. Zelfs allerlei min of meer abstracte qualificaties worden gemeten aan de ervaringen van het eigen, onmiddellijke, psychologische zijn. Het griekse ăv $v \varrho \omega \pi о \varsigma ~ \mu \varepsilon ́ \tau \varrho o v ~ \pi a ́ v \tau \omega \nu$, dat oorspronkelijk philosophisch bedoeld was, wordt hier op deze wijze tot bijna tastbare taalkundige werkelijkheid.

\section{De tanimbartalen.}

De tanimbartalen staan elkaar zo na, dat we deze wel tegelijk kunnen bespreken. Men kan het volgend overzicht geven ${ }^{34}$ ).

\begin{tabular}{|c|c|c|c|c|c|}
\hline & & jamdena & slaroe & fordata & paulohi \\
\hline \multirow{5}{*}{ 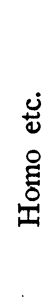 } & Menselijke lichaamsdelen & 81 & 60 & 64 & 24 \\
\hline & dierlijke delen & 6 & 6 & 5 & 8 \\
\hline & delen van planten & 14 & 16 & 9 & 16 \\
\hline & de verschijning van de mens & 18 & 5 & 12 & 6 \\
\hline & Verwanten & 9 & 12 & 18 & 8 \\
\hline \multirow{3}{*}{ } & Delen van inanimata & 23 & 16 & 22 & 12 \\
\hline & eigenschappen enz. & 15 & 8 & 15 & 2 \\
\hline & Loca 1 ia & 18 & 6 & 16 & 7 \\
\hline
\end{tabular}

33) Volledigheidshalve volgen hier nog, zonder verder commentaar, de overige nomina localia met persoonswijzers; ibben ,bei, mit (bei Personen)"; iomin „unter”; ion ,auf, über”; jigin „Platz, Ort”; ituru „rundum, neben” (met enkele daarvan afgeleide vormen); joñak „Masz”; boga wot ,passendes Masz”.

34) P. Drabbe. Spraakkunst der Fordaatsche taal. VBG 67 (1926), eerste stuk; -, Woordenboek der Fordaatsche taal, VBG 71 (1932), tweede stuk; -. Spraakkunst der Jamdeensche taal, VBG 67 (1926), tweede stuk; -, Woordenboek der Jamdeensche taal, VBG 71 (1932), eerste stuk. -, Beknopte spraakkunst en korte woordenlijst der Slaroeëesche taal, VBG 71 (1932), vierde stuk. 
De oude kernen, nl. de namen der menselijke lichaamsdelen en der verwantschapsnamen, herkent men hier onmiddellijk. Alleen is het aantal van deze laatste, relatief genomen, nu opvallend gering. De betekenis van het sociale element bij de persoon moet dus wel naar evenredigheid zijn teruggelopen. Daarnaast hebben de peripherieën zich echter blijkbaar ook bijzonder ruim ontwikkeld. Karakteristiek voor de stand der ontwikkeling is daarbij, dat die der agrarica onmiddellijk drukker bezet zijn dan die van de dierlijke delen. Men heeft b.v. in het fordata : ana „tak, zijtak van een weg”; sana „tak, zijweg”; ala ,mik van een tak"; roa „,blad”; jata ,half geopend blad"; roeboe ,scheut van planten”; imoe ,scheut uit takken of stam”; foeoe „bloem, bloesem"; koeka ,bolster van rijst”.

De tekening der menselijke levensaspecten, die in het marshall zo levendig en volledig was, blijft in de tanimbartalen weer tot de uiterlijke feiten beperkt, ongeveer dus als in het nieuw-pommers. Bijv. fordata: eri „tegenwoordigheid”; wea ,gedaante, voorkomen, uiterlijk”; vera „gedaante”; fella ,vorm, voorkomen”; mola „schaduw, spiegelbeeld”; nara ,naam”; waloe ,,afbeelding, beeltenis”; ngrä̈ ,ziel”; oetoe ,voorspoed, geluk, voordeel”; froa ,zorg voor iets”; veli ,koopprijs van een vrouw”; fjazea „koopprijs, waarde, prijs”.

Verreweg het voornaamste nieuws dat de tanimbarklassificatie te zien geeft, is echter de groep der inanimata. De inalienabile kategorie was in de tot nu toe besproken talen streng gecentreerd rond de menselijke persoon. Welnu, deze gedachtenoriëntatie wordt hier nu voorgoed verlaten. Men slaat in dit opzicht duidelijk totaal nieuwe wegen in. In het jamdena b.v. kan men de groep der inanimata nauwelijks nog de mindere noemen van die der hominiene feiten, ook om het aantal. $N d a n d i r$,verdieping, laag”; bange ,trede van trap, sport van ladder”; sefi ,baan van goed”; roenge ,de zak van een stenen fuik”; wele ,dat deel van een mes dat in het heft zit"; folas ,een kort stuk van hout"; bindar ,schilfer, spaander”; snjai ,straal”; foloer ,,vlam”; ocme ,vlaag (b.v. van de wind)"; soesoe ,hoek”; soei ,rand, zijde”; klilikoe ,holle kant”; bare „gloeiende kool”; etoe „vuurkooltje, vonk”; jare ,houtskool"; aoe ngloean ,houtskool, as, houtas"; lije „overblijfsel”; moende „restje van vloeibare waar”; roefoe „kruimel”; tebal „,overblijfsel”; roboe, ide ,scherf”; sningat „stop”.

Zelfs krijgt men de indruk, dat de nieuwe halve kern der inanimata ook op haar beurt reeds weer een peripherie rond zich heeft ver- 
zameld. Er komt hier althans ook een serie namen van kwaliteiten, algemene eigenschappen enz. voor, die opmerkelijk volledig is, maar zeker geen speciaal hominien karakter draagt. Labar „breedte”; lawas „lengte”; dasi „,hoogte”; sljai „grootte”; fele „,vorm, uiterlijk, gedaante”; bai „kracht, waardigheid”; berat ,gewicht, zwaarte”; ngat ,geur”; nanam ,smaak”; mone ,het goede van iets”; jange ,geneeskracht, goed voor”; odir „licht”; idak „schittering, glans, licht”; fanas „hitte, warmte”; kotak ,waarde”.

Tenslotte geldt nog een aantal nomina localia in de tanimbartalen als inalienabel, juist als in het marshall. Maar ook hier is de invloed van de hominiene kern blijkbaar aan het afnemen. Zo zijn in het archaische slaroe b.v. alle praeposities nog vrij regelmatig afgeleid van namen van lichaamsdelen, maar in het fordata is dit laatste in een lijst van zestien van dergelijke voorbeelden nog slechts met één het geval. Slaroe $k$-eta „buiten” naast eta „rug”; vgl. ook een geval als $k$-hihi-ke ,de scherpe kant van iets” maar hihi ,lip, mond” enz.

Men gaat wel niet te ver, met de wijzigingen van het persoonlijkheidsbeeld in de tanimbartalen als een min of meer principiële heroriëntatie te beschouwen. Het individu heeft zich hier blijkbaar tot op zekere hoogte losgemaakt uit het sociale kader, waarin dit tot nu toe geheel paste. En blijkbaar in verband daarmee vervangt nu ook het beeld van de wereld als geheel dat van de menselijke persoon alléén. Naast de totnutoe enkel geldende personalia krijgen aldus ook de inanimata hun kans.

\section{Paulohi.}

Blijft er in de tanimbartalen misschien nog enige onzekerheid bestaan over de één- of tweepoligheid van het inalienabile verband, in het paulohi van Seran is deze vraag in ieder geval geheel opgelost ${ }^{35}$ ). De groep der inanimata staan hier duidelijk als gelijkwaardig naast die der namen van menselijke lichaamsdelen enz. De oude indeling is langzaam maar zeker uitgemond in een openlijk systeem van nominale klassificatie, dat alle kenmerken vertoont die de grammatica daarvoor gewoonlijk kent. Dat er vanouds reeds een zekere klassificatorische inslag school in de tegenstelling tussen de alienabile en de inalienabile groepen,

35) E. Stresemann, Die Paulohisprache, 's Hage 1918. 
valt niet te miskennen. In het paulohi heeft deze echter de overhand genomen, en het resultaat is dus wel heel afwijkend van de oorspronkelijke toestand in het melanesisch. In de derde persoon van het personale, de gewone plaats dus waar zich volgens W. Schmidt een opkomende nominale klassificatie begint te uiten ${ }^{36}$ ), onderscheidt ook het paulohi twee vormen bij de zelfstandige tekens; resp. ile „er” maar jele „es” (als substantief „das Ding”), en in het meervoud sile „sie” (personaal) maar jeru ,sie” (neutraal, naar de terminologie van Stresemann). Zo ook bij de prefixen in het singulare resp. $i$ - en $e$-, in het meervoud $s i$ - en $u-$; en bij de suffixen sg. $-i(-n i)$ tegenover $-e(-i e)$ en pl. $-s i$ tegenover -ru (-eru). $\mathrm{Nu}$ doen de derde persoonstekens in de AmbonTimorgroep, juist als in zoveel andere indonesische talen ${ }^{37}$ ), tevens ook dienst als pluraalelementen. Vandaar dat de nominale klassificatie zich hier, althans op één punt, zelfs ook reflecteert bij de meervoudsvorming der nomina. De neutrale vormen hebben -ru (de „Hilfsplural” van Stresemann), de personale daarentegen $-a$ of -ia. B.v. lima-si-ru ,ihre Hände" ${ }^{38}$ ) maar ina-ia ,die Mütter”.

Een ander typisch indicium, dat op de verzwakking van het oorspronkelijke nominale indelingsprincipe in het paulohi wijst, is nog, dat de verwantschapsnamen hier, althans in het meervoud, hun persoonstekens niet suffigeren maar prefigeren. Blijkbaar zijn ze in dit opzicht dus reeds meegetrokken door de alienabilia, die steeds prefigeren. Men vergete daarbij niet, dat de nieuw geconstitueerde groep der inanimata practisch vrijwel geheel onder de alienabilia valt. De aanval op de kern der inalienabile groep zal daaraan wel zijn grootste kracht hebben ontleend. Men heeft b.v. van het alienabile $u t u$,Laus” regelmatig $u$-utu; $m u$-utu enz.; eveneens in het meervoud $u$-utu-a; mu-utu-a enz. Maar van een verwantschapsnaam als ina "Mutter” in het enkelvoud resp. ina-u; ina-mu; ina-ka (1 incl.) ; ina-ma (1 excl.); daarentegen in het meervoud ka-ina-ia (1 incl.); ma-ina-ia (1 excl.) enz.

36) W. Schmidt, Die Sprachfamilien und Sprachenkreise der Erde, Heidelberg 1926, 346; G. Royen, Die nominalen Klassifikations-Systeme in den Sprachen der Erde, Mödling bei Wien 1923, 368 vv; J. van Ginneken, Grondbeginselen van de schrijfwijze der nederlandsche taal, Hilversum 1931, 134-159.

37) H. Geeroms, Over de derde persoon meervoud in het austronesisch. BTLV 102 (1943), 41-79.

38) Voor deze indeling bij de neutrale vormen zie E. Stresemann, Die Paulohisprache $42,34 \mathrm{v}$. 
Men ziet, hoe gecompliceerd de affigeringstechniek van het paulohi door al de beschreven hele en halve uitzonderingen geworden is. Hier ligt zeker één van de grootste moeilijkheden van deze taal. Stresemann heeft echter de geldende regels, naar het mij voorkomt, slechts weinig verhelderd met al zijn nieuwe termen. De hier gegeven schets van de ontwikkeling maakt een redelijke indruk, en sluit niet minder aan bij wat van de omringende talen bekend is.

Wat de richtingsnamen betreft, is het corporele oriënteringsschema dat in het marshall nog van zoveel betekenis was, in het paulohi geheel verlaten. Het verval van de hominiene klassificatiegroepen zal op deze ontwikkeling, die we ook reeds uit de tanimbartalen kennen, zeker zijn invlued niet hebben gemist. Als brugsysteem voor de verschillende deixistypen gelden thans de locaal-geographische eigenaardigheden van het eiland Seran. In de grond is het stelsel dus nog even subjectief als vroeger, maar de ervaringen van geheel het volk hebben nu deel daaraan. En er schuilt dus nu, naar verhouding, toch reeds heel wat meer objectiviteit en algemeen-geldigheid in. Zo luidt ,,in het oosten" in het paulohi eenvoudig lete ,hoog, in de hoogte”, omdat daar de hoogste toppen van het eiland liggen, wanneer men van het oorsprongsland van het paulohi uitgaat. Maar het westen heet wehe ,onder, daar beneden”. „Mijn huis bevindt zich in Paulohi” wordt weergegeven met au u-ruma we-i Paulohi (,hierin”); ,in Amahei” (en alle oostelijke stranddorpen) zou in dezelfde zin echter lete Amuhei "daarboven-inAmuhei" luiden; ,,in Ambon" (en alle in westelijke richting zichtbare plaatsen) wehe Kota "daarginds-in-de-laagte-in-Ambon” etc. ${ }^{39}$ ).

In het paulohi ligt, alles bijeengenomen, het zwaartepunt der inalienabile groep dus zeker reeds bij het extra-personale. De oorspronkelijke trekken van deze merkwaardige kategorie zijn totaal verdwenen. Dat juist de verwantschapsnamen daarbij het eerst en het meest door de nieuwe kern zijn aangetrokken, is wel geen toeval. Blijkbaar stelt ook hier de nieuwe ontwikkeling het individu meer op zich zelf. En zo

39) Stresemann vat het element $-i$ in deze gevallen min of meer als praepositie op (we-i „hier-in”). Men heeft hier m.i. echter met een verstard possessief teken van de derde persoon te doen. Men kan de ontwikkeling der locale betekenis volgen in gevallen als lale-i ,der Innenraum von etwas, das Innere von etwas"; lei-ni „die Auszenseite v. E."; men heeft b.v. sue ruma lale-i ,im Innere des Hauses" = im Hause; pakule sue mesa lehu-i „der-Korb dort Tisch Unterseite-sein" $=$ der Korb steht unter dem Tisch. 
houdt alleen de uiterlijke lichamelijkheid stand, waar het sociale wezen van de persoon reeds aanmerkelijk schade heeft geleden.

Vatten we thans kort samen: Wat heeft het gegeven overzicht van het melanesisch-indonesisch grensgebied ons nu geleerd? Het eerste punt is zeker een bevestiging van de traditionele mening over de ouderdom der nominale tweedeling. De distinctie tussen de alienabile en de inalienabile vorm van ,possessie" moet wel zeer diep wortelen in de austronesische taalgeschiedenis. We hebben de overgang naar meer modernere vormen stap voor stap kunnen volgen. Een tweede punt gaat echter tegen de gewone opvatting in. Men kan de inalienabile kategorie o.i. redelijkerwijze nòch voor het vluchtige reductieproduct, nòch voor het vrij toevallige randverschijnsel houden, dat Prof. Jonker, resp. Kanski en Kaprusch, daarvan hebben willen maken. Men staat hier voor een verschijnsel sui generis, één van de voornaamste trekken die de oostelijke indonesische talen maken tot wat ze zijn. Het directe getuigenis van de taal interpreterend, kan men zeggen, dat het individuele stamlid bij de oostelijke indonesische stammen, en a fortiori bij de westelijke verwanten, een veel vrijer standpunt moet hebben ingenomen t.o.v. het clanverband waarin hij oorspronkelijk leefde, dan dit voor zijn voorvader, de oer-austronesiër, mogelijk was. Er moet op dit punt op de duur een aanmerkelijke verschuiving van het accent zijn ingetreden. Het persoonlijke, strikt individuele element kwam hoe langer hoe meer naar voren. En het is dus wel zeer waarschijnlijk, dat geheel de taalkundige ontwikkeling die we hier hebben bestudeerd, in de grond niets anders voorstelt dan het linguistisch correlaat van een belangrijke ontwikkeling, waarvan de diepste oorzaak echter allereerst op sociologisch terrein zal zijn gelegen. In een geval als dit is het de taal clie registreert, maar de sociologie die ordineert en determineert ${ }^{40}$ ).

40) De nominale klassificatie van het paulohi verdient nog een ogenblik de aandacht. Het stelsel dat hier voorkomt, heeft zich vrijwel zonder uiterlijke stoornis uit het melanesische systeem der beide "possessie"-vormen ontwikkeld, naar wij hebben gezien. Uit de tegenstelling: „van-de-eigen-persoon”: „niet-van- 


\section{HOOFDSTUK $v$}

\section{De ontwikkeling van de genitief in de oostelijke talen.}

In het voorgaande hebben we enkele van de meest oostelijke indonesische talen met de melanesische talen vergeleken, en als onwillekeurig is de aandacht daarbij vooral gevallen op het verval van het taalsysteem. In de vormleer gaat het echter juist als in de klankleer, waar accentverzwakking gewoonlijk het gevolg is van verplaatsing van het hoofdaccent naar een andere silbe. Zo zijn ook in de morphologie deflectie en nieuwbouw meestal als twee kanten van een en dezelfde zaak, ze staan tot elkander als gevolg en oorzaak. Het mutatieverlies brengt winst, en uit het z.g. vervalproces komt de taal in werkelijkheid zuiverder te voorschijn ${ }^{41}$ ). En de vraag is dus nu maar, welke nieuwe hoofdtendenz hier de vroegere distinctie tussen de alienabile en de inalienabile vorm van ,possessie” ten val heeft gebracht? Waardoor heeft dit toch zo diep gefundeerd en begrijpelijk systeem naderhand zijn kracht ingeboet?

Het antwoord kan zeer kort worden gegeven. We hebben hierboven

de-eigen-persoon" is die van ,persoon”: „zaak (inanimatum)” ontstaan. De overgang is begrijpelijk, maar blijft toch opmerkelijk, omdat het eerste stelsel volkomen subjectief maar het tweede objectief en algemeen-geldig is. Daarbjj komt nog, dat zich in allerlei talen rond het melanesische terrein, waar de distinctie tussen de alienabilia en de inalienabilia in verval is geraakt, juist hetzelfde heeft voorgedaan. Men vindt de tegenstelling „persoon”: „zaak” b.v. ook in melanesische randtalen als maewo, yabim, en verder in enkele talen van de Banks- en de Torreseilanden; in het indonesisch, behalve in het paulohi, ook in het slaroe, nufoor. De papua-klassificaties zijn in het algemeen meer ingewikkeld. Toch heeft Van der Veen reeds goed gezien, dat de tegenstelling „persoon”: „zaak” hier vaak ongeschonden teruggevonden wordt onder de bovenbouw van allerlei andere, later ingedrongen onderverdelingen (-, De noord-Halmahera'se taalgroep tegenover de austronesische talen, 12 vv.). Op Nieuw-Guinea keert ditzelfde b.v. terug in talen als valman, baining, monumbo, sulka. Ook op miriam, kota, bongu, marindinees zou hier tot op zekere hoogte gewezen kunnen worden. Er moet dus ook in de tegenstelling tussen de beide vormen van „possessie" wel reeds iets van een nominale klassificatie schuilen; anders zou de overgang tot de "gewone" grammaticale vorm daarvan wel meer moeilijkheden hebben opgeleverd. Op dit punt is de aandacht nog niet gevallen in de algemene literatuur $\left.{ }^{1}\right)$. Of is de klassificatorische inslag hier speciaal melanesisch-indonesisch? Het verschijnsel verdient nader onderzoek ook op andere gebieden.

41) O. Jespersen, Efficiency in linguistic change, Kopenhagen 1941.

1) Ook in mijn dissertatie is aan deze kwestie zeker niet voldoende gedacht. J. Wils, De nominalo klassificatie in de afrikaansche negertalen, 28 v., 159-162. 
een periode uit de indonesische taalhistorie gezien, waarin persoonselementen als $*_{k u} ; *_{m u ;} *_{n a}$ enz. nog niets anders aanduiden dan de eigen, individuele sfeer. Een vertaling van een vorm als jamdena wari-m met een nederlandse genitief ,,jouw broer" suggereert b.v. zeker een graad van onderschikking, die in het indonesisch in werkelijkheid in het geheel niet aanwezig is. Van casusvorming is in een dergelijke archipeltaal nog niet of nauwelijks sprake. Welnu, later zijn de bordjes in dit opzicht blijkbaar verhangen. Er ontstaan wèl casus; en met name vormt zich een genitief, waarin nomen regens en nomen rectum werkelijk deze naam verdienen. Het ,bezitten”, „,hebben” vindt nu wel een adaequate uitdrukking in de taal. Een vorm als maleis $k u d a-k u$ wordt b.v. ook grammaticaal vrij goed met „mijn paard” weergegeven. $\mathrm{Nu}$ berusten kategorieën als deze laatste, zoals reeds vermeld, juist op een scherpere stratificatie in de ervaring. De kern van de gehele persoonlijkheid, het ik, wordt duidelijk gevoeld als meer centraal geplaatst; het ,bezit" geldt ten opzichte daarvan als secundair en afgeleid (22 v.). Men ziet dus dat ook de sociologisch-psychologische lijn van ontwikkeling die we hierboven gevonden hebben, op deze wijze volkomen tot haar recht komt. De aansluiting laat in dit opzicht niets te wensen over $^{\mathbf{4 2}}$ ).

Daarbij komt nog, dat deze laatste ontwikkeling, zoals het gegeven voorbeeld al aanduidt, volstrekt niet enkel beperkt is tot de talen met nominale tweedeling (d.w.z. de tanimbartalen, kei, boeli, nufoor, een aantal seran-dialecten, kisser, timor, koepang). Men vindt de sporen daarvan ook elders. Ja zelfs, hoewel in mindere mate en in enigszins gewijzigde vorm, ook in wat Brandes de ,westelijke" afdeling der indonesische talen heeft genoemd. Daarentegen vertonen de melane-

42) De psychologische en taalkundige literatuur over het begrip „bezit” en de genitief is zeer uitgebreid. Men zie b.v. H. Ebbinghaus-E. Dürr, Grundzüge der Psychologie ${ }^{3}$, dl. II, 229; Th. Lipps, Das Selbstbewusztsein, Leipzig 1895; cap. 10 en 11; W. James, Psychology I, ch. X; Ch. Blondel, La personnalité, in G. Dumas, Traité de Psychologie II, 522 vv.; R. Müller-Freienfels, Philosophie der Individualität'2, Leipzig 1923; E. Galli, Nel dominio dell' „Io”, Milano 1919; P. Janet, L'évolution psychologique de la personnalité, Paris 1929; W. Stern, Person und Sache III, Wertphilosophie, Leipzig 1924; L. Brunschvicg, De la connaissance de soi, Paris 1931; M. Scheerer, Die Lehre von der Gestalt, Berlin 1931 ; G. Marcel, Phénomenologie de l'avoir, Recherches philosophiques III (1933-34), 67; G. Stern, Ueber das Haben, Bonn 1928, 138 vv.; A. A. Grünbaum, Het Ik-bewustzijn en de psychische ontwikkeling, Inaugur. Rede, Utrecht 1928; J. Wils, De persoon in de taal, Onze Taaltuin 6 (1937); 177-197 (met verdere literatuur).

Verh. dl. XII. 
sische en de polynesische talen weer niets van die aard. We staan hier dus, alles bijeengenomen, zeker voor een verschijnsel dat ten volle onze aandacht verdient. En als we van de oostelijke indonesische talen gezegd hebben, dat deze mede door het onderscheid tussen de beide vormen van ,possessie” worden tot wat ze zijn, dan geldt juist hetzelfde zeker in niet mindere mate voor de meer westelijk gelegen talen ten aanzien van dit merkwaardig bezit van een zekere primitieve vorm van "genitief”. Mede door deze trek wordt, zo kan men zeggen, het oeroude austronesische erfgoed hier blijkbaar pas tot de eigen, volle ,indonesische" taalstijl omgevormd.

Hoe de ontwikkeling in dit verband verlopen kon, was door de gegeven omstandigheden als vanzelf aangewezen. Er heerst in dergelijke gevallen een zekere ,wet tot behoud van de linguistische energie”, of een „wet van de minste weerstand” in de taal, zo leert de ervaring. De nieuwbouw voltrekt zich steeds, voorzover dat kan, op de basis van de oude resten. Elke reïnterpretatie is tegelijk ook (de term zelf zegt dit reeds) een halve triomf van het conservatisme. En zo sluit ook hier nu het nieuwe casusstelsel weer zoveel mogelijk bij de bestaande nominale tweedeling aan. De nieuwe genitief vindt daarbij begrijpelijkerwijze vooral steun bij de alienabile kategorie. Ook hier immers bestond van te voren reeds een zekere distantie tussen de kern en de peripherie van de persoon, terwijl de inalienabile vorm juist de ongescheiden eenheid van deze beide weergeeft. Vandaar dat men zich in de indonesische talen de meeste latere genitivische casustekens ook ziet ontwikkelen, zowel op de plaats als uit de vormen van de vroegere alienabile possessie, d.w.z. vóór het nomen, en òfwel uit de oude ,possessives” òf uit de oude persoonstekens zonder meer. Van de oorspronkelijke denk- en uitdrukkingsgewoonten blijft op deze wijze zoveel mogelijk gespaard. Alleen de meer westelijke gelegen talen maken, althans ten dele, een zekere uitzondering op deze regel. De oude persoonstekens zijn hier enkel als suffix achter het nomen bewaard, dat wil dus zeggen op de oude inalienabile plaats. We komen hierop nog nader terug.

Men kan bij de ontwikkeling van de genitief, globaal genomen, drie partiële ontwikkelingstendenzen onderscheiden. Dat deze elkander herhaaldelijk kruisen, remmen of juist verder voortstuwen, behoeft niet apart vermeld.

A. Vooreerst gaat op de duur de alienabile vorm van „possessie” in een groot aantal indonesische talen blijkbaar als het normale geval 
gelden. De alienabilia nemen de leiding in het nominaal systeem. Zo zich ergens nieuwe bouwprincipen of uitbreidingen van het gebruik voordoen, dan is dit steeds weer hier. De inalienabile vorm, vroeger de vaste positieve pendant van het systeem, wordt voortaan naar een uithoek der grammatica verbannen.

B. Een tweede gezichtspunt is, dat de nieuw ontwikkelde casustekens vrijwel alle streven naar de plaats vóór het nomen. De oude inalienabile tekens daarentegen stonden achter, naar we weten. Dit punt hangt natuurlijk nauw met het voorgaande samen.

C. Bijzonder interessant is het tenslotte na te gaan, hoe bij de inalienabilia langzamerhand een algemene, onpersoonlijke vorm is ontstaan. In de oude stijl kent men bij deze kategorie natuurlijk slechts de vormen met persoonstekens. Een abstracte of onpersoonlijke vorm komt daarnaast niet voor. Fordata jama- $\dot{n}$,,mijn vader”; jama-m ,uw vader”; jama-n ,zijn vader”; jama-d, jama-dida ,onze vader (incl.)”; jama-m, jama-mami ,onze vader (excl.)"; jama-b, jama-bir ,uw vader (meerv.)"; jama-r, jama-rir „hun vader”. Maar een algemene vorm voor ,vader”, „de vader, een vader” zoekt men daarnaast tevergeefs. Gewoonlijk is het nu de derde persoon, die van nature reeds als de meest algemene en onpersoonlijke kan gelden, die in de latere, meer objectieve tijd wordt veralgemeend. Maar er zijn ook verschillende andere mogelijkheden.

Bijna alle talen, vooral die uit het Oosten, bezitten één of meer trekken die met de beschreven ontwikkelingslijnen in verband staan. We geven van de overvloed der feiten echter slechts zoveel, als voor de gang van het betoog nodig is.

\section{A. De ontwikkeling van de pronominale genitieftekens.}

Onder de indonesische talen is er minstens één, die wat de affigering der possessieve tekens betreft, nog volkomen op het oeroude melanesisch-austronesische standpunt is blijven $\operatorname{staan}^{43}$ ). Deze taal is de meest zuidelijke der Tanimbartalen, het slaroe. Van de vorming van een genitief valt hier nog in het geheel niets te merken. Wasi „eigendom" treedt als "possessive” op. En zo vindt men hier b.v. anak-kwe $(a n a-k u-k e)$; anam-kwe (<ana-mu-ke) ,mijn (jouw) kind” enz.;

43) Of staat men hier misschien voor een secundaire ontwikkeling? Een „terugvallen" dus op het vroegere melanesisch-austronesische standpunt? 
maar wasi-k sekje (< wasi-ku sei-ke) „eigendom-mijn-huis”; wasi-m as-kwe ,jouw hond" enz. Overal elders zijn de klare lijnen van het oorspronkelijke systeem echter op de een of andere wijze aangetast of verwrongen. Het project van de nieuwe naamval eiste ook een nieuwe structuur in de vormen. Men kan de overvloed der feiten althans enigszins ordenen, door achtereenvolgens na te gaan: 1e. de verstarring der oude suffixen; 2e. de ontwikkeling der ,possessives”; en tenslotte $3 \mathrm{e}$. het indringen der personalia in het possessieve systeem. Dat ook in dit geval de drie te bespreken lijnen niet volledig gescheiden kunnen worden, spreekt van zelf.

\section{a. De verstarring der oude suffixen.}

Een prachtig voorbeeld van de langzame verstarring der oude possessieve suffixen leveren de serandialecten, die vooral door de studies van Stresemann en Tauern bekend zijn geworden ${ }^{44}$ ). De oer-austronesische stijl is hier in zoverre in het possessieve tekensysteem nog ten volle bewaard gebleven, dat alleen de "possessives” zijn verdwenen, en wel zonder enig spoor achter te laten. De inalienabilia suffigeren in deze talen m.a.w. als vanouds hun persoonstekens, maar de alienabilia prefigeren deze. Een eenvoudige distinctie in het uitdrukkingstelsel, die aan duidelijkheid niets te wensen overlaat! Als nu echter het nieuwe begrip ,bezit” begint in te dringen, kiest dit zijn weg speciaal over de alienabile kategorie, zo hebben we reeds gezien (34 v.). De prefixplaats krijgt daardoor een zeker overwicht; de suffixen worden min of meer op een zijlijn gerangeerd. En wat niet kon uitblijven, geschiedt dan ook. De functieverzwakking leidt langzaam maar zeker tot vormverzwakking. Men kent het belangrijke principe dat Horn reeds in zijn boek voor dergelijke gevallen heeft gesteld ${ }^{45}$ ).

Zo zijn de prefixen en de suffixen hier in de dialecten van Wemale, Makabala, Paulohi, Lissabata nog geheel aan elkander gelijk. In die van Seleman en Uhei-Kachlakim hebben echter juist de suffixen al aanmerkelijk geleden. In het singulare heeft men b.v. Seleman 1. humaar $-u$; 2. mu- maar $-m$; 3. ni- maar $-i$, $-n i$; neutrum $n i-$ maar $-n$. En in het meervoud is de suffixrij zelfs reeds geheel opgelost, terwijl de

44) E. Stresemann, Die Paulohisprache, 's Hage 1918; -, Die Lauterscheinungen in den ambonischen Sprachen; BZES 10 (1927); O. D. Tauern, Beitrag zur Kenntnis der Sprachen und Dialecte von Seran, Anthropos, D1. 23 (1928), 1000-20; 24 (1929), 953-81; 25 (1930), 567-78; 26 (1931), 109-39.

45) W. Horn, Sprachkörper und Sprachfunktion², Berlin 1923. 
prefixrij nog geheel intact is. In het Liambatadialect (bonfia) wordt het onafwendbare eindpunt van de ontwikkeling bereikt. Van suffixen valt hier geen spoor meer te bekennen, maar de prefixen fungeren nog als vanouds. Was onderwijl het gevoel voor de oorspronkelijke nominale tweedeling niet aanmerkelijk verzwakt of zelfs geheel verdwenen, dan zou een ontwikkeling als deze laatste zeker niet mogelijk zijn geweest.

De ambon-dialecten staan practisch op hetzelfde standpunt als de serandialecten van Seleman en Uhei-Kachlakim. Alleen is toevoeging van het personale aan de possessieve constructie hier nog meer gebruikelijk dan reeds op Seran. Het is daarom niet onwaarschijnlijk dat zich nu, historisch gezien, ook juist dezelfde ontwikkeling heeft afgespeeld. Baron van Hoëvell ontkent dat er thans nog iets van een nominale tweedeling op Ambon bestaat, Jonker heeft echter daarvan in de teksten nog resten teruggevonden ${ }^{46}$ ). Men heeft b.v. Asiloeloe in het singulare au lima-ku, ,mijn hand" maar in het meervoud ami ma-lima "onze hand" (excl.); imi mi-lima „uw hand"; sini ri-lima „hun hand" enz.

\section{b. De ontwikkeling der ,possessives".}

De ontwikkeling der ,possessives” is natuurlijk niet zo fataal verlopen als die van de zoëven besproken suffixen. Deze tekens liggen daarvoor te ,gunstig”, aan het begin van het woord, juist waar in de nieuwe ontwikkeling de hoofdaandacht gaat vallen. En vooral, de „possessives" zijn in hun onveranderlijkheid zeker ook veel minder kwetsbaar dan de oude suffixen. Eén van de meest gewone feiten in de oostelijke indonesische talen is daarom, dat de ,possessives" als vaste kernen gaan optreden voor de nieuwe genitieftekens. De verschillende persoonselementen groeperen zich dan daaromheen. Dat er daarbij van hun oorspronkelijke functie niets overblijft, spreekt vanzelf. Ook de vorm kan tot onherkenbaar wordens toe worden verminkt.

Een voorbeeld van een dergelijk ingewikkeld kristallisatieproces vindt men bij de possessieve tekens van de Tanimbartalen en het kei, waarvan hier een overzicht volgt (pag. 38).

Men ziet welk een ingewikkeld stelsel hier is ontstaan. De vormen voor de nieuwe naamvalsfunctie zijn blijkbaar van alle kanten bijeen-

46) G. Baron van Hoëvell, Iets over de vijf voornaamste dialecten der Ambonsche landstaal (Bahasa Tanah), BTLV 4e vlgr. I (1877), 1vv. J. Jonker, Rottineesche Spraakkunst 353. 
gegaard. Als een vaste baken in de woelige zee verrijst echter in het singulare het ,possessive" ni. Men kent dit reeds uit de verwante, naburige talen, en ook uit het melanesisch. In het meervoud is $n i$ echter weer verdwenen ${ }^{47}$ ).

\begin{tabular}{|c|c|c|c|c|c|c|}
\hline & \multicolumn{2}{|r|}{ kei } & \multicolumn{2}{|c|}{ jamdena } & \multicolumn{2}{|c|}{ fordata } \\
\hline & enkelv. & versterkt & enkelv. & versterkt & enkelv. & versterkt \\
\hline Sg. 1 & $\operatorname{nin}$ & (yau) nin & ninu & (yak) nin & Sninu, ninu, & S(yạa) ninu, \\
\hline 2 & $\mathrm{mu}$ & (o) $\mathrm{mu}$ & nime & (ko) nim & $\begin{array}{l}\text { (nin, nin } \\
\text { mu }\end{array}$ & $\begin{array}{l}\gamma(\text { yaa }) \text { ninuu } \\
\text { (oa) mu }\end{array}$ \\
\hline 3 & ni & (i) $\mathrm{ni}$ & niye & (i) ni & ni & (ia) ni \\
\hline incl. 1 & $\int \mathrm{did}, \mathrm{din}$ & (it) did, (it) din & S ninde & (kitnin(d) & (dida, did & (ita) dida \\
\hline excl. 1 & Pmam & ( (am) mam & ? mami & (kammam & (mami, mam & $\begin{array}{l}\text { (am) mami, } \\
\text { ammami }\end{array}$ \\
\hline P1. 2 & bir & (im) bir & mire & kimmir & bir & (mia) bir, mibir \\
\hline 3 & rir & (hir) rir & nire & sinir & rir & (ira) rir. irrir \\
\hline
\end{tabular}

47) Ter vereenvoudiging van de lectuur moge de volledige analyse hier enkel in een noot volgen.

In de eerste persoon is $\dot{n} u, n u, \dot{n}, n<* \dot{n}\lrcorner k u<<_{n}-k u$. Hier vindt men dus het teken $* k u$ terug, dat we reeds herhaaldelijk in deze persoon hebben ontmoet. De nasaal kenmerkt het uitdrukkelijk als genitief. In de tweede persoon is jamdena nime, nim <*ni-mu; in de derde persoon niye $<^{*} n i-a$. Dit zijn dus eveneens bekende oude tekens. Bij de versterkte vormen zijn telkens de personalia voorgevoegd. Hun gebruik is echter facultatief. In het meervoud is de bouwtechniek aanmerkelijk meer gecompliceerd. In de eerste persoon inclusief zal men wel van een reduplicatievorm moeten uitgaan, zoals ook zeer wel bij de betekenis past. De $d$-vormen zijn hier ontwikkeld uit een prenasalering van de oorspronkelijke ${ }^{*} t$-vormen. Men krijgt dus ${ }^{*} d a-i-(n) t a,{ }^{*} d a-i-d a>d i n$, dida, did. In het jamdena

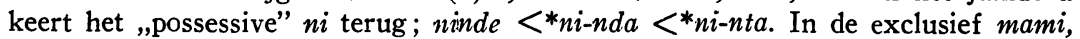
$m a m<* m a-m i$; opnieuw dus weer bekende elementen uit de reconstructie van hierboven $(9 \mathrm{vv}$.$) . In de tweede persoon meervoud is aan het oorspronkelijke *_{m i}$ (nevenvorm ${ }^{*} b i$ ) het teken $r<r i<r a$ toegevoegd. Dit stamt uit de naburige derde persoon, maar heeft algemene meervoudige betekenis gekregen. In verscheidene verwanten talen is hetzelfde gebeurd $\left.{ }^{*}\right)$. ${ }^{*} M i-r a,{ }^{*} b i-r a>$ mire, bir. In de derde persoon meervoud in het kei en het fordata heeft men weer een reduplicatievorm; rir <*ra-i-ra. Maar in het jamdena weer het „possessive”; nire $<*_{n i-r a}$. $\mathrm{Bij}$ de versterkte vormen leveren de samentrekkingen met het personale geen moeilijkheden op. Typisch is alleen de tendens tot samensmelting, die daarbij soms optreedt, speciaal in het jamdena.

*) cfr. H. Geeroms, Over de derde persoon meervoud in het austronesisch, BTLV 102 (1943), 51. Zie ook hierachter 42 vv., 52 vv., 55 vv. en reeds hiervoor 11. 
Naast voorbeelden van dergelijke ingewikkelde incrustatie- of kristalliserings-processen vindt men er in de Ambon-Timortalen echter ook wel andere van veel eenvoudiger aard. Zo passen het timorees en het koepang, twee van de meest westelijke leden der groep beide nog regelmatig de oude nominale tweedeling toe. Van ,possessives” is daarbij echter geen spoor te bekennen. De inalienabilia suffigeren eenvoudig de oude tekens, en voegen vòòr het nomen de corresponderende personalia toe. De alienabilia doen enkel het laatste. Men heeft b.v. koepang au mata- $\dot{n}-a$,mijn oog” maar au uma-la „mijn huis” ( $a$, la zijn artikels).

Het rottinees kan in dit verband niet van het timorees en het koepang gescheiden worden. De aanduidingstechniek is in beide gevallen volkomen dezelfde. Daarenboven schemert de oude tweedeling in deze taal op allerlei punten nog duidelijk door, ook al wordt deze in de huidige taalphase niet meer regelmatig weergegeven. Zo kan het vooropgeplaatste personale b.v. wegblijven, naar Prof. Jonker's mededeling, bij woorden, die een familiebetrekking aanduiden, met name in de eerste persoon enkelvoud. Hetzelfde geldt ook voor de namen van lichaamsdelen. Voor derde persoonsvormen in genitivische of adverbiale functie gelden nog enkele speciale regels ${ }^{48}$ ). Bij deze oeroude groepen die we thans reeds zo vaak hebben ontmoet, bezaten de oude suffixen dus blijkbaar nog determinerende kracht genoeg uit zichzelf. Een bijzondere versterking, die daarenboven van een geheel andere taalstijl getuigde, was hier niet nodig. Men heeft b.v. sè laök lò ò? Ama-nga ma ana-nga (en niet *au ama-nga) ,Wie gaan met u?” „Mijn vader en mijn zoon”. Dòpe-a hina lima-ma (en niet *o lima-ma) „Het mes heeft uwe hand gewond".

Anderzijds dient men zich echter wel bewust te zijn van de consequenties, nu de oorspronkelijke nominale tweedeling in het rottinees goeddeels is weggevallen. De oude suffixen krijgen daarmede in principe zelf rechtstreeks-genitivische waarde. Zou men dit voor deze taal zelf nog niet geheel willen toegeven, omdat hier de personalia nog altijd in de meeste gevallen als versterking optreden, dan geldt deze conclusie in ieder geval wèl ten volle voor naburige talen als bimanees en soemba, die niet meer tot de Ambon-Timorgroep behoren. De personalia hebben hier met de genitivische constructie niets meer te maken, en van nomi-

48) J. Jonker, Rottineesche Spraakkunst 347 vv. 
nale klassificatie valt geen spoor te bekennen. Wat zich hier ontzeikkelt, is m.a.w. juist het west-indonesische standpunt. De possessieve tekens staan achter het nomen, op de plaats der oude inalienabilia. Maar ze hebben algemene casuswaarde. De serie luidt b.v. in het rottinees sg. 1. $-k<-k u$; 2 . $-m<-m u$; 3. $-n<-n a$; pl. 1. incl. $-t<-t a$; excl. $-m<-m a ; 2 .-m<-m i ; 3$. $-n$ uit $3 \mathrm{sg}$. Men ziet, hoe vlot en regelmatig de reconstructie hier verloopt.

Juist het omgekeerde eindpunt van de ontwikkeling is bereikt in het ngad'a van West-Flores, waar thans eveneens de oude tweedeling verdwenen is. Hier treden enkel personale elementen als possessieve tekens op, en nu is juist van de oude suffixen niets meer te merken! Wat oorspronkelijk enkel als versterking en verduidelijking telde, is geëindigd met de alleenheerschappij te verwerven! Des te karakteristieker is het daarom, dat de plaats der personale tekens thans nog juist zo wisselt als vroeger voor de alienabile en de inalienabile tekens gold. Dit wijst er toch wel op, dat ook hier het gevoel voor de oude indeling slechts pas betrekkelijk kort uit het taalstelsel verdwenen kan zijn. Men ziet de feiten in P. Arndt's grammatica ${ }^{49}$ ).

\section{c. Het indringen van de personalia in het possessieve systeem.}

De belangrijkste ontwikkelingslijn van het possessieve systeem, waarvoor men komt te staan in de Ambon-Timorgroep, is echter de langzame doch onweerstaanbare infiltratie van het personale. Tot zelfs de materiële vorm der oude tekens kan daarbij worden aangetast, zo hebben we reeds gezien.

Men kan deze ontwikkeling van structureel standpunt ook gemakkelijk begrijpen. Het nieuwe begrip ,,bezit” berust bij slot van rekening, zoals reeds is uiteengezet, op een scherper stratificatie van de menselijke persoon. De kern daarvan komt op de duur uitdrukkelijk als het meerwaardige deel naar voren. Maar op het menselijk ,ik" wijst in de taal nu juist speciaal het personale. Het possessivum daarentegen noemt het bezit, dat thans meer dan ooit als secundair en afgeleid geldt. Zo is tenslotte zelfs de uiterste uithoek van het possessieve stelsel niet veilig gebleven voor de invloed van het personale.

Karakteristiek is nu vooreerst, dat ook het personale, op enkele uitzonderingen na, weer uitsluitend vòò aan het woord wordt toege-

49) P. Arndt, Grammatik der Ngad'a-Sprache, VBG 72, derde stuk; 5. 
voegd, dat wil dus zeggen op de plaats der oude alienabile tekens. Hier was de bodem voor het nieuwe begrip inderdaad ook het beste voorbereid. Aan de andere kant was de plaats vooraan het woord in het oude systeem echter reeds druk bezet. Men had hier èn de ,possessives" èn de oude personale tekens. Met het personale mee, ontstaan hier dus nu in totaal drieledige constructies! Dit is wel wat veel, vooral als men bedenkt, dat zowel de nieuw toegevoegde personalia als de oude vormen van het type $*_{k u} ;{ }^{*} m u ; *_{n a}$ enz. telkens persoon voor persoon van gedaante veranderen! Zo dreigt zeker allerwege onzekerheid en verwarring. En het gevolg is, dat men in de verder ontwikkelde talen overal naar vereenvoudiging is gaan streven. De dubbele conjugatie wordt opgeheven. En natuurlijk is het weer de zwakste van de twee die daarbij moet wijken, d.w.z. die van de oude tekens achter het „possessive”. In verreweg de meeste gevallen wordt hier daarom de derde persoonsvorm, die de meest frequente is en die ook de meest algemene betekenis heeft, aan het woordeinde eenvoudig veralgemeend ${ }^{50}$ ). Soms kiest men ook wel een veel radicaler weg, en komt de suffixrij ineens als geheel te vervallen. En op één van deze beide wijzen is dan weer het normale evenwicht tussen functie en vorm hersteld. Alleen, van de vroegere lijnen is onderwijl niets meer overgebleven. De aanvankelijk geldende oer-austronesische stijl is totaal gewijzigd....

Men kan in geheel het ontwikkelingsproces een aantal phasen onderscheiden :

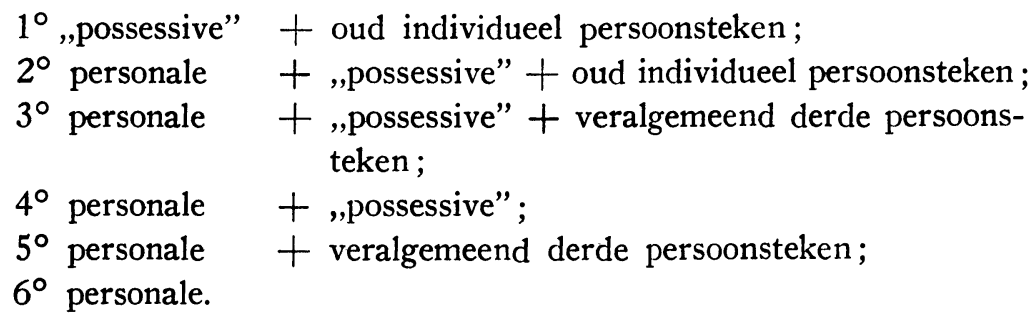

Voor de eerste phase, die niets anders voorstelt dan de oeroude melanesische vormstijl, zagen we in Indonesië reeds een voorbeeld in het slaroe.

Voor de tweede phase kan men wijzen op het boeli, een der talen van Zuid-Halmahera, die vooral door Dr. N. Adriani bestudeerd is ${ }^{51}$ ).

50) Zie ook hierachter $51-56$.

51) N. Adriani- A. C. Kruyt, De Bare'e-sprekende Toradja's van MiddenCelebes, III (1914), 309-35. 
De toevoeging van het personale is hier reeds algemene regel geworden. $\mathrm{Bij}$ de inalienabilia komt de nieuwe index vòò het nomen te staan, bij de alienabilia voor de beide ,possessives” $n i$ en $n a$ die in de taal nog volkomen intact zijn. Dit geldt echter alleen voor het enkelvoud. In het meervoud zijn de oude elementen $* m i$; $*_{t a}$ enz. reeds geheel verdrongen door de personalia, of althans door elementen die zich nauw daarbij aansluiten.

Men heeft b.v. ja boboko-k; a boboko-m; $i$ boboko ,mijn (jouw, zijn) hoofd", maar ja-ni-k ebai; a-ni-m ebai; $i$-ni ebai ,mijn (jouw, zijn) huis" en eveneens ja-na-k-pinge; a-na-m-pinge; i-na-pinge „,mijn (jouw, zijn) rijst". In het meervoud echter ame boboko-mam; me $(u)$ boboko-meu ,ons (excl.), jullie hoofd" maar a-ni-mam ebai; me-ni-meu ebai „ons (excl.), jullie huis" en a-na-mam pinge; me-na-meu pinge „ons (excl.), jullie rijst”. Men ziet uit deze enkele voorbeelden reeds hoe een dergelijk stelsel bijna evenveel ,afwijkingen” en ,uitzonderingen” telt als ,regels”. De dubbele conjugatie der persoonselementen leidt natuurlijk onvermijdelijk tot allerlei ontwikkelingsstoornissen.

De derde ontwikkelingsphase wordt duidelijk vertegenwoordigd door een ander oostelijk lid der Ambon-Timorgroep, nl. het nufoor, de taal der Schouten-eilanden en van het aangrenzend deel van NieuwGuinea ${ }^{52}$ ). Als enig ,possessive” is hier in gebruik be. Daarvóór staat het personale, of een daarvan afgeleide vorm; daarachter $-d i$ of $-d a$, naargelang het nomen regens de naam van een persoon of dier, ofwel van een inanimatum is. Deze beide laatste vormen kunnen echter onmogelijk worden gescheiden van het zelfstandig personale van de derde persoon dat hier $d e$ luidt (ook wel $i$ ); proclitisch idem ( $i d$-an „hij eet”) ; vgl. Liambata (Seran) proclitisch $3 \mathrm{sg}$. di-; Jotafa personale 3 sg. de-r enz. Het derde persoonsteken is hier dus in het volle paradigma als suffix veralgemeend. Aan de moeilijkheden der tweede phase is daarmede in beginsel een einde gekomen. Geheel consequent is de nieuwe drieledige bouwtechniek in het nufoor echter nog niet doorgevoerd. Men kan ook nauwelijks anders verwachten. Een dergelijke veelomvattende omvorming, waarbij allerlei vanouds gewende wegen en distincties door andere moeten worden vervangen, vraagt uiteraard lange tijd.

Ook op een ander punt past het nufoor niet geheel in het zoëven

52) F. van Hasselt, Spraakkunst der Nufoorsche taal, 1905. 
geconstrueerde theoretische schema. De possessieve constructietekens staan hier n.l. zowel bij de alienabilia als bij de inalienabilia, achter het nomen. De meest waarschijnlijke verklaring is wel, dat de taal op deze wijze een tegenwicht heeft willen scheppen tegen de oversterke vernieuwing die ze op andere punten te zien geeft. Wat de plaatsing der tekens betreft, domineert thans de ,inalienabile stijl”, zoals op andere punten die der alienabilia de leiding heeft genomen. Zo blijft althans enig overwicht in het stormachtig ontwikkelingsrythme bewaard.

Men heeft b.v. bij de hoogste waarderingsklasse der alienabilia $1 \mathrm{sg}$. -yedi $<$ ya-di (zonder "possessive"); 2 sg. -bedi $<$ be-di (zonder personale); 3 sg. -byedi $<i$-be-di; 1 pl. -kobedi, -nubedi, -kubedi $<$ $k o(n u, k u)-b e-d i ; 2$ pl. -mgobedi, -mubedi $<m g o(m u)-b e-d i ; 3$ pl. -subedi $<$ su-be-di; -sedi < si-di (zonder ,possessive").

Juist omdat de alienabile tekens in het nufoor achter het woord staan, is het contact met de inalienabile rij hier veel inniger dan gewoonlijk elders het geval is, waar de ene rij vòòr het woord maar de andere daar achter staat. Zo wordt het begrijpelijk, dat in het nufoor zelfs ook bij de inalienabile vormen het verstarde derde persoonsteken als algemene index optreedt ${ }^{53}$ ). De vorm luidt $-r i$. Men heeft b.v. mgo $k m a-s-r i$, ulieder vader" $(s<s i$, nevenvorm van $r i$, is hier het pluralisteken) ; sba-m-b-ri „uw moeder” ( $b$ overgangsklank). Men ziet hoe $r i$ hier volkomen is verstard; het stoort zich niet in het minst meer aan de oude grenzen tussen de verschillende persoonskategorieën. Men vindt $r i$ overigens ook in nominaal gebruik; kama-ri „vader-zijn” is b.v. algemeen ,vader, iemands vader, een vader" gaan betekenen. Wil men uitdrukkelijk ,,mijn vader" zeggen, in tegenstelling tot de vader van iemand anders, dan moet achter kama-ri nog yedi gevoegd worden, zo deelt van Hasselt mede. Kamari yedi, kma yedi. De vorm yedi is echter een alienabel teken, naar we reeds weten. Een duidelijker bewijs, dat bij al de intredende veranderingen ook de oude distinctie tussen de beide vormen van ,possessie" in het nufoor het nodige heeft geleden, kan men wel niet verlangen!

Voorbeelden van de volgende phasen $4-6$ vindt men iets meer naar het westen, vooral in een aantal talen van Flores, Timor en onderhorigheden. Gewoonlijk komen hier meerdere vormingswijzen naast elkander voor, waardoor de voortgang in de ontwikkeling duidelijk

๒3) Zie ook hierachter 51 vv. 
uitkomt. Zo staan de constructies van het kisser bij beide groepen als regel nog in de tweede phase. Maar in het niet zover verwijderde galoli ziet men de suffixale vervoeging in analoge omstandigheden al verstarren. Alle meervoudige personen gaan hier b.v. in de alienabile constructie reeds uit op $-r<-r a$, dat van de derde persoon stamt ( $3 \mathrm{e}$ phase). In de tweede persoon enkelvoud wordt geen teken meer toegevoegd aan het ,possessive” $n i$ (4e phase). In de eerste persoon enkelvoud daarentegen keert echter weer $-n$ terug, dat van de derde persoon afkomstig is (3e phase). Vanaf de derde persoon enkelvoud staan de possessieve constructies hier daarenboven regelmatig achter het woord, juist zoals we dat zoëven in het nufoor hebben gezien, en blijkbaar om dezelfde reden. Men ziet, hoe vloeiend het taalstelsel is op al deze punten! Bij een vorm als lima-n ,hand”, dat hier ook alienabel kan worden vervoegd (een verschijnsel dat op zichzelf al markant genoeg is), heeft men b.v. gạu ni-n (ook ga ni-k) liman „mijn hand”; go ni liman , jouw hand"; lima ni ni-n ,zijn hand”; lima gita (gami, mi, sia) ni-r ,onze (uwe, hun) hand”.

Het galoli „possessive” $n i$ is naar alle waarschijnlijkheid zelf ook afkomstig uit de derde persoon. Men zou een constructie als 2 sg. go ni liman ,jouw hand" daarom, strikt genomen, evengoed kunnen onderbrengen bij de vierde als bij de vijfde phase. Er zijn echter ook wel talen, waarin men deze beide phasen duidelijk van elkander kan onderscheiden. Zo treedt b.v. in het tettum van midden-Timor, waar thans geen nominale tweedeling meer bestaat, in de indonesische onderafdeling Belu het substantief $k a \vec{n}$,,bezit” als "possessive” op, maar in Dilli op portugees terrein vindt men daarvoor in de plaats het pronomen $3 \mathrm{sg}$. nia. Verder wordt hier, althans in sommige gevallen, alleen het personale gebruikt als possessieve aanduiding. Dit is dus het eindpunt van de gehele ontwikkeling, onze phase 6 . Iets dergelijks hebben we hierboven ook reeds in het ngad'a van Flores gezien (40). Het luidt b.v. nia kān matan ,zijn oog” (Belu, vierde phase), maar ninia (nia-nia) matan ,id”. (Dilli, vijfde phase); hau oan; o oan „mijn (jouw) kind” (zesde phase).

Hoe gevaarlijk de hier beschreven ontwikkeling is voor de oude persoonstekens, is zonder meer duidelijk. De bedreiging komt zowel van de buitenkant, door de analogie van de corresponderende personalia, als van binnenuit, door het indringen van de derde persoonsvorm. Het einde kan onder zulke omstandigheden niet twijfelachtig zijn. En zo 
zijn de tekens van het type $*_{k u} ; *_{m u ;} *_{n a}$ b.v. in het sikka en solor van Flores, tegelijk met de nominale tweedeling, geheel verdwenen. Slechts in weinig talen komt de ontwikkeling zo ver. Daarvoor in de plaats getreden zijn vormen, bestaande uit het personale met een suffix (solor $-n$; sikka $-n$ ), dat zoals zo vaak oorspronkelijk uit de derde persoon stamt. Ook nu staat de gehele constructie overigens weer achter het nomen. Het welbekende compensatieverschijnsel, dat in deze ultraradicale omgeving waarlijk ook wel op zijn plaats is!

\section{B. De plaats van de genitief.}

Aangaande de plaats van de genitief bestaat er in de indonesische vakliteratuur juist zulk een twistpunt als we zoëven betreffende de nominale tweedeling hebben gezien. Brandes nam aan, dat er in de oerindonesische grondtaal voor het nomen regens vrijheid van plaatsing had bestaan, maar achtte aan de andere kant de daardoor ontstane verschillen toch zo gewichtig, dat hij enkel op die grond de meer oostelijke talen met vooropplaatsing als een aparte ,afdeling” stelde tegenover de meer westelijke talen met postpositie ${ }^{54}$ ). W. Schmidt daarentegen hield de postpositie voor algemeen-austronesisch, en dus ook voor oer-indonesisch. De vooropplaatsing in de oostelijke talen berust volgens hem enkel op de invloed van het alhier bijzonder werkzame papua-substraat ${ }^{55}$ ). Ook Jonker beschouwt de vooropplaatsing van het Oosten als secundair ${ }^{56}$ ). Deze zou zich z.i. echter op grond van een innerlijk evolutieproces uit de oer-indonesische postpositie hebben kunnen ontwikkelen. En met name zou de analytische genitiefconstructie met pronominaal suffix, die in de Ambon-Timorgroep veel voorkomt, daarbij als brug hebben gediend (type timor in mata-n oe-n

54) J. L. Brandes, Bijdrage tot de vergelijkende klankleer der westersche afdeeling van de maleisch-polynesische taalfamilie. Utrecht 1889; 20 vv.; Stelling II en III, 156 noot, 173 noot 2; -, Toelichting tot de schets-taalkaart van Celebes (Not. Dir. Verg. Bat. Gen. dl. 32, 1894), 17 en 18; N. Rinncoy, Maleisch-kissersche Woordenlijst, met inleiding van J. Brandes, Tijdschrift Bat. Gen. 31 (1886), 150 noot 3; N. Adriani- A. C. Kruyt, De Bare'e-sprekende Toradja's van Midden-Celebes, op. cit. 287.

515) W. Schmidt, Die sprachlichen Verhältnisse von Deutsch-Neuguinea ZAO(O)S 6 (1902), 88-93. Zie ook -, Die sprachlichen Verhältnisse Oceaniens in ihrer Bedeutung für die Ethnologie, MAGW 29 (1899), 250.

56) J. Jonker, Kan men bij de talen van den Indischen Archipel eene westelijke en eene oostelijke afdeeling onderscheiden? VAWA 4e reeks, 12e deel (1914), 314 vv. ; - Rottineesche Spraakkunst, op. cit. 270-74. 
„hij oog-zijn vocht-zijn” = zijn traan; kupang $a u b o-\dot{n}$ sè-n ,ik hoofdmijn been-zijn (ervan)" = mijn schedel). Kanski en Kaprusch tenslotte opperen methodologische bezwaren tegen de argumentatie van Brandes en Jonker, en verkiezen dan ook op dit punt de theorie van hun leermeester W. Schmidt ${ }^{57}$ ).

Het beslissende punt in dit verband is hierin gelegen, naar het ons voorkomt, dat de localiseringen van de genitief vòò of achter het nomen regens ook in dit geval blijkbaar elk bij een geheel andere orde van zaken behoren. Aan het vormverschil beantwoordt hier m.a.w. ook een zeker algemeen structureel verschil. De vooropplaatsing drukt oorspronkelijk speciaal de „echte” possessie uit, d.w.z. wat we hierboven het nieuwe begrip ,bezit" hebben genoemd $(22,33)$. Dit laatste punt duidelijk te hebben bewezen, is o.i. de grote verdienste van Jonker's scherpzinnige verhandeling van 1914. Onze overeenkomstige analyse op grond der pronominale feiten krijgt daarmee van zulk een deskundige zijde een welkome bevestiging. Zo spreekt de hoogleraar b.v. van „,de nagenoeg volkomen regelmaat van die gevallen, waarin het bepalende lid (aan het bepaalde) vooraf gaat”. „(Zelden) of nooit”, zo gaat hij verder, ,is (bij een dergelijke constructie) de waarde geen zuiver possessieve, en waar dit al een enkele maal het geval mocht zijn, daar is mij tenminste geen enkele bekend, welke in meerdere dezer talen in gelijken vorm voorkomt” (355). „De eigenlijke genitiefconstructie”, zo luidt het ook in een latere passus, ,kan alleen voorkomen, waar sprake is van een echten genitief (een possessieven, soms een partitieven of subjectieven genitief). En ook in de samenstelling kan, als regel, het bepalend woord alleen vooropstaan, waar het de waarde van een echten genitief heeft. Waar dit niet het geval is, staat het bepalende woord achteraan" (330 v.).

De vraag is nu dus maar, wat de andere pendant van het stelsel, d.w.z. de achtervoeging van de genitief, speciaal bedoelt weer te geven? Welke nuance is hier dominant? Naar het ons wil toeschijnen, kan het antwoord op deze vraag niet twijfelachtig zijn. We vinden hier juist dezelfde verhoudingen terug, die we hierboven reeds als ,inalienabel” hebben aangeduid. De gepostponeerde genitief drukt vrijwel steeds een zeker „zo-zijn” van het nomen regens uit. Zo vindt men in het jamdena

57) P. Kanski und P. Kaprusch, Die indonesisch-melanesischen Uebergangssprachen auf den Kleinen Molukken, Anthropos 26 (1931), 883-90. 
regelmatig constructies als de volgende met de genitief achterop: ian kewas ,vis rivier" = vis uit de rivier, riviervis ; bab jalas ,varken bos" = een varken uit het bos, een bosvarken; kakoetoen dole ,hout uitheems (oostelijk)" = hout uit den vreemde, import-hout; das timbe "huis bamboe" = een huis van bamboe. Men ziet hoe hier telkens bijzonder intieme verhoudingen worden genoemd: het milieu waarin het nomen regens gewoonlijk verkeert, het materiaal waaruit dit vervaardigd is, het doel waarvoor dit dient, de omstandigheden die daarbij altijd zo zijn enz. Wordt echter ,een grammatikaal bezit” uitgedrukt, zo verzekert $\mathrm{P}$. Drabbe, dan staat de genitief voorop en wel in een partikelconstructie; das ni fofolat "huis zijn deur" = de deur van het huis ${ }^{58}$ ).

Vrijwel dezelfde scheidingslijn vindt men ook terug in twee overigens zo ver van elkander staande talen als het buru en het nufoor. Wordt een verhouding van bezit uitgedrukt, dan staat het nomen rectum hier voorop, in het tegenovergestelde geval achterop. Buru wai-foi ,water om te baden" = badwater; wai-ino ,water om te drinken" = drinkwater; kau-bana ,hout om te branden" = brandhout; geba-fuka ,mens van de bergen" = bergbewoner; géba-enhain "mens van de golven” = zeeman ; fahan bali ,hand van de linkerzij” = linkerhand. Maar nizue-pun „klapperboom" = de boom van de klappers, klapperboom; fuat-pun ,pisang-boom" = de boom met de pisangs, pisangboom; fuhan-zeai ,bron water" = water uit een bron; wai-fuhan ,water bron” = de bron met water, de waterbron. Maar ook kadan-lalen ,,voet zool" = de voetzool ; fahan lalen ,hand zool" = de handpalm; olon-folon „hoofd haar" = het hoofdhaar ; fifin-folon ,mond haar" = snor. Men ziet uit deze laatste voorbeelden, die $\mathrm{H}$. Hendriks ten onrechte geheel met de voorgaande op één lijn heeft gesteld, dat de oorspronkelijke distinctie hier dus reeds aan het wankelen is ${ }^{59}$ ). Vgl. juist zo ook jamdena tomreate lima-n ,,mens hand-zijn” $=$ de hand van de mens. Men zou hier postpositie van de genitief verwacht hebben, in verband met de aard der inalienabile verhouding.

Ook in het rottinees vindt men nog enkele fraaie inalienabile kategorieën met postpositie. Zo staat hier b.v. steeds achteraan het substantief waarmee men een vergelijking, het zo-zijn in de verbeel-

58) P. Drabbe, Spraakkunst der jamdeensche taal, op. cit. 18 v.

59) H. Hendriks, Het burusch van Màserète, 's Hage 1897; 6 v. 
ding dus, noemt. Babaü kapak ,vlinder karbouw” = een vlinder als een karbouw, een reuzenvlinder. Juist zo ook mat mio ,oog kat” = met het oog als dat van een kat, katogig. Ook de stofaanduidingen worden in het rottinees weer regelmatig gepostponeerd. Uma batu „huis steen” = een huis van steen, een stenen huis; tutui nitu ,verhaal over spoken" = spookverhaal; lelesu uma "deur aan het huis" = huisdeur; lelesu lalae „staldeur” (maar lalae-a lelesu-na ,id.” $\left.{ }^{60}\right)$ ).

Sporen van strijd tussen de oude en de nieuw-opgekomen tendenzen vindt men in de oostelijke talen b.v. in het kei en in het ngad'a van West-Flores. In het kei heeft de nieuwe genitiefkategorie schijnbaar reeds ten volle getriomfeerd. De vooropplaatsing van het nomen rectum, de westelijke stijl dus volgens Brandes, is daarbij algemene regel. De verbinding met het nomen regens wordt met een speciaal partikel $n i$ bezegeld. In gevallen van ,een zeer nauwe betrekking, welke in het Hollandsch meestal door een samengesteld woord wordt weergegeven", zo deelt P. Geurtjens mede, wordt ni nu echter ineens weggelaten. Zou men hierin geen halve herleving van de oude als inalienabel gevoelde sfeer mogen zien? Verder staat hier speciaal bij de plaatsnamen het nomen rectum nog achter. Zou ook dit niet samenhangen met de oude inalienabile aanvoeling, zo vraagt men zich af. Nit uun ,lijk hoofd" = doodshoofd; wāv janan ,varken kind" = big; maar rahan ni fid ,huis zijn deur" = de deur van het huis; rāt $F \bar{a} n=$ de radja van Fan; tanat Eiwāv = het land van $\mathrm{Kei}^{{ }^{61}}$ ).

In het ngad'a kan het nomen rectum zowel vóór als achter het regens worden geplaatst. Dat attributieve aanduidingen en speciaal stofnamen daarbij de laatste plaats verkiezen, verwondert ons niet. We hebben dit in de verwante talen reeds herhaaldelijk gezien. Wel opmerkelijk is echter, dat de plaatsing voorop, naar de omschrijving van P. Arndt, vooral frequent is ,wenn es sich um Körperteile, Eigenschaften, Tätigkeiten oder Kleidungsstücke des Subjektes handelt". Enige van deze kategorieën zijn van oeroude inalienabile oorsprong, en men zou deze daarom eerder achter het regens hebben verwacht. Blijkbaar heeft het oorspronkelijk verband in het ngad'a echter al een deel van zijn kracht verloren. Aan de andere kant kan de

60) J. Jonker, Rottineesche Spraakkunst 271 vv. Andere sporen van de oude inalienabile kategorie in het rottinees zagen we reeds hierboven p. $39 \mathrm{v}$.

61) H. Geurtjens, Spraakleer der Keieesche taal 10. 
plaatsing voorop van de speciaal juridisch-possessieve genitief zich hier alleen doorzetten, wanneer de vorm door bijzondere partikels, waarvan er soms twee of drie op elkander worden gestapeld, wordt versterkt. Juist hier slaagde de nieuwe vorm in andere talen het eerst, naar we reeds weten. De reactie der oude postpositie moet in het ngad'a dus wel bijzonder sterk geweest zijn. Anders was de overwinning wel gemakkelijker en sneller behaald. Cana xaki go xabo veki gazi „die Kleidung des Mannes” (cana xaki „Mann”; go partikel); maar evengoed met steeds stijgende nadruk dzara go radza; dzara ngata radza; dzara go ngata radza „das Pferd des Königs” ${ }^{2}$ ).

Men ziet de conclusie, waartoe al deze series van voorbeelden als vanzelf leiden. Het is wel duidelijk, dat de verplaatsing van de nominale genitief in de oostelijke indonesische talen onverbrekelijk samenhangt met die van de pronominale possessietekens, die we hierboven reeds behandeld hebben. In de grond gaat het hier blijkbaar over één en dezelfde structuurverandering, en vandaar dat zowel de semantische als de morphologische details in beide gevallen zo nauwkeurig overeenstemmen. Dat de postpositie van de nominale genitief ouder is dan de plaatsing voorop, volgt daaruit vanzelf. De gewone opinie in dit opzicht is dus zeker juist. Van meer gewicht echter is, dat nu tegelijkertijd ook blijkt, welke betekenis de later ingetreden verschuiving had. Men ziet a.h.w. welke taalkundige en structurele belangen daardoor werden gediend. Dat de plaatsing van het nomen rectum vroeger vrij was, zoals Brandes aannam, is o.i. niet waarschijnlijk. Dat de latere verschuiving een blind-mechanisch karakter droeg, zoals de infiltratie- of substraattheorie van W. Schmidt en zijn leerlingen min of meer met zich meebrengt, evenmin. De taalontwikkeling pleegt op dergelijke momenten door een duidelijke teleologie geleid te worden. We hebben daarover in ander verband reeds gesproken (33). $\mathrm{Nu}$ is ons de oorzaak van de verplaatsing der pronominale persoonstekens hierboven al duidelijk geworden. Het persoonsbeeld komt scherper naar voren in de latere phase der taalstructuur, zo hebben we gezien. En speciaal voor de typische verhouding tussen de kern en de peripherie daarvan, die ,bezit” genoemd wordt, ontstond op de duur in de taal een eigen vorm van aanduiding. Blijkbaar is nu secundair hetzelfde diepere reliëf ook bij de nomina uitgedrukt, en ook de

02) P. Arndt, Grammatik der Ngad'a-Sprache, VBG 72, 3, 18 vv.

Verh. dl. XII. 
nominale genitief werd daarom voortaan vóór het nomen regens geplaatst.

Tot welke gewichtige consequenties deze laatste veronderstelling precies leidt, wordt ons pas geheel duidelijk, wanneer men tegelijkertijd ook in aanmerking neemt, dat de pronomina in talen als de indonesische practisch vrijwel uitsluitend op menselijke personen wijzen. De pronominale anaphora is hier zeer gering van omvang. De enkele gevallen dat b.v. dieren in de volksverhalen sprekend optreden en dan met een persoonsteken worden aangeduid, kunnen gevoeglijk met die van handelende en sprekende menselijke figuren worden gelijkgesteld. Kort samengevat luidt onze conclusie dus, dat de nieurve genitiefkategorie in de indonesische talen het eerst bij de namen van menselijke personen een eigen vorm heeft gevonden. De namen van andere grootheden zijn pas secundair bij dit proces betrokken geraakt ${ }^{63}$ ).

Men kan zich deze typische gang van zaken, practisch en structureel, zeker ook wel indenken. Het bezit is zonder twijfel een kategorie, die een duidelijke gradatie van aandacht en waardering in zich draagt, en die ook herhaaldelijk vrijwel onvermijdelijk in de taal om een aanduiding vraagt. Waar kon het daarenboven eerder nodig worden, ,het bezit" ook als zodanig in de taal weer te geven, dan waar de mens zelf de oppermachtige ,bezitter" was? Bij welk beeld heeft de spreker eerder belang dan bij dat van zijn eigen onvergelijkelijke persoon? Zo wordt het dus ook begrijpelijk, dat in het algemeen genomen de pronominale feiten bij dit zeer complexe ontwikkelingsproces ook een véél meer uitgesproken karakter dragen dan die bij de nomina. De tekening der nieuwe genitiefkategorie is hier meer expliciet. Een extreme situatie als b.v. in het ngad'a waar van de oude pronominale suffixen eenvoudig geen spoor meer is overgebleven, heeft zich bij de nomina, voorzover de gegevens thans reiken, nooit voorgedaan ${ }^{64}$ ).

Het is de eerste maal, dat we hier, eenvoudigweg door de gang van

63) In een aantal afrikaanse talen vindt men juist hetzelfde. J. Wils, De nominale klassificatie in de afrikaansche negertalen, op. cit. 159-162. Vgl. ook de rede van $M$. Deutschbein op het derde internationale Linguistencongres te Rome (1933).

64) W. Schmidt schijnt van mening te zijn, dat de vooropplaatsing van de genitief bij de nomina ouder is dan die bij de pronominale tekens. Voor het laatste geval spreekt hij althans van „Konsequenz”. Een motivering van zijn mening geeft hij verder echter niet, - Die sprachlichen Verhältnisse von Deutsch-Neuguinea, Zeitschrift für afrikanische, oceanische und ost-asiatische Sprachen 6 (1902), 16. 
onze analyse geleid, de menselijke persoon zèlf als belangrijke factor in de indonesische taalgeschiedenis ontmoeten. De laatste maal is dit echter niet. Het is voortdurend, alsof de menselijke figuur hier achter de taalfeiten verrijst, telkens als men maar enigszins dieper daarop ingaat. Het taalsysteem der indonesische talen draagt in het algemeen wat men een ,personalistisch" karakter zou kunnen noemen. Juist de menselijke persoon komt hier voortdurend, direct of indirect, naar voren. Is deze het zelf niet, die een bepaalde exclusieve positie inneemt, dan is deze kategorie toch in veel gevallen, zoals ook hier bij de constitutie van de genitief, de oorspronkelijke kern geweest, waarlangs zich pas secundair de expansie verder ook naar andere groepen van vormen heeft verspreid. We zullen hieronder nog verschillende voorbeelden van deze merkwaardige en opvallende trek zien. Hoe men ook over de verhouding van de verschillende austronesische ondergroepen denkt, vast staat in ieder geval, naar het ons voorkomt, dat het voor een goed deel een nieuw beeld en een nieuwe positie van de menselijke persoon zèlf geweest moeten zijn, die van het oer-austronesisch langzamerhand het oer-indonesisch hebben gemaakt. Het individu moet bij de volkeren van de archipel in vergelijking met het vroegere alles-beslissende clanverband hoe langer hoe meer aan betekenis hebben gewonnen. Het indonesische taalstelsel is niet alleen door de mens, maar structureel gesproken voor een overwegend deel ook áán hem ontworpen en gevormd ${ }^{65}$ ).

\section{De constitutie van een algemene onpersoonlijke vorm bij de inalienabilia.}

We hebben hierboven duidelijk de doorbraak van de nieuwe genitiefkategorie kunnen volgen, dwars door het oude stelsel der ",possessie”klassen heen. Bij de alienabile kategorie was de weerstand het geringst, omdat de verwantschap met het nieuwe hier het grootste was. Wat gebeurt er nu echter met de groep der inalienabilia? Dringt ook hier de genitief in? En wat is speciaal het lot der persoonstekens, die hier steeds achter de nominale stam werden geplaatst? Dat hier een aanmerkelijke functieverzwakking moet zijn ingetreden, is duidelijk.

65) L. Brunschvicg, De la connaissance de soi, Paris 1931, 77-94; Ch. Rogge, Selbstbewusztsein und Sprache, Archiv für die ges. Psychologie, Bd. 87 (1933), 299 vv. 
Waartoe heeft deze echter practisch geleid? Er zijn allerlei mogelijkheden in dit opzicht in het taalleven. Welke van deze is nu in de archipeltalen gerealiseerd?

\section{a. De nieure nominale ,stam”.}

Allereerst onderschatte men niet de moeilijkheden waarvoor de taal zich in een dergelijk geval gesteld ziet. Het verplichte gebruik van individualiserende persoonstekens bij een aantal ,inalienabile” begrippen is zéér diep in de denk- en taalstijl der oostelijke indonesische (en melanesische) volkeren geworteld. En het moet zeker niet gemakkelijk zijn een dergelijke gewoonte te breken of te wijzigen. De kwestie is, dat men zich hier de verwantschapsverhoudingen, de geledingen van het menselijke lichaam etc., eenvoudig niet in een algemene zin kan denken. De taalvorm blijft steeds weer aan het strikt-concrete niveau gebonden. Men dient b.v. steeds ,iemands broer” te zijn, zo redeneert men hier; een arm, been etc. is steeds ,iemands arm of been" enz. En deze iemand behoort daarom ook in de taal steeds concreet en direct met een suffix achter de inalienabile woordvorm te worden aangegeven. De nominale „stam”, zo zou men het taalkundig kunnen formuleren, is in dergelijke talen meer dan ooit een wetenschappelijke en mentale abstractie; in het practisch taalgebruik blijkt daarvan absoluut niets ${ }^{66}$ ). $\mathrm{Bij}$ de alienabile groep staat het er in dit laatste opzicht natuurlijk wel enigszins beter voor. Ook hier dient wel steeds een persoonsteken te worden toegevoegd in de possessieve constructie, maar dit staat dan los van de woordvorm, n.l. achter het „possessive”, waarover we hierboven reeds herhaaldelijk hebben gesproken. Hoe vaak komen dergelijke woorden daarenboven voor buiten elke pronominale constructie d.w.z. in een geheel onpersoonlijke gedaante!

Zo luidt het b.v. in het jamdena wel wari-in; wari-m; wari-n; wari-d, wari-m; wari-b; wari-r, resp. „mijn (jouw, zijn, onze, jullie, hun) broer", maar naar een algemene niet geïndividualiseerde vorm, zoals b.v. *wari ,broer, een broer, iemands broer”, zal men tevergeefs zoeken (35). Iets dergelijks bestaat hier niet.

66) Pierre Naert, Réflexions sur le caractère du mot dans les langues anciennes et dans les langues modernes, Acta Linguistica II (1940-41), 185-191; A. Meillet, Le caractère concret du mot, Linguistique historique et linguistique générale, Paris 1936, II, 9 vv.; H. Delacroix, Le langage et la pensée, Paris 1930, $212-6 ;$ K. Bühler, Sprachtheorie, Jena 1934, 290-303; 216 vv. 
Om dezelfde reden kan men b.v. ook een zin als Onder broers klaagt men elkaar niet aan, of een andere dergelijke algemene sententie, in talen als het fordata en het jamdena niet rechtstreeks vertalen, zo deelt P. Drabbe mee. Men dient alweer de constructie eerst aldus te wijzigen, dat uitdrukkelijk uit een toegevoegd antecedent blijkt, wiens broers precies worden bedoeld. Men kan zeggen b.v. in het fordata tomat'isaa wol nmiengadu aän ta wari-n, ,niemand (lett. geen mens) klaagt zijn broers aan", of ook in de eerste persoon meervoud inclusief $i t^{\prime}$ wol tmengadu ä̈d rari-d ,wij klagen onze broers niet aan”. Zelfs een derde persoonsconstructie, d.w.z. de meest algemene en onpersoonlijke vorm die er in het gehele persoonssysteem te vinden valt, zou voor dit geval nog te concreet zijn. Een zin als aän wari-n wol rsimengadu ira zou b.v. betekenen ,zijn broers klagen elkaar niet aan” ${ }^{{ }^{77}}$ ).

Ook Adriani heeft bij zijn practisch taalonderzoek van deze streken ernstig te kampen gehad met dit gemis aan vaste inalienabile ,woordstammen”. „De woorden worden dikwijls met pronominale suffixen opgegeven”, zo klaagt hij, ,en als men de taal niet kent, bemerkt men dit vaak niet. Men vraagt b.v. naar de woorden voor ,hoofd, aangezicht, oog'....., en ontvangt (in het Boelisch) ten antwoord bokokor, oehngor, mtar.... d.i. ,ons (incl.) hoofd, oog, oor....' enz., voluit ite bokokor enz.”. Bij de werkwoorden is het al niet anders. „Naar een werkwoord vragende, krijgt men het nu eens opgegeven in den len pers. mvd. incl., zooals (sawaisch) telwau ,ademen', tenboi ,liggen',.... voluit ite telwa-u (wij allen ademen).... Andere ww. krijgt men weder in den 1sten pers. enkv. opgegeven, b.v. saw. tjip ,ik baad', st. sip-. Een andere keer wordt de derde pers. enkv. opgegeven, b.v. ntjoes , hij zuigt'.... of de $3 \mathrm{e}$ pers. mvd., b.v. roetne ,zij vragen'...." ${ }^{68}$ ).

Men kan uit deze analyse wel reeds ongeveer afleiden, welke veranderingen het indringen van de genitief op de besproken punten moet gaan brengen. De nieuwe casuskategorie weet niets van al de totnutoe geldende distincties en restricties. Het enige wat hier telt, is de verhouding van ,bezitter" tot ,bezit”; en persoon en zaak, alienabel en inalienabel, staan daarbij volkomen op één en dezelfde lijn. Een vaste suffixloze woordstam is het eerste, waarvan men nu dus uitgaat. Van de beide geopponeerde groepen, staat die der alienabilia reeds het dichtst

67) P. Drabbe, Spraakkunst der jamdeensche taai, 25.

68) N. Adriani- A. C. Kruyt, De Bare'e-sprekende Toradja's van MiddenCelebes III, 342. 
bij de te bereiken eindtoestand. We hebben dit reeds gezien. Volgens de „wet van de minste weerstand", die in al dergelijke gevallen werkt, vindt de nieuwe ontwikkeling dus ook bij deze groep weer juist het meest geschikte punt om zich aan vast te hechten. De alienabilia krijgen daarmede méér dan ooit een tijdlang het overwicht in het taalsysteem. De inalienabilia, waaronder ook een zeer groot aantal persoonsnamen schuilt, komen op het tweede plan. Verzet tegen de nieuwe stijl is op de duur uiteraard niet mogelijk, en zo worden tenslotte toch ook de inalienabilia daardoor meegesleept. Het beginsel van een vaste nominale „stam” wordt in het gehele taalstelsel systematisch doorgevoerd.

De verandering die daarmede in het taalsysteem plaats grijpt, lijkt weinig spectaculair. En enkel van buiten gezien, is ze dat zeker ook. Maar toch gaat het hier o.i. in werkelijkheid over één van de meest gewichtige punten, waardoor de melanesische (en oer-austronesische) taalstijl van de indonesische verschilt. Het taalsysteem heeft nu in beginsel een geheel andere, veel wijdere oriëntatie verkregen. De gebondenheid aan het strikt-individuele feit, dat in de melanesische talen elke, werkelijk uniforme wet onmogelijk maakt, is gebroken. En pas nu kan de nominale kategorie zich dus ook vrij en onbelemmerd ontplooien. Zeker zouden vele van de ontwikkelingen, die we hierboven reeds hebben gezien, niet mogelijk zijn geweest, of althans zich niet zo gemakkelijk overal hebben kunnen doorzetten, als daarvoor op de beschreven wijze niet een algemene en uniforme basis was gelegd waarop zij konden steunen.

Hoe de constitutie van de onpersoonlijke, inalienabile „stam"-vorm zich in de verschillende talen heeft voltrokken, is reeds door Prof. Jonker uitvoerig beschreven in zijn artikel Over de eindmedeklinkers in het rottineesch en timoreesch (BTLV 7e volgr., dl. 5, 1906, 263343). We kunnen daarnaar dus verwijzen. De moeilijkheid is alleen, naar het ons voorkomt, dat de Leidse hoogleraar niet tevens de oorzaak der door hem overigens uitnemend beschreven feiten heeft gezien. De reden daarvan is, dat in zijn tijd de oostelijke leden van de AmbonTimorgroep, de talen dus waarin de oeroude nominale tweedeling het best bewaard is gebleven, nog slechts vrij oppervlakkig bekend waren. Had Jonker het timorees en het rottinees b.v. voortdurend met het kei, jamdena etc. kunnen vergelijken, zoals dit thans mogelijk is, dan zou zijn bewijsvoering wel anders zijn uitgevallen. Alleen in dit opzicht is $n u$ dus een zekere aanvulling nodig. 
De meest gemakkelijke manier om het inalienabile woord te depersonaliseren bestaat uiteraard hierin, dat men de persoonssuffixen ineens totaal doet verdwijnen. De gewenste uniforme „stam” komt dan vanzelf zuiver voor de dag. Er zijn inderdaad gevallen, waarin de ontwikkeling, althans ten dele, op deze uiterst radicale wijze schijnt te zijn verlopen. Voorbeelden daarvan vindt men b.v. in het slaroe, merkwaardigerwijze dus juist in de taal die op andere punten het meest conservatief aan de oud-melanesische (austronesische) stijl is blijven vasthouden (35). Vooral bij de verwantschapsnamen is het determinerende teken in het slaroe opvallend vaak weggevallen. Het individu moet zich hier dus al enigszins geëvolueerd hebben van het clanverband, waarin het oorspronkelijk geheel was opgenomen. Anders was een dergelijke ontwikkeling wel niet mogelijk geweest. Bij de delen van het lichaam is van enige verandering in dit opzicht echter nog niet veel te merken. Zo luidt het hier b.v. reeds ama ,vader”, ena ,moeder”, maar nog ana-n ,kind” (met veralgemeend derde persoonsteken); kati „hart” maar klela-n „hart (van planten of bomen)”; koeskwa-n „rib” enz.

Ook in bepaalde vaste uitdrukkingen, samenstellingen en dgl. valt het persoonsteken natuurlijk eerder weg dan bij gewone woorden. Zelfs maakt men van dit middel soms gebruik om twee verwante betekenissen van elkander te differentiëren. Zo luidt b.v. fordata rela-n „(iemands) hals" maar kakeat rela ,band om den hals"; muri-n ,de achterzijde van iets" maar ntä̈-muri ,achterom zien"; azara-n ,de schouder (van iemand)" maar $n$-vara ,op den schouder dragen”; roa-n ,de afstand (van iets)" maar raroa ,ver"; vai-n „(iemands) stem” maar vai „taal”; lima-n „(iemands) hand” maar lima ,vijf” enz.

In andere gevallen is de totale vervluchtiging der persoonstekens echter niet doorgezet kunnen worden. Men kan dit ook zeer goed begrijpen. Dit middel is wel zéér kras; met de bestaande uitdrukkingsgewoonten wordt op deze wijze ineens totaal gebroken. Vandaar dat men in verschillende talen ook een zekere tussenweg bewandeld heeft, en bij bepaalde groepen van woorden eenvoudig één der bestaande vormen, die daarvoor het meest in aanmerking kwam, heeft veralgemeend. Gewoonlijk is de keuze daarbij op de derde persoonsvorm gevallen, die zoals reeds vaker is vermeld, inderdaad ook de meest algemene is van het gehele stelsel (39, 42 vv., 52 vv.). Maar ook de vormen van de eerste persoon enkelvoud of van de eerste persoon meervoud inclusief, zijn hier en daar secundair wel tot „stam"- 
vorm verheven. Dit zijn dus juist de personen, die hierboven in het citaat van Dr. Adriani al waren genoemd, en waarop ook P. Drabbe had gewezen $(53 \mathrm{v}$.). Vaak ook is de keuze bij verschillende typen van woorden niet op dezelfde wijze uitgevallen, of lopen de verschillende talen in dit opzicht sterk uiteen. Het gevolg is dan, dat de stamauslaut der inalienabilia in dezelfde taal, of anders bij de comparatie van de ene taal met de andere willekeurig schijnt te „wisselen”. Dit laatste is vooral de vorm waarin Prof. Jonker, en van zijn standpunt zeker terecht, de feiten heeft voorgesteld. Met name de auslaute $-k$, $-t$ en $-n$, zo verklaart hij, kunnen in de Ambon-Timortalen zeer gemakkelijk in elkanders plaats treden, zonder dat de oorzaak van de overgang duidelijk wordt.

Zo eindigen b.v. in het rottinees de namen van lichaamsdelen en de verwantschapsnamen bijna alle op $-k$, maar in een grote reeks andere talen treedt hier even regelmatig speciaal bij de verwantschapsnamen de auslaut $-\boldsymbol{n}$ of $\dot{n}$ op (sikka, kisser, seran-dialecten als die van Seleman, Wahinama, makian enz.). Rotti lima-k, timor nima-f $(<$ nima-w $<$ nima-u < nima-ku), maar sikka lima- $\dot{n}(<$ lima-n), en kupang zonder auslaut ima ,hand, vijf” enz. Rotti ama-k, timor ama-f, maar tettum $a m a-n$, kisser ama of ama-n; letti, moa ama, ame ; kupang ama ,vader" enz. Rotto madoi-lifu- $k$,geld bij duizenden hebbende" maar lif $u-n$ „duizend" enz.

$\mathrm{Nu}$ is het zeker geen toeval, dat juist de tekens $-k$, $-t$ en $-n$ hier „,wisselen”. Men heeft hier wel niets anders voor zich, dan de resten van juist die oer-austronesische persoonssuffixen, die zoëven reeds als de meest algemene en ,onpersoonlijke" zijn voorgesteld. Men heeft $k<1$ sg. ${ }^{*} k u ; t<1$ pl. incl. ${ }^{*} t a ; n<3$ sg. (ook wel pl.) *na. De reden van de schijnbaar regelloze ,verspringing” is dus wel duidelijk. In het rottinees is enkel, toen later de algemene nominale „stam"-vorm werd ingevoerd, de eerste persoon singularis van de inalienabile reeks secundair tot norm verheven, maar in de andere genoemde talen werd daarvoor de derde persoon gekozen. Het ene oordeel is het andere waard. Een algemeen begrip als ,een vader” kan men zich evengoed uit ,mijn vader” als uit „,iemands (zijn) vader” ontwikkeld denken.

Voorbeelden van een veralgemening van de eerste persoon pluralis inclusief vindt men in het keiees. Ook de derde persoon singularis treedt hier soms in onpersoonlijke functie op. Voor „kind, een kind” 
heeft men b.v. zowel jana-t $(<$ jana-d), oorspronkelijk „ons kind” (1 pl. incl.) als ook jana-n, oorspronkelijk ,zijn kind”. Mooi is hier ook het voorbeeld van de stam *doea ,heer, meester”. In de derde persoon singularis (doea- $n$ ) betekent de versteende vorm eenvoudig „eigenaar, heer van iets”, maar doea-d (1 pl. incl.) betekent „God, het Opperwezen, ons aller meester". Ook de eerste persoon enkelvoud doea- $\dot{n}$ komt hier trouwens soms in algemene betekenis voor. Doean tan ,eigenaar of beheerder der dorpsgronden”. Doead! Doead ruk i! „,bij God” (bezwering). Doean, doean் oh! „och God, oh mijn God!” (uitroep van schrik of ontzetting). Doean-te ,godin, de maan als godheid in sommige gebeden" ( $t e$ versterkingspartikel). Andere dergelijke voorbeelden vindt men nog passim in het reeds geciteerde artikel van Prof. Jonker.

\section{b. De pronominale vormen.}

We hebben ons totnutoe tot de nominale vormen beperkt, omdat daarop bij de inalienabile constructies de aandacht uiteraard het eerste valt. Het is echter karakteristiek voor de diepgang, die het hierboven beschreven vervormingsproces in het taalsysteem der Ambon-Timortalen heeft verkregen, dat ook de pronomina daarvan duidelijk de weerslag hebben ondervonden. Ook hier is het bestaande stelsel tot in zijn grondvesten geschokt. Het meest markante feit is, dat de distincties tussen de vormen voor de verschillende personen zich hier op de duur niet meer met de oude kracht hebben kunnen handhaven. Aan allerlei kanten zijn overgangen en vervormingen ontstaan. En juist dezelfde personen, als we reeds herhaaldelijk hebben gezien, treden daarbij het meest op de voorgrond. De samenhang tussen de nominale helft en de pronominale helft der ontwikkeling is dus ook op dit punt zeer duidelijk.

$Z_{o}$ is b.v. in het rottinees secundair de $-n$ van de derde persoon (sg. en pl.) ook ingedrongen in de eerste persoon meervoud inclusief. De $t$ - vorm, die daar oorspronkelijk thuis hoort, is thans tot enkele speciale gevallen beperkt. Welke semantische factoren deze overgang hebben mogelijk gemaakt, is wel duidelijk. Zowel de vormen van de derde persoon als die van de eerste persoon meervoud kregen bij het verval der nominale tweedeling een zekere algemene betekenis. Niet alleen uit een vorm als ama-n ,zijn (hun) vader" groeide langzamerhand de algemene nuance ,iemands vader, een vader"; hetzelfde had ook plaats bij ama-t „onze vader (incl.)", dat ,een vader, zoals wij mensen er 
allen een hebben" ging betekenen. En in deze min of meer onpersoonlijke trek hebben de beide aanvankelijk tegengestelde kategorieën elkander ontmoet. De oorspronkelijke $t$ - vorm werd vrijwel geheel door het $n$-suffix verdrongen. Juist hetzelfde als in het rottinees heeft plaats gehad, vindt men ook in het koepang $(-n)$. Ook de eerste persoon pluralis inclusief $-r$ van het boeli valt onmogelijk van $-r i$ uit de derde persoon pluralis te scheiden. In het singulare is het persoonsteken hier in de derde persoon verdwenen. In het lettinees is zelfs ook de eerste persoon meervoud exclusief bij het verschuivingsproces betrokken. Men vindt hier $-n e$ in niet minder dan vier functies (3 sg. pl. en 1 pl. incl. excl.).

In een taal als het timorees is daarentegen blijkbaar de expansie van de eerste persoon singularis uitgegaan. In de inalienabile orde is dit ook zeker een persoon van zéér bijzondere betekenis. Men vindt de $k$-vorm thans niet alleen in $1 \mathrm{sg}$, waar deze oorspronkelijk thuishoort $(<* k u)$, maar ook in de eerste persoon meervoud inclusief en de derde persoon meervoud. In de derde persoon enkelvoud is de oude $-n$ echter nog bewaard gebleven.

De diepste oorzaak van het verval der oude inalienabile suffixrij is en blijft natuurlijk het verdwijnen van de nominale tweedeling zelf. Aan het begrip ,inalienabel” ontviel daarmede elke reële grondslag. Maar het is duidelijk, dat toch ook een morphologische verwarring als die welke we zo juist beschreven hebben, op de duur funest daarop moest werken. Dat in talen als het kisser, solor enz. practisch het gehele inalienahile vormenstelsel verdwenen is, wordt op deze wijze duidelijker dan ooit.

\section{c. De meervoudsvorming.}

Behalve het noemen van de persoon deden de oude inalienabile tekens echter ook nog iets anders in het taalstelsel: zij gaven tegelijkertijd ook het numerus van het nomen aan. En nu de nieuwe casus de oorspronkelijke suffixen langzaam maar zeker begint te verdringen, vervalt dus ook deze tweede, secundaire functie. Het is daarom voorzeker geen toeval, dat men in de indonesische talen de numerusdistinctie hoe langer hoe scherper naar voren ziet komen, naarmate men meer naar het Westen komt en de oude nominale tweedeling dus vollediger is verloren gegaan. De samenhang is begrijpelijk: de taal voorziet op deze wijze eenvoudig in het gevormde functionele vacuum. Een numerus- 
aanduiding kan, althans in bepaalde gevallen, moeilijk worden gemist. Men zou nu misschien hebben verwacht, dat één der oude inalienabile elementen zèlf zich op dit moment der taalgeschiedenis tot pluralisator had ontwikkeld. Men weet, hoe vreemd in het taalleven het lot kan zijn van functieloos geworden tekens. Iedere nieuwe kategorie, die naar een uitdrukkingsvorm zoekt, kan zich daarvan a.h.w. meester maken. Karakteristiek voor de houding der taal is nu echter, dat in de archipel niets van die aard heeft plaats gehad. Niet de possessief-inalienabile elementen hebben zich hier tot pluralisator ontwikkeld, maar de personalia, zoals $\mathrm{H}$. Geeroms in een interessante studie heeft laten zien ${ }^{69}$ ). Meervoudstekens als fordata $-r$; jamdena -ar; makian $-s i$; buru -ro; slaroe $-r e$ enz., stammen alle van het personale, de kategorie waarvoor op de duur geen enkel onderdeel van het pronominale systeem veilig is (40-45). Het zijn oorspronkelijk niets dan vormen van de derde persoon pluralis. Wel heeft natuurlijk de inalienabile rij aan de andere kant de weerslag gevoeld van de ontwikkeling, die plaats greep bij het nauw verwante personale. Ook hier is daarom soms secundair de derde persoon meervoud als algemeen pluralisteken gaan functioneren. Men vindt dit b.v. in het galoli bij het teken $-r$; zie Haaksma's Inleiding 137. In het jamdena en het fordata is hetzelfde ontwikkelingsproces halverwege blijven staan. De - $r$-vorm heeft hier alleen bij de tweede persoon meervoud weten in te dringen (-mi-r, resp. $-b i-r$ naast $-b)$, maar heeft voor de eerste persoon halt gehouden. Men zie de tabel hierboven, pag, 10, 38.

\section{HOOFDSTUK VI.}

\section{De ontwikkeling van de genitief in de westelijke talen.}

We hebben hierboven de geschiedenis van het possessieve tekenstelsel beschreven, en zijn daarbij, eenvoudig de stand der feiten volgend, in eerste instantie vooral van de Ambon-Timorgroep uitgegaan. Welke aanblik vertoont dit systeem nu echter in de meer westelijk

69) H. Geeroms, Over de derde persoon meervoud in het austronesisch; BTLV 102 (1943), 41-79; voor parallellen uit andere, niet indonesische talen zie men ook J. Wils, De nominale klassificatie in de afrikaansche negertalen, op. cit. 81-87, 96-98, 276-279, 362. 
gelegen talen? Welke veranderingen zijn hier verder nog ingetreden?

Het antwoord op deze laatste vraag kan zeer kort zijn. Er zijn verder weinig of géén veranderingen meer ingetreden in de westelijke talen. De genitiefkategorie, zoals we die in het Oosten langzamerhand hebben zien ontstaan, heeft zich later blijkbaar ook in dezelfde vorm verder naar het Westen verspreid. Het nominale stamprincipe is in alle westelijke talen van het begin af aan zonder onderscheid volkomen doorgevoerd. Alleen in zoverre is hier enig verschil, dat de pronominale tekens in het Westen regelmatig uitsluitend achter de woordstam staan, dat wil dus zeggen op de plaats der vroegere inalienabile aanduiding. Een nominale tweedeling bestaat hier echter niet meer; de oude tekens zijn in algemeen-possessieve zin gereinterpreteerd.

Toch zijn uiteraard ook in het Westen hier en daar nog wel enkele lichte ontwikkelingssymptomen achter gebleven, die duidelijk naar het Oosten terugwijzen. In het bare'e en het mori komt b.v. een aantal woorden voor, waarbij het possessief suffix van de derde persoon singularis volkomen vast met de nominale woordstam is vergroeid. Mori opoe-a-no ,steel”, letterl. ,plaats van afplukking (mo'opoe) ervan”; $a n a^{2}$-no ,,jong, jong dier”. Dr. Esser omschrijft deze kategorie als die van ,namen van onderdeelen van een geheel, in 't algemeen van zaken die onmiddellijk doen denken aan iets anders waarbij zij behoren" ${ }^{70}$ ). Dr. Adriani spreekt op dezelfde wijze over ,deelen van een geheel, zoodat men vanzelf weet dat $-n j a$ [het bare'e equivalent van mori $-n o$ ] in plaats is gekomen van den naam van dat geheel" ${ }^{71}$ ). Zou in deze typische vormingen, zo is men geneigd zich af te vragen, niet een reminiscentie gelegen zijn aan de oeroude inalienabile kategorie, die we hierboven reeds zo vaak gezien hebben, en waarbij eveneens een vast persoonssuffix het typische kenmerk van de woordvorm uitmaakte? Ook in het Oosten bleven dergelijke tekens bij de latere ontwikkeling extra lang bewaard in een aantal bijzondere sprekende gevallen, zoals b.v. die der verwantschapsnamen (56).

Ook in een aantal adverbiale partikels van zeer wisselend karakter is het possessief suffix op deze wijze vastgegroeid. Bare'e $b a-n j a$,geenszins” (uit iba-nja ,het tegendeel ervan”); sawa-nja ,in plaats van te....”; pago-nja ,te meer nog” (pago ,toeijlen op”); jakoe „ik” maar

70) S. J. Esser, Klank- en vormleer van het morisch, VBG 67 (1927), derde stuk, 101 .

71) N. Adriani, Spraakkunst der bare'e-taal, VBG 70 (1931), 344. 
jakoe-nja „wat mij betreft”; kami „ons” (excl.) maar kami-nja ,wat ons betreft"; koi maar ook koi-nja ,,toe dan”. Men ziet, hoe ook in deze gevallen het verbindingsgevoel met een ander onmisbaar deel uit de zinsstructuur bijzonder sterk is.

Ook andere feiten wijzen er nog op, dat het possessieve suffix van de derde persoon enkelvoud in de westelijke indonesische talen niet onmiddellijk b.v. met het nederlandse zijn vergeleken kan worden. De uitgedrukte relatie is veel meer algemeen, meer inalienabel of ,natuurlijk" zou men bijna zeggen. De grammatici hebben dit reeds lang opgemerkt. Zo heeft men b.v. in het nieuw-javaans gevallen als ing désa iki ora ana soemoer-e, ,in dit dorp is geen put (ervoor)". Een put is volkomen onmisbaar in het dorp, en vandaar dat de gedachte hier zonder meer van het ene begrip naar het andere kan overgaan. Ing alas ikoe ana matjan-e, ,in dat bos is een tijger ervan (die er hoort)". Men vgl. ook zinnen als bare'e bara re'cpa kina'a-koe, is er nog rijst voor mij ?" se'i inaoe-moe „hier is toespijs voor je”. Voor analoge feiten in het soendanees en het madoerees zie men H. J. Oosting, Soendasche grammatica 122 vv.; S. Coolsma, Soendaneesche spraakkunst 193 vv.; H. N. Kiliaan, Madoereesche spraakkunst 81 .

Bijzonder sprekend is speciaal het zeer ongedifferentieerde karakter van de nieuw gevormde genitief in het nias. Men kan hier deze kategorie het best als een algemene status constructus omschrijven, juist zoals men die ook uit andere talen kent waar de syntactische orde zich pas begint te ontwikkelen ${ }^{72}$ ). In de genitief staat in het nias eenvoudig elk nomen of pronomen dat in een duidelijk gevoelde syntactische relatie met een ander zinslid staat. Het krijgt dan wat Sundermann de „veränderte Form” noemt, d.w.z. die met een typische anlautsvariatie ${ }^{\mathbf{7 3}}$ ). $\mathrm{Er}$ is daarbij slechts één voorwaarde: de relatie dient min of meer statisch van aard te zijn. Anders vindt men toch weer de „reine Form” zonder anlautsvariatie. Wijst ook een dergelijke constellatie niet althans op typologische samenhang met de primitieve vorm van genitief, zoals we die hierboven in de oostelijke talen zich hebben zien ontwikkelen? Zo luidt het b.v. omo n-amam-gu ,das-Haus meinesVaters (ama)"; ube'e cho n-ama-gu, ,ich-gebe (es) an meinem-Vater"; ukaoni n-ama-gu, ich-rufe meinen-Vater". In nominale constructies

72) Zie hierachter $93 \mathrm{vv}$.

73) H. Sundermann, Niassische Sprachlehre, 's Hage 1913, 16-18, et passim. 
balatu ndru' $u$ „das Messer des Grases” = das Messer zum Grasschneiden; fanofu n-ina ,die Frage der Mutter" (subjectief) maar fanof $u$ ina , die Frage (nach) der Mutter". In verbale constructies manga n-ina ,die Mutter isst"; salaw̃a n-ama ",der Vater ist ein Adeliger"; maar ama mofanõ ,,der Vater geht weg” (dus zonder anlautsvariatie en met vooropgeplaatst subject), omdat de nadruk hier op het subject ama „Vater" valt.

In de oostelijke indonesische talen kan het personale, naar we gezien hebben, optreden ter versterking of ook ter vervanging van het corresponderende possessief (16). Ook dit typisch gebruik, dat historisch gezien uit de vervalperiode der oude ,possessie"-klassen stamt, keert in de westelijke talen weer terug. En zoals het taalsysteem het hier vraagt, staat het personale dan steeds achter de nominale stam. Maleis anak sajalah (naast anakkoelah) moerid itoe ,die leerling is mijn kind”; Bima ake-d'u kamâla nahu ra-mpanga-na lako ake "dit is mijn bezoaarsteen (met nadruk; nahu ,ik") welken deze hond gestolen heeft"; maar zonder nadruk gewoon met het possessief suffix b.v. ana- $k$,mijn kind”. In het atjehs staat het personale achterop in het geval van een zekere dynamische nuance, bij een meer statische betrekking daarentegen het possessief suffix. Boeët kah (en niet boeët-kö) ,,je werk”; pönöget gobnjan (en niet pönöget-gö) „zijn maaksel”; roemoh-koe „mijn huis”; peng-kö ,je geld”.

\section{Samenvatting.}

Voorzover ons doel dat vroeg, en voorzover het de nominale zijde van de ontwikkeling betrof, hebben we hierboven enkele punten uit de indonesische taalgeschiedenis nader belicht. Men kan de resultaten a.v. samenvatten.

$1^{\circ}$ De oer-austronesische verdeling in twee nominale ,possessieklassen" is, met name in de westelijke indonesische talen, in een „gewoon" genitivisch casusstelsel overgegaan. De oude inalienabile tekens van het type $1 k u ; 2 m u ; 3 n a$ zijn daarbij secundair als casusindex gereinterpreteerd.

$2^{\circ}$ De oer-austronesische taalstijl kende geen vaste nominale „stam”, omdat in het practische taalgebruik bij de inalienabilia steeds een 
individualiserend persoonsteken diende te worden toegevoegd. De westelijke indonesische talen kennen dit uniforme stamprincipe echter wel. Het taalsysteem kreeg daarmee een veel wijder strekking. En ook voor latere ontwikkelingen werd op deze wijze een algemene basis gelegd.

We zijn hierboven uitgegaan van een zekere ,knoop” in het pronominale stelsel der indonesische talen, waarop de aandacht bij het onderzoek totnutoe nog niet voldoende gevallen was (14). Als geheel doet het tweede deel van onze studie zeker de kansen stijgen, dat de nominale streng in de „knoop” als het oudste deel moet worden beschouwd. Uitvoerig hebben we, morphologisch zowel als semantisch, kunnen nagaan hoe de oude inalienabile elementen zich tot regelrechte genitieftekens hebben kunnen ontwikkelen. Een zeer sterk punt in het betoog is het ook, dat we daarbij steeds het taalsysteem als geheel hebben zien reageren. Tussen de vele, en soms zeer ingewikkelde partiële ontwikkelingen bestond voortdurend en duidelijk een zekere samenhang. Een definitieve beslissing in ons vraagstuk kunnen we op dit moment echter nog niet nemen. Vóór het zover komen kan, dienen ook de verbale persoonsaanduidingen in bijzonderheden te worden onderzocht. Kan men zich deze laatste vormen eveneens uit de inalienabile tekens ontstaan denken? Is de verbale conjugatie waarlijk secundair in de indonesische taalgeschiedenis? En valt er ook hier verband te constateren met de oude nominale indeling in twee „possessie”-klassen? Ziedaar de vragen die wij ons, in het nu volgend deel van ons onderzoek, zullen moeten stellen, en waarvoor wij nu dus de verbale zijde van de indonesische taalgeschiedenis speciaal zullen moeten nagaan. 


\title{
DERDE DEEL.
}

\section{HET VRAAGSTUK DER FLECTIETYPEN IN HET ALGEMEEN.}

\author{
HOOFDSTUK VII.
}

\section{De geschiedenis van het debat over de flectietypen.}

Om het inzicht en de aanvoeling te scholen, geven we hieronder allereerst een korte schets van de opvattingen, die men totnutoe in de taalwetenschap gehad heeft over het feit der flectie in het algemeen, en de verschillende typen daarvan in het bijzonder. Naar volledigheid is daarbij niet gestreefd, en ook het commentaar blijft tot het striktnoodzakelijke beperkt.

De negentiende eeuw dacht typisch atomistisch, en de complexe dingen golden haar daarom steeds als „,samengesteld” en ,,secundair” t.o.v. wat zij als ongesplitst en eenvoudig beschouwde. Zo is ook een geflecteerde verbale vorm hier steeds als een zekere synthese opgevat, semantisch evenzeer als morphologisch. Audio gold op de een of andere wijze als volkomen gelijkwaardig met ego + audire; percutimus was geheel aequivalent met nos + percutere enz. Ja, zozeer zat deze gedachte de taalgeleerden zelfs in het bloed, dat hun waardering voor een taaltype steeg naarmate de verbinding der elementen in de synthetische verbale vorm inniger en meer volkomen was.

Als de modus, binnen welke zich de veronderstelde secundaire verbinding voltrok, golden verder gewoonlijk de verhoudingen van het abstracte praedicerende ,oordeel”. Hier verraadt zich een tweede typisch negentiende eeuwse trek: het overdreven logicisme, en wel in het bijzonder in die vorm die het engelse sensisme en het duitse idealisme daaraan hadden gegeven. Zo gold als het beste voorbeeld van 
een werkelijke „flectie” en een werkelijk „,subject” bij de meeste auteurs het z.g. praedicatieve werkwoord. Tussen stamvorm en persoonsindex kon hier slechts met moeite nog de grens worden teruggevonden. Juist aan de andere kant van de scala stond dan het ongeconjugeerde of „vormeloze” werkwoord. (De negatieve benaming is karakteristiek). Grammaticale termen als „,subject” en „praedicaat” konden hier in de grond slechts per analogiam worden gebruikt. De beide delen der constructie staan in de grond volkomen los en zonder enige verandering naast elkaar: ego audire; nos percutere. En tussen deze beide extremen in was er tenslotte nog plaats voor de overgangsvorm der agglutinatie, waarbij het subjectsteken en de stam slechts vrij los met elkander in verbinding werden gebracht. In zeer veel gevallen was het subjectsteken hier possessief van oorsprong, en men sprak dus ook wel van ,possessieve" flectie.

Men ziet, hoe in een dergelijke gedachtengang alle toenmaals bekende feiten ineens konden worden overzien. Zelfs voor de rangschikking en de waardering van de practisch voorkomende conjugatietypen had men op deze wijze onmiddellijk alle gewenste houvast. Voor de propaganda en de bestendiging der theorie lag er in zulk een strakke opzet zeker een grote kracht.

\section{A. De periode van het "praedicatieve" en het „possessieve" werkwoord.}

Het begrip van het „praedicatieve” werkwoord vindt men reeds bij niemand minder dan W. von Humboldt, blijkbaar onder invloed van de contemporaine duitse idealistische philosophie ${ }^{74}$ ). Grammaticale begrippen als „subject” en „praedicaat” worden door de geniale geleerde regelrecht in philosophische zin gereinterpreteerd. Voor Von Humboldt is het werkwoord „der Nerv der ganzen Sprache”. Alleen deze „Gattung” is z.i. in de zin "der Leben enthaltende und Leben verbreitende Mittelpunkt"; alle overige leden zijn slechts ,gleichsam todt daliegender, zu verbindender Stoff". De oorzaak van deze unieke positie ligt hierin, dat uitsluitend aan het werkwoord ,der Act des synthetischen Setzens als grammatische Funktion beigegeben (ist)". Elke geflecteerde verbale

74) W. von Humboldt, Ueber die Verschiedenheit des menschlichen Sprachbaues, und ihren Einflusz auf die geistige Entwickelung des Menschengeschlechts. Berlin 1836 (= Gesammelte Werke Bd. VI, 1-425).

Verh. dl. XII. 
vorm heeft daarom praedicerende functie, en drukt in de grond een existentieel en praedicerend oordeel uit. Laudo is b.v. niets anders dan een eenvoudige manier om te zeggen ego sum laudans; equus currit $=$ equus est currens enz. „Durch einen und ebendenselben synthetischen Act knüpft (das Verbum) durch das Sein das Prädicat mit dem Subjecte zusammen, allein so, dasz das Sein, welches met einem energischen Prädicate in ein Handeln übergeht, dem Subjecte selbst beigelegt, also das blosz als verknüpfbar Gedachte zum Zustande oder Vorgange in der Wirklichkeit wird.... Der Gedanke, wenn man sich so sinnlich ausdrücken könnte, verläszt durch das Verbum seine innere Wohnstätte und tritt in die Wirklichkeit über".

Zozeer behoort zelfs de praedicerende kracht volgens W. von Humboldt tot het verbale wezen, dat hij deze ook nog tracht terug te vinden waar de uiterlijke vorm daartoe geen of geen voldoende basis meer biedt, nl. bij het possessieve en het vormeloze werkwoord. Ook daar dient men z.i. bij de analyse steeds de copula toegevoegd te denken. De possessieve flectie met name berust op een dubbele „Verdunkelung” (268). Gewoonlijk maken de talen onderscheid tussen possessiva en personalia; de eerste horen speciaal bij het nomen thuis, de laatste bij het verbum. „Wo dies aber nicht der Fall ist, verbindet sich der Begriff der Person schwankend und unbestimmt mit dem einen und mit dem anderen Redetheil. Der Unterschied beider Fälle wird wohl empfunden, aber nicht mit der formalen Schärfe und Bestimmtheit, welche der Uebergang in die Lautbezeichnung erfordert." (279). Ook de grenzen tussen nomen en verbum zijn in de talen met possessieve flectie enigszins vloeiend. „Dasselbe Wort kann als beide Redetheile gebraucht werden....”. „(Die) Verbindung des Pronomens ist so lose, dasz man gezwungen wird, zwischen demselben und dem.... Verbum.... das Verbum sein im Geiste zu ergänzen" (266).

Waren de geest en de taal voor W. von Humboldt nog in een soort hypostatische unie verenigd geweest, bij figuren als Bopp en Schleicher daalt de vlucht der gedachten aanmerkelijk. Met name Schleicher neemt een kras materialistisch standpunt in, en ontkent met nadruk dat er in de taal ,inneres Leben" kan zijn, ,,das nicht in die erscheinung tritt”. Wie anders leert, zo verklaart hij kortweg en beslist, stelt de gehele methodologie der taalwetenschap op losse schroeven.... Zo worden natuurlijk de concrete taalvormen voor hem zowel het begin als het eindpunt van alle studie. Ieder taalkundig kenmerk is van morpho- 
logische aard. Voor het werkwoord heeft de taal b.v. de persoonstekens gereserveerd, voor het nomen daarentegen uitsluitend de casussuffixen. Het resultaat is, dat Schleicher alleen aan het indogermaans de erepalm toekent van een echt werkwoord met een echt type subject te bezitten. Dit werkwoord is "praedicatief" van natuur, in de zin van W. von Humboldt. Een „possessieve” verbale vorm is echter niets dan een nomen ${ }^{75}$ ).

De leer over het „praedicatieve" werkwoord bereikt haar hoogtepunt bij Fr. Müller, die tevens de naam voor het type voorstelt. Alleen bij de praedicatieve flectie ontstaat volgens Fr. Müller ,ein förmliches Urteil”, een gesloten syntactische constructie, een echte zin met een echt werkwoord. Alleen hier identificeert het grammaticale subject zich ten volle met de agens der handeling. Uiterlijk kan men dit hieruit aflezen, dat nu de subjects-index bij het werkwoord direct van het corresponderende personale is afgeleid. Skr. tud-a-mi "schlagend-ich" = ich schlage; $t u d-a-t i$,schlagend-er” $=$ er schlägt. Bij het possessieve flectietype daarentegen zijn „Stoff” en „Form” der taal nog slechts onvolledig van elkander gescheiden. Het grammaticale subject geldt nu ook enkel als zijdelings bij de behandeling betrokken (,nur äuszere Beziehung”). En het werkwoord blijft hier daarom in de grond niets anders dan een nomen. Het subjectsteken valt samen met de possessieve index; de syntactische constructie is géén gesloten eenheid. Kanuari (ni) wri-nem „,dein Sehen”, cfr. soba-nem „dein Freund”; (ši) wu-tse „sein Sehen”, cfr. soba-n-tse „sein Freund" "76).

De analyse gaat bij Von Humboldt, Fr. Müller e.a. niet uit, naar men ziet, van de concrete taalervaring, d.w.z. van de enige basis waarop de taalwetenschap redelijkerwijze kan worden opgebouwd, maar van een analyse a posteriori van de meegedeelde gedachteninhoud. In laatste instantie is de beschouwing dus extra-linguistisch van karakter. Er ligt natuurlijk een zeker denken in de taal; de aangeduide realiteit wordt ook objectief bereikt. Niemand zal dit ontkennen. Maar dit „taaldenken” is van een heel ander karakter dan het denken dat de formele logica pleegt te onderzoeken. Een woordbetekenis is allerminst een logisch begrip, zoals dit na een zeker proces van abstractie uit de werkelijkheid gewonnen kan worden. Voor de ervaring is de betekenis onmiddellijk

75) A. Schleicher, Die Unterscheidung von Nomen und Verbum in der lautlichen Form. Abh. der Kön. Sächs. Ges. d. Wiss. Bd. X (1865), 497-587, 505.

76) Fr. Müller, Grundrisz der Sprachwissenschaft I, 1, 107 v., 123, 125 vv. 
met de aangeduide werkelijkheid één. $Z_{\mathrm{ij}}$ maakt daarvan eenvoudig deel uit. En termen als „subject” en ,praedicaat” worden dus in de philosophie en in de taalkunde telkens in een geheel andere, en niet onmiddellijk te vergelijken zin gebruikt.

Ziet men de zaken zo, dan valt het niet te verwonderen dat er reeds in de negentiende eeuw zèlf verzet gerezen is tegen de eenzijdig logisch gerichte opvattingen van Von Humboldt, Fr. Müller enz. Met name Steinthal, de leider der opkomende psychologische school, heeft zich tot de tolk daarvan gemaakt. Een zin als equus currit, zo zet hij uiteen, drukt geen logisch oordeel uit, maar enkel een zekere constatering; zij doet een simpele mededeling. Meer niet. De erepalm onder de flectietypen gaat bij Steinthal aldus ook goeddeels over naar het agglutinerende type. „Was liegt daran”, zo luidt zijn motivering, ,ob die Verbindung der grammatischen Sylben mit den Wurzeln loser oder enger ist?" „Die Flexion ist nichts als eine verschobene und verkrüppelte Agglutination... Die Sache aber ist die, dasz unsere Sprachforscher meist sosehr in der Untersuchung von Formen stecken bleiben, dasz sie die Form nicht sehen ${ }^{77}$ ). Men ziet, dit is in ieder geval taal die aan duidelijkheid niets te wensen over laat.

\section{B. De periode van het „passieve” werkwoord.}

Rond de wending van de eeuw komt er een min of meer principiële verandering in het vraagstuk der flectietypen, en wel tengevolge van de ontdekking van het z.g. ,passieve" werkwoord door Schuchardt en C. C. Uhlenbeck, resp. in de kaukasische talen en in het baskisch en een aantal noord-amerikaanse talen ${ }^{78}$ ). De nieuwe feiten werken allereerst als een frontverbreding. Had men zich totnutoe bij de analyse der

$\left.{ }^{77}\right)$ H. Steinthal, Charakteristik der hauptsächlichsten Typen des Sprachbaus, Berlin 1860, 12.

78) H. Schuchardt, Ueber den passiven Charakter des Transitivs in den kaukasischen Sprachen, SBAWW, Bd. 133 (1895), I, 1-91; -, Ueber den aktivischen und passivischen Charakter des Transitivs, IF 18 (1905), 528-31. C. C. Uhlenbeck, Karakteristiek der baskische grammatica, VAWA, vierde reeks, achtste deel, eerste stuk (1906), $4-42$; - , Het passieve karakter van het verbum transitivum of van het verbum actionis in talen van Noord-Amerika, VAWA, vijfde reeks, tweede deel, tweede stuk (1906), 187-216; Pedro de Yrizar, Sobre el caracter pasivo del verbo transitivo, o del verbo de accion, en el vascuence y en algunas lenguas del norte de America, Publicaciones de la Real Sociedad Vascongada de Amigos del Pais, San Sebastian 1950. 
verschillende flectietypen beperkt tot de vergelijking der subjects- en der praedicaatskategorieën, thans blijkt dat ook aan het object in dit verband een plaats toekomt. Het subject en het object vormen met het werkwoord een trits, waarvan men de eenheid niet zonder schade kan ontkennen of beknotten. Zo komt b.v. in het kaukasische awar een objectsconjugatie voor, die geheel op één lijn kan worden gesteld met wat elders de gewone subjectsconjugatie is. Het werkwoord congrueert eenvoudig met het „logische” object zoals dit elders met het „logische” subject geschiedt. Dica razi ha-v-àla emèn ,door-mij tevreden maaktzich-daar ( $h a$ „,maken”; $v$ als teken voor de mannelijke klasse) vader” $=$ ik stel mijn vader tevreden; maar dicà razi ha-i-ìla ebèl „,door-mij tevreden maakt-zich-daar ( $i$ voor de vrouwelijke klasse) moeder " $=\mathrm{ik}$ stel mijn moeder tevreden.

Wat de subjectsaanduiding betreft, volgens de „passieve” opvatting staat deze bij de transitiva niet in de nominatief of in de genitief, maar in de instrumentalis of de ablatief. Er kan hier dus nòch van een „praedicatieve” nòch van een ,possessieve” opvatting sprake zijn. Men zie de reeds gegeven voorbeelden. Bij de intransitiva en ook bij de praedicatieve verhouding vindt men daarentegen een nominativische constructie; awar: d'un v-it'una" ik ga (mannelijk subject)", maar d'un i-it'una ,,id. (vrouwelijk subject)"; (d'un ,ik" (nom.); dir ,van mij” (gen.)).

Bij de pronominale subjectsindices kan aldus in het „passieve” milieu zelfs soms een tweedeling in de vormen ontstaan. Er is een ,actief" of ,energetisch” type, maar daarnaast ook een ,,inert” type dat bij de intransitiva als subjectsindex fungeert, maar daarnaast tevens ook bij de transitiva als objectsteken. Aldus b.v. baskisch $d$-a-kar-t ,ihn (verbindingsvocaal) tragen durch-mich" = ich trage ihn; cfr. h-a-kar-t ,ich trage dich (masc.)”; $d$-a-bil ,er geht”. Op dezelfde wijze ook $n$-a-bil ,,ich gehe”, maar evenzeer $n$-a-kar-su ,mich tragen durch-dich” $=$ du trägst mich.

$\mathrm{Na}$ de ontdekking van het „passieve” werkwoord kon men de kwestie der flectietypen vollediger overzien dan ooit. Toch is de tegenstelling tussen de verschillende standpunten in eerste instantie aldus eerder verscherpt dan verzacht. Schuchardt en C. C. Uhlenbeck hebben het „passieve” type met evenveel kracht verdedigd, als Trombetti, Finck e.a. het bestaan en de betekenis daarvan hebben ontkend. Welke diepe wortels deze tegenstelling had, zal nog nader blijken. Een tweede trek 
uit de nieuwe phase van het debat is, dat het centrum van de strijd zich nu vooral ook verplaatst naar het historisch aspect. Het gaat er voortaan niet meer zozeer om, hoe de verschillende flectietypen worden opgevat, als wel om de vraag hoe men zich deze in één grote gesloten ontwikkeling geordend kan denken. Ieder der partijen kiest voor zijn scala weer een ander punt van uitgang. En zo leven de oude tegenstellingen enkel in een nieuwe vorm voort.

Het dichtst bij de oude opvatting blijven staan figuren als Wundt, en vooral F. N. Finck. De taal is voor hen allereerst een É oyov en geen $\dot{\varepsilon} v \varepsilon \varepsilon^{\prime} \gamma_{\varepsilon} \iota \alpha$ - Schuchardt zal, niet bij toeval, later het omgekeerde betogen, naar men weet -; het nomen is primair t.o.v. het verbum. En zo komen zij ertoe ook aan het possessieve flectietype, dat het meest nominaal aandoet, het historische prius toe te kennen in vergelijking met alle andere. Men zou hier dus van een zeker ,possessivisme” kunnen spreken.

Bijzonder scherp heeft Wundt de possessieve en de praedicatieve flectietypen tegenover elkander gekarakteriseerd. Deze zijn elk voor hem exponenten van een geheel andere taal- en denkstructuur. De possessieve flectie reflecteert het natuurlijke en primitieve „nominale” of "gegenständliche Denken”. Handelingen en eigenschappen der dingen worden daarbij als ,einen Besitz” opgevat. De praedicatieve flectie daarentegen berust op een veel meer gecompliceerde en gerationaliseerde stijl, die van het bewegelijk-verbale „zuständliche Denken”. In plaats van de gedachte aan een zeker bezit, geldt hier de meer algemene van een „Gebundenheit wechslender Zustände und Vorgänge an einen sie tragenden Gegenstand". De denkvorm voltrekt deze laatste overgang vanuit het ik. ,So wird mit innerer Notwendigkeit das an den Gegenstand sich anlehnende Besitzpronomen durch das persönliche Pronomen ersetzt" ${ }^{\text {79}}$ ).

Men ziet welke krachtige wapenen Wundt de possessivisten in de hand drukt met een dergelijke beschouwing. Niet alleen behoeven zij voortaan niet meer de concurrentie van het "praedicatieve" werkwoord te vrezen, zij kunnen daartegenover voor het possessieve flectietype nu zelfs met recht en reden op het historische prius aanspraak maken. Duidelijk ziet Wundt ook, welk een geweldige verandering het opkomen van een verder ontwikkeld werkwoordstype betekent voor de gehele

79) W. Wundt, Die Sprache ${ }^{4}$ II, $140-143 ; 169$ v. Men zie ook W. Schmidt, W. Wundt's Völkerpsychologie, MAGW 33 (1903), 377-81. 
taal- en denkstructuur. Zonder overdrijving kan hij spreken van ,eine der gröszten Revolutionen, welche die Geschichte des menschlichen Denkens überhaupt aufzuweisen hat".

Wat voor Wundt nog enkel een theoretisch uitgestippelde ontwikkelingsmogelijkheid was, zet de radicale en pragmatische figuur van $\mathrm{F}$. N. Finck onmiddellijk om in een practisch evolutieschema ${ }^{80}$ ). Zijn meest persoonlijke bijdrage tot het probleem is daarbij vooral een interessante distinctie tussen de „Tatverben” en de „Empfindungsverben”. „Tatverben" zijn werkwoorden waarbij de agens uitdrukkelijk gevoeld wordt als het centrum der verbale dynamiek, die verder centrifugaal verloopt. Naargelang de nuance meer passief of actief gericht is, hebben ze een ablativisch of een nominativisch subject (a rege interficitur servus; rex interficit servum). De Empfindungsverba daarentegen zijn de werkwoorden van gevoelsreacties en zintuigelijke waarnemingen. Het subject wordt $\mathrm{nu}$ min of meer door de van buiten stammende dynamiek "getroffen", en staat daarom in de datief (mihi videtur; mir ertönt es). Het gehele schema, dat natuurlijk van de possessieve flectietypen uitgaat, ziet er a.v. uit :

$\begin{array}{cc}\text { Possessief type: des Vaters-Sehn } & \text { des Vaters-Erscheinung } \\ \text { durch den Vater-das Sehn } & \text { dem Vater-das Erscheinen } \\ \text { durch den Vater wird gesehen } & \text { dem Vater erscheint } \\ \text { Tatverben (passief type: } \text { Zuid- } & \text { Empfindungsverben } \\ \text { kaukasische talen) } & \text { (eskimo, georgisch) }\end{array}$

Naar de lezer opmerkt, ontbreekt in deze tabel de zuiver actieve variant van het ,Tatverb” (nieuw-grieks). Finck geeft ronduit toe, dat hij geen kans ziet dit verbale type in verbinding te brengen met de possessivistische stijl waarvan hij is uitgegaan. Hij volgt in dit opzicht dus niet Wundt, die speciaal deze laatste karakteristieke verbindingslijn had uitgewerkt. Tenslotte neemt Finck aan, dat het zuiver actieve werk-

s0) F. N. Finck, Der angeblich aktive Charakter des transitiven Verbs; KZ 41 (1907), 209-282; 266; -, Die Haupttypen des Sprachbaus ${ }^{2}$, Leipzig 1923; -, Die Grundbedeutung des grönländischen Subjektivs, SPAW 1905, 280-7. Zie ook E. Lewy, Possessivisch und passivisch, Ungarische Jahrbücher 8 (1928). 
woord zich volkomen zelfstandig en „ohne eine lang herrschende Übergangsform" heeft ontwikkeld uit het primitieve vormeloze werkwoord, dat ook in de oertijd reeds hier en daar naast de possessieve flectie voorkwam (chinees). De handeling wordt bij dit type niet voorgesteld als het bezit van de agens, nòch als ,etwas ihm irgendwie Zukommendes oder ihm Gleichzustellendes”, maar als ,,sein ganz eigenes, persönliches Werk" ${ }^{81}$ ). Het onderscheid met het possessieve type is er dus ook hier weer een van graad.

Schuchardt, even breed in zijn comparatie als zijn voorgangers maar een veel dieper en critischer natuur, staat uiteraard geheel anders dan Wundt of Finck. Het is echter niet gemakkelijk aan zijn opvattingen volkomen recht te laten wedervaren. Het probleem van het ,passieve” werkwoord is het probleem van Schuchardt's leven geweest, zo kan men zonder overdrijving zeggen. Telkens en telkens weer is hij daarop teruggekomen, en pas langzamerhand is zijn gedachtengang geheel uitgekristalliseerd en helder geworden. De eerste phase van Schuchardt's ontwikkeling is reeds uitvoerig beschreven door Prof. Royen in zijn boek over de nominale klassificatie. Van onze kant zouden wij daarom vooral op het laatste deel daarvan de nadruk willen leggen, dat wel het meest karakteristieke en het meest persoonlijke is. Bedriegen nl. niet alle tekenen, dan is Schuchardt geëindigd met even exclusief passivist te zijn als vooral Finck possessivist was. Zijn serie Sprachursprung $1-3$, de laatste groep van samenhangende verhandelingen die de grote geleerde heeft geschreven, betekent, naar het ons wil voorkomen, niets anders dan een grootse poging om langs theoretische weg eens en voorgoed de oorspronkelijkheid van het ,passieve” type aan te tonen. De verbale flectie kan zich volgens Schuchardt nergens anders hebben ontwikkeld dan daar. Dat anderzijds zulk een mentale volte-face ook enorme offers vroeg, zal niemand betwijfelen. En in dit geval waren ze zeker niet gering. Schuchardt's ideeën over de subjects- en de objectscategorieën, dat wil practisch dus zeggen de punten waarin de verschillende flectietypen het sterkst van elkander afwijken, blijven in de serie Sprachursprung helaas vrij vaag. En het is de vraag, of de onvermijdelijke aandacht voor het detail daarbij wel op alle punten met het fascinerend perspectief van de grote lijn gelijke tred heeft gehouden.

81) Een analoge formulering later bij E. Schwyzer, Zum persönlichen Agens beim Passiv, besonders im Griechischen; APAW 1942, nr. 10; 11 vv. 
Allereerst vergelijkt Schuchardt in zijn Sprachursprung de actieve en de passieve constructietypen. Alleen het standpunt van de spreker wisselt hier, zo verklaart hij; de beschreven loop van zaken is in beide gevallen geheel dezelfde. „In der Urzeit (und noch heute in früher Kindersprache) ist $A$ schlag- zweideutig". Pas later, in de periode der drieledige zinnen, ontstaat er differentiatie. "Schlag- spaltete sich in schlagen und geschlagen werden" ${ }^{2}$ ).

Over het verloop van dit laatste proces, en met name over de rol die het object, d.i. dus het derde lid van de drieledige zin, daarbij speelt, heeft Schuchardt zich zeer uitvoerig uitgelaten. „Wenn wir aus der Ferne die undeutliche Wahrnehmung machen, dasz einer einen andren schlägt”, zo redeneert hij, „so sagen wir: dort gibt es Schläge o.ä. Treten wir näher, so finden zwei Feststellungen statt, die, sei es auch nur durch den kleinsten Zeitraum getrennt sind, nämlich dasz A schlägt und dasz B geschlagen wird. Die beiden zweigliedrigen Sätze

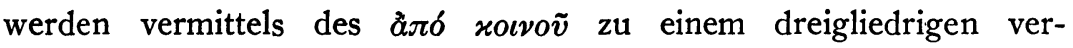
schmolzen, wobei das zweite Subject in die Rolle eines Prädikats herabgedrückt wird :

$$
\begin{array}{cccc} 
& \text { S } & P=S & P \\
\text { A } & \text { schlag-(Akt.) }=\text { schlag-(Pass.) } & & \text { B } \\
\text { A } & \text { schlägt; geschlagen wird } & \text { B }
\end{array}
$$

Es kann aber auch der welcher geschlagen wird, zuerst ins Auge fallen, dann ergibt sich

$$
\text { B wird geschlagen; schlagen tut }
$$

A

Wird anfangs die $Z$ weideutigkeit von $A$ schlag- $B$ nur fallweise durch die Umstände behoben, so geschieht dies dann grundsätzlich in den einzelnen Sprachen; d.h. in den einen bedeutet es soviel wie „A schlägt B”, in den anderen wie „A wird von B geschlagen”, und wir reden dann von ,aktivischem" und ,passivischem Transitiv".

Men ziet hoe het taalkundig objectsbegrip (in de gewone zin van het woord) in deze beschouwing vrijwel geheel zijn eigen karakter verliest. Voor de comparatie is dit natuurlijk een feit van zeer groot belang. Inderdaad legt Schuchardt op dit punt sterk en zeer welbewust

82) H. Schuchardt, Sprachursprung II, SBAW 1920, 460; zie ook H. Vogt, Un aspect du problème actif-passif dans le verbe; Journal de psychologie normale et pathologique 1950, 130-138; G. Royen, Die nominalen Klassifikations-Systeme in den Sprachen der Erde, Mödling bei Wien 1929, 818-821, 887-890, 895 v. 
de nadruk. „Die Definition des Objectes durch das Transitiv und des Transitivs durch das Object ist nichtssagend, und der Begriff des Objectes wie der des Transitivs ermangelt jeder wirklichen Stütze. Nominativ und Akkusativ sind innerlich gleich....; sie sind aber auch nicht den übrigen „Kasus” gegenüberzustellen.... (Jedes) Objekt ist ein in den Schatten gerücktes Subjekt, dass Prädikat zu einem Prädikat".

Voor het possessieve flectietype is Schuchardt's verklaring daarentegen veel eenvoudiger. Schuchardt houdt dit enkel voor een variant van het passieve type, die ontstaan is in een omgeving waar het verbum secundair tot op zekere hoogte met het nomen is samengevallen. Van de beide constructies dies Haus ist vom Kaufmann gebaut worden en dies ist das Haus vom Kaufmann is zeker de eerste de meest oorspronkelijke. „Man besitzt dasjenige was man erworben hat (,erwirb es um es zu besitzen', sagt Faust); und in der Urzeit bestand das Erwerben im Schaffen; es gab keine ,beati possidentes' ". ...,,(Es) ist nichts leichter, als (die possessivische Auffassung) durch die passivische zu ersetzen" ${ }^{83}$ ). ....,Da die Mitteilung bei der Lautsprache in linearer Weise erfolgt, so sind, wenigstens ursprünglich, die Beziehungen nur auf doppelte Weise darstellbar (A B und B A, aktivisch oder passivisch). Die sog. possessivische Darstellung der Verbs läszt sich nur als sekundäre denken, als Anpassung an Gebilde, die selbst langer Vorbereitungen bedurften" ${ }^{84}$ ).

C. C. Uhlenbeck, die het werkwoord in het baskisch en in een aantal noord-amerikaanse talen heeft bestudeerd, deelt van zijn kant in de grote lijn natuurlijk wel Schuchardt's ideeën over het ,passieve” type, maar er zijn toch ook zeer karakteristieke verschillen aan de dag getreden tussen deze beide geleerden, waarover eveneens helaas totnutoe slechts weinig in de literatuur te vinden is. Vooreerst is C. C. Uhlenbeck b.v. geen extreem passivist, in deze zin dat hij de passieve constructie overal ter wereld voor het primitieve feit zou houden en waarvan de analyse in ieder geval zou moeten uitgaan. Z.i. is het passieve werkwoord slechts ,,voor een zekere phase van geestesontwikkeling....

83) H. Schuchardt, Possessivisch und passivisch, SPAW 1921, 657.

84) H. Schuchardt, Sprachursprung I-III, SBAWB 1919, 716-20; 863-9; ibid. 1920, 448-462; - Exkurs zu Sprachursprung III, SBAWB 1921, 194207; -, Possessivisch und passivisch, SPAW 1921, 651-62; -, Das Baskische und die Sprachwissenschaft, SWAW 202 (1925), Abh. 4. 
de voor de hand liggende en natuurlijke" ${ }^{85}$ ). De gemaakte restrictie heeft zeker diepe zin: C. C. Uhlenbeck, de typische methodologische eclecticus, is niet ten offer gevallen aan het éénlijnige historisme van de tweede helft der negentiende eeuw. We komen daarop nog terug.

Een tweede verschilpunt betreft de casus energeticus, de karakteristieke subjectsnaamval dus van het „passieve” werkwoord. Schuchardt ziet daarin, naar zoëven gebleken is, in principe de gelijkwaardige van de overeenkomstige naamval bij het ,actieve" werkwoord, juist zoals hij in zijn drang om overal sporen van het „passivisme” te vinden ook het onderscheid tussen de subjects- en de objectskategorieën zoveel mogelijk heeft verkleind en teniet gedaan. C. C. Uhlenbeck daarentegen neemt tussen deze beide kategorieën duidelijk een zeker graadsverschil aan. De casus energeticus noemt z.i. slechts „het primaire instrument” en niet ,de eigenlijke agens" van de handeling. Deze laatste blijft voor het primitieve taalgevoel ,een verborgen macht”, en wordt daarom niet uitgedrukt. Voor de subjectsaanduiding van het ,actieve” werkwoord geldt ditzelfde niet, althans niet in gelijke vorm. In een zinnetje uit het Blackfoot, een taal dus met ,passieve” constructies, als „Den vogel doodt hij met een steen" wijst hij die doodt slechts op ,den schijnbaren agens". Hoewel afhankelijk van de verborgen en ongenoemde oermacht weet deze toch "door zijn emanerende orenda" invloed op het object uit te oefenen. De gewone instrumentalis ,met een steen" staat nog een trapje lager; deze wijst enkel op ,het secundaire instrument". Men zou de casus energeticus daarom ook wel de „casus emanativus” of ,de naamval van de uitstralende kracht" kunnen noemen.

Men ziet, hoe zich dus ook bij C. C. Uhlenbeck duidelijk de behoefte doet gevoelen aan een groot verband waarbinnen pas de afzonderlijke feiten op hun eigenlijke waarde kunnen worden geschat. Zijn visie is echter veel voorzichtiger, en ze blijft ook veel dichter bij de feiten dan die van Schuchardt.

In dezelfde sfeer van gedachten ligt ook C. C. Uhlenbeck's aanval op de traditionele indeling der talen in isolerende, agglutinerende en flecterende talen, waarover hierboven eveneens reeds gesproken is (65).

85) C. C. Uhlenbeck, Het passieve karakter van het verbum transitivum of van het verbum actionis in talen van Noord-Amerika, VAWA 1916, 213 vv. Cfr. ook American Anthropologist, NS 35, 353-6 (recensie van E. Sapir, Southern Paiute). Verder ook C. C. Uhlenbeck, Karakteristiek der baskische grammatica, VAWA, 1906, 4-42; - , Het identificerend karakter der possessieve flectie in talen van Noord-Amerika, VAWA 1917, 345-371. 
Met allerlei scherpzinnige argumenten, vooral aan de morphologie ontleend, bewijst de hoogleraar dat met name tussen de beide laatste typen van vaste grenzen geen sprake kan zijn. De gehele indeling zal z.i. moeten verdwijnen ${ }^{86}$ ).

\section{De reactie der, ,activisten”.}

Tot zover over het standpunt der possessivisten en der passivisten. Hoe heeft de ontdekking van het ,passieve” werkwoord nu echter gewerkt op het activistische kamp, d.w.z. op figuren van het type van W. von Humboldt, Fr. Müller enz.? Heeft men zich hier kunnen verenigen met ontwikkelingsschema's als die van Finck en Schuchardt? Hoe staat men thans in het algemeen tegenover de leer aangaande het ,passieve" werkwoord?

Men dient hier te antwoorden met een distinctie, zo schijnt het ons. Het quasi-philosophische kleed waarin het activisme was gehuld, is in ieder geval verdwenen. Dit is zeker een belangrijk winstpunt. $\mathrm{Na}$ Fr. Müller heeft géén enkel theoreticus het meer gewaagd de leer over het "praedicatieve" werkwoord als zodanig te verdedigen. Ook de traditionele driedeling der taaltypen, die daarmede nauw samenhing, leeft thans nog enkel in populair-wetenschappelijke werken voort. De kernfout van het activisme lag echter, naar uitvoerig gebleken is, in het typische logicisme, of iets breder bezien: in het typisch rationalistische wereldbeeld, waarvan men bewust of onbewust uitging. De taalwetenschap werd aldus tot een soort ancilla philosophiae. De taalfeiten werden naar de logische analyse a posteriori beoordeeld en geklassificeerd, terwijl toch redelijkerwijze enkel de concrete, personale taalervaring daarbij de basis kan zijn. Niet het eng-rationalistische maar het algemeen-phenomenologische standpunt moet beslissen.

En ziet men de zaken nu zo, dan kan men inderdaad niet anders dan constateren, dat er in de algemene grammatica, ook wat de verbale kwesties betreft, nog menig spoor van de oude, al te ,logische" opvattingen is achtergebleven. Ja, men kan zeggen, dat men op dit punt in werkelijkheid pas begint te beseffen waar precies de eigenlijke moeilijk-

86) C. C. Uhlenbeck, Aglutinación y Flexión. Congreso III de Estudios Vascos, Guernica 1922. Vgl. ook Prof. Uhlenbeck's antwoord op het Questionnaire van het Vijfde internationale linguistencongres, Brussel 1939; Réponses I, 69 v. 
heden zijn gelegen, vooral aan de hand van het sindsdien sterk toegenomen comparatieve materiaal. Hoe vaak wordt b.v. thans nog in de grammatica's enkel door een schijnbaar „objectieve” gedachtenanalyse uitgemaakt, of een bepaald werkwoord "transitief" is of niet! Of dit door een ,,direct object” vergezeld wordt of niet! „Transitief” is in vele gevallen juist zulk een lexicaal kenmerk geworden bij het werkwoord als b.v. de nominale klasse dit is bij het substantief. Voorbeelden hiervan zullen later nog volgen. Op dezelfde wijze ontstaat, zuiver op grond van een logische, d.i. extra-linguistische deductie, vaak ook de mening, dat het genus activum en het genus passivum verbi volkomen omkeerbare constructietypen voorstellen. Het subject en het object bij een verbale constructie worden als kategorieën van geheel dezelfde rang cn structuur beschouwd, juist zoals wij dit zoëven ook bij Schuchardt vonden. Dat de werkelijke verhoudingen hier echter geheel anders zijn, is bij een voorgaande publicatie reeds gebleken ${ }^{87}$ ).

Onder de comparatisten die zich, ook thans nog min of meer consequent en bewust, op het activistische standpunt stellen, dient allereerst Trombetti te worden genoemd ${ }^{88}$ ). Trombetti kan de possessivisten en de passivisten op géén enkel punt tegemoet komen. $\mathrm{Hij}$ is even puur activist als b.v. Finck possessivist en Schuchardt passivist was. Hier ligt zeker de diepste reden voor de felle botsing die tussen deze drie grote geleerden, en verder met Prof. C. C. Uhlenbeck heeft plaats gevonden, en waarbij o.i. elk zich voor zijn deel op de feiten kon beroepen ${ }^{88}$ ). Typisch empiricus als Trombetti is, heeft hij weliswaar nooit met even zoveel woorden deze algemene trek uit zijn taalbeschouwing geformuleerd. Ieder die zijn werken leest en herleest, zal daarom echter niet minder van het gewicht en de betekenis daarvan doordrongen zijn.

87) J. Wils, De oorsprong van het verbale $r$-passief in de indogermaansche talen, VAWA 3, 11 (1940), 7 (443); E. Wistrand, Uber das Passivum; Göteborgs Kungl. Vetenskaps och Vitterhets-samhälles Handlingar, Sjätte Följden, ser. A, Band I, no. 1 (1941).

88) A. Trombetti, L'unità d'origine del Linguaggio, Bologna 1905, 128-130; -, Elementi di glottologia, Bologna 1923, 264-271; 279-289; 748; - , Le origini della lingua basca, Bologna 1925, 160 vv.

89) Het aandeel dat Prof. Uhlenbeck heeft gehad in dit debat is, met nog verschillende andere details, reeds uitnemend beschreven door Prof. Royen, Die nominalen Klassifikations-Systeme in den Sprachen der Erde, Mödling bei Wien 1929, 864-939. 
Tegen ,(il) così detto ,verbo possessivo" " voert Trombetti b.v. aan, dat het volstrekt niet vaststaat, dat de taal in haar eerste ontwikkelingsstadium reeds de genitief als bezitsaanduiding heeft gekend. Hoe zou zich hier dan wel een genitivisch flectietype hebben kunnen ontwikkelen? „Non esistendo il concetto del possesso, non poteva esistere il verbo possessivo" (Elementi 272). En wat het passieve werkwoord betreft, meent Trombetti dat een dergelijke uitdrukkingswijze, waarbij het logische subject zich niet als de werkelijke agens van de handeling beschouwt, maar enkel als het primaire instrument waardoor deze tot stand komt, redelijkerwijze alleen denkbaar is in een fatalistische en deterministische levensbeschouwing. Dat de primitieve mens zulk een visie op de dingen zou hebben gehad, lijkt hem echter uitgesloten. De oermens moet geleefd en gesproken hebben van de daad, zijn eigen, practische en concrete daad! De ergatief, de naamval van het ,primaire instrument", is z.i. daarenboven volstrekt niet een soort tweede-rangs subject, zoals C. C. Uhlenbeck gemeend had. De agens der handeling wordt hiermede integendeel juist op bijzonder krachtige en sprekende wijze aangeduid. "L'ergativo non è che una specie di nominativo enfatico" (265). In het baskisch heeft men b.v. $n i$,io", maar als ergatief de versterkte vorm $n i-k$, die men het best met ,io stesso" of iets dergelijks kan weergeven. Vgl. washo $m \bar{\imath}$,tu” maar $m i-k$,tu stesso”. Een vertaling als „da me, per opera mia” zou hier veel te zwak wezen. $\mathrm{Ja}$, er zijn volgens Trombetti zelfs gevallen, zoals b.v. in de kaukasische talen, waarin de ergatief als de basis van het gehele casussysteem optreedt. Alle andere casusvormen worden nu daarvan afgeleid. Dan is met het voorgaande zelfs nog niet genoeg gezegd. In zulke talen stelt de ergatief blijkbaar niets anders voor dan de woordstam zelf in zijn actieve betekenis. „L'ergativo non è un caso, ma un tema” (265).

Onder de vertegenwoordigers der algemene taalwetenschap, die „,activist” zijn, kan men verder nog speciaal op Meillet wijzen, merkwaardigerwijze terzelfdertijd één van de meest competente bestrijders van de traditionele driedeling der taaltypen waarover hierboven gesproken is. In een critiek op één der werken van Schuchardt verklaart Meillet b.v. eenvoudig „Le verbe est essentiellement actif”. Nadere motivering of commentaar wordt daarbij verder niet gegeven. De passieve opvatting is hiermee ineens van de baan ${ }^{90}$ ).

90) MSL 18, 273. 


\section{De opvattingen in de indonesische grammatica.}

Keren we na dit algemeen theoretisch-historisch uitstapje weer naar het speciale indonesische terrein terug. Waartoe heeft het verkregen overzicht ons nu geleid? Dat de moeilijkheden aldus zijn opgelost, zal men zeker niet kunnen zeggen. De vorm waarin deze zich aandienen moge wellicht gewijzigd zijn, de klemmende pointe is zonder twijfel gebleven. Toch is onze gang door de negentiende eeuw niet onvruchtbaar geweest, zo wil het ons voorkomen. De indonesische vragen hebben een meer algemene achtergrond gekregen en de verhouding tussen de verschillende meningen wordt daardoor scherper belicht. Eén punt is in ieder geval onmiddellijk duidelijk. De opvattingen die we hierboven als de ,,activistische" hebben leren kennen, hebben blijkbaar ook op het indonesische terrein diep, zeer diep doorgewerkt. Niemand zal daarover na het voorgaande ook wel verwonderd zijn.

Vooreerst immers is het in de indonesische grammatica's vrijwel algemeen de gewoonte de subjectstekens van het vervoegde werkwoord zonder meer met het corresponderende pronomen personale te identificeren. Men heeft b.v. een maleis paradigma als $k u$-pukul (ook $a k u$ pukul) ,ik sla”; kau-pukul (ook énkau pukul) ,jij slaat”; kami pukul „wij slaan”; kamu pukul ,jullie slaan” enz. In het meervoud treden de personalia hier dus duidelijk op als subjectsindex. Welnu, zo redeneert men, blijkbaar is in het enkelvoud juist hetzelfde het geval. Een vorm als $1 \mathrm{sg}$. $k u$ - staat in de grond geheel gelijk met $a k u ; 2$ sg. $k a u-$ met énkau enz. Het geringe optredende vormverschil is alleen een kwestie van accent. $A k u$; énkau zijn de oorspronkelijke lento-vormen; $k u-; k a u-$ zijn daarnaast enkel ontstaan als allegro-vormen in de samenstelling met de verbale stam. Of zoals men het gewoonlijk formuleert, $k u$; $k a u$ - zijn uit $a k u$; enkau ,verkort” of ,afgeleid”. Dat niet alle grammatici zich daarbij ten volle bewust zijn van de diepere achtergrond, waarop hun redenering berust, kan men geredelijk aannemen. De traditionele theorie, waarvan de zakelijke onjuistheid hierboven reeds gebleken is, maar waarvan eerst thans de meer principiële grondslag duidelijk aan de dag treedt, 'wordt daarom echter niet minder regelmatig door het ene boek van het andere overgenomen (vgl. 6vv.).

Verder verwerpen ook practisch alle indonesische vakgeleerden eenstemmig, en zonder nadere motivering, de leer over het possessieve werkwoord. Alleen Dr. S. J. Esser neemt in dit opzicht een enigszins 
ander standpunt in ${ }^{91}$ ). Evidente possessieve flectietypen als b.v. die van het minangkabau, bimanees, sa'danees, fordata etc. worden met een half oog aangezien, en enkel als afwijkingen van de normale verhoudingen geboekt. „Passieve” constructies als die van het sangirees, tontemboan enz. worden zelfs in het geheel niet als conjugatievormen beschouwd, blijkbaar alleen omdat de agensaanduiding hier possessief van origine is en achter de stam staat (tontemboan sisile $\dot{n}-k u$, het wordt

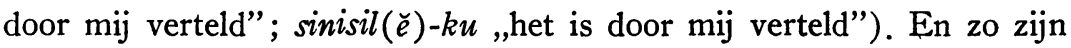
er nog allerlei andere feiten van dezelfde aard meer.

Bij het „passieve” werkwoord beginnen de moeilijkheden echter eerst recht, juist dus als in de algemene taalwetenschap. De ,activisten” (nu in de zin der indonesische grammatica genomen) verwerpen ook dit constructietype, zoals onder de comparatisten b.v. ook Trombetti dit doet. De „passivisten” daarentegen die in werkelijkheid eveneens halve ,activisten" (in algemene zin) zijn, naar reeds gebleken is, willen daarvoor, juist als Prof. C. C. Uhlenbeck, wel een zekere kleinere of grotere speelruimte openlaten. De verdeling van de argumenten tijdens het debat is hierbij altijd zeer merkwaardig geweest. De „passivisten” hebben zich voornamelijk op hun globale aanvoeling beroepen, die door jarenlange practische en wetenschappelijke omgang met de betreffende talen inderdaad bijzonder geschoold was; de „activisten” van hun kant hebben daarentegen steeds meer de concrete feiten voor zich gehad. Een practisch, comparatief-stilistisch onderzoek als b.v. dat van de Sajárah Mĕláyu door Tendeloo ${ }^{82}$ ), of een reconstructie van de oerindonesische vormen der conjugatietekens door Prof. Jonker ${ }^{93}$ ), is van de zijde der ,passivisten" nooit geleverd. Zo is de tegenstelling der meningen hier zeker langer bewaard gebleven en scherper geworden, dan anders wel nodig geweest was.

Alles hangt er nu natuurlijk verder maar vanaf, wat men bij het indonesische debat precies onder het "passieve” werkwoord verstaat. Er heerst daaromtrent nog vrij veel onzekerheid. „Passivisten” als de Hollander, Klinkert, Gerth van Wijk e.a. gebruiken regelmatig aan-

91) S. J. Esser, Nogmaals de vervoegde vormen, Feestbundel van het Kon. Bataviaasch genootschap van Kunsten en Wetenschappen, deel I (1929), 161 vv.

92) H. Tendeloo, Feiten en cijfers uit de Sajárah Mĕláyu in verband met enkele betwiste hoofdpunten der Maleische Grammatica, TITLV 60. Zie ook M. G. Emeis, Vorm en functie in klassiek en modern maleisch, Utrecht 1945.

93) J. Jonker, Over „vervoegde” werkwoordsvormen in de Maleisch-Polynesische talen, BTLV 65 (1911), 266 vv. 
duidingen als „subjectief passief” of ,grammaticaal passief”. Bijzonder gelukkig is een dergelijke terminologie zeker niet. Men krijgt, zoals gezegd, de indruk dat de grammatici aldus eerder hun globale aanvoeling der feiten onder woorden hebben willen brengen, dan wel een consequente en systematische theorie geven. Iets dergelijks als dit laatste bestaat er aan "passivistische" zijde helaas niet.

Aan de andere kant zijn echter ook de ,activisten" niet altijd geheel zakelijk en verantwoord geweest in hun houding. En met name is van hun kant de term "passief" in de combinatie "passief werkwoord” vaak verstaan alsof het ging over een kategorie in een westerse taal als b.v. het latijn (video: videor; laudo: laudor etc.); dat wil dus zeggen als het volslagen tegendeel van ,actief”. Zulk een simplistische opvatting heeft $\mathrm{nu}$ echter in genen dele in de bedoeling gelegen van figuren als Schuchardt en C. C. Uhlenbeck, die het "passieve” type hebben ontdekt. Men zal in hun werken tevergeefs zoeken naar uitdrukkingen die in een dergelijke richting wijzen. Dat er bij zulk een verschil van beoordeling zeker ook veel onnodig misverstand is gerezen bij het debat over het indonesisch werkwoord, spreekt vanzelf. En een van onze eerste opgaven zal dus moeten zijn te trachten op dit beslissende punt zoveel mogelijk heldere begrippen te verkrijgen.

Tot zover het historisch overzicht. Een concrete en directe conclusie is daaraan niet verbonden. Dit was ook niet te verwachten. In zoverre is er toch echter wel resultaat, dat de analyse van het indonesische werkwoord, en daarmede ook de vraag naar de herkomst van de verbale subjectstekens die we hierboven hebben gesteld ( 9 vv.; $14 \mathrm{vv}$.), ook bij bredere belichting een anmerkelijk meer ingewikkelde opgave blijkt te zijn dan gewoonlijk wordt aangenomen. De keuze gaat blijkbaar niet enkel - ziedaar wel het voornaamste punt - tussen de ,activistische" en de ,passieve” opvattingen. Ook de „possessivisten” hebben stem in het kapittel. En zoals ons bij de reconstructie hierboven al gebleken is, is deze stem reeds zeeér oud. $\mathrm{Zij}$ is niets minder dan die van de oertaal zelve. 


\section{HOOFDSTUK VIII.}

\section{Structurele benadering van het vraagstuk.}

De taalwetenschap van onze dagen is geen ,andere" taalwetenschap dan die uit de negentiende eeuw en het begin van de twintigste eeuw. En hier b.v. van een „principiële” methodologische breuk te spreken, zoals wel geschiedt, is zeker overdreven. Toch valt het moeilijk te ontkennen dat er in de laatste tientallen van jaren, met name onder invloed van de structuurgedachte, wel veel in de taalkundige opvattingen is verschoven of althans bezig is te verschuiven. En de vraag is nu maar voor ons doel, of daarbij ook punten aan de dag zijn getreden, die het mogelijk maken dieper in het verbale flectieprobleem in te dringen. Het vastgelopen debat dient weer op gang, en zo mogelijk tot een goed einde te worden gebracht.

In ieder geval kan men naar onze indruk, in eerste instantie, een tweetal methodologische eisen formuleren waaraan een geheel aangepaste analyse naar de nieuwere inzichten zou hebben te voldoen.

Daar is dan allereerst het gewichtige feit dat de taal naar de structurele beschouwing vóór alles als een orde sui generis beschouwd dient te worden. Men staat hier voor een geheel eigen klasse van de gedragsgewoonten, een geheel eigen intentionaliteit, en - begrijpelijkerwijze dus ook voor een geheel eigen systeem van uitdrukkingsmiddelen. Ieder weet hoe zich in deze laatste formulering de "semiologische” taalopvatting uitspreekt, zoals F. de Saussure die in zijn Cours heeft gegeven, en die later vooral door de phonologische school is uitgewerkt. Daarnaast mag echter niet over het hoofd worden gezien, dat het hier volstrekt niet een conclusie betreft, die alleen van taalkundige zijde getrokken is. Verscheidene beoefenaars van zusterwetenschappen die eveneens met taalfeiten te maken krijgen, zijn - langs hùn weg tot juist dezelfde gedachtengang gekomen. Men kan b.v. wijzen op philosophen als Scheler, Heidegger, Lavelle, Jaspers, Delanglade, Schmalenbach, Parain; op psychologen als Pradines en vooral MerleauPonty; en in de psychiatrische hoek op leiders van het aphasieonderzoek als Gelb, Goldstein, Feuchtwanger, Isserlin, Von Kuenburg e.a. Men handelt daarom wel niet onvoorzichtig met zich op de eerste plaats aan dit karakteristieke gegeven te houden.

Voor ons doel zit er aan dit theoretische gezichtspunt onmiddellijk 
ook een gewichtige practische conclusie vast. Vormt de taal allereerst een eigen orde, dan zal ook het onderzoek naar de kategorieën daarvan zich op de eerste plaats weer binnen deze geheel eigen sfeer moeten bewegen en voltrekken. Het te verrichten onderzoek naar de verbale flectievormen zal m.a.w. een zuiver linguistisch karakter moeten dragen. Men zou een dergelijke gedragslijn als vanzelfsprekend kunnen beschouwen, zodat het nauwelijks nodig is deze apart te formuleren. Maar aan de andere kant is het taalfeit, zoals zich dit in het practische leven voordoet, een uiterst complex phenomeen. In allerlei verband vertoont de taal een zekere bemiddelende functie. En niets is daarom ook eenvoudiger dan vanuit de orde van de taal andere, naburige gebieden te bereiken, juist zoals het omgekeerd ook niet de minste moeite oplevert om vanuit andere terreinen tot het strikt-taalkundige te komen. Hoe moeilijk in dergelijke omstandigheden de analyse kan worden, behoeft geen betoog. Men kan menen een taalkundig spoor te volgen, en in werkelijkheid op een totaal ander kompas zeilen. De gevolgen zijn dan natuurlijk funest. In dezelfde mate als het centrale taalfeit niet geheel zuiver wordt geconcipiëerd, valt ook op de afgeleide en toegepaste kategorieën een scheef licht. Men overdrijft niet met te zeggen, dat de taalkundigen gedurende de honderd en vijftig jaren dat er nu van taalkunde in de moderne zin sprake is, op de beschreven wijze in een hele reeks van gevallen zonder verdere kritiek of aanpassing eenvoudig de noties en begrippen van philosophen, sociologen, psychologen etc. hebben overgenomen, waarmee het onderzoek hen - soms vrij toevallig - in aanraking bracht. Hier ligt zeker één van de voornaamste oorzaken van de onzekerheid die de taalkunde in onze dagen op zo menig dieper punt kenmerkt.

Ook het flectiedebat, dat we zoëven hebben beschreven, valt zonder twijfel niet van al dergelijke methodologische ontsporingen vrij te pleiten. En met name is, naar het ons voorkomt, de veel-verspreide leer dat er $1^{\circ}$ in de taal slechts één type van subject kan voorkomen, en dat $2^{\circ}$ dit subject dan steeds in de z.g. ,eerste" naamval of de nominatief behoort te staan, daarvan het onmiddellijke gevolg geweest. Hoe de aanhangers van de ,praedicatieve” werkwoordsopvatting tot hun gedachtengang zijn gekomen, hebben we reeds vermeld. Van de taal hebben zij niets anders gemaakt dan het voertuig van de strikt-logisch opgevatte gedachte, en van de taalkunde daarom ook niets anders dan een soort ancilla philosophiae. Anderzijds werden „activisten” als 
Trombetti en Meillet aan het begin van de twintigste eeuw vooral door het reële en pragmatische karakter van de werkwoordelijke uitdrukking getroffen. De concrete, practische daad wordt daarmede direct en concreet bereikt. De taal was naar hun inzicht vooral een ancilla realitatis. De agens en de wereld tegenover deze golden voor hen daarenboven van het begin af aan als twee geheel gesloten en incommensurabile grootheden. Alleen door een speciale en apart geïntendeerde act kon het contact daartussen tot stand worden gebracht. Het taalkundige correlaat van dergelijke opvattingen kan men zich denken. Wordt het initiatief tot de overbrugging door de agens genomen, dan ontstaat het z.g. actieve genus verbi, in het omgekeerde geval echter het passieve genus. De agens wordt dan door de omringende wereld bereikt. In beide gevallen staat het subject, de aanduiding voor de initiatiefnemer, in de eerste naamval of de nominatief. Elke subjectsaanduiding is ,actief" van natuur.

De redenering der ,activisten” gaat op twee punten mank. Dat het taalfeit de werkelijkheid inderdaad bereikt en direct uitdrukt, is door het moderne onderzoek zonder twijfel bewezen. Tezelfdertijd is intussen ook komen vast te staan, dat ieder taalsysteem tot dit doel weer andere middelen aanwendt. Ieder volk heeft daarbij weer een eigen voorkeur. Men spreekt van een zeker ,stilistisch” beginsel. En juist aldus ontstaan overal die markante verschillen die het studieobject van de comparatist uitmaken. „Each language”, schrijft Boas kort maar krachtig, "has a peculiar tendency to select this or that aspect of the mental image which is conveyed by the expression of the thought; .... in each language only a part of the complete concept we have in mind is expressed" ${ }^{94}$ ). Ja, iedere spreker kan duidelijk weer zijn eigen wegen kiezen op een dergelijk moment; en zelfs in een en hetzelfde gesprek kan zijn stijl in bepaalde opzichten nog wisselen, indien daartoe om welke reden dan ook aanleiding bestaat. De verhouding van de taal tot de werkelijkheid is door de "activisten” m.a.w. ten onrechte in een strikt mechanische en experimentele zin opgevat. De taal is niet enkel een weergave in ,short-hand" van de phenomenologische kategorieën die de spreker bij zijn handeling doorschrijdt. $Z \mathrm{ij}$ is een middel om als

94) F. Boas, Handbook of american indian languages I (Washington 1911), Introduction 43. Vgl. ook E. Cassirer, Le langage et le monde des objets; Psychologie du langage, Paris 1933, 23 vv.; J. van Ginneken, Wat is taal? Onze taaltuin 3 (1935), 265-275. 
mens tussen de wereld en de andere mensen te leven en te verkeren, en evengoed als de objectieve werkelijkheid heeft daarbij ook de eigen subjectiviteit haar aandeel. De zaken zijn hierbij veel meer complex dan de ,activisten" wel hebben gezien.

Daarbij komt nog dat ook het wereldbeeld waarvan figuren als Trombetti en Meillet - zeker goeddeels onbewust - uitgingen in werkelijkheid veel meer variabel en bewegelijk, maar ook veel meer levensnabij en rijk was dan zij wel meenden. De menselijke persoon is géén onbewegelijke, gesloten eenheid. $\mathrm{Zij}$ is de levende pool van het ervaringsleven, die onmogelijk van de tegenpool der objectieve werkelijkheid kan worden gescheiden. De mens leeft niet in zijn ,ik”, om enkel bij het handelen, vluchtig en als bij toeval, contact te nemen met de incommensurabele stijl tegenover hem. Hij leeft in de wereld; voortdurend doorstroomt hij deze met zijn subjectiviteit, ,,incorporeert" hij bepaalde delen daarvan, zoals W. James het boudweg formuleert. En de wereld werkt weer op hem terug, en verleent hem op haar beurt vorm en gestalte. Nooit is daarenboven het verband tussen deze beide polen zo goed geordend en zo vol betekenis, als juist bij het stellen van een verbale handeling. Elke handelingservaring, zo leert de nieuwere psychologie uitdrukkelijk, wordt allereerst gedragen door de beleving van de situatie als geheel. De eigen persoon van de agens vormt daarbij gewoonlijk slechts een vrij ondergeschikt element in het grote verband, een zekere subjectieve organisatievorm van de situatie, maar méér ook niet. Alleen wanneer er aan de onderlinge aanpassing iets hapert, of wanneer het bestaande, geheel en al doorleefde verband op de een of andere wijze wordt verbroken, trekt de ene pool zich als het ware in zich zelf terug. De mens bezint zich dan op zijn ,ik”, en op hetzelfde moment wordt hij zich ook van zijn activiteit bewust als van een typisch-individueel gebeuren.

Hoe zou men dus onder dergelijke, steeds weer wisselende omstandigheden in de grammatica slechts met één en voor alle gevallen voldoende type „subject” kunnen volstaan? Hoe zou men deze kategorie redelijkerwijze alleen voor die constructies kunnen reserveren, waarin de spreker zichzelf (resp. de partner) uitdrukkelijk kenmerkt als het dynamisch-dramatische centrum van de gehele verbale activiteit? En dat nog wel op straffe, dat anders de handeling niet als een „eigenes, persönliches Werk" zou mogen gelden!

Een dergelijke eis is zeker te hoog, of eigenlijk niet met voldoende 
kennis van zaken, gesteld. Men zou op deze wijze de stijl van het uitzonderingsgeval, dat van de haperende aanpassing of de eenzijdiggeobjectiveerde ontwikkeling, stellen boven die van de normale verhoudingen, inplaats van omgekeerd. Zo wordt het natuurlijke evenwicht totaal verbroken.

Een tweede belangrijk winstpunt van het structuralisme, dat eveneens tot methodologische consequenties leidt, is verder nog gelegen in de overtuiging dat ook het grammaticale stelsel van elke taal afzonderlijk weer een gesloten en zelfstandige eenheid vormt. Voor ons doel betekent dit, dat dus het onderzoek naar de flectievormen zo breed mogelijk zal moeten worden opgevat. Natuurlijk zal men bij de studie van de verbale feiten moeten beginnen. Deze zijn echter lang niet altijd gemakkelijk te bereiken, en zo zal het in bepaalde gevallen - het gevoerde debat heeft dit ruimschoots bewezen - eveneens nodig zijn daarnaast b.v. ook het casussysteem na te gaan. Daarmee worden dus geen heterogene feiten onder één hoofd gebracht; het debat wordt niet nodeloos uitgebreid, maar juist omgekeerd wordt aldus verenigd hetgeen slechts door toevallige grammaticale of morphologische grenzen van elkander was gescheiden.

Alles bijeengenomen, is het dus wel een veelomvattend en ingewikkeld program dat zich op deze wijze voor onze ogen begint af te tekenen. Zolang de aldus gestelde eisen echter door het materiaal zelf worden gesteld en als direct daaraan zijn ontleend, behoeft men zich daarover niet ongerust te maken. En veel erger zou het zijn een eenvoudiger en minder veeleisende methode te hanteren, die echter niet geheel op de reële feiten was ingesteld.

\section{HOOFDSTUK IX.}

\section{De structuur van de subjectscategorie.}

$\mathrm{Na}$ al deze historische en methodologische beschouwingen kunnen we thans eindelijk overgaan tot het directe onderzoek in ons vraagstuk. Als eerste thema zouden we daarbij de vraag naar de aard en de structuur van de subjectskategorie aan de orde willen stellen, een van 
de voornaamste punten dus die ook vroeger reeds in het flectiedebat een beslissende rol speelden.

$\mathrm{Er}$ is misschien geen term die een grammaticus gemakkelijker uit de pen of uit de mond vloeit, dan die van ,subject”. Wat houdt deze notie nu echter precies in? En wat is, scherp en kort geformuleerd, de structuur van deze kategorie? We kennen reeds de logische en de striktpragmatische opvattingen daarvan. Daarnaast vindt men ook nog wel - in ons land b.v. bij J. van Ginneken - een vooral psychologisch georiënteerde zienswijze. Het subject wordt dan gezien als de aanduiding van het element waarbij in de geest van de spreker de gedachtenbeweging begon. Vandaar gaat deze dan verder voort naar het natuurlijke eindpunt, d.w.z. het praedicaat. Ook in dit geval gaat de analyse dus van extra-linguistische feiten en grootheden uit, de taalkundige verhoudingen worden enkel als de mechanisch gebonden correspondenten daarvan beschouwd. De taalkunde echter is een zelfstandige wetenschap, zij dient uit te gaan van haar eigen begrippen. De taal is een geheel apart vlak der menselijke gedragsgewoonten, dat volgens eigen structuurbeginselen is opgebouwd. De gegevens van andere vakken, hoe nauw verwant ook in sommige opzichten, kunnen daarbij enkel een zekere heuristische waarde hebben. Het eindresultaat zelf zal van taalkundige aard behoren te wezen, en uitsluitend van taalkundige aard.

Wat schiet er ons als werkwijze in deze omstandigheden dus over? Blijkbaar niets anders dan een zover mogelijk uitgebreide inductieve methode. We zullen zoveel mogelijk typen en soorten van subject in de verschillende talen van de wereld dienen na te gaan. We zullen zo scherp mogelijk daarvan de structuur moeten bepalen, om dan aan het slot te zien of er op deze wijze wellicht zekere algemene wetten en bouwprinciepen te achterhalen vallen. Psychologische of philosophische kategorieën blijven aldus geheel buiten de beschouwingen. In eerste instantie is het onderzoek enkel registrerend en comparatief.

Welnu, gaat men aldus te werk, houdt men op deze manier zo goed mogelijk rekening èn met de lessen van het verleden èn met de methodologische eisen van het ogenblik, dan ontwikkelt zich, naar onze indruk, een geheel ander beeld dan de vroegere theorieën wel hebben verondersteld.

Hierboven hebben we de leer over het enig mogelijke, en daarom ook overal verspreide nominativische subject reeds leren kennen als 
een scheve philosophische of psychologische reminiscentie in de taalkunde. Naast de methodologische bezwaren komen thans echter ook nog feitelijke moeilijkheden te staan. De gewone negentiende eeuwse theorie komt volstrekt niet met de concrete taalgegevens overeen. Bij het grammaticale begrip ,subject” dient men in de wereld der talen met minstens vier geheel verschillende mogelijkheden rekening te houden. Iedere taal interpreteert in beginsel deze kategorie weer anders. Er zijn talen waarbij het subject een zéér eenvoudige kategorie voorstelt, en waarbij deze slechts op een enkele betekeniscomponent berust. Er zijn echter ook veel meer gecompliceerde typen, waarbij de verschillende in aanmerking komende factoren zich a.h.w. met elkander hebben verbonden, zodat de betekenisstructuur een zeer abstract karakter heeft gekregen. Toch blijft er bij dit alles, zo wil het ons voorkomen, voldoende reden om al deze verschillende typen en vormen van subject niet van elkander te scheiden, en te trachten deze als één bijeenbehorende groep van feiten te verklaren. De aanwezigheid van reeds één enkele factor is voldoende om met alle recht en reden bij de analyse van een werkelijk subject te spreken. Bij de meer gecompliceerde typen komen vormen voor de dag die herinneren aan wat ook in de westerse talen algemeen voor representanten van de subjectskategorie wordt gehouden. Men vindt m.a.w. bij dit gewichtige grammaticale begrip weer juist dezelfde disjunctieve relevantie terug, die men ook reeds uit het semantisch en structureel onderzoek van de gewone, lexicologische woordbetekenis kent ${ }^{\text {95}}$ ).

\section{A. De dynamiek der persoonlijke handeling.}

$\mathrm{Er}$ is dan vooreerst een vrij groot aantal talen waarin de subjectskategorie duidelijk op niets anders berust dan de aanduiding van de personale dynamiek. De gebruikte subjectsaanduiding kenmerkt de handelende persoon uitdrukkelijk als het centrum van de plaats grijpende activiteit. Dit is dus duidelijk het element dat door de „activisten" zo beslissend werd geacht, dat zij daarmede ineens de

95) Toepassingen van deze methode bij J. van Ginneken, De tijden van het werkwoord. Taalkundige afdwalingen. Nijmegen 1923; 43; J. Wils, Zitten, Onze Taaltuin I (1933), 333; - Structuurtypen in de beteekenis van nederlandsche bewegingswerkwoorden; ibid. 6 (1939), 311; A. Reichling, Het Woord. Een studie omtrent de grondslag van taal en taalgebruik. Nijmegen 1935, 321-324; F. Hintze, Bemerkungen zur Methodik phonologischer Untersuchungen der Wortstruktur; Studia Linguistica 2 (1948) 137. 
kategorie als zodanig volledig meenden te hebben getekend. Hoe nauwkeurig intussen de beschreven bredere grondslag in het oog gehouden dient te worden blijkt wel hieruit, dat in de meeste van dergelijke gevallen ook een zekere distinctie aan de dag treedt. Er zijn voorbeelden in het taalgebruik waarin de dynamiek wordt gevoeld en uitgedrukt, maar daarnaast staan er ook andere waarbij dit niet het geval is, of althans niet in dezelfde praegnante vorm. Naar de structuur geoordeeld, zou men alleen bij de eerste groep van vormen in de strikte zin van een casus kunnen spreken in ongeveer dezelfde zin als dit b.v. ook in de indo-europese talen geschiedt. In het andere geval gaat de kategorialisatie echter duidelijk veel minder ver. Men staat ongeveer voor een subject in de vorm van een bepaling. Kortheidshalve zou men hier dus wellicht ook bij de beschrijving kunnen spreken van een ,subjectsbepaling".

a. Zo vindt men vooreerst een aantal talen, waarbij het subject in de meer eigenlijke zin duidelijk tot de kategorie der transitiva is beperkt. Men kan een dergelijke distinctie ook zeer wel begrijpen en verstaan. Bij de transitiva "gaat" de handeling uitdrukkelijk van het subject ,over” op een andere grootheid, het „object” zoals de grammatica het gewoonlijk omschrijft. Het ,ik" en de wereld hebben hier beide een zekere kern, misschien zelfs in beide gevallen een personale kern. Kain doodde Abel. De heer straft zijn slaaf. Hoe gemakkelijk kon dus juist in zulke omstandigheden de dynamiek van het subject aanschouwelijk worden! Hoe sprekend was in dit geval de tegenstelling tot het object, dat door de handeling werd ,getroffen"! Bij de intransitiva blijft daarentegen de handeling geheel tot de eigen persoon van het subject beperkt. De vorm der dynamiek is nu dus veel minder sprekend.

In weer andere talen komt de volop doorleefde personale dynamiek van het subject rechtstreeks tot uitdrukking, geheel onafhankelijk van het verbale hoofdtype. De distinctie is nu dus iets meer algemeen georiënteerd dan in het voorgaande geval. In de amerikanistiek is men gewoon in het eerste geval een casus transitivus tegenover een casus intransitivus te stellen, maar in het tweede een casus activus tegenover een casus inactivus ${ }^{96}$ ).

Zo vindt men de tweedeling van een casus transitivus en een casus intransitivus, natuurlijk niet steeds in geheel dezelfde vorm, en soms

96) C. C. Uhlenbeck, Het passieve karakter van het verbum transitivum of van het verbum actionis in talen van Noord-Amerika, op. cit. 213. 
ook met andere distincties vermengd, b.v. op Nieuw Guinea in papuatalen als miriam, kai, saibai ${ }^{97}$ ); in Voor-Indië in het tibetaans en een aantal daarbij aansluitende talen ${ }^{\oplus 8}$ ); in de kaukasische groep b.v. in het kabardi, ubych ${ }^{89}$ ); verder in het baskisch ${ }^{100}$ ), eskimo ${ }^{101}$ ), fins ${ }^{102}$ ); in Noord-Amerika in het tsimshian, chinook, de muskogeise talen enz. ${ }^{103}$ ). Volgens C. C. Uhlenbeck's bekende hypothese heeft, naar men weet, ook het oer-indogermaans juist deze oppositie in zijn casusstelsel gekend vóór het tot de latere tegenstelling van een nominatief en een accusatief overging ${ }^{104}$ ).

Wil men ook in de vertaling rekening houden met al dergelijke, zowel morphologisch als psychologisch diep gefundeerde distincties, dan dient b.v. een constructie als miriam neur-de nesur ikeli ongeveer

97) S. H. Ray, Reports of the Cambridge Anthropological Expedition to Torres Straits III, Cambridge 1907.

98) Jäschke-A. H. Francke, Tibetan grammar, Berlin 1929; 21 vv.; 114. Cfr. A. Trombetti, Elementi di glottologia 685 v.; G. Royen, Die nominalen Klassifikations-Systeme, op. cit. 929-933 (ook parallellen uit nog andere gebieden). Zie ook L. Hambis, Grammaire de la langue mongole écrite, I, Paris 1946, 27; J. Bacot, Grammaire du tibétain littéraire, Paris 1946, 47, 81.

99) A. Dirr, Einführung in das Studium der kaukasischen Sprachen 39 vv.; -, Die Sprache der Ubychen, Caucasica 4 (1927), 75; 85 vv.; Nils Holmer, Iberocaucasian as a linguistic type; Studia Linguistica 1 (1947), 11-44.

100) C. C. Uhlenbeck, Karakteristiek der baskische grammatica, VAWA, 1906, 21 vv.; K. Bouda, Das transitive und das intransitive Verbum des Baskischen, VAWA 1933; Pedro de Yrizar, Formacion y desarrollo del verbo auxiliar Vasco, Boletin de la Real Sociedad Vascongada de Amigos del Paris, San Sebastian 3 (1947) en 4 (1948); - , Los dialectos y variedades del Vascuence, Homenaje a don Julio de Urquyo, San Sebastian 1949, 375-424.

101) F. N. Finck, Die Grundbedeutung des gronländischen Subjektivs, SBAWB 1905, 280-7; C. C. Uhlenbeck, Ontwerp van een vergelijkende vormleer der eskimotalen, VAWA A'dam 1907 (nr. 8); W. Thalbitzer, Eskimo, in Handbook of American indian languages, Washington $1911 ; 967-1069 ;-$, Is there any connection between the Eskimo languages and the Uralian? Atti del XXII Congresso Internaz. degli Americanisti, Roma 1928; vol. II, 551-67.

102) A. Rosenqvist, Lehr- und Lesebuch der finnischen Sprache, Leipzig 1925; 17, 24, 33 (noot 1), 34 v., 46, 47, 78; Fr. Müller, Grundrisz der Sprachwissenschaft II, 2, 202: A. Sauvageot, Esquisse de la langue finnoise, Paris 1946, 37, 84; Thomas A. Sebeok, Finnish and Hungarian Case systems: their form and function. Acta Instituti Hungarici Univ. Holmiensis B 3 (1946).

103) C. C. Uhlenbeck, Het passieve karakter van het verbum transitivum of van het verbum actionis in talen van Noord-Amerika, VAWA 1916, 187-216.

$\left.{ }^{104}\right)$ C. C. Uhlenbeck, Agens und Patiens im Kasussystem der Idg. Sprachen, IF 12 (1901), 170 vv.; -, Zur Kasuslehre, KZ 39 (1905), 528. Vgl. ook hier G. Royen, Die nominalen Klassifikations-Systeme in den Sprachen der Erde, op. cit. 864 vv.; A. Trombetti, Elementi di glottologia, op. cit., 264 vv. 
te worden weergegeven met „vanwege-dat-meisje (door d.m.) wordt daar een rok gemaakt" = dat meisje makt een rok. Maar in een intransitieve constructie met affixloos subject als le bakeam zou het luiden „,bij-die-man daar-loopt-het” = de man loopt. Juist zo in analoge tibetaanse constructies ; nas-byed „van-mij-uit wordt daar gemaakt” = ik maak; nas-btains „vanuit-mijn-overvloed schenk ik weg” = ik geef weg; $\dot{n} a s-m$ thon ,vanwege-mij wordt daar waargenomen” $=\mathrm{ik}$ zie. Maar veel meer globaal en ongedifferentiëerd bij een intransitief $\dot{n} a$ so $\dot{n}$ „,bij-mij daar-loopt-het” = ik loop ${ }^{\mathbf{1 0 5}}$ ).

Naar men ziet, heeft de transitieve subjectsaanduiding in de meeste hier bedoelde talen (niet in het fins) een suffix, dat de zoveel vagere intransitieve subjectsbepaling mist. Juist zulke, inderdaad niet zeldzame, gevallen hebben er nu Trombetti toe gebracht, de ergatief (d.i. het subject) in het algemeen tot ,una specie di nominativo enfatico" te verklaren (zie 78). Deze redenering berust o.i. echter op een petitio principii. De term ,nominatief” is dubbelzinnig. Trombetti vat cleze laatste uitdrukking, geheel in de stijl van zijn typisch ,activistische" opvattingen, in alle gevallen als dynamisch op. „Subject van een zin zijn” en ,een zekere dynamiek weergeven” zijn voor hem volkomen identiek. De suffixloze intransitivus van talen als miriam, tibetaans etc. drukt nu echter juist de in-actieve nuance uit. De vorm doet niet meer dan noemen. Men zou b.v. van een „casus appellativus” kunnen spreken. Daarom is de transitieve suffixvorm hier dus ook géén dynamisch subject-in-het-kwadraat, maar een gewone ergatief. De oppositie is niet „,dynamiek”: ,,nog meer dynamiek”, maar eenvoudig ,géén dynamiek”: „,wèl dynamiek".

b. Enigszins anders verloopt de redenering bij een groot aantal afrikaanse talen. Maar het resultaat is gelijk. Ook hier is de subjectskategorie blijkbaar enkel tot de uitgesproken dynamische gevallen beperkt. De minder gespecificeerde, niet-dynamische situatie steekt daar duidelijk tegen af.

Zo heeft men in de negertalen van de westelijke Sudan alleen bij de pronomina de keuze tussen een gewone serie deictische vormen en een andere, versterkte rij, die speciaal uitdrukt dat het subject waarlijk

105) In het fins heeft in dit geval de hoofddistinctie bijzonder merkwaardige vormen aangenomen; $\mathrm{J}$. Wils, De nominale klassificatie in de afrikaansche negertalen 173; A. Sauvageot, Esquisse de la finnoise, op. cit., 37 v.; 59, 84. 
dynamisch-actief optreedt. Bij de nomina vindt men slechts één stel dergelijke vormen ${ }^{106}$ ).

$\mathrm{Nu}$ doen de pronomina in dergelijke talen, waar het anaphorisch gebruik zulk een geringe plaats inneemt, practisch enkel dienst als aanduiding van menselijke personen. Dieren enz., die in de fabels als hoofdfiguur optreden, staan daarmee natuurlijk gelijk. Men kan dus veilig concluderen, dat hier de subjectskategorie aan het genus homo is gebonden. Zeker een gang van zaken die niet minder begrijpelijk is dan die van zoëven, toen speciaal de transitiva daarbij de primeur hadden! Waar kon immers de taalspreker dieper het „sentiment de pouvoir" doorleven, dat in dergelijke talen aan de subjectskategorie ten grondslag ligt, dan juist bij zijn eigen daden, resp. die van zijn personale partner? Het eigen actieve leven is hier onmiddellijk de school geweest voor de taal. Dit laatste is een eis, die Trombetti in zijn Elementi zeker terecht heeft gesteld (zie 78).

Voor de kuschitische talen van Noord-Oost-Afrika (behalve quara, bedja, bilin) hebben oorspronkelijk blijkbaar dezelfde distincties gegolden als voor de westelijke Sudantalen. De gang der redenering is in beide gevallen geheel dezelfde. In een voorgaande publicatie is daarover reeds gesproken ${ }^{107}$ ).

c. Zeer leerzaam voor ons doel is tenslotte ook de situatie in de Noord-Oostelijke kaukasustalen (awar, dido-andi-groep). Hier onderscheidt men als regel niet minder dan drie totaal verschillende verbale typen, met elk hun overeenkomstige vorm van subject ${ }^{108}$ ). Bij de „Empfindungsverba”, dat wil in dit geval zeggen die van gevoelsreacties en zintuigelijke waarnemingen, vindt men gewoonlijk een datiefconstructie. De actie wordt in dergelijke gevallen, naar Finck al heeft uiteengezet, blijkbaar aangevoeld als centripetaal. Gevoelens en waarnemingen worden van buiten uit opgewekt, en het „ik” blijft daarbij min of meer passief (71 v.). Awar dịe v-ok'ula emèn ,,mir lieb-

106) J. Wils, De nominale klassificatie in de afrikaansche negertalen; op. cit. 167-9.

107) J. Wils, Die Entwicklung des kuschitischen Kasussystems, Mélanges-Jacq. van Ginneken, Paris 1937; 311-329.

108) A. Dirr, Einführung in das Studium der kaukasischen Sprachen, Leipzig 1928, 62 vv.; H. Vogt, Esquisse d'une grammaire du géorgien moderne, Oslo 1936, 115-201; 38-54; A. Sommerfelt, Sur la notion du sujet en géorgien, Mélanges-Jacq. van Ginneken, Paris 1937, 183-185; C. Tagliavini, Osservazioni sull'ergativo georgiano, ibid. 187-192; F. Boas, Kwakiutl Grammar ; Transactions of the American Philosophical Society, NS 37, 3 (1947), 201-377. 
ist der-Vater”; diịe j-ok'ula ebèl ,,mir lieb-ist die-Mutter”; dun-v-ok'ula ebèlat'e ,ich lieb-bin der-Mutter" (= die Mutter liebt mich; een jongen spreekt), maar een meisje zou zeggen dan $j$-ok'ula ebèlat'e ,id.”. In de westerse talen wordt dit verbale type meestal centripetaal behandeld en dus met een nominatief geconstrueerd; al zijn er ook nog wel andere wendingen. Nedl. $i k$ meen naast mij lijkt, het komt mij voor; mnl. mi wetes; ik heb spijt naast het berouwt mij; lat. me poenitet; ik zie, constateer, inspecteer naast mij valt op; valt in het oog; lat. mihi videtur. Naast horen met een centripetale nuance staat luisteren dat meer actiefcentrifugaal is; naast genoegen nemen met staat evenzo bevredigd worden door; naast voelen, tasten staat bevoelen, betasten enz.

De „Tatverben”, die meestal transitief zijn, worden geconstrueerd met een ergatief. Geheel in overeenstemming daarmee staat het object hier in de gewone noemcasus (casus appellativus = inactief type van nominatief). De opvatting van de verbale handeling is nu dus wel centrifugaal. Geheel aanschouwelijk is de dynamiek echter nog niet. Het subject geldt als niet meer dan een zekere subjectieve organisatievorm, één der wegen waarlangs het resultaat tot stand komt, maar niet als het autonome centrum der actie. Awar dica razi ha-v-ùla emèn "durch-mich zufrieden $(r a z \hat{\imath})$-gemacht $(h a)$-wird der-Vater" = ich stelle den Vater zufrieden; dica razi ha-i-ìla ebèl ,ich stelle die Mutter zufrieden". Bij de intransitiva heeft men natuurlijk een gewoon nominativisch subject; dun v-it'una, ,ich gehe (Mann)"; dun j-it'una ,id. (Frau)" enz.

\section{B. De syntactische positie van het subject.}

Drukte het subject in de totnutoe besproken talen de personale dynamiek van de agens uit, een geheel nieuw aspect van deze kategorie komt naar voren in weer andere talen, n.l. haar bijzondere en specifieke syntactische functie. Inderdaad is de betekenis voor de zin bij het subject aanmerkelijk groter dan die van welk ander zinslid ook. Het object b.v. veronderstelt een zin, zet deze voort. Ook een genitief schept hoogstens een zinslid, een constructie dus die weer in een ander breder verband kan opgenomen worden. De verbinding van een subject is echter een $\operatorname{zin}^{108}$ ).

Welnu, juist zoals we hierboven talen hebben gezien, waarin de

109) J. van Ginneken, Taalkundige afdwalingen, Utrecht-Nijmegen 1923, 82; -, Eenvoudige taallesjes voor volwassenen, ibid., 87; O. Jespersen, Philosophy of Grammar 150 vv.; M. J. Langeveld, Taal en denken, Groningen 1934, 67-73; 
subjectskategorie vooral reageerde op de aanschouwelijkheid der verbale actie, zo zijn er nu ook verschillende andere, waarin speciaal de syntactische zijde daarvan naar voren komt. En juist zoals de meest oorspronkelijke oppositie in het eerste geval die was van ,actie”: „géén actie”, zo is die nu hier „,verbinding met de andere zinsleden”: „géén verbinding". In beginsel is dus in dergelijke talen het casusstelsel tweeledig. Welke kategorieën bij een dergelijke beperkte opzet het meest vaag van structuur blijven, is duidelijk: de meest gespecialiseerde, dat wil dus allereerst zeggen die van het subject zelf, en verder die van het object, de genitief enz. Met al de distincties die daartussen bestaan wordt geen rekening gehouden. Eenzelfde taalvorm, de positieve pendant van het gehele systeem, doet eenvoudig dienst voor al deze functies tegelijk.

a. Een dergelijk primitief, maar toch wel begrijpelijk systeem vindt men b.v. nog in de berberdialecten van Noord-West-Afrika. Aan het tweede, dominante lid van een syntactische constructie wordt hier $u$ voorgevoegd. Of het daarbij in grammaticaal opzicht over een subject, een genitief, of over een voorzetselconstructie gaat, is volkomen onverschillig. Basset en zijn school spreken daarom hier met een fraaie term van een algemeen „rapport d'annexion" ${ }^{110}$ ). Men ziet, hoe uiterst vaag nu dus nog de structuur van de zin is. Wil men dit ook in de vertaling laten uitkomen, dan zijn de meest eenvoudige formuleringen nauwelijks adaequaat. Shilh van Tazerwalt: tigime u-gellid ,bij-dat-huis daarkoningt-het" = het huis des konings, het paleis; $d$-u-gellid ,met den koning"; maar evengoed volgens hetzelfde schema iffug u-gellid ,hetging-daar-uit bij-dien-koning" = de koning vertrok. Staat echter het subject voorop in een constructie als deze laatste, komt hier m.a.w. zelfs de beschreven vaag-dynamische verbinding met het praedicaat niet tot stand, dan treedt direct ook weer de negatieve pendant van het stelsel op, en de copulatieve index blijft weg. A-gellid iffug ,daarkoningt-het daar-ging-het weg".

Ook de obliquus op $-n(\ddot{a})$ van het kaukasische ubych vervult, volgens

D. Haagman, Subject en Object, Nieuwe Taalgids, dl. X (1916), 161-182. Zie ook hierboven 91 , noot 1 .

110) R. Basset, Manuel de langue kabyle, Paris 1887, 61; E. Laoust, Cours de berbère marocain, Paris 1921, 38. Vgl. ook H. Stumme, Handbuch des Shilhischen von Tazerwalt, Leipzig 1899, 44 vv.; E. Westermarck, Nomina im Status absolutus und Status annexus in der süd-marokkanischen Berbersprachen, Oefersigt of Finska Vetenskaps-Societetens Förhandlingar, Bd. 66 (1913-'14), Afd. B. Nr. 3. 
Dirr, naargelang de omstandigheden, nu weer eens de taak van een ergatief (als subjectscasus bij de transitiva), en dan weer die van een genitief, een datief, een ablatief, een elatief, een locatief, een comitatief, en zelfs van een comparatief. De suffixloze „nominatief”, die daartegenover staat, komt alleen voor bij de intransitiva als subject, en verder bij de transitiva als object ${ }^{111}$ ). Blijkbaar is deze negatieve pendant van het gehele systeem dus ook hier weer niets anders dan een uiterst vage, algemene adverbale bepaling, waarbij het overgaan van de verbale actie niet of nauwelijks is gegeven, en die dus ook vrijwel los staat van het verdere syntactische verband. B.v. si-j'il'an $\gamma \varepsilon$-cäk'i „Meinem-Bruder(j'il'a) sein-Zahn”; sayoà si-nk'än jexest'h'oлqafasin „ich meinem-Freund(nik'ä) als-ich-schrieb”; səyoà wana a-bzin wäsu

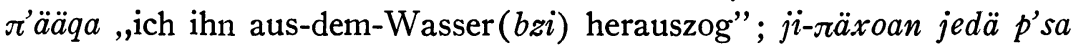
wel ,in-diesem-Flusz ( $\pi \ddot{x} x o a$ ) viel Fisch es-gibt”. In het verwante kabardi schijnt de toestand ongeveer dezelfde te zijn.

b. In andere talen is er althans in zoverre verdieping gekomen in de syntactische structuur, dat de ongedifferentiëerde „rapport (état) d' annexion" nu in tweeën gesplitst wordt. Men onderscheidt tussen de nauwer en de minder nauw verbonden typen. En tegenover dit dubbel stel van erfgenamen staat dan, als negatieve pendant, nog de algemene subjectsbepaling, die we zoëven reeds hebben gezien, en waarbij het verband met het praedicaat niet of slechts in zéér geringe mate wordt uitgedrukt. Als geheel is het casussysteem nu dus drieledig.

Dat het subject in dergelijke talen in de hoogste sector der nauwst verbonden casustypen terecht komt, behoeft na het voorgaande wel niet meer apart gemotiveerd. Gewoonlijk hoort daar verder ook de genitief Men ziet, welk een winst zulke reeds enigszins ontwikkelde systemen betekenen. Het zinsschema is veel scherper geleed en vertoont aanmerkelijk meer reliëf dan bij de onder a. genoemde talen. De opvatting is aan de andere kant echter blijkbaar nog vrij vaag van aard, en met name het specifieke dynamische en totaliserende moment dat de subjectskategorie kenmerkt, óók tegenover de genitief, wordt hier nog niet expliciet uitgedrukt.

In de europese vertaling kan men van zulke genitief-subjecten (of juister wellicht: subjectsbepalingen in de vorm van een genitief) een vrij goed idee krijgen. Ook in onze jongere en oudere cultuurtalen

111) A. Dirr, Die Sprache der Ubychen, Caucasica 4 (1927), 74 vv.; -, Einführung in das Studium der kaukasischen Sprachen, Leipzig 1928, 40, noot 3. 
wordt de agens van een verbale actie n.l. herhaaldelijk op deze wijze aangeduid, en wel overal waar diens figuur, om welke redenen dan ook, min of meer op de achtergrond blijft. Voorbeelden daarvan vindt men hierachter (137).

Duidelijke voorbeelden van een genitivische subjectsbepaling, als hoogste pendant in een overigens drieledig casusstelsel, heeft men ook in een aantal tibeto-birmaanse dialecten ${ }^{\mathbf{1 1 2}}$ ). In het tibetaans in engere zin fungeert als zodanig b.v. bij de nomina de vorm op -kyi $(s)$, -gyi $(s)$, $-g i(s)$ enz. In een transitivisch-verbale constructie wijst deze op het subject, dat hier in de instrumentalis staat; in een nominale verbinding echter op de genitief. $N^{\prime} a$-s byed "vanwege-mij maakt-het-daar" = ik maak; $\dot{n} a-s$ btains ,van-mijn-kant werd-daar-weggeschonken” $=\mathrm{ik}$ gaf ; maar eenvoudig $\dot{n} a$ son „bij-mij daar-ging-het” = ik ging. Mig-gi(s) „,van het oog, vanwege het oog”; lus-kyi(s) „van den kant van het lichaam, seitens des Körpers".

Toch begint hier aan de andere kant blijkbaar ook wel reeds enig gevoel te ontwaken voor de speciale syntactische betekenis van het subject. Komt er n.l. in de zin een dubbele aanwijzing voor, èn van de personale agens èn van het door hem gebruikte instrument, dan wordt de $k y i(s)$-vorm liever vermeden, zo deelt Francke mee ${ }^{113}$ ). Voor het levenloze instrument voegt men dan verder gewoon de praepositie $d a \dot{n}$,with" toe. „The meaning of the sentence becomes clearer (in this way)". Rgyal-pos-mi-ni-gri-yis (of dain)-bsad „the king (rgyal) killed the man (mi) with the knife (gri)".

Naast de genitief-instrumentalis staan dan verder in het tibetaans nog een datief, een locatief, een ablatief en een terminatief. De datief op -la kan ook vaak optreden als locatief of terminatief. De inheemse grammatica vatten deze drie laatste kategorieën daarom ook samen als ,la-don-cases, i.e. the cases which have all the meaning of $l a$ ". Dit wijst wel op diepere structurele samenhang; en men zal zeker niet ver van de waarheid zijn, als men de ,la-don-cases" daarom ook in de boven beschreven zin, als minder nauw verbonden casus stelt tegenover de genitivische subjectsbepaling die de pendant van de hoogste graad is.

En tenslotte is er dan in het tibetaans nog de suffixloze woordstam, die juist als zoëven in het ubych en het kabardi, enkel als subject bij

112) Jäschke-A. H. Francke, Tibetan grammar 21-24; J. Bacot, Grammaire du tibétain littéraire, Paris 1946, 23.

113) Jäschke-A. H. Francke, Tibetan grammar 114 v. 
de intransitiva of als object bij de transitiva kan optreden. Dit is dus de laagste trap van de gehele driedeling: de puur-negatieve pendant (mig ,het-oogt-daar”; lus ,daar-is-gelichaam”).

Ook in het oudste indo-europees, dat we met onze reconstructie kunnen bereiken, bestond er volgens van Wijk's bekende hypothese géén onderscheid tussen de casus transitivus en de genitief, evenmin als in het tibetaans. In beide gevallen fungeerde de z.g. „,casus agens” op $\left.-s^{114}\right)$. Alleen in de verdeling van het accent in de gevormde constructie was er enig onderscheid. In de verbale verbinding lag de voornaamste druk op de stam; maar in de nominale verbinding, waar het nomen rectum vooropstond, op de uitgang. En tegenover de casus agens stond dan ook hier weer als derde, blijkbaar negatieve pendant van het stelsel een ,casus patiens" op - $m$, waarbij de verbale actie niet aanschouwelijk was, d.w.z. opnieuw als subject bij de intransitiva maar als object bij de transitiva.

Over de $p$ - of $m$-casus der eskimotalen van Groenland, Labrador en Alaska, die eveneens weer een genitief-transitivus is, zie men Uhlenbeck, Karakteristiek der baskische grammatica, VAWA 4, 8, 28-36; F. N. Finck, Die Grundbedeutung des grönländischen Subjectivs, SBPA 1905; IX; A. Trombetti, Elementi di glottologia 182 vv. Verdere literatuur bij G. Royen, Die nominalen KlassifikationsSysteme in den Sprachen der Erde 932, 868. W. Thalbitzer, Eskimo in Handbook of American Indian Languages I (1911), 967.

Met het oog op het debat over de flectietypen, dat we hierboven uitvoerig beschreven hebben, zijn deze laatste drie typen van genitivische subjectsbepalingen wel interessant. Het transitieve werkwoord is hier immers duidelijk èn passief èn ,possessief" tegelijk. Tussen de genitief en de transitief (ergatief, alblatief) wordt nu in de taal geén onderscheid gemaakt. Schuchardt heeft dergelijke overgangs- of kruisingsvormen helaas niet apart gehouden bij zijn studie der kaukasische talen, hoewel ze ook daar voorkomen, en wel naast de verder ontwikkelde, zuivere ,passieve” typen ${ }^{\mathbf{1 1 5}}$ ). Voor het kabardi en het ubych, waar de oorspronkelijke distincties secundair blijkbaar nog meer complex zijn geworden, zie men b.v. hierboven p. 90, 94 v. Later nog is Schuchardt

114) N. van Wijk, Der nominale Genitiv Singular im Indogermanischen in seinem Verhältnis zum Nominativ, (Diss. A'dam), Zwolle 1903.

115) H. Schuchardt, Ueber den passiven Charakter des Transitivs in den kaukasischen Sprachen, SBAWW 133 (1895), Abh. 1.

Verh. dl. XII. 
in debat geraakt met Finck over de historische verhouding van de „passieve” en de „possessieve” typen. Wat daarvan verder ook zij, deze beide typen schijnen elkaar duidelijk meer na te staan, dan men het gewoonlijk wel voorstelt ${ }^{116}$ ).

\section{De waarderingsfactor.}

De derde betekeniscomponent van de subjectskategorie, die we thans nog moeten bespreken, hangt waarschijnlijk nauw samen met de eerste factor. Hij houdt niet anders in, dan dat de agens van de zijde der taalsprekers in het algemeen een bijzondere waardering geniet. Men kan dit feit ook wel verstaan. Het autonome centrum van de handelingssituatie trekt uiteraard het meest de aandacht, en op de meerdere aandacht is als vanzelf de meerdere waardering gevolgd. Dit zijn de gevallen, waarop o.a. Schuchardt en Trombetti gewezen hebben, en waarin de subjectsaanduiding in de taal als teken van de speciale emphase ook een aparte pronominale versterking krijgt. Schuchardt vertaalt b.v. in een dergelijk geval „Vater-er; c'est le père qui....”; en wijst verder op vormen als indo-europees $-s$, semitisch $-u$ bij het subject enz. ${ }^{117}$ ).

Ook in deze typische waarderingsfactor ligt ongetwijfeld één van de voornaamste redenen, waarom in een groot aantal talen van de wereld de verder ontwikkelde vormen van subject aanvankelijk tot bepaalde nauw omschreven groepen van nomina beperkt zijn gebleven. In de negertalen en de kuschitische talen van het zwarte werelddeel, alles bijeengenomen zeker dus enige honderden van talen, konden b.v. oorspronkelijk alleen de menselijke personen zelf als autonome agens in de taal worden aangeduid. We hebben dit reeds gezien (91 v.). Vgl. ook hierachter 191. Bij namen van dieren of van inanimata kent men hier niets dan een vage instrumentale bepaling.

In weer andere talen keren analoge distincties terug. Zo kunnen bijv. in het japans de namen van inanimata ook thans nog niet optreden

116) Vgl. ook hierachter 143 vv.

117) H. Schuchardt, Ueber den aktivischen und passivischen Character des Transitivs IF 18, 528-31; A. Trombetti, Elementi di glottologia, op. cit. 671; 264 v.; Vgl. ook F. Bopp, Ueber das Demonstrativum und den Ursprung der Casuszeichen, ABAWB 1826, 65-102; Fr. Müller, Grundrisz der Sprachwissenschaft $3,2,530,343$. 
als subject van transitiva ${ }^{118}$ ). Een dergelijke taalkundige machtspositie zijn zij a.h.w. niet waardig. Zouden ze door de loop der feiten daarin toch komen te verkeren, dan dient men ter omschrijving een intransitieve tournure met een instrumentale subjectsbepaling te kiezen waarin de inanimata wel passen. Een franse wending als „Le tonnerre m'a épouvanté" kan b.v. niet rechtstreeks in het japans worden vertaald, naar Balet meedeelt. Men dient te zeggen kaminari ni odoroita ,j'ai été effrayé par le tonnerre". Officiële bureaux en publieke lichamen staan echter hoog genoeg in de waardering om dragers van het ,sentiment de pouvoir" te kunnen zijn. Dergelijke vormen kunnen daarom wel als transitief subject fungeren, al ziet men eigenlijk ook dan nog liever een intransitieve constructie.

Aan de andere kant worden trouwens ook animata in het japans niet onbeperkt toegelaten tot de gewichtige subjectsfunctie bij de transitiva. Zou b.v. een ,être inférieur quoique vivant” in een bepaalde situatie in een min of meer actieve rol tegenover de superieure mensen worden gesteld, dan is onmiddellijk weer het gebruik van een passiefintransitieve constructie aan te bevelen. Bij een directe, transitieve tournure zou het meerdere in waardering en aandacht anders immers wellicht voor het mindere moeten wijken. Nomi ni kui-saserareta „une puce m'a piqué" = lett. j'ai été piqué par une puce.

\section{De nominatief als basis van het gehele casussysteem.}

We hebben totnutoe nog slechts vrij eenvoudige typen van subject leren kennen, typen waarbij de kategorie uitsluitend berustte òfwel op de aanschouwelijk geworden personale actie òf op de syntactische betekenisfactor. Er zijn echter ook wel talen, waarin deze beide oeroude componenten gaan samenwerken en daardoor elkander tot krachtiger leven brengen. Daarmee is pas, althans in zekere zin, „het grote uur” voor de subjectskategorie gekomen. $\mathrm{Zij}$ wordt nu de eerste onder de casus, de basis van het gehele systeem. En men kan zeggen, dat de andere casus telkens eerder tot haar in oppositie staan, dan wel tot elkander ${ }^{\text {d19 }}$ ).

Een eerste voorbeeld van een dergelijk twee-dimensionaal stelsel

118) C. Balet, Grammaire japonaise, Paris 1925, 231, 273.

119) G. Guillaume, Esquisse d'une théorie psychologique de la déclinaison, Acta Linguistica 1 (1939), 167; Herbert Penzl, On the cases of Afghan (Pashto) Noun, Word 6 (1950), 70. 
heeft men in het australische awabakal („Lake Macquarie”). Hier staat in het casusstelsel allereerst een casusactivus tegenover een casusinactivus. De eerste voegt een teken $-k o$ toe aan de stam, de tweede is suffixloos. Verder heeft men hier nog, volgens Fr. Müller, een genitief, een datief, een socialis, een abessief, een adessief etc. ${ }^{120}$ ). Het grootste deel van al deze casus wordt nu echter gewoonlijk van de activus afgeleid. Telkens worden twee suffixen achter elkaar geschakeld: Voorop staat dat van de activus, een pas daarop volgt het eigen teken van de betreffende naamval zelf. De inactivus daarentegen staat blijkbaar min of meer buiten het systeem. Van de stam kore- „Mann” heeft men b.v. inactivus kore; activus kore-ko; maar verder nu zo ook genitief $k o r e-k o-b a$; datief $k o r e-k o$ (het volledige samenvallen met de activus is hier toevallig); socialis kore-ko-a; adessief kore-ka-ko; abessief kore-ka-birun enz.

Men ziet, hoe glashelder door een dergelijk paradigma wordt geillustreerd hetgeen hierboven reeds gezegd is over de verhouding van de beide componenten der subjectskategorie. Met het subject krijgt de spreker ook de sleutel in handen voor het verdere verloop van de zinsbouw. Deze komt door dit ene feit, en alles wat zich daaraan vastknoopt, plotseling als op een hoger plan te staan. Aan allerlei kanten neemt de geleding aan duidelijkheid toe. Alleen dient daarnaast natuurlijk onmiddellijk te worden toegegeven, dat de bouwtechniek zelf in het awabakal nog vrij primitief is. De beheersing en de geleding van de totale, zich ontwikkelende zinsstructuur is nog allesbehalve vlot en vrij. Geen enkel volgend element kan a.h.w. tot uitdrukking komen, zonder dat met een enkel teken $(-k o)$ eerst weer even aansluiting is gezocht bij de initiale notie van het subject, waarvan de gehele structuur is uitgegaan.

Ook in het awar en het lak, twee noord-kaukasische talen, zijn de beide elkander kruisende assen van het casusstelsel nog duidelijk gescheiden ${ }^{121}$ ). Alleen staan hier nu niet een activus en een inactivus tegenover elkaar in het eerste bouwplan, maar een transitivus (ergatief) en een intransitivus. Voor ons doel is deze laatste nuance irrelevant.

120) Fr. Müller, Grundrisz der Sprachwissenschaft II, 4 vv.

121) A. Dirr, Einführung in das Studium der kaukasischen Sprachen 163, 238 vv.; Trombetti, Elementi 265. 


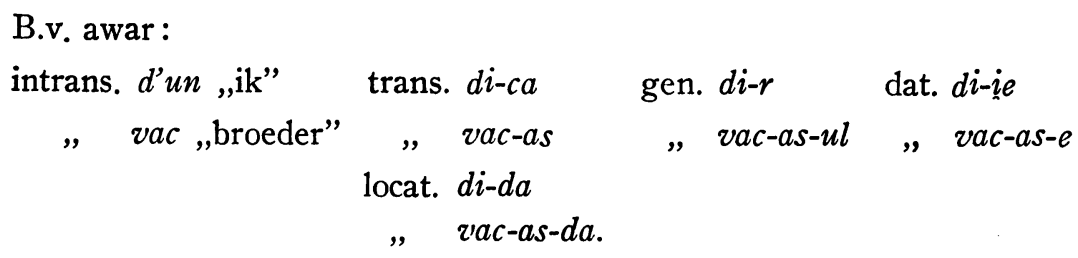

In naburige talen als het tabassaran, bats, hurkan etc. ziet men de transitief echter reeds hoe langer hoe meer terrein winnen, ook bij de „Empfindungs”- of „Dativverba”, waarover hierboven reeds kort gesproken is (92 v.), en waar dus aanvankelijk een geheel ander subjectstype gold. Het transitieve verbale type gaat hoe langer hoe meer de toon aangeven.

Trombetti wil uit gevallen als dat van het awar afleiden, dat de ergatief (transitief) „non è un caso, ma un tema”. Vgl. hierboven $78 \mathrm{v}$. Men zal dit oordeel zeker kunnen overnemen. Zowel bij de nomina als bij de pronomina worden de casus hier van de transitieve suffixvorm afgeleid, en niet van de stam. Op de factor der dynamische activiteit zal deze voorrangspositie echter niet berusten, zoals blijkbaar Trombetti's bedoeling is. Het is immers juist dit element, dat het subject van de andere casus scheidt en differentiëert. Hoe zou op deze wijze dus ooit een vast en gesloten systeem kunnen zijn ontstaan? De band ligt hier veeleer in de syntactische component die we zojuist op de tweede plaats hebben behandeld. Daarin delen de andere casus alle, en elk weer op eigen wijze. En zo konden deze dus nu wèl vanuit hetzelfde gezichtspunt worden overzien ${ }^{122}$ ).

Een derde voorbeeld van een gemengd casusstelsel leveren de dravidatalen. Ook hier is de aanvankelijke distinctie in de onderbouw blijkbaar die geweest tussen een transitivus en een intransitivus. Later echter werd dit onderscheid langzaam maar zeker opgelost, althans op een deel van het terrein, omdat het transitieve werkwoordstype werd veralgemeend. En zo vindt men hier thans enerzijds talen, waarin een suffixloze stam staat naast een speciale ,inflectional base”, maar anderzijds ook andere, duidelijk van moderner signatuur, waarin dit

122) In een dergelijk verband zullen ook wel de gevallen uit het georgisch, bongu etc. passen, waarop Trombetti wijst (Elementi 265), en waarbij men met een ergatief antwoordt op een vraag. Uit zulke overgangstalen conclusies te willen trekken aangaande de aard van den ergatief, is daarom wel gevaarlijk. 
onderscheid niet meer gemaakt wordt ${ }^{123}$ ). Soms komen de beide vormingstypen zelfs broederlijk in een en dezelfde taal naast elkander voor; zo b.v. in het kui, waar Winfield de ,inflectional base" zonder meer als genitief behandelt ${ }^{\mathbf{1 2 4}}$ ).

$\begin{array}{lc}\text { Nom. neganju ,a good man” } & \text { maar }\} a b a, \text {,father, of father” } \\ \text { Gen. negani } & a b a-i \\ \text { Acc. negani-i } & a b a-k i \\ \text { Dat. negani-ki } & a b a-k e \\ \text { Assoc. negani-ke } & a b a-(\text { rai }) \\ \text { Abl. negani }(-r a i) & \end{array}$

Andere goed bestudeerde voorbeelden van dergelijke secundair veralgemeende subjectstypen heeft men tenslotte nog in de oudere indo-europese talen. Naar het algemeen gevoelen der deskundigen staan de intransitiva hier doorlopend onder zeer zware druk van de zijde der transitiva. Men denke aan constructies als skr. vana-m gacchāmah „wij gaan naar het bos"; lat. eo Romam etc. Ook in een antal oeralaltaische talen (samojeeds, fins, manchu, tungus, mongools, jakutisch, turks) en in enkele daarbij aansluitende andere talen (kottisch, jenisseiostjak) schijnt ditzelfde voor te komen ${ }^{125}$ ). De subjectsaanduiding zelf voert in deze laatste gevallen meestal geen speciaal distinctief teken; de casus obliqui worden door middel van suffixen gevormd. Bij pronomina komen op deze wijze soms zelfs twee geheel verschillende stamtypen naast elkander voor. Zo b.v. manchu $b i$,ik" maar gen. min-i; dat. min-de; acc. min-be; abl. min-tši enz. Dit laatste verschijnsel is eveneens weer uit de indo-europese talen bekend. In de nominatief van het personale van de eerste persoon enkelvoud stammen de vormen hier b.v. van *egh (skr. ahám; gr. $\dot{\varepsilon} \gamma \omega \dot{\omega}$; lat. ego enz.), maar de casus obliqui van $m e$ (gr. $\mu \varepsilon$; lat. $m e$. etc.).

123) R. Caldwell, A comparative grammar of the Dravidian or South-Indian family of languages ${ }^{3}$, London 1913, 259 vv.; J. Bloch, Structure grammaticale des langues dravidiennes, Paris 1946, 10-17.

124) W. Winfield, A grammar of the Kui language; Calcutta 1928, 25 vv.

125) Fr. Müller, Grundrisz der Sprachwissenschaft II, 12; 202, 268; H. Winkler, Die altaische Völker- und Sprachenwelt 57 vv.; J. Deny, Langues turques, langues mongoles et langues tongouzes (in A. Meillet-M. Cohen, Les langues du monde, Paris 1924, 209, 213, 228 v.) ; J. Wils, De nominale klassificatie in de afrikaansche negertalen 151-154 (noot). 
Wat ontwikkelingen als deze laatste in zuiver theoretisch opzicht betekenen, is duidelijk. Géén van de drie besproken kategoriale componenten blijft bij de veralgemening van het transitieve constructietype in zijn oorspronkelijke waarde en kracht bewaard. Bij een intransitivum blijft de handeling geheel tot de persoon van het subject beperkt (rex super thronum sedet); bij een praedicatieve verbinding is zelfs in het geheel niet van een handeling sprake (rex caput civitatis). Als dergelijke constructies nu regelmatig enkel naar het transitieve model worden behandeld en geïnterpreteerd, dan blijft er van de personale dramatiek die in dit laatste geval inderdaad bijzonder sprekend was (rex interficit servum), natuurlijk practisch niet veel meer over. Eén van de voornaamste grondslagen der subjectskategorie komt daarmee dus ten val. In dezelfde mate lijdt echter ook de syntactische component, die van de vorige niet te scheiden is. En zeker kan dan van de waarderingscomponent ook hetzelfde worden gezegd, voorzover die ooit van de kategorie deel heeft uitgemaakt. De subjectskategorie is in dergelijke verder ontwikkelde talen m.a.w. een vrijwel puur abstracte grootheid geworden, het eerste lid van een bepaald syntactisch schema waaraan alle zinstypen in beginsel zijn onderworpen, maar waaraan buiten de orde der taal niet veel meer beantwoordt.

J. van Ginneken heeft, van taalpsychologisch standpunt, deze situatie voor het moderne nederlands reeds in een klein maar zeer belangrijk artikel geschetst. In een taal als de onze, zo zegt hij, kan men de verhouding van subject en praedicaat onmogelijk meer karakteriseren als die van ,agens" tot ,handeling”. Men beweegt zich hier thans in een geheel andere orde: die van het verloop der gedachte zelf. Allerlei nuances zijn daarbij mogelijk. $\mathrm{Nu}$ eens kan men het subject het best als het „beginpunt" der gedachte beschouwen, waarvan het praedicaat dan het „eindpunt” voorstelt. Dan weer is het beter van ,aanloop” en ,sprong” te spreken, of van „bijzaak” en „hoofdzaak” ${ }^{126}$ ). Men begrijpt, waarom de termen hier steeds wisselen. De eigenlijk kern van de verhouding blijft ongrijpbaar, omdat deze volkomen onaanschouwelijk is. Het theoretische syntactische schema is volkomen „leeg”,

126) J. van Ginneken, Taalkundige afdwalingen, op. cit. 82. Zie ook H. Delacroix, Le langage et la pensée ${ }^{2}$, Paris 1930, 219-25; V. Mathesius, Zur Satzperspektive im modernen Englisch, Archiv für das Studium der neueren Sprachen 155 (1929), 202. 
en het wordt, naargelang de omstandigheden, telkens weer op andere wijze ,ingevuld”.

Het grote voordeel van een dergelijke ontwikkeling spreekt intussen vanzelf. Het taalsysteem is nu naar verhouding veel eenvoudiger geworden. De kategorie heeft meer algemeen-geldigheid verkregen. Men stoot niet meer voortdurend op allerlei grenzen en bepalingen in gebruik of betekenis, zoals dit bij de meer primitieve subjectstypen steeds het geval is. Maar de prijs, die voor deze grotere algemeenheid werd betaald, is ook wel hoog! De kategorie mist nu voor een goed deel haar natuurlijke basis. De afstand tussen leven en taal is aanmerkelijk vergroot. De tong moet spreken hetgeen het hart niet meer voelt of het oog niet meer ziet. En achter de winst der hogere abstractie loert dus duidelijk het spook der verstarring, die op de duur kan leiden tot de dood.

HOOFDSTUK $\mathrm{X}$.

\section{De structuur van de objectscategorie.}

Aan de greep der valse philosophische en psychologische reminiscenties die de leer over het subject hebben beinvloed, en die we hierboven uitvoerig hebben beschreven, is natuurlijk ook de opvatting aangaande het object niet ontkomen. Men kent de gewone, zeker vaak onbewust aangehangen theorie. Het object zou niets anders zijn dan de taalkundige representant van de grootheid waarop de door het subject gestelde handeling ,overgaat”. Ieder transitief werkwoord kan dus ook een object bij zich hebben, en de aanwezigheid daarvan kan enkel reeds door een logische analyse onmiskenbaar worden vastgesteld. Transitiviteit, d.i het combineerbaar zijn met een object, geldt bij het werkwoord juist zo als een vast en onbetwistbaar lexicologisch kenmerk als b.v. bij het substantief het onveranderlijke woordgeslacht dit is. Ook met de z.g. ,inwendige" objecten dient men daarbij rekening te houden (type: een droom dromen; de slaap des rechtvaardigen slapen). Alle typen van object in de talenwereld staan op één lijn en kunnen onmiddellijk met elkander worden vergeleken. Het subject en het object zijn, aldus gezien, in beginsel dus ook geheel gelijkwaardige en correla- 
tieve kategorieën. Het onderscheid is alleen dat de eerste kategorie op de initiale phase der handeling betrekking heeft, maar de tweede op de slotphase. Juist hetzelfde geldt, mutatis mutandis, voor de ,actieve” en de ,passieve” genera verbi, die daarmede corresponderen, en die geheel vrij en onbeperkt omkeerbaar zijn.

Ook nu kan men weer het best wijzen op Trombetti, als de meest overtuigde woordvoerder der „logicisten” en der ,activisten”. „L'oggetto”, zo schrijft de geleerde italiaan ${ }^{127}$ ), ,esprime il termine al quale passa (transit) l'azione dei verbi transitivi, il termine ad quem di un moto reale o ideale, cioè il passaggio dell'azione dal soggetto all'oggetto stesso. Tale moto nell' espressione passiva è concepito in senso inverso:

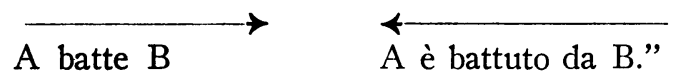

Men ziet, dat het hier uitdrukkelijk over een regel zonder uitzonderingen gaat.

Wat speciaal de indonesische talen betreft, hebben merkwaardigerwijze echter ook ,activisten” als Tendeloo, Jonker e.a. reeds duidelijk gevoeld, dat het onderscheid tussen transitiva en intransitiva hier in ieder geval vrij vaag is. Tendeloo noemt deze distinctie voor de maleise grammatica b.v. ronduit ,volkomen waardeloos”. Consequenties worden aan deze gedachte echter niet verbonden ${ }^{128}$ ).

Waarom de aangevoerde argumenten niet als doorslaggevend kunnen gelden, behoeft nauwelijks opnieuw te worden betoogd. De beschreven redenering berust geheel op extra-linguistische gegevens, en is voor de taalkundige dus niet ad rem. Ook hier dient onze analyse m.a.w. allereerst weer zowel de logische als de zuiver pragmatische bakens te verlaten en geheel naar eigen stijl te worden doorgevoerd. Onze vraag komt aldus te luiden: Welke typen van object komen de facto in de verschillende talen der wereld voor? Welke structuur vertonen deze? En hoe is hun verdere ontwikkeling geweest? Welnu, vanuit dit gezichtspunt bezien, dient men, naar het ons voorkomt, in de objectskategorie oorspronkelijk weer juist hetzelfde drietal componenten te onderscheiden als we hierboven bij het subject hebben gezien.

127) A. Trombetti, Elementi di glottologia; op. cit., 266.

128) H. Tendeloo, Maleische grammatica, II, 172. 
A. De dynamiek in de slotphase der verbale handeling.

De eerste component houdt in, dat de objectskategorie uitdrukkelijk de genoemde grootheid als door de verbale handeling ,getroffen" voorstelt. Het is dit „object”, dat de slotphase daarvan een zeer bijzondere vorm van anschouwelijkheid verleent. Deze min of meer "passief” gerichte component is het dus, die door de "activistische" leer als voldoende en als steeds aanwezig wordt beschouwd. Dominus percutit servum. Venator interficit leon-em enz. Dat de ,activistische” eis ook op dit punt te hoog gesteld is blijkt echter duidelijk uit de feiten. Ook hier treft men weer in allerlei talen kernen in het gebruik aan, waarbuiten de kategorie nog niet is doorgedrongen. Men zal hier dus practisch heel wat meer overgangen en gradaties moeten aannemen, dan de orthodoxe leer wel kent.

a. Zo is b.v. het gebruik van het objectssuffix in de moderne dialecten van het turks strikt tot de definiete gevallen beperkt ${ }^{129}$ ). Alleen wanneer het logische object de spreker volkomen aanschouwelijk voor ogen staat, wordt dit door hem ook taalkundig als zodanig gekenmerkt. Blijft het object, om welke reden dan ook, min of meer vaag of algemeen, dan gebruikt men de casus indefinitus zonder suffix. Kitab aldiñiz-mi? „Haben Sie Bücher gekauft?” maar Kitab-i aldiñiz-mi? „Haben sie das Buch gekauft?” Askär görmädim „Ich habe keine Soldaten gesehen” maar askär-lät-i görmädim „Ich habe die Soldaten nicht gesehen". Zo ook zonder suffix constructies als kädi säurormisiñiz „Lieben Sie Katzen?” šarab ič-mek ,boire du vin”; pyano čal-maq „,jouer du piano”. K. Grönbech heeft in een fijne, comparatieve beschouwing aangetoond, hoe het in dergelijke gevallen in de grond om een vermeerdering van de aandacht en een vergroting van de aanschouwelijkheid gaat. Dit komt dus geheel overeen met de bovenstaande analyse. Het suffix wordt alleen toegevoegd, zo zegt hij, als aan het object ,ein selbständiges Interesse zukommt”. Het dient om het object „,dem Tatwort gegenüber.... grösseren Nachdruk und Selbständigkeit.... zu verleihen". Zelfs in de Orchoninscripties kan men de invloed van deze regel reeds aantonen.

129) G. Weil, Grammatik der osmanisch-türkischen Sprache, Berlin 1917, 220; J. Deny, Grammaire de la langue turque (dialecte osmanli), Paris 1921, 183-5; K. Grönbech, Der türkische Sprachbau, Kopenhagen 1936, 155-68. 
Blijkbaar verwant aan de besproken turkse distinctie, alleen veel meer gesystematiseerd en gerationaliseerd, is het onderscheid dat er in het hongaars bestaat tussen de z.g. subjectieve conjugatie en de objectieve vorm. Var-ok ,ich erwarte” maar var-om „,ich erwarte ihn”; ker-sz „du-bittest” maar ker-ed „du bittest ihn”. De intransitieve vorm is enkel voor de handeling in het algemeen bedoeld ${ }^{130}$ ).

b. Een bijzonder geval van een dergelijke vermeerdering of vermindering van de aanschouwelijkheid heeft men ook bij de wisseling van het verbale tempus of aspect. Bij het terugblikken op het verleden verliest de oorspronkelijke dynamiek natuurlijk voor een goed deel het sprekend karakter dat deze in het actuele heden nog wel bezat ${ }^{\mathbf{1 3 1}}$ ). Vandaar dat b.v. in een taal als het baskisch in het praesens aan een transitieve vorm steeds zowel een subjectsteken als een objectsteken dient te worden toegevoegd. Het eerste staat als suffix achter de stam, het tweede als prefix ervóór. De verbale handeling is nu dus in haar volle verloop aanschouwelijk. Maar in het praeteritum kan het objectselement ook wegblijven. Het werkwoord wordt dan verder volledig als een intransitivum behandeld. De verbale dramatiek wordt niet meer doorleefd. $D-a-k a r-t$,ich trage ihn”; $d-a-k a r-k$,du trägst ihn (masc)"; maar n-ekar'-en, n-enkar'-en ,ich trug" (-en tempusteken), juist zoals het ook luidt n-etor'-en, n-entor'-en ,ich kam". Met objectstekens daarentegen $n(1)$-enkar-su(2)-n ,du trugst mich (höflich)"; $n$ (1) -enkarte-te(3)-n ,sie trugen mich".

Ook in het georgisch komen dergelijke distincties voor. Het zijn nu vooral de naamvallen, die hier de speciale opvattingsrichting van de spreker verraden ${ }^{\mathbf{1 3 2}}$ ). Zo staat hier het transitieve subject in het praesens steeds in de nominatief, maar het object in de datief-accusatief op $-s(a)$. De overgang van de handeling is nu dus aanschouwelijk. De opvatting is zoals b.v. in het latijn of het moderne duits. In het

130) S. Simonyi, Die ungarische Sprache, Strassburg 1907.

131) E. Koschmieder, Zeitbezug und Sprache, Leipzig 1929, 11; 26 vv.; G. Guillaume, Immanence et transcendance dans la catégorie du verbe. Esquisse d'une théorie psychologique de l'aspect; Psychologie du langage, Paris 1933, $355 \mathrm{vv}$.

132) G. Dumézil, Etudes comparatives sur les langues caucasiennes du NordOuest, Paris 1932, 41 vv.; 173 vv.; 209 vv.; -, Introduction à la grammaire comparée des langues causasiennes du nord, Paris 1933, 99-122; H. Vogt, Esquisse d'une grammaire du géorgien moderne, Oslo 1936, 130, 132, 135, 222 vv. A. Dirr, Einführung in das Studium der kaukasischen Sprachen, op. cit. 65. 
perfectief aspect daarentegen is de oud-kaukasische structuur, die hierboven reeds kort is angeduid (92 v., 71 v.), nog bewaard gebleven. Het logisch subject staat in de ergatief, maar het object in de nominatief. De opvatting is nu dus min of meer passief-intransitief, d.w.z. hoogstens slechts half-dynamisch. Is c'er-s c'eril-sa ,er schreiben-er einen-Brief" = er schreibt einen Brief; maar iman da-c'er-a c'eril-i „durch-ihn schreiben ein-Brief” = er schreibt einen Brief.

Dat ook in een taal als het grieks soms de ene verbale vorm een transitieve betekenis kan hebben, maar een andere, die daaraan schijnbaar onmiddellijk verwant is, een intransitieve, is algemeen bekend. Zo b.v. van $\varphi \alpha i v \omega$,tonen” resp. $\pi \dot{\varepsilon} \varphi \alpha \gamma \varkappa \alpha$,ik heb getoond" maar $\tau \varepsilon \dot{\varepsilon} \varphi \eta v \alpha$

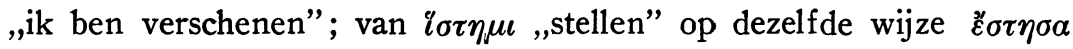
,ik stelde” maar है $\sigma \tau \eta \nu$, ,ik ging (bleef) staan”; $\pi \dot{\eta} \gamma \nu v \mu \iota$,,vast, hard maken" maar $\pi \eta^{\prime} \gamma v \boldsymbol{v} \mu \alpha$, vast worden" etc. Voor enkele andere dergelijke tegenstellingen in engelse dialecten, het creools van Mauritius etc. zie men nog O. Jespersen, The philosophy of grammar 158, noot 2 .

c. Misschien nog meer sprekend is de omgrenzing van de objectskategorie in kuschitische talen als het kafa en het afar ${ }^{133}$ ). Hier beschikken n.l. alleen de pronomina over eigen objectsvormen, bij de nomina worden nominatief en accusatief niet onderscheiden. Hoe nu de pronomina in dergelijke talen practisch enkel als persoonsaanduidingen gebruikt worden, hebben we reeds gezien. Het verschil komt dus hierop neer, dat men in zulke gevallen alleen bij de. hominiene kategorie een object kan hebben. Inderdaad maakt het ook een groot verschil uit, of een handeling een mens, een partner dus van gelijke structuur, treft, of wel b.v. een levenloos voorwerp. De situatie heeft in het eerste geval veel meer kleur en tekening, agens en patiens komen beiden veel scherper uit. Bij minder gewaardeerde wezens blijft de slotphase der actie onaanschouwelijk. Afar anu, ,io" maar $k \bar{e} a b b a$, $y(<y i)$ obbāy ,ascoltami, o padre”; atu ,tu”; ussik ,egli” maar kaya: ke atu iya? ya'leha'n iya'n ,domandarono a lui : chi sei tu?".

Ook in een aantal dravidatalen is de objectskategorie uitdrukkelijk tot enkele kategorieën van hoger geplaatste wezens beperkt. In het

133) L. Reinisch, Die Afar-Sprache I, SBAWW Bd. 111 (1885); G. Colizza, Lingua 'afar nel Nord-est dell' Africa, Vienna 1887; L. Reinisch, Die KafaSprache in NO Afrika I, SBAWW 116 (1888); C. Meinhof, Die Sprachen der Hamiten, Hamburg 1912; 119, 154; J. Wils, Das kuschitische Kasussystem, op. cit. $318 \mathrm{vv.}$ 
tamil en het malayalam wordt b.v. het accusatiefsuffix slechts zelden toegevoegd aan neutra, maar bij de woorden voor met rede begaafde wezens is het gebruik verplicht. In het telugu en andere meer naar het noorden gelegen dialecten keert dezelfde distinctie terug, maar nu tussen de animata en de inanimata ${ }^{\mathbf{1 3 4}}$ ).

In het australische wiraturai loopt de deellijn tussen de hominiene en de non-hominiene kategorie ${ }^{135}$ ). Eveneens in het singhalees, maar de namen van de levende wezens gaan hier, althans in het meervoud, gewoonlijk met de pronomina mee ${ }^{136}$ ). Ball-ō „Hünde (nom.)”; ball-an ,id. (acc.)".

Het verschil tussen een „direct” en een ,indirect” object is in dit verband zeker niet principiëel, zoals Trombetti reeds zeer terecht heeft opgemerkt ${ }^{137}$ ). Verschillende talen kennen daarom ook slechts één „objectief”, die zowel voor de accusatief als voor de datief dienst doet (georgisch, tschuwassisch, brahui, gondi, dravidische volksdialecten als korava, kaikadi, burgandi enz.). Het enige wat men in het algemeen kan zeggen, is dat de plastiek der verbale actie méér spreekt in een taal met een ,accusatief” en een "datief” naast en tegenover elkaar, dan in een taal met een verder niet gedifferentiëerde „objectief”, zoals de zoëven genoemde. Waar de tegenstelling tussen een datief en een accusatief bestaat, duidt de eerste vorm gewoonlijk eerder op een zijdelingse betrokkenheid bij de handeling, maar de accusatief op het direct daardoor ,getroffen” worden.

\section{De syntactische positie van het object.}

Juist zoals het subject een bijzondere syntactische positie in de zin inneemt, zo is dit ook - mutatis mutandis - met het object het geval. Ook het object wordt pas wat het is, wanneer men dit ziet tegen de

134) R. Caldwell, A comparative grammar of the dravidian or south-indian family of languages ${ }^{3}$, London 1913, 270 vv.; 359 vv.; A. H. Arden, A progressive grammar of the Telugu language, Madras 1873; J. Vinson, Manuel de la langue tamoule, Paris 1903, 70 vv.

135) Fr. Müller, Grundrisz der Sprachwissenschaft 2, 1, 18 vv.

136) Fr. Müller, Grundrisz der Sprachwissenschaft 3, 1, 136 vv.

137) A. Trombetti, Elementi di glottologia 266; Aage Hansen, On the so-called Indirect Object in Danish; Travaux du Cercle Linguistique de Copenhague 5 (1949), 198. 
achtergrond van de totale verbale structuur. Dat het object speciale morphologische kenmerken gaat vertonen, zonder dat tezelfdertijd ook het werkwoord als zodanig van structuur verandert, is ondenkbaar. Dit neemt echter niet weg, dat ook de ontwikkeling van het object weer een eigen rythme vertoont. We hebben dit ook reeds bij het subject gezien.

a. Zo vindt men vooreerst weer een aantal talen, waarin wel reeds het bestaan van de bijzondere nauwe verbinding met het praedicaat tot uitdrukking komt, maar nog niet de speciale aard daarvan, d.w.z. de direct op het object gerichte dynamiek. De opvatting, die vooral bij pronominale objecten naar voren komt, is nog min of meer statisch. De verhouding tot het praedicaat wordt juist zo gevoeld als die van een nomen rectum tot zijn regens. Men zou hier daarom van een ,genitiefobject” (genitivische objectsbepaling) of een „possessief” object kunnen spreken. Juist zo hebben we hierboven in de berbertalen en elders (94 vv.) reeds een ,genitiefsubject” (genitivische subjectsbepaling) ontmoet (status annexus).

Een eerste, bijzonder mooi voorbeeld van een dergelijk genitivische objectsbepaling heeft men in een aantal noord-amerikaanse talen (tsimshian, tlingit, haida, chinook, chimariko, maidu, yuki, pomo, muskogeis, siouxtalen als dakota enz.), waar C. C. Uhlenbeck reeds „het passief karakter" van het werkwoord heeft vastgesteld ${ }^{\mathbf{1 3 8}}$ ). Men dient bij de verbale affixen in deze talen telkens scherp tussen twee rijen tekens te onderscheiden. De ,energetische” tekens komen enkel voor als subjectsindex bij de transitiva. De tekens die daar tegenover staan, kunnen in niet minder dan drie verschillende functies voorkomen. $\mathrm{Zij}$ treden niet alleen als objectsindex bij de transitiva en tegelijk als subjectsteken bij de intransitiva op (deze combinatie is vrij gewoon in de talenwereld), maar tegelijkertijd ook bij het nomen als index voor de inalienabile possessie. De tweede rij is dus zowel ,inert" als ,inalienabel”. Er zijn in deze talen ook wel aparte alienabile affixen bij het nomen, die in vorm van de inalienabile afwijken, maar deze doen nooit bij het verbum dienst als objectselement. Juist zoals men b.v. in het tsimhian heeft $m$-zea'yin- $u$,jij hebt-gevonden mij”, zo luidt het hier

138) C. C. Uhlenbeck, Het passieve karakter van het verbum transitivum of het verbum actionis in talen van Noord-Amerika, VAWA 5e reeks, deel 2, A'dam 1916, 195 vv.; - , Het identificeerend karakter der possessieve flexie in talen van Noord-Amerika, VAWA 5e reeks, deel 2, A'dam 1917, 364 vv. 
ook $b a n-u$,mijn buik"; $n d z a^{\prime} k d-\varepsilon n$,ik heb-gedood jou” maar eveneens $t s ! a^{\prime} g \gamma-\varepsilon n$, jouw neus" enz.

Men ziet, op welk een merkwaardige wijze zich hier het verloop der handeling in de taal reflecteert. Het initiale moment, het stellen daarvan door de agens, wordt blijkbaar in dynamisch-dramatische zin doorleefd. Daarom gebruikt het werkwoord in dit geval speciale „energetische" tekens. Zo aanschouwelijk is de dynamiek echter aan de andere kant niet, dat deze ook nog de slotphase omvat. Halfweg de structuur treedt a.h.w. een zekere vervlakking in. De handeling geldt niet ten volle als ,centrifugaal”. En daarom staat het object hier ook genoemd als volkomen statisch en als geheel blijvend binnen de eigen onvervreemdbare sfeer: ,inert” en ,inalienabel”. Was de ontleding verder gegaan, was het werkwoord in deze talen van het ,actieve" type geweest, dan zou het object zeker ook wel als "getroffen" door de handeling, als „,passief” zijn voorgesteld. En er zou dan een accusatief-object zijn gevormd. Zou men daarom b.v. constructies als de bovenstaande uit het tsimshian althans enigszins naar hun eigen aard willen vertalen, dan zou men kunnen zeggen $m$-ra'yim- $u$,vanwege-jou het-gevondenworden-daar van-mij” = jij hebt mij gevonden; $n d z a^{\prime} k d-\varepsilon n$,door-mij dat-doden-daar van-jou" = ik heb jou gedood.

Andere bekende voorbeelden, waarin het verbale objectsteken regelmatig, of althans bijna regelmatig, in vorm samenvalt met het possessieve element, heeft men nog in de semitische talen. Arabisch daraba-hu „,er hat ihn geschlagen" maar ook kitâbu-hu ,sein Buch"; darabtu-ka ,,ich habe dich geschlagen" maar ook kitâbu-ka ,dein Buch”. Ook de objectieve vormen, die in een aantal fins-ugrische talen voorkomen, en waarover hierboven reeds in ander verband gesproken is (107), zijn volgens Szinnyei van nominaal-possessieve oorsprong ${ }^{139}$ ). Naast vormen als hongaars varo- $m$, ,ich erwarte ihn”; kère-d „du bittest ihn” staan b.v. constructies als ka'ro-m ,mein Arm"; vēre-d „dein Blut”.

Hoe ook de pronominale objectsvormen van de indo-europese talen, soms nauwer verwant zijn met de corresponderende possessieve tekens dan met hun eigen nominativi, weet ieder. Lat. me: me-us, maar ego; gri. $(\vec{\varepsilon}) \mu \dot{\varepsilon}: \vec{\varepsilon} \mu \delta \delta_{s}$ maar $\dot{\varepsilon} \gamma \dot{\omega}$ enz. In het bretons worden ook thans nog de possessiva regelmatig als direct object van de personalia gebruikt. Ook in sommige nederlandse dialecten vallen de vormen van deze beide

139) J. Szinnyei, Finnisch-ugrische Sprachwissenschaft, Berlin 1922, 131 vv. 
rijen herhaaldelijk samen. Nijmegen: Moeder, Kees hèt mien gasloaga! Ik sal jouw nog wellas kriegə, jöngske! Volkstaal: Heb je voor mijn ook wat? Ja, ik zal joure aan zien kommə!

De voorbeelden van nominale genitivische objectsbepalingen schijnen veel minder frequent te zijn dan de pronominale. Men vindt dit type echter toch weer in sommige semitische talen, in het jenissei-dialect van het samojeeds ${ }^{140}$ ); verder ook in bepaalde gevallen bij de slavische talen $\left.{ }^{141}\right)$. Eveneens in sommige nederlandse en duitse dialecten, vooral bij de persoonsnamen en namen van animata. Pools syn- $a$,den Sohn, des Sohnes"; Bommelerwaard Ik hè oomes gezien; Oudenbosch Wilde gij Mina's eventjes roepen? enz.

b. Bijzonder interessant in dit verband zijn nog enkele west-europese talen, omdat men hier twee typen van object tegenover elkander vindt: een genitivische objectsbepaling en een definiet, accusativisch object, dat van het hierboven onder a. beschreven type is (106). De objectsbepaling wordt nu in de grammatica gewoonlijk als „partitief” voorgesteld, omdat het gebruik ervan speciaal bij nomina quantitatis verplicht is. De overige regels leren echter, dat men beter in het algemeen van een ,indefiniet” of eigenlijk een ,half-definiet” object kan spreken.

Goed beschreven is de ontwikkeling in het frans ${ }^{142}$ ). De constructie met het partitieve artikel $d u(<d e l e)$, resp. de la komt reeds op in het oud-frans, maar het duurt tot de zeventiende eeuw vóór deze geheel en al als normaal wordt aanvaard. Later gaat de uitbreiding van het gebruik zéér ver, en het "partitieve" idee gaat daarbij steeds meer verloren. Trop a perdu del sanc. Roland 2229; manger du pain, de la viande; montrer de l'impatience; cette femme a du mérite. Moderne taal: un malade fait de la typhoïde; les automobilistes font du quatrevingts a l'heure etc. Maar natuurlijk in de „bepaalde" gevallen manger un pain etc.

Ook in het duits vindt men dergelijke genitivische objectsbepalingen met vage betekenis. Volgens H. Paul zijn ze speciaal thuis in de acht-

140) Fr. Müller, Grundrisz der Sprachwissenschaft, 2, 2, 164 vv.

141) A. Meillet, Recherches sur l'emploi du génitif-accusatif en vieux-slave, Paris 1897; Vgl. ook G. Royen, De jongere veranderingen van het indogermaansche nominale drieklassensysteem, 's Bosch 1926, 95 vv.

142) F. Brunot, La pensée et la langue ${ }^{3}$, Paris 1936, 110 v.; K. Sneyders de Vogel, Syntaxe historique du français 14 v., 287 v.; F. Brunot et Ch. Bruneau, Précis de grammaire historique de lạ langue française, 264 v.; 310. 
tiende eeuw, later neemt het gebruik weer in frequentie af ${ }^{143}$ ). Haben Sie schon von unsern neumodischen Handschuhen gesehen (Bode)? Wo ihr von unsern zerstreuten Knechten findt (Goethe). Ich wönschte du könntest auch von seinen Zeichnungen sehen (Schiller). Schicken Sie nur doch von dem Prinzessinwaschwasser (Iffland).

Iets meer ingewikkeld zijn de verhoudingen in het fins, omdat de spreker hier niet minder dan drie objectstypen tot zijn beschikking heeft. Het meest gewichtig voor ons doel is de tegenstelling tussen het z.g. ,partiële” object, dat door een vorm op $-a(\ddot{a})$, - $t a(t \ddot{a})$ wordt weergegeven, en het "totale" object, dat door een dubbel stel accusativi wordt aangeduid. Dat de vorm op $-a(-t a)$ in werkelijkheid niets met „delen” of „,verdelen” te maken heeft, evenmin als dat met de corresponderende franse en duitse constructies het geval is, is reeds door Fr. Müller vermoed ${ }^{144}$ ). Men staat hier in de grond voor juist dezelfde algemene casus indefinitus, die ook op allerlei andere punten in de uralische taalgeschiedenis zulk een voorname rol speelt. Een nadere analyse van de verschillende gebruikswijzen is beproefd bij Wils, De nominale klassificatie in de afrikaanse negertalen 173. Ostan kilon kahvi-a "Ich kaufe ein Kilo Kaffee”. Tuolla on kaksi kirja-a (maar $y k s i$ kirja) „Dort liegen (liegt) zwei Bücher (ein Buch)”.

\section{De waarderingsfactor.}

Hoe nauw het parallellisme tussen de subjects- en de objectskategorie ook moge zijn, op één punt blijft hier toch steeds een aanmerkelijk onderscheid: dat van de waardering. Het subject wijst op de agens d.w.z. het natuurlijk centrum van de gehele handelingservaring, de krachtige figuur die het bestaande evenwicht in de wereldorde verbreekt en door een ander vervangt. De waardering en de graad van aandacht zijn hier hoog. De houding van het object is daartegenover altijd min of meer passief en secundair. $\mathrm{Er}$ is hier daarom ook minder waardering en minder aandacht. Schuchardt schrijft: ,Jedes Object ist ein in den Schatten gerücktes Subject". Men kan van deze opvatting denken wat men wil (we zullen haar hierachter principiëel bestrijden), de heersende waarderingsverhouding tussen de beide typen van kategorieën is hier in ieder geval toch goed getroffen.

143) H. Paul, Deutsche Grammatik III, 346-370.

144) Fr. Müller, Grundrisz der Sprachwissenschaft 2, 2, 202 v.

Verh. dl. XII. 
Aan dit lagere waarderingsniveau is het zeker ook te wijten, dat de objectskategorie in het algemeen een veel minder scherpe en strakke structuur vertoont dan de subjectskategorie. De samenstellende componenten komen in beide gevallen stuk voor stuk nauwkeurig met elkander overeen, maar het verband daartussen is, zoals ons onderzoek duidelijk geleerd heeft, bij het object veel vager en losser. Het aantal mogelijkheden en variaties is aanmerkelijk groter. Historisch en comparatief gezien, verloopt ook de ontwikkeling van het object in het algemeen veel trager dan die van het subject. Zelfs waar de structurele voorwaarden voor het ontstaan reeds ten volle zijn vervuld, komt de verwachte kategorie in werkelijkheid nog niet, of hoogstens slechts zeer vaag, voor de dag. Speciaal bij de studie van enige afrikaanse taalgroepen is dit reeds gebleken ${ }^{\mathbf{1 4 5}}$ ). Ook op gevallen als de reeds besproken noord-amerikaanse talen mag hier zeker worden gewezen. Ook hier is het heel of half passieve object immers aanmerkelijk in ontwikkeling achter bij het actieve, puur-dynamische subject. Moeilijkheden leveren al dergelijke feiten niet op, en we behoeven er daarom niet lang bij stil te staan.

Alleen is het misschien nuttig er nog kort op te wijzen, dat ook op dit punt de gegevens uit de westerse talen weer die van de z.g. ,primitieve" volkeren ten volle bevestigen. Ook in onze contemporaine cultuurtalen bestaat er nog een vrij nauw verband tussen de subjectskategorie en de hogere klassen enerzijds tegenover de objectskategorie en de lagere klassen anderzijds.

Een voorbeeld daarvan levert het casussysteem der romaanse talen ${ }^{146}$ ). Verreweg de meeste franse, italiaanse, etc. substantiefvormen zijn, naar men weet, afgeleid van de vulgair-latijnse obliquus, die morphologisch aan de latijnse accusatief beantwoordt. Fra. mois < mensem; raison < rationem; amour < amorem; of ra. espos, ital. sposo, spa. esposo < sponsum etc. Juist bij een aantal persoonsnamen is de moderne vorm nu echter van de (vulgair)-latijnse nominatief afgeleid. De weg daartussen moet in dit geval dus wel bijzonder goed gebaand zijn geweest, anders was de ontwikkeling ook hier wel volgens het gewone schema verlopen. De persoonsnamen moeten van nature als

145) J. Wils, Die Entwicklung des kuschitischen Kasussystems, op. cit. 318 vv.

146) G. Royen, De jongere veranderingen van het indogermaansche nominale drie-klassensysteem, 's Bosch 1926, 127-131; 119, 133 vv. 
min of meer dynamisch-actief, d.w.z. volgens het geldende taalstelsel als nominativisch, zijn gevoeld. De lager gewaardeerde zaaknamen daarentegen denkt men zich eerder in objectsfunctie. Van nominativische oorsprong zijn b.v. frans soeur, prêtre, chantre, maire, peintre, sire; roemeens frate ,frère”; impărat „empereur”; jude „juge”; spaans Dios, portugees Deos; verder eigennamen als fra. Louis, Charles, Jacques, Pierre; ital. Giovanni; spa. port. Carlos etc.

Omgekeerd kunnen de namen van personen in bepaalde romaanse talen en dialecten niet als direct object voorkomen. Blijkbaar zijn hier juist dezelfde waarderingsfactoren geldend geweest als hierboven. Alleen werken ze nu negatief en afsluitend. Personen staan te hoog om door de verbale actie ,getroffen" te kunnen worden. Ze worden nu enkel als daarbij „geïnteresseerd” of ,betrokken” voorgesteld. En een praepositionele bepaling vervangt de naam, die anders direct object geweest zou zijn. Spaans yo veo al hombre; los romanos conquistaron a España; siciliaans L'aviti vistu a me frati? roemeens chiama pe Petru. In de germaanse talen komen analoge feiten voor. Zo stammen hier van de nominatief namen van hooggewaardeerde wezens als duits $A$ hne, Erbe, Bote, Drache, Falke; zweeds gubbe „grijsaard”; granne „,buurman, buurvrouw”; bonde „boer”; spjuver, luver "leperd” enz. Maar van de casus obliquus komen vormen als duits Balken, Ballen, Bogen, Brunnen enz. Voorbeelden van een personaal praepositioneel object heeft men in Zuid-Afrikaans: ek sien (vir) hom maar ons slag die os enz.

\section{De accusatief als de casus der eerste verbale adstructie.}

We hebben hierboven van ,het grote uur" der subjectskategorie gesproken, en bedoelden daarmee de periode waarin al de functionele componenten daarvan in actie komen en allerinnigst gaan samenwerken. De subjectsnaamval, nu gewoonlijk als ,nominatief” aangeduid door de grammatica, wordt daarmede tot de basis van het gehele casusstelsel. Wil men de beeldspraak doorzetten en ook voor de objectskategorie op iets dergelijks wijzen, dan zou men alleen aan die talen kunnen denken, waarin het transitieve constructietype, het enige structurele klimaat dus waarin het object van nature thuis is en waarin zich dit tot een zelfstandige ,accusatief" kan ontwikkelen, secundair ook over alle andere verbale verbindingstypen is uitgebreid. Het wordt nu alles 
„,nominatief” en ,accusatief” wat de klok slaat. En zoals iedere subjectsaanduiding hier een "nominatief" moet zijn, zo wordt elke nauw verbonden verbale adstructie in deze talen ook een ,accusatief”. Naar werkelijke aanschouwelijkheid der dynamiek wordt daarbij niet meer gevraagd. Geen enkele grens is meer veilig voor de invasie der nieuwe kategorieën. Intransitiva, copulatieve verbindingen, - al dergelijke typen worden volgens hetzelfde formele schema behandeld. Een langere zin zonder één of meer accusativische vormen is bijna niet denkbaar.

Hoe weinig redelijk deze ontwikkeling is, behoeft geen betoog. De natuurlijke basis voor de kategorie ontbreekt vrijwel geheel. Het nieuw gevormde type ,accusatief" dreigt een pure vormkategorie te worden. En het spook der totale verstarring is hier zeker nog meer nabij dan in het geval van de ,nominatief”. Het ,grote uur” is dus wel duur gekocht.

Het beste voorbeeld, dat men zich wensen kan, van een dergelijke, reeds half verstarde accusatief vindt men in de oudere indogermaanse en semitische talen. Met een zeldzame zin voor consequentie zijn bijna alle verbale (en zelfs ook vele nominale) verbindingstypen hier binnen de oppositie ,nominatief” : ,accusatief” gedrongen. Een andere mogelijkheid wordt vrijwel niet opengelaten. Elke gedachtenstroming, van welke aard ook, wordt hier als centrifugaal vanuit het subject op een bepaald ,object” gericht, opgevat. Zo staat hier niet alleen het directe object van een verbum transitivum in de accusatief, maar b.v. bij de intransitieve verba van beweging ook de richtingsaanduiding; in de semitische talen zelfs ook het praedicaatsnomen in een constructie met

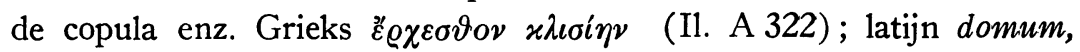
Romam ire; arabisch kânat fâtimatu 'bnata (4) 'lmaliki „Fatime war die Tochter der Königs"; fra. c'est lui; eng. it was him. Vgl. ook uitroepen als lat. heu, me miserum! o di boni, rem perditam! Ook adverbale bepalingen van allerlei aard staan in dergelijke talen regelmatig in de accusatief. Skr. saptádaša pravyādhān prá vidhyati „er schieszt 17

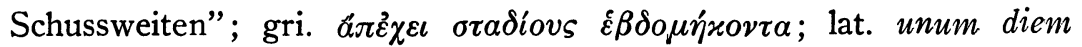
vivunt; Troia decem annos oppugnata est; gri. ( $\tau o ́)$ ev̉oos ,in breedte”; ( $\tau o ́) \beta a ́ v o s$,,in diepte” enz. Het meest karakteristiek is misschien echter de ,accusatief van het inwendig object" die, naar de naam al zegt, ook bij de intransitiva kan voorkomen, wanneer de handeling hier nl. met bijzondere heftigheid verloopt. De spreker objectiveert nu tot op zekere hoogte zijn actie, juist tengevolge van de speciale dynamiek. 
Welnu, ook deze act die puur tot het persoonlijk psychische beperkt blijft, wordt in de indogermaanse en de semitische talen direct in centrifugale en dramatische zin opgevat. Er ontstaat een ,inwendig object" dat grammaticaal volkomen met een ,uitwendig object” op één en dezelfde lijn staat. Juist zoals b.v. in het latijn heeft fossam fodere;

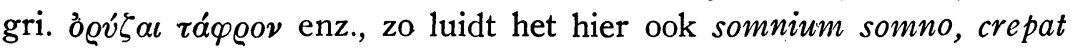

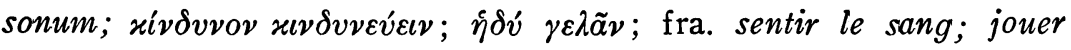
un feu d'enfer (maar vivre d'une vie nouvelle; hgd. eines natürlichen Todes sterben). Zelfs komen constructies voor met de beide objects-

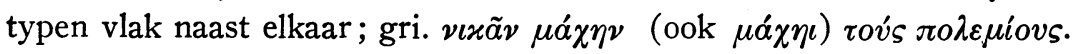

Ook in de moderne west-europese talen doen zich bij de datief en de accusatief de gevolgen der verbale verstarring danig voelen. De grenzen tussen de "transitiva” en de ,intransitiva” worden in de schoolse grammatica veelal enkel bepaald op grond van de logische analyse. De verkregen kenmerken gelden als ,lexicologisch”; d.w.z. men beschouwt ze als even vast en onveranderlijk als b.v. het flectietype waartoe het werkwoord behoort, of zoals men bij het nomen het woordgeslacht zou beschouwen. In werkelijkheid zijn hier echter slechts enkele kernen in het gebruik over gebleven, waarbij men met recht van een ,object” kan spreken. Daarbuiten is vooral de accusatief tot de rang van een pure vormkategorie afgedaald. Hier nog naar een vaste en reële grondslag voor het gebruik te vragen, ware ongerijmd. Zo is ook de datief in het engels en in het nederlands practisch bijna uitsluitend tot de namen van personen beperkt. Alleen in bijzondere gevallen vindt men ook vormen uit lagere waarderingsklassen in deze functie. He struck the table a heavy blow (Dickens); I never gave the existence of Captain Dobbin a single moment's consideration (Thackeray); nedl. Je moet dat hek eens een verfje geven.

Van een ,direct object” kan men in het algemeen alleen spreken, wanneer de verbale handeling bijzonder anschouwelijk is en als duidelijk centrifugaal gevoeld wordt. De subjects- en de objectskategorieën gaan ook in dit opzicht dus weer gelijk op. In veel gevallen wordt b.v. enkel de situatie als zodanig bedoeld. Er heeft geen verdere objectivering plaats. Hoe zou dan dus een werkelijk ,object" kunnen ontstaan? Als b.v. de vrouw des huizes thuiskomt en naar de dienstbode informeert, kan het antwoord luiden: She is making the beds; doing the rooms; making tea; fetching coal. Van enige bewuste dynamiek of een daardoor getroffen "object" valt hier geen spoor te bekennen. 
Constructies als: She is upstairs; in the kitchen; in the cellar zouden juist zoveel zeggen. Hgd. das Geschirr (Gefäsz) (auf) waschen; ein Spielchen machen; Bescheid, einen Zug tun (bij het drinken); eine Frage tun. Fra. faire une chambre, les lits; mettre fin à qc.; mettre son espérance dans qn.; mettre de tordre dans ses affaires; Nedl. En wanneer komen jullie $n u$ bij ons een keer een kopje thee halen, een kaartje leggen (tegen kennissen bij een ontmoeting)? In het engels wordt in dergelijke gevallen veelal de z.g. progressive form gebruikt, een constructiewijze dus die algemeen juist als toestandsbeschrijving bekend is. I was reading a book when he entered maar I read a book yesterday evening. In another year I shall probably be growing tea in Ceylon.

Speciaal lichaamsdelen dragen een te inalienabel karakter om als „object” bij de eigen handeling van de spreker te kunnen optreden. Fra. fermer les yeux (= sterven); fermer un oeil (= toegevend beoordelen); branler, hocher la tête; joindre les mains (= bidden); hgd. die Hände in den Schosz legen; festen Fusz fassen. In het engels vindt men daarom in dergelijke gevallen meestal ook een genitief ${ }^{\mathbf{1 4 7}}$ ). $\mathrm{He}$ saved my life, maar nedl. Hij redde mij het leven; Mrs. and Mr. Creakle were both wiping their eyes (Dickens). She waved her handkerchief in token of farewell, maar nedl. Zij wrifde met de (haar) zakdoek ten teken van afscheid. In speciale omstandigheden kan de ontleding natuurlijk gemakkelijk verder gaan.

Iets analoogs heeft men bij allerlei verba van gemoeds- en gevoelsreacties. De houding van het subject is nu min of meer passief. De samengestelde uitdrukkingen zijn practisch één geheel geworden. Hgd. Schmerzen (er)leiden, ausstehen; einem sein Leid klagen; seinen Kummer ausweinen; einem seine Not klagen; Klage (Beschwerde) über einen führen. Eng. To bestow much care upon something; to pay attention to; to set one's heart on. Nedl. zijn beklag doen; veel in zijn leven meegemaakt hebben enz. Zelfs bij sommige verba van zintuigelijke waarneming kan het onwillekeurig moment zozeer overwegen, dat men niet of nauwelijks van een object kan spreken. Hgd. einen gewahr, ansichtig werden; Wind (Luft) von etwas bekommen; fra. apercevoir $q c$.

147) H. Poutsma, A grammar of late modern english, Pt. I, Groningen 1904, 143, § 15 ; R. W. Zandvoort, A handbook of english grammar, Groningen 1945; $119, \S 334$. 
Hoe ten slotte ook het reflexieve pronomen sich, se etc. bij allerlei verba in de europese talen tot een puur vormwoord is geworden, weet ieder. Alleen de abstract-logische analyse, d.w.z. een extra-linguistisch moment, kan hier nog iets van „transitiviteit” en „object” ontdekken. De taal zelf weet daarvan verder niets. In een taal als het hongaars vallen de reflexiva zelfs in het geheel niet onder de kategorie der transitiva, maar onder die der intransitiva. Dit is wel zeer begrijpelijk. Fra. se rappeler; se rendre; se tromper; se mouvoir; se confesser; hgd. sich erinnern; sich fürchten; sich grämen; sich bewerben; sich unterstehen enz.

Omgekeerd kunnen echter ook niet alle intransitiva op één lijn gesteld worden. Er zijn ook gevallen waarin binnen de menselijke persoon kleinere of grotere spanningen optreden. Het intransitieve werkwoord verkrijgt daardoor een zekere dynamische nuance, en nadert tot op zekere hoogte de groep der transitiva. Verba als to sit; to lie; to rest kunnen b.v. zeker als intransitief tout court gelden. Initiale noties als to start; to put on speed; to put a spurt on etc., of aanduidingen van hevige uiterlijke of innerlijke bewegingen als to spring; to run; to race; to dive; to overcome (difficulties); to set about (one's work) etc. naderen echter ten dele reeds de structuur der transitiva. In het gri.

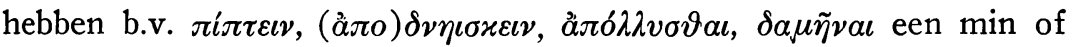
meer intransitief-passieve nuance, maar $x \tau \varepsilon i v \varepsilon \imath \nu$ is juist meer actief. $M \alpha \nu \vartheta \alpha \dot{\nu \varepsilon \varepsilon \nu}$ betekent , in zijn geest opnemen" (= leren) maar $\delta \iota \delta \alpha ́ \sigma \varkappa \varepsilon \iota \nu$ is ,duidelijk maken” (id.). Juist zo staan in het latijn b.v. ook perìre en perdere, vapulare en virgis caedere tegenover elkaar ${ }^{148}$ ).

De gewone manier in de indogermaanse talen om de immanente, intransitieve dynamiek te activeren bestaat, naar men weet, in de toevoeging van een richtingsprefix. De betekenis wordt daardoor meer ,punctueel" ${ }^{149}$ ). Hgd. lachen maar auslachen; laufen maar durchlaufen; gehen maar entgehen. In de literatuurtaal komt soms zelfs het gebruik van min of meer "lege” vormwoorden voor, wanneer men bij een intransitivum een bijzonder hoge graad van activiteit wil uitdrukken.

148) E. Schwyzer, Zum persönlichen Agens beim Passiv, besonders im Griechischen; Abh. Preusz. Akad. der Wiss. 1942; Phil. hist. K1. Nr. 10; 12 v. Vg1. ook E. Wistrand, Ueber das Passivum, Göteborgs Kungl. Vetenskaps- och Vitterhets-Samhälles Handlingar; Sjätte Följden, Ser. A. Bd. I. No. 1; 17.

149) K. Brugmann, Kurze vergleichende Grammatik der indogerm. Sprachen', 563 vv. 
Ich wollte, du lachtest eins mit (Klinger). Tot de gewone duitse spreektaal behoren zegswijzen als das Blaue vom Himmel herunter schwätzen; sich die Schreindsucht an den Hals ärgern ${ }^{150}$ ); nedl. een deuntje huilen; zich een bult lachen; zich een rotje werken op een repetitie (jongenstaal).

In verscheidene andere gevallen blijkt de slechts zwak actief-dynamische doorleving van de objectsverhouding hieruit, dat de verbale constructie nu niet omkeerbaar is in het passief. Het logisch aanwezige ,object" heeft dan practisch te weinig structurele relevantie om in het laatste geval als subject te kunnen optreden. Het transitief is activum tantum. Men vindt bij dit merkwaardige verschijnsel dezelfde verbale betekeniskategorieën terug als hierboven ${ }^{151}$ ).

In talen als het engels en het deens kan niet alleen het oude directe object uit de actieve constructie als passief subject gaan optreden, maar ook het ,indirecte object” en zelfs een gewone adverbale bepaling. Ook dit is zeker een gevolg van de verminderde anschouwelijkheid der verbale actie. Al de genoemde kategorieën zijn daardoor elkaar min of meer genaderd. Eng. Milton was given the post of latin secretary. The doctor was sent for; the bed had been slept in. De.Han blev tilkendt prisen ,ihm wurde der Preis zuerkannt” (actief: tilkende nogen (3) prisen); Han blev ikke taget notis af ,es wurde keine Notiz von ihm genommen" (tage notis af nogen). Zwe. Han avkläddes sina kläder (naast kläderna avkläddes honom) „,es wurde ihm die Kleider ausgezogen" (de avklädde honom (3) kläderna).

Heel frequent is tenslotte ook het geval, dat de ene taal met een object weergeeft hetgeen in de andere door een praepositionele constructie wordt uitgedrukt. Van betekenisverschil valt daarbij niets of vrijwel niets te merken. De verstarring van het object is hier dus vrijwel volkomen. Zo b.v. nedl. zich in de handen zerijven, maar hgd. sich die Hände reiben; eng. to rub one's hands; fra. se frotter les mains; it. stropicciarsi le mani. Fra. sentir le tabac, maar eng. to smell of drink;

150) H. Paul, Deutsche Grammatik III, 232; H. Delacroix, La pensée et la langue $311 \mathrm{v}$.

151) J. Wils, De oorsprong van het verbale $r$-passief in de indogermaansche talen, Med. Nedl. Akad. v. Wetensch., afd. Letterk. NR, deel 3, Nr. 11, A'dam 1940, 12 v.; H. Frei, La grammaire des fautes, Paris 1929, $221-225$ (,conversion”) ; Björn Carlberg, Subjektsvertauschung und Objektsvertauschung im Deutschen, Lund 1949. 
nedl. ruiken naar tabak; hgd. riechen nach etwas; it. sentire di qualche cosa. Fra. écouter un ami, les paroles de quelqu'un; it. ascoltar qualche cosa; ook lat. audire aliquem, auscultare alicui, maar eng. to listen to a person; nedl. luisteren naar iets; hgd. auf jemands Worte hören; auf einen hören; spa. escuchar á una persona, á una idea. Fra. commencer un ouvrage; hgd. eine Arbeit anfangen; it. iniziare, avviare un affare, maar eng. to begin ( $u p$ ) on something (naast to begin it); nedl. aan (met) zijn werk beginnen; Fra. cela crie vengeance; it. gridar vendetta; spa. clamar venganza, maar eng. to cry for vengeance; nedl. schreeuwen om wraak; hgd. schreien nach Rache.

\section{HOOFDSTUK XI.}

\section{De voornaamste syntactische verhoudingen.}

In de beide voorgaande hoofdstukken hebben we getracht, langs een enigszins andere weg dan totnutoe gevolgd werd, dieper in het vraagstuk van de verschillende flectietypen in te dringen. Wat heeft onze speurtocht ons nu tenslotte opgeleverd? Als geheel mogen we, naar het ons voorkomt, over het resultaat niet ontevreden zijn. Op zijn minst genomen, heeft het onderzoek van een groot aantal primitieve talen ons allerlei zaken àfgeleerd, die gewoonlijk voetstoots en zonder nader bewijs in de grammatica worden aangenomen, en die toch het zuivere begrip van de onderzochte kategorieën benadelen. Zo weten we b.v. thans dat een subject, om een geheel volwaardige vertegenwoordiger te zijn van zijn soort, volstrekt niet altijd in de nominatief behoort te staan. Een genitief, een datief, een ablatief, of ook een ergatief kunnen voor dit doel even goed voldoen. En een object kàn een accusatief zijn, maar met een vorm die formeel niet van een nominatief te onderscheiden valt, of met een genitief, is men voor deze kategorie volstrekt niet minder af. Alles hangt maar af van het structurele type waarop de betreffende taal gebouwd is, en dat daar de doorslag geeft.

Op de oude vragen moge aldus een ander licht zijn gevallen, anderzijds is het duidelijk dat men niet enkel bij dergelijke negatieve punten zal kunnen blijven staan. De bedoeling van het onderzoek kan niet zijn, 
te weten hoe het niet is maar hoe het wèl is. En na de ondernomen „reiniging” van de vroegere opvattingen, zullen we in de volgende hoofdstukken de bestudeerde kategorieën dus vooral van de positieve zijde, en constructief dienen te behandelen ${ }^{\mathbf{1 5 2}}$ ).

1. Daar is dan vooreerst de vraag naar het wezen van de subjectskategorie. Men mag daarin niet enkel de representant zien van de objectieve ,agens" bij de handeling, nòch van de corresponderende logische kategorie, en al evenmin van het vertrekpunt der gedachte zoals de psychologen ons gaarne plegen voor te houden. Men behoort van een zuiver taalkundige analyse uit te gaan. We hebben daarover reeds herhaaldelijk gesproken. Welnu, stelt men de zaken in dit perspectief, en houdt men rekening met deze restricties, dan valt de genoemde vraag o.i. niet moeilijk te beantwoorden. Wat o.i. taalkundig voor de subjectskategorie beslist, is dat door de verbinding daarvan met een praedicaat een zin ontstaat. Dit kenmerk is noodzakelijk maar ook voldoende. Aan meer gegevens is er geen behoefte. Niet het subject, op zichzelf beschouwd, vormt een zin; ook het praedicaat doet dit niet alleen, maar het subject en het praedicaat samen vormen onmiskenbaar wat men in de grammatica gewoon is een zin te noemen. Van geen enkele andere combinatie van zinsleden kan ditzelfde worden gezegd. Het subject en het praedicaat zijn, aldus beschouwd, allereerst correlatieve kategorieën.

Daarmede is de beschrijving echter nog niet voltooid. De functies van het subject en van het praedicaat bij het tot stand komen van de zinsverbinding zijn immers duidelijk niet geheel aan elkaar gelijk. De beide leden der constructie werken niet op volkomen dezelfde wijze aan de gevormde eenheid mede. Hoe is daarbij ieders taak? - Iedere zin kan men beschouwen als een zekere totaliteit, een zeker schema. Welnu, de kategorie die deze totaliteit voor de concrete taalervaring stelt, is onmiskenbaar het praedicaat. Het subject doet daartegenover niets anders dan deze totaliteit, dit schema, sluiten en voltooien. Een neder-

152) A. de Groot, Structural Linguistics and Syntactic Laws, Word 5 (1949), 1; A. Séchehaye, La méthode constructive en grammaire et son application; Cahiers Ferd. de Saussure 4 (1944), 23-25; C. E. Bazell, Syntactic relations and linguistic typology; Cahiers F. de Saussure 8 (1949), 5-20; L. Hjelmslev, La catégorie des cas. Etude de grammaire générale, Copenhague 1936-37; R. Jakobson, Beitrag zur allgemeinen Kasuslehre, TCLP 6 (1936), 240; H. Vogt, L'étude des systèmes de cas, Travaux du Cercle Linguistique de Copenhague 5 (1949), 112; H. C. Sørensen, Contribution à la discussion sur la théorie des cas, ibid. 134; J. Lotz, The semantic analysis of the nominal bases in Hungarian; ibid. 185. 
lands praedicaat als b.v. loopt is aanmerkelijk méér dan enkel de naam van een zekere handeling. Voor iedere taalpartner wordt daarmede tegelijkertijd ook een bepaald syntactisch veld geopend. Een deel daarvan kan men direct reeds overzien; maar daarnaast blijft ook nog open, wat Bühler met een fraaie term een „Leerstelle” heeft genoemd. De gebruikte taalvorm vraagt om voltooiïng. $\mathrm{Er}$ is een zekere spanning gewekt die naar bevrediging streeft. „Wie is het die loopt?”, zo wil ieder weten. En het antwoord wordt gegeven, de spanning verdwijnt door het noemen van het tweede lid der constructie, d.i. het subject. Vader loopt. Het kind loopt. Het subject en het praedicaat zijn dus, behalve correlatieve kategorieën ook contemporaine en elkander constituerende kategorieën. Deze beide functies roepen elkander a.h.w. op. Men zou de verbinding a.v. schematisch kunnen voorstellen:

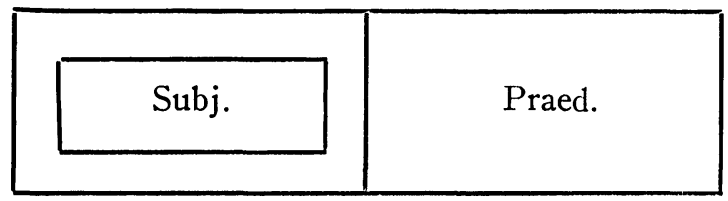

Men ziet, hoe de hier gegeven voorstelling van zaken op bepaalde punten vrij sterk van de gewone opvatting afwijkt. Vooreerst verliezen de beide behandelde kategorieën thans de zelfstandigheid die zij in de vroegere beschouwing bezaten. $Z_{\mathrm{ij}}$ zijn niet elk, in mechanisch-strakke zin, op een ander deel van de werkelijkheid betrokken. Enkel samen, en in onderlinge afhankelijkheid, duiden zij de werkelijkheid aan. In het noemen van de agens zit in beginsel ook de actie reeds in, juist zoals omgekeerd de actienaam onmiskenbaar naar de agens terugverwijst.

Verder kan men ook, naar onze mening, niet zeggen, zoals men wel vindt, dat het subject in de zinsconstructie een dominerende positie inneemt, en dat het praedicaat daarvan ,afhankelijk", of daaraan „ondergeschikt" is. Evenmin in de orde van de tijd kan men het subject primair achten, terwijl het praedicaat daaraan secundair zou worden. „,toegevoegd”. De schematische orde waarover het hier gaat, wordt door beide kategorieën samen geconstitueerd. Ieder lid werkt daaraan op eigen, zelfstandige en onverwisselbare wijze mee. Het karakter der verbinding is daarenboven in de grond abstract en immateriëel, en van een „vroeger” of een ,later” in de tijd kan daarbij verder niet worden 
gesproken. De totale constructie is er op een gegeven moment voor de taalervaring, of deze is er niet.

2. Bij het praedicaat spreekt het verschil tussen de oudere en de nieuwere opvatting nog meer dan bij het subject ${ }^{153}$ ). Ook hier meende men totnutoe met vrij eenvoudige noties te kunnen volstaan. Volgens de activisten bestond de taak van het praedicaat in het noemen van de handeling die plaats greep. Het subject gaf dan verder de agens daarvan aan. De logici hielden het praedicaat voor het sluitstuk van het oordeel dat door de zin werd uitgedrukt. Het praedicaat omvatte daarbij het ,nieuwe”, datgene wat er speciaal van het subject werd vermeld. De psychologen van hun kant zagen in het praedicaat enkel het sluitstuk van de zich ontwikkelende gedachte. De zinsconstructie werd daarmede pas voltooid.

Hoe zijn nu echter de werkelijke structurele verhoudingen? Hoe kan het praedicaat van strikt-taalkundig standpunt worden gedefiniëerd? Men dient hierbij uit te gaan, zo komt het ons voor, van het feit dat het praedicaat het zinslid, en wel het enige zinslid is, waartoe alle overige leden van de zin in betrekking staan. Men staat hier duidelijk voor een zeer centraal moment in de totale structuur.

Het valt niet moeilijk om dit laatste karakteristieke feit in te zien en te bewijzen. Over de verhouding van het subject tot het praedicaat is zoëven al gesproken. Ook het object staat echter tot het praedicaat in een geheel eigen relatie. En van de adverbale bepalingen van plaats, tijd, ,omstandigheid” en dgl. geldt, mutatis mutandis, hetzelfde. Voor de opbouw van de zin is het praedicaat m.a.w. het unificerende en centraliserende element waarin alle leden, zovele als die er zijn, elkander ontmoeten en hun binding ontvangen. De onderlinge verhoudingen worden hier bepaald en gerealiseerd. Van geen enkel ander zinsdeel kan ditzelfde op gelijke wijze worden gezegd. De door het praedicaat gestelde schematische structuur omvat dus blijkbaar ook niet enkel de „Leerstelle” voor het subject waarover hierboven reeds is gesproken. In elke zin zijn er bij het praedicaat evenveel „Leerstellen” als daar leden van de zin in worden aangetroffen. Ieder van de leden vult a.h.w. weer een daarvan in. Men kan het praedicaat, om hetzelfde

153) K. F. Sundén, The predicational categories in english. A category of predicational change in english. Uppsala 1916 (1918); -, Linguistic theory and the essence of the sentence. Göteborg 1941. 
nog eens anders te zeggen, dus ook, in tegenstelling met alle andere syntactische kategorieën, definiëren als een meer-dimensionale kategorie. Het aantal leden is daarbij in beginsel vrij; het kan onbeperkt toenemen, omdat ook de zin, althans in theorie, een onbeperkt aantal leden kan hebben.

Natuurlijk dient hieraan direct te worden toegevoegd, dat de betrekkingen tussen het praedicaat en de afzonderlijke leden van de zin telkens in karakter verschillen. Zo ziet ieder hier onmiddellijk het onderscheid tussen een directe en een indirecte band. Het subject, het object en de adverbale bepalingen hebben b.v. een directe verhouding tot het praedicaat. Worden deze zinsleden echter zelf weer in de vorm van een aparte syntactische constructie weergegeven, dan staan de ondergeschikte leden daarvan natuurlijk slechts in een indirect verband tot de hoogste ordening van de zinstructuur. Vader loopt in de tuin maar De vader (van Jan) loopt in de tuin (van zijn buurman).

De onbeperkte philosophische en psychologische beschouwing in de taalkunde heeft van het praedicaat een ,afgeleide” of een „toegevoegde” kategorie gemaakt. Naar men ziet, zijn de verhoudingen van strikttaalkundig standpunt geheel anders. Men staat hier voor niet minder dan het dominante, unificerende moment van de gehele zinstructuur.

3. En nu het object? Dat men ook hier voor een van de voornaamste leden van de zin staat, is duidelijk. Een dubbele afgrenzing is echter noodzakelijk. Vooreerst reikt de betekenis van het object blijkbaar niet zo ver als die van het subject. Men kan niet zeggen dat het object mede de zinsstructuur constitueert, zoals dit bij het subject wel het geval is. De verbinding van een object met een praedicaat zet enkel een zin voort, zoals die door de combinatie van een subject met een praedicaat reeds was gevormd. Syntactisch ligt de rang van het object dus een trap lager dan die van het subject. Anderzijds intussen is de verbinding van een praedicaat met een object aanmerkelijk hechter en meer dynamisch van aard dan die met een gewone adverbale bepaling. Syntactisch gesproken, staan de bepalingen op de laagste trap. Bij de objectskategorie is de integratie in de praedicaatsstructuur veel vollediger.

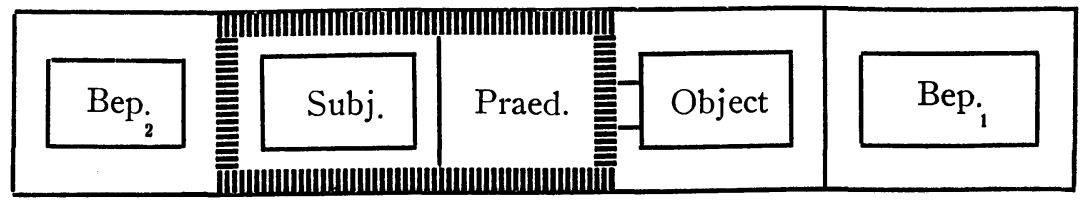


Voor de comparatie is hierbij de voornaamste conclusie, dat dus ook nu de logische analyse niet alleen kan beslissen. Uit het feit dat er „objectief” bij een bepaalde handeling een zeker object wordt getroffen, kan men nog volstrekt niet afleiden dat er in de corresponderende zin dus ook, taalkundig gesproken, een object aanwezig dient te wezen. De beslissing over deze vraag hangt alweer uitsluitend af van de geldende taalstructuur. En ook twee overigens nauw verwante talen kunnen daarbij gemakkelijk geheel andere wegen gaan.

4. Deze laatste opmerkingen leiden ook reeds de karakteristiek in van de subjects- en de objectsbepalingen die we nog te geven hebben. In allerlei typen en vormen hebben we in de niet-indo-europese talen dergelijke kategorieën ontmoet. Waarop berust nu precies het verschil tussen twee corresponderende typen, d.i. een subject en een subjectsbepaling, resp. een object en een objectsbepaling? Ook hier staat men naar onze indruk weer voor niets anders dan een verschil in vorm en graad van integratie ${ }^{154}$ ). Zowel bij het subject als bij de subjectsbepaling komt de verbinding met het praedicaat, en daarmede dus ook de zin als zodanig, effectief en de facto tot stand. Bij de bepaling echter blijven de beide componenten tot op zekere hoogte nog zelfstandig en onafhankelijk. Maar bij het subject overweegt geheel de totaliteit. Van elk der leden blijft hier niet meer over dan wat deze dominante allesomvattende structuur kan dienen. De zin is nu, naar verhouding, dus een veel meer gesloten systeem. Juist zo gaat ook het object a.h.w. geheel op in zijn band met het praedicaat. Bij de objectsbepaling dringt de geleding lang zo ver niet door.

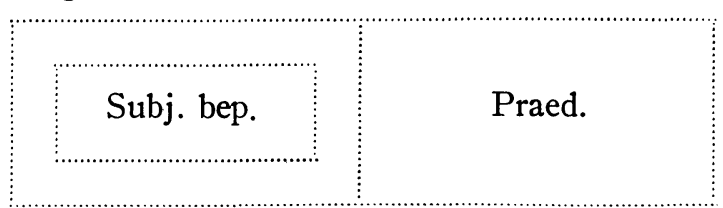

Men kan hieruit twee conclusies afleiden. De eerste is dat de subjectsbepaling en het subject (resp. de objectsbepaling en het object), telkens duidelijk tot dezelfde klasse behoren. Het beslissende feit is - het zij herhaald -, dat in beide gevallen het subject in de structuur van het praedicaat wordt opgenomen. Er komt dus steeds een zin tot stand.

154) C. E. Bazell, On the neutralization of syntactic oppositions; Travaux du Cercle Linguistique de Copenhague 5 (1949), 77; -, Syntactic relations and linguistic typology; Cahiers F. de Saussure 8 (1949), 5-20; -, The fundamental syntactic relations; Vilém Mathesius Memorial Lectures, III (1949), 3-17. 
Het subject, resp. het object, krijgt in de grammatica gewoonlijk alleen een enigszins aparte plaats op grond van een zekere - eenzijdige traditie. Hier staat men n.l. voor het type dat ook in de klassieke talen voorkomt, en dat aldus ook het gewone voorbeeld geworden is waarmede men ook voor de moderne talen nog rekening houdt. In de grond echter bestaat hier geen essentiëel maar enkel een gradueel verschil met de subjects-, resp. de objectsbepalingen.

Op de tweede plaats blijkt uit de gegeven beschrijving direct, dat het onderscheid in graad en vorm van integratie hier niet alleen betrekking heeft op de subjectskategorie, maar dat ook de andere leden van de zin die daarmede tot een en dezelfde constructie zijn verenigd, daarin delen. Het totale plan van de zin is hier m.a.w. in het spel. Bij ieder type van subject hoort ook een eigen type van praedicaat; of omgekeerd gezegd, bij ieder type van flectie hoort ook een eigen type van subject. Volkomen exact de verschillen tussen de flectietypen aanduiden aan de hand van nederlandse voorbeelden is uiteraard niet mogelijk. Men kan echter wel een aantal benaderende voorbeelden geven. Zo kan de realiteit van een constatering als "Vader loopt" ook worden weergegeven door een constructie met een subjectsbepaling: Bij-vader daarloopt-het. Men kan zich voorstellen dat er in het laatste geval in bepaalde talen b.v. geen persoonsflectie optreedt. Het werkwoord blijft ,,vormeloos", omdat er ook inderdaad geen nauwere syntactische verbinding van het subject met het praedicaat optreedt. Men staat ongeveer voor een impersonale. Bij een transitivum kan op dezelfde wijze ook gemakkelijk een objectsbepaling ontstaan. Vanwege (door, bij)-die-man doodt-het-daar naar (bij)-die-vogel met-een-steen $=$ Die man doodt de vogel met een steen. De aanduiding van het (logische) object vertoont in dit laatste geval geen enkel speciaal kenmerk waardoor dit op principiële wijze van een andere adverbale bepaling zou verschillen. Er is, in de structuur van een bepaalde taalstijl gezien, dus ook geen enkele reden waarom deze kategorie hier een bijzonder morphologisch teken zou vertonen.

Tot zover - in positieve zin - over de syntactische verhoudingen in het algemeen. Rest ons verder nog slechts deze zelfde princiepen nu ook nog toe te passen op de beide voornaamste flectietypen waarmede het onderzoek ons in aanraking heeft gebracht, d.w.z. de ,possessieve” flectie en het z.g. „passieve” werkwoord. We zullen daaraan telkens een apart hoofdstuk wijden. 


\section{HOOFDSTUK XII.}

\section{De possessieve flectie.}

Welke kenmerken gelden nu voor de z.g. „,possessieve flectie”? Hoe kan men een dergelijk vormtype, dat zo gewichtig is voor de indonesische comparatie, nu analyseren, steunend op de in de voorgaande hoofdstukken ontwikkelde princiepen ? ${ }^{\mathbf{1 5 5}}$ ).

Nemen we allereerst een paar evidente voorbeelden, en wel uit het indonesisch zelf. Zo b.v. tontemboan:

$u m a-k u$,mijn akker”

uma-mu, ,jouw akker" sisile $\dot{n}-k u$, ,ik vertel, door mij wordt verteld"

sisilen-u ( $<$ sisilen-mu) ,jij vertelt, door jou wordt verteld" ${ }^{156}$ ).

Of met enig verschil van plaatsing der tekens in het bimanees :

ana-ku ,mijn kind”

ana-mu ,jouw kind"

ana-na ,zijn kind”

ana-ta ,ons (incl.) kind” enz.
$K u$-lao(-ra enz.) ,ik ga”,
$m u-l a o(-r a$ enz.) ,jij gaat”
$n a-l a o(-r a$ enz.) „hij gaat”
ta-lao(-ra enz.) „wij gaan” enz. $\left.{ }^{\mathbf{1 5 7}}\right)$

Er zijn drie opvallende punten in paradigmata als deze. Op twee daarvan heeft niemand minder dan $W$. von Humboldt reeds gewezen (65 vv.). Vooreerst naderen de kategorieën van het nomen en het verbum elkaar blijkbaar véél meer in de talen met possessieve flectie, zo zegt deze grote geleerde, dan b.v. in de westerse talen gebruikelijk is. Soms is men zelfs geneigd te denken, dat daartussen in het geheel géén onderscheid meer bestaat. Verder kent men hier in ieder geval ook niet het onderscheid tussen de personalia en de possessiva, die elders veelal elk over een eigen rij van vormen beschikken. En tenslotte, zo kan men hieraan nog toevoegen, staat men in dergelijke gevallen ook duidelijk voor een genitivische subjectsbepaling. Wat is nu de oorzaak van deze afwijkingen? Hoe deze zijn ontstaan, en waarom komen deze in zovele talen van de wereld stééds alle drie naast elkander voor? Moet de knoop hier geheel naar de nominale zijde worden door-

155) J. Wils, De z.g. „possessieve flectie”; Bingkisan Budi. Een bundel opstellen aan Dr. Philippus Samuel van Ronkel aangeboden (1950), 310-321 (met literatuur).

158) N. Adriani en M. L. Adriani, geb. Gunning, Hoofdstukken uit de Spraakkunst van het Tontemboansch; 's Hage 1908, 245 vv.

157) J. Jonker, Bimaneesche Spraakkunst, VBG 48 (1896) derde stuk, 284. 
gehakt, zoals Schleicher, Fr. Müller, Trombetti e.a. meenden? Is er dus iets minderwaardigs gelegen in de possessieve flectie, en heeft men het recht deze op grond daarvan tenslotte niet als een ware „,verbale flectie" te beschouwen? Of blijft er hier nog een andere weg open?

$\mathrm{Na}$ het vorige hoofdstuk spreekt het antwoord op de gestelde vragen, naar het ons voorkomt, als vanzelf. Voor enig depreciërend oordeel over de possessieve flectie bestaat o.i. geen enkele grond. Integendeel, we staan hier voor een uitingsvorm die in een bepaalde phase van de geestes- en de taalontwikkeling als de volkomen natuurlijke en normale moet worden beschouwd. De beschreven karaktertrekken horen allerinnigst bijeen. En voor een weigering van het stigma: „werkwoord” of „flectie” bestaat geen reden.

De vereiste argumentatie kan kort zijn. 1. Wat allereerst de kwestie der woordsoorten betreft, nergens staat geschreven dat alle talen der wereld dezelfde woordkategorieën dienen te onderscheiden; en nog veel minder, dat de grenzen daartussen overal steeds even scherp en markant dienen te $z$ ijn ${ }^{158}$ ). Ook in dit opzicht heeft iedere denkvorm weer zijn eigen behoefte. In de oudere westerse talen gelden tot op zekere hoogte de aristotelische kategorieën, die de griekse wijsgeer daarom ook niet bij toeval voor een deel als uit zijn eigen moedertaal

158) F. Müller, Grundrisz der Sprachwissenschaft I, 1, 111-128; H. SteinthalF. Misteli, Charakteristik der hauptsächlichsten Typen des Sprachbaues, Berlin 1893, 2 vv.; H. Paul, Prinzipien der Sprachgeschichte ${ }^{5}$, Halle 1920; 352-372; W. Wundt, Die Sprache 4 , II, 73 v., 136 v., 139 vv., 282 vv.; J. Wackernagel, Vorlesungen über Syntax I, Basel 1920, 70 vv.; J. Vendryes, Le langage, Paris 1921 ; O. Jespersen, Philosophy of grammar, London 1924, 58-95; -, The essentials of english grammar 73; A. Séchehaye, Essai sur la structure logique de la phrase, Paris 1926, 91-119; E. Hermann, Die Wortarten, Nachrichten v. d. Ges. der Wiss., Göttingen, Phil.-hist. K1. 1928, 1-44; V. Brøndal, Les parties du discours, Copenhague 1928; - , L'autonomie de la syntaxe, Psychologie du langage, Paris 1933, 217 vv.; -, Morfologi og Syntax, København 1932; 19-35; E. Otto, Die Wortarten, GRM 16 (1928), 417-24; A. Lombard, Les membres de la proposition française, Moderna Språk 23 (1929); K. Bühler, Sprachtheorie, Jena 1934, 299-303; H. Delacroix, Le langage et la pensée ${ }^{2}$, Paris 1930, 216-225; H. J. Pos, De eenheid der Syntaxis, A'dam 1930; -, Opmerkingen over het adjectief; Donum natalicium-Schrijnen 1929; - Ueber den Aufbau der grammatischen Interpretation, Deutsche Blätter für Philosophie, 6 (1932), 295 v.v.; -, De taal als symbolische Functie, De uitdrukkingswijze der wetenschap, 1934 ; Les particules, leurs fonctions logiques et affectives. Recherches philosophiques III (1934), 321 vv.; M. J. Langeveld, Taal en denken, Groningen 1934, 51-55; A. Reichling, Het woord; Nijmegen 1935; R. W. Zandvoort, A handbook of english grammar, Groningen 1945; 248 vv. 
heeft kunnen aflezen. In de primitieve talen heeft men er echter weer andere. Zelfs van een zekere wankelheid in de indeling kan men de talen met possessieve flectie niet beschuldigen. Men vergete niet dat tuen in een dergelijk geval, juist zoals steeds in zulke omstandigheden, het ene gesloten systeem meet en beoordeelt naar de structuur van het andere, en niet naar een absolute norm. In de westerse talen nu is de „woord"soort (de term zelf zegt het reeds) min of meer tot een vast lexicologisch kenmerk geworden, dat men veelal regelmatig in de woordenboeken vermeldt, juist zoals b.v. het nominale woordgeslacht. Dit hangt ten nauwste samen met de uiterst ver ontwikkelde en gedifferentiëerde vormgeving, die men hier aantreft. Het gehele woord is daardoor min of meer geindividualiseerd. Het staat tot op zekere hoogte los van het zinsverband, waarin dit van nature past en waarin dit toch pas zijn eigenlijke waarde verkrijgt. In de primitieve talen is de morphologische specialisering echter rudimentair gebleven. Het woord is nu daarom ook dichter blijven staan bij de zin. Het is slechts als één steentje uit het grote geheel, en is niet tot zelfstandigheid gekomen. Hoe redelijk dus, dat men hier nu in veel gevallen eerst ook het syntactische verband moet raadplegen vóór men kan zeggen, welke precies de betekenis en de indeling is van een bepaalde vorm! Iets vreemds of abnormaals is daarin niet gelegen. Integendeel! In de gegeven omstandigheden kon het, bij wijze van spreken, eenvoudig niet anders zijn geweest.

2. Wat speciaal het dooreenlopen van de personale en de possessieve kategorieën betreft, dat de talen met possessieve flectie kenmerkt, levert de analyse zeker nog meer concrete winst. De personalia immers wijzen, zoals hierboven reeds in ander verband is uiteengezet, op het zelfbewuste „ik”, de kern van de gehele persoon, de grootheid die alle ervaringen heeft en tot een eenheid samenbindt, of ook wel op de gehele persoon als zodanig. De possessiva daarentegen noemen enkel de peripherie der persoonlijkheid, het gedeelte daarvan dat buiten het strikte ,ik" is gelegen ${ }^{159}$ ). Men kan de verhouding tussen de westerse

15:9) G. Hildebrand, Land und Leute und der Begriff der Vertretung, Ges. Aufsätze und Vorträge, Leipzig 1890, 64-76; G. Krueger, Die Uebertragung im sprachlichen Leben, Dresden 1900, 25-31, et passim; Th. Kalepky, Stilistisches, Zs. für fra. S. u. Lit. 41 (1913), 257-60; L. Spitzer, Persona pro re, ibid. 44 (1917), 240-5; - , Aufsätze zur romanischen Syntax und Stilistik, Halle 1918; 232-46; W. Havers, Handbuch der erklärenden Syntax, Heidelberg 1931, 165, 
talen, die meestal gesplitste kategorieën bezitten en de talen met possessieve flectie met hun ongesplitste kategorieën, ongeveer als volgt voorstellen :
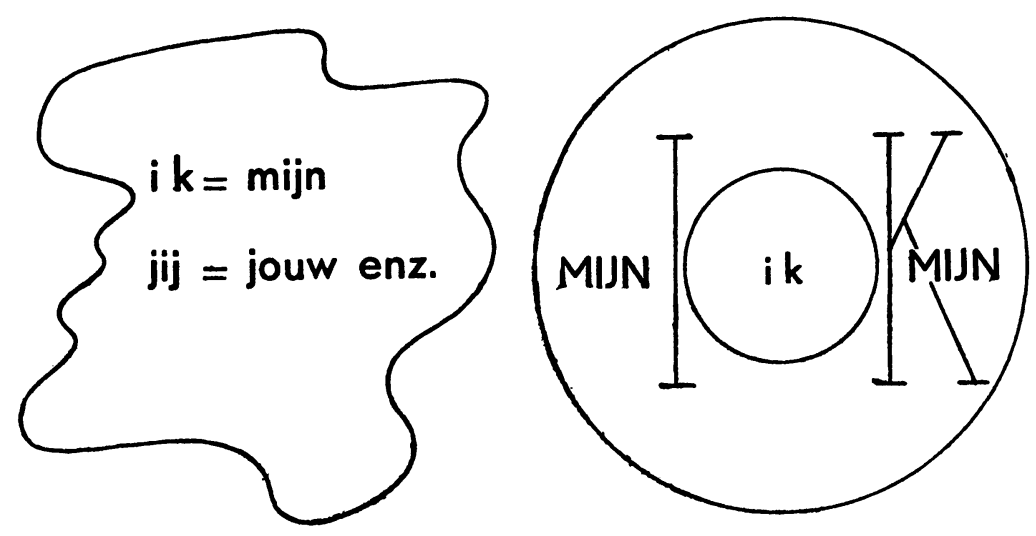

In de primitieve talen met possessieve flectie kent men m.a.w. slechts één vorm voor de subjectieve pool van het ervaringsleven als geheel. De aanduiding is vaag en totaal ${ }^{160}$ ). De typische overgangspositie, die

204, 258, 269; J. Wils, De persoon in de taal, OT 6 (1937), 177; R. Hirzel, Die Person, Begriff und Name derselben im Altertum, Sitz. Ber. Bayr. Akad. d. Wiss. 1914 ; H. Rheinfelder, Das Wort „persona”, Halle 1928; W. de Vries, Opmerkingen over Nederlandsche syntaxis; Tijdschrift voor nedl. taal en letterk. 29 (1910), 148 vv.; R. Blümel, „Verbindung von Ganzem und Teil” und andere Gruppen syntaktischer Beziehung in der neuhochdeutschen Umgangssprache; IF 34 (1914-45), 285 vv. Zie verder ook L. Hjelmslev, La nature du pronom, Mélanges van Ginneken, 1937, 51.

100) Wij hebben hier het probleem van de possessieve flectie, en dat van de verbale flectietypen in het algemeen, natuurlijk slechts te bespreken van het standpunt der taalwetenschap. Buiten het terrein der linguistiek dienen we ons niet te bewegen. Aan de andere kant wordt het op een moment als dit echter wel héél duidelijk, hoe nauw ons vraagstuk samenhangt met het grote vraagstuk van de "primitieve” mentaliteit in het algemeen. De sociologen en ethnologen zijn op dit punt in twee vrij scherp gescheiden kampen verdeeld. De franse school, waarvoor vooral L. Lévy-Bruhl als woordvoerder is opgetreden, neemt aan, dat het individu in de "primitieve" culturen enkel tot zijn recht komt in zoverre het deel heeft ,à l'essence de son groupe”. „Le groupement social (clan ou Sippe)... (est) la véritable unité, dont l'individu est un simple élément". De cultuur-historische school van Weenen, maar ten onzent b.v. ook Prof. Steinmetz en zijn school (Fahrenfort, Hofstra e.a.), hebben daartegenover steeds volgehouden, dat er tussen de westersche en de "primitieve" volkeren in dit opzicht van géén 
het „mijn” in het Westen inneemt tussen het „ik” en de objectieve wereld, ontbreekt. Wat niet geheel in de "subjectieve” orde valt, deelt onmiddellijk in de „objectieve”, die slechts onduidelijk daarvan gescheiden is. Iets ,,vreemds” of "minderwaardigs” is ook daarin alweer niet gelegen. De mens leeft nu eenmaal gewoonlijk niet in zijn „ik”

enkel principieel verschil sprake was. De kategorie der individualiteit wordt bij beide groepen in de grond op geheel dezelfde wijze doorleefd.

De voornaamste reden waarom dit gewichtige debat zolang gerekt wordt is o.i. wel hierin gelegen, dat de beide tegenover elkander staande partijen de kwestie elk van een geheel andere zijde benaderen. De sociologen laten zich allereerst bij hun beschouwingen door de sociale feiten leiden, maar de cultuurhistorici gaan van een philosophische notie uit. Welnu, de taalkunde kan, naar het ons voorkomt, in dit verband een niveau bieden, waarop de beide groepen elkaar nu werkelijk direct kunnen ontmoeten. De ongelijkheid der beiderzijds gebruikte wapenen, kan op deze wijze worden opgeheven. Men is dan uit de impasse gered, en een oplossing kan worden voorbereid. Ziet men de zaken zo, dan zou men zeker zeggen, dat het gelijk in dit geval over beide groepen verdeeld is. De waarheid schijnt hier in het midden te liggen. De "primitieve" mens bezit zonder twijfel een eigen individualiteit; hij is méér, annmerkelijk méér dan enkel een lid van zijn clan of van zijn leeftijdsklasse. De structuur van zijn gehele persoonlijkheid is echter veel vager en minder gedifferentieerd dan in het Westen. De "primitief” doorleeft zijn onverwisselbaarheid slechts zelden. Het sociale in zijn wezen domineert. In het Avondland daarentegen is het steeds allereerst het eigen ,ik”, waarvan de mens uitgaat bij zijn denken, voelen en handelen. En dit "ik" is het ook, waartoe hij het andere, dat hij op zijn weg ontmoet, herleidt. Het onderscheid ligt hier, met andere woorden, niet in de objectieve orde, maar in de psychologische orde. $\mathrm{Er}$ is geen verschil in wezen tussen West en Oost, maar wel een verschil in de aard en het type van de doorleving daarvan. Overigens kunnen de verschillende groepen, leeftijden enz. nòch in het Westen nòch in het Oosten op één lijn worden gesteld. Juist ook het verschil tussen de verbale flectietypen in de talen bewijst, dat men hier zorgvuldig onderscheid moet maken alsvorens te oordelen. Van absolute normen is bij dit alles géén sprake. Het is enkel de typologie die de doorslag geeft. Psychologen als H. Werner e.a. hebben een oplossing, zoals die hier kort geschetst is, reeds lang voor ogen gehad. Voor ons doel volstaan we daarom verder met enige karakteristieke citaten uit $H$. Werner's Entwicklungspsychologie, Leipzig 1926. „(Die primitive Personalität) ist ihrer Struktur nach viel ,komplexer' (als die des erwachsenen Kulturmenschen): der Gegensatz zwischen der Ich-Person und den übrigen Personen der Gesellschaft, zwischen dem Ich und der Welt der Gegenstände ist um so weniger scharf ausgeprägt, in je primitivere Zonen der Naturmenschheit man vordringt” (298). „(Die) Art der Ich-Existenz des Primitiven (ist) ... viel weniger von der Du-Welt und der Welt der übergeordneten Stammesgenossenschaft abgesetzt, (erscheint) insofern komplexer, als in unseren Sphären der individuell scharf ausgeprägten Persönlichkeit" (299). (Die) primitive Person (ist) viel weniger gegliedert nach wesentlichen und unwesentlichen Merkmalen; weniger gegliedert in kernhafte Zentren, welche das Ich wesensbestimmen, und in blose, anhängende, periphere Eigenschaften" (301) ... ,(Der) Ichhof des Primitiven (ist) umfassender als beim höhern, selbstbewusten Kulturmenschen...; (er) umfaszt viel mehr als den blosz per- 
als in een gesloten veld, tegenover de wereld, zo leert de moderne psychologie uitdrukkelijk, maar in het goed-geordende verband dat er tussen deze beide bestaat. En pas daarin krijgen deze beide ten volle zin en betekenis voor elkaar, en worden zij tot wat zij tenslotte $\mathbf{z i j n}{ }^{\mathbf{1 6 1}}$ ). Van de scheidingen tussen het subjectieve en het objectieve wordt men zich natuurlijk wel op bepaalde momenten duidelijk bewust, maar de gelegenheden waarbij dit geschiedt zijn niet zo vele in getal, en ook de scherpte der tegenstelling kan geval voor geval aanmerkelijk wisselen. We hebben daarover reeds uitvoerig gesproken (85 vv.).

Moet hier dus aan één van de beide zijden van een zekere eenzijdigheid of een overdrijving worden gesproken, dan zijn het wel eerder de westerse talen die daarvoor in aanmerking komen dan de talen met possessieve flectie. De westerse talen immers scheiden hetgeen van nature bijeen behoort, en scheppen daarbij zelfs gradaties en tegenstellingen, die eerder op het abstraherende denken schijnen te berusten dan op het natuurlijke, ongedifferentiëerde doorleven der dingen. Het possessieve flectietype staat in deze zin dichter bij de werkelijkheid dan b.v. de flectie der indogermaanse talen. Steinthal heeft dit reeds zeer terecht aangevoeld (68 vv.).

3. Wat tenslotte de genitivische subjectsbepaling betreft, we hebben in de voorgaande hoofdstukken bij onze tocht door de verschillende talen reeds verscheidene van dergelijke constructietypen ontmoet. We hebben gevonden, dat men hier voor een uiterst eenvoudig en ongedifferentiëerd type van subject staat. De taalaanduiding berust op niets anders dan het eerste en meest sprekende kenmerk van elke handelingssituatie, dat deze n.l. als zodanig een verder niet te ontleden geheel vormt. De wijze waarop het ,i $k$ " dat reageert en de omgeving die daarop terugwerkt zich precies verhouden, wordt niet uitgedrukt $\left.{ }^{162}\right)$. De nuance

sonalen Kern” (305). „Die primitive Ich-Person ist (daher) nicht nur komplex, sondern auch viel weniger in ihrer Eigentümlichkeit und Konstanz bestimmt. Die Eigenart, die den Personen gegenüber den Dingen der Natur zukommt, ist ein Produkt längerer Entwicklung" (312).

16-) O. Janssen, Das erlebende Ich und sein Dasein, Berlin 1932, 93-99; A. Schütz, Der sinnhafte Aufbau der sozialen Welt, Wien 1932; L. von Wiese, Allgemeine Soziologie, Bd. I, Berlin 1924; 102 vv.; Bd. II (1929), 64 vv.; A. A. Grünbaum, Het ik-bewustzijn en de psychische ontwikkeling; Utrecht 1928, 15, 14.

162) E. Cassirer, Philosophie der symbolischen Formen I, Die Sprache 1923 „Die Bezeichnung des Vorgangs haftet hier (bei der possessiven Flexion) zunächst weder die Bezeichnung auf einen Tätigen noch die auf einen Leidenden an: das Verbum konstatiert einfach den Eintritt des Vorgangs selbst, ohne ihn ausdrück- 
is eerder statisch-descriptief, dan wel dynamisch-verbaal. Welnu, de talen met possessieve flectie vormen eenvoudig de pronominale parallel daarvan. Wie de nominale genitivische subjectsbepaling als reeël en taalkundig-volwaardig aanvaardt, kan redelijkerwijze ook tegen de possessieve flectie zijn stem niet verheffen. Ook hier blijven het ,ik" en de aard der zich voltrekkende handeling in de schaduw; het volle licht valt alleen op het feit van hun verbondenheid, op het handelingsgebeuren als verder ondeelbare totaliteit.

Men ziet hoe nauw dit derde kenmerk bij het zojuist besprokene aansluit. Men benadert hier blijkbaar in beide gevallen dezelfde zaak. Alleen telkens van een andere kant. Dat de verbale dynamiek bij de possessieve flectie minder tot haar recht komt dan b.v. bij het flectietype der oudere indo-europese talen hebben Steinthal, Fr. Müller e.a. dus zeker goed gezien (67 vv.). Evenwel, een recht om in dit geval niet van „subject” en ,flectie” te spreken, kan men daaraan niet ontlenen. Zou men b.v. ook een dergelijke nuance willen laten uitkomen in de vertaling van een tontemboan-vorm als het zoëven geciteerde sisile $\dot{n}$ - $k u$, dan zou men misschien ,ik-ben-aan-het-vertellen; vanwege-mij-wordtdaar-verteld; van-mij-uit zegt-het-daar", of iets dergelijks, kunnen zetten.

\section{Moderne europese parallellen.}

In de indonesische grammatica staat men in het algemeen zéér huiverig tegenover de voorbeelden van possessieve flectie die in de archipeltalen voorkomen. Dat het hier over een werkelijke verbale conjugatie gaat, wordt gewoonlijk niet aangenomen (79). Het is daarom wellicht nuttig erop te wijzen, hoe ook de moderne europese talen op dit punt allerlei trekken vertonen die niet zover van de indonesische karakteristiek zijn verwijderd. Alleen één groot verschil blijft daarbij natuurlijk steeds bestaan. De possessiva treden in de europese talen nooit als verbale persoonsexponenten op. Verder echter keren de drie zojuist genoemde trekken in precies dezelfde constellatie terug. En men staat hier in werkelijkheid dus veel dichter bij ,bekend” terrein dan meestal wel wordt vermoed. Dat ook in west-Europa de dynamische

lich an die Energie eines Subjekts zu knüpfen oder die Beziehung zu dem Objekt, das von ihm betroffen wird, in der Verbalform selbst kenntlich zu machen" (215). Vgl. ook H. Steinthal-F. Misteli, Charakteristik der hauptsächlichsten Typen des Sprachbaues; op. cit. 58,48 vv. 
kracht van het werkwoord anzienlijk is verminderd, is hierboven bij de bespreking van het subject reeds gebleken (102 v.). Ook het verval van de persoonsconjugatie in talen als het engels, deens, nederlands vormt zonder twijfel een sterke anwijzing in deze richting (89).

1. Welnu, blijkbaar in samenhang met deze vervaging der dynamiek is nu ook in talen als het engels b.v. herhaaldelijk het morphologische onderscheid tussen nomen en verbum komen te vervallen ${ }^{163}$ ). Juist als in de ,primitieve" talen rest er nu veelal niets anders dan het syntactische verband, dat over de indeling kan beslissen. De oude distincties zijn wel niet geheel verdwenen, maar ze zijn toch aanmerkelijk van karakter veranderd. I love maar my love; we talk maar our talk. Love, talk zijn enkel en alleen werkwoord in de vooropgeplaatste voorbeelden (d.w.z. ze worden gevoeld als behorende tot dezelfde kategorie als (to) give, bleed, get etc.) door de combinatie met $I$, we die evident pure personalia zijn. Maar omgekeerd gelden dezelfde vormen in de volgende voorbeelden als nominaal, wegens het verband met possessiva als $m y$, our. In het deens komen verscheidene analoge gevallen voor.

2. Ook de grenzen tussen de personalia en de possessiva zijn in de west-europese talen zeker minder scherp dan de normatieve grammatica het gewoonlijk wel voorstelt ${ }^{164}$ ). Het possessivum is in onze talen weinig anders dan een algemene index van subjectiviteit. De speciale verhouding tot het ,ik" wordt verder niet in bijzonderheden aangeduid en genoemd; laat staan, dat daarbij van een zeker juridisch opgevat ,bezit" sprake zou zijn. Juist zo is ook onze nominale genitief eerder als een globale status adstructus te beschouwen dan wel als een „genitief" in de beperkte zin van b.v. de klassieke talen. Het feit der onderschikking ten opzichte van het nomen regens is beslissend, de aard en de vorm daarvan zijn irrelevant. Zo kan een vorm als mijn boek, schrijft Schuchardt, niet alleen betekenen ,het boek dat ik bezit”, maar evengoed „het boek dat ik geschreven heb” of „het boek dat aan mij is opgedragen". Een redacteur dient evengoed zijn lezers als zijn chef, zijn partij, zijn land. Een taxichauffeur kan evengoed van zijn wagen als van zijn vrachtje spreken, hij heeft evengoed zijn vroure en kinderen als zijn beurt om voor te rijden enz. De juiste interpretatie

163) O. Jespersen, The essentials of english grammar 73; R. W. Zandvoort, A handbook of english grammar, 248 vv.

164) Zie pag. 130, noot 159. 
hangt dus van de omstandigheden af ; de persoon wordt telkens slechts even vluchtig aan de peripherie geraakt.

Beziet men de zaken aldus, dan wordt het ook begrijpelijk waarom in onze cultuurtalen soms zelfs het gebruiksgebied van de personalia en de possessiva regelrecht in elkander gaat overlopen. Gewoonlijk zijn het de personalia die dan tevens de functie van het possessief vervullen. Hun zeer algemene betekenis geeft daartoe natuurlijk geredelijk aanleiding. Maar er zijn toch ook wel gevallen, waarin de ontwikkeling juist in de omgekeerde zin verloopt, en waarin dus juist de personalia terrein verliezen. Een zeer ver verspreid voorbeeld van dit laatste heeft men bij de scheldwoorden. In een hele reeks van oudere en jongere europese talen wordt de persoon daarbij niet door een personale maar door een possessief angeduid ${ }^{165}$ ). Het is de speciale gevoelsnuance, die hier tot de vage aanduiding aanleiding schijnt te geven. Portug. sua besta!; spa. pobrecitos de nosotros! desdichada de mi; zweeds din narr! edra bovar!; roemeens nenorocitul de mine, ,ich Unglücklicher (Armer)"; nedl. volkstaal Jouw lelijke schavuit dat je d'r bent!

Hoe ook in onze nederlandse dialecten vaak possessiva worden gebruikt waar het algemeen beschaafd personalia heeft, is algemeen bekend. Het is geen toeval dat onze onderwijzers er vaak over klagen, dat sommige van hun leerlingen het onderscheid tussen jou en jouw, $u$ en $u w$ maar niet geleerd kunnen krijgen. Zijn heeft het gedaan ('s-Gravenhage). Da's feur min (jouw) heur! (Nijmegen). Ons word nie deur die Regering beskerm nie (Z.-Afrika). Zeer bekend zijn zegswijzen als Ons kent ons enz.

Het gebruik van het personale in ,possessieve” functie, juist het omgekeerde verschijnsel dus als zoëven, vindt men herhaaldelijk bij het noemen van allerlei verder afliggende, maar sterk subjectief getinte zaken. Wat de logica hier ook distingueert (van haar standpunt terecht), het gaat in deze gevallen over delen van de psychologische persoon. En van „bezit”, als een objectieve, tastbare relatie, is dus geen sprake. Hgd. Brennen Sie? (sigaar). Mein Wirt hat mich gesteigert (huur). Ich möchte mich gern verändern (dienstbode). Wir sind hier voll (coupé). Einen gründen (iemands zaak in een N.V. omzetten). Schult hät kalwet (Altmark). Fra. remuer un enfant (verschonen). On l'a saisi

165) Hugo Schuchardt-Brevier (ed. L. Spitzer), Halle 1922; 198; H. Jensen, Neudänische Syntax, Heidelberg 1923; 93. 
(bezittingen). Il a été grêlé, Sucrez vous! Eng. Here you are (wat u zocht). To cut one (vriendschap). They have been asked in church (huwelijksafkondiging). If we are opened, we shall have an easy communication with the city (straat). Vgl. ook uitdrukkingen als $\mathrm{He}$ is a Victoria Cross, a good hand at fensing, bad form. She is a good fun, a caution, a frost. Nedl. Ik brand al (sigaar). Jij bent achter (horloge). Wacht even, ik ben nog niet gestemd (viool). Het kind verwisselen (verschonen).

3. Ook genitivische subjectsbepalingen tenslotte zijn in de westeuropese talen verre van zeldzaam. Men vindt ze vrij regelmatig in die gevallen, zo kan men in het algemeen zeggen, waar men om welke reden dan ook, de figuur van de agens in het duister wil laten, of wanneer het eerder op de veroorzaakte toestand aankomt dan wel op de handeling zelf. Zowel nominale als pronominale voorbeelden komen voor. Zeer gewoon is allereerst de genitivische bepaling in de passieve constructie van het duits. Inderdaad valt de nadruk hier ook op het logische object. De wijze waarop de handeling tot stand komt staat op het tweede plan. Dieser Brief ist mir von meinem Bruder gebracht worden. Verder nog constructies als Unter den von mir aufgezeichneten Wörtern möchte ich hervorheben....; Müde von der Arbeit; vom Glanz vor ihm trenneten sich die Wolken (Luther); willst $d u$ von unsern Händen sterben (id.); von Gottes Gnaden; seitens des Königs; ich lasse mir von ihm nichts befehlen enz. Eng. to be proud, glad of; to take it ill of; sick of measles, delays; forsaken of God and men; it was kind of you to say so; it has the approval of his master. Fra. combler de bienfaits; orner de fleurs; souffrir d'une maladie; cela part d'un bon coeur; de vive voix; je sais cela de bonne part; venir de la part de qn.; va le trouver de ma part; c'est de ma faute; il est frappé de ce coup. Nedl. Van iemand een standje krijgen; van honger sterven; van koude beven; hij is van Lotje getikt. Van (vanwege) het Departement van Sociale Zaken deelt men ons mede.... (persbericht). Lat. amor patris (= pater amat); coniuratio Catilinae (=C. coniuravit);

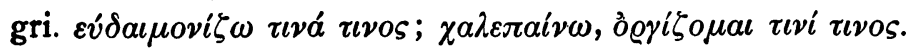




\section{HOOFDSTUK XIII.}

\section{Het passieve werkwoord.}

Het debat over het passieve werkwoord moge tot een meer recente en ,verlichte" periode van de taalwetenschap behoren, minder heftig of minder principiëel dan dat over de possessieve flectie was het allerminst. Bij slot van rekening vloeien de moeilijkheden in beide gevallen ook uit dezelfde bron: de uiterst gewichtige maar ook zeer moeilijke opgave om begrippen als ,subject en ,zin” te vinden, die niet alleen aan alle theoretisch te stellen eisen voldoen, maar evenzeer ten aanzien van de vele en steeds weer wisselende taalkundige feiten (83). Hoe is nu het resultaat? Wat valt er nu tenslotte van het passieve werkwoord te denken? Men kan naar onze mening, ook voor dit type, weer drie kenmerken opstellen. Het eerste heeft betrekking op het subject; de beide andere sluiten aan bij de aard van het object. Het drietal hangt natuurlijk ook hier innig samen.

Het eerste kenmerk luidt, dat de agensaanduiding bij het passieve werkwoord in de ergatief (instrumentalis) staat. Volgens de heersende taalkundige voorkeursrichting komt de agens hier immers enkel tot uitdrukking als de personale organisatievorm van de handeling, als de instantie waardoor deze lijn en stijl verkrijgt. Verder gaat de ontleding niet. De actie wordt als een zekere "staat" en niet als een „daad” aangeduid en weergegeven ${ }^{166}$ ).

Juist omdat de verbale dynamiek bij het passieve werkwoord slechts gedeeltelijk determinerend is, zo luidt het tweede kenmerk, treedt het object hier ook min of meer op de achtergrond. De uitdrukkingsvorm daarvoor is in ieder geval onspecifiek. Men kan op dit punt in de talen minstens twee typen onderscheiden. Bij het eerste, minder ver ontwikkelde type, waarvan het baskisch als voorbeeld kan gelden, blijft het verdere verloop der dynamiek totaal in het duister. Het object staat nu daarom in de intransitivus, d.w.z. in juist dezelfde naamval als waarin ook het subject komt te staan van de actie die geheel binnen de eigen persoon van het subject besloten blijft. $D$-akar- $t$, vanwege-mij wordt-hijdaar-gedragen, door-mij wordt-hij-daar-gedragen". Bij het tweede, enigszins verder geëvolueerde type wordt de handeling, althans ten dele, wel degelijk ook in haar centrifugale ontwikkeling gevolgd. De speciale

106) Zie ook M. Leenhardt, Langues et dialectes de 1'Austro-Mélanésie, Introduction XXXIX. 
aard van de verhouding tot het object komt echter ook nu nog niet tot uitdrukking. En zo vindt men daarvoor in de taal ook enkel de algemene verbindingsnaamval bij uitstek: de genitief. Een voorbeeld daarvan heeft men in de reeds genoemde indianentalen (110). Tsimshian $m$-wa'yin- $u$,,vanwege-jou het-gevonden-worden-daar-vanmij” ; $n-d z a^{\prime} k d-\varepsilon n$,door-middel-van-mij dat-doden-daar-van-jou” ${ }^{167}$ ).

Het derde kenmerk tenslotte is niets anders dan de toepassing van het tweede op de leer der genera verbi. Schuchardt, die van aphorismen houdt, schertst ergens, dat men alle reden heeft een werkwoordstype voor "passief" te houden, indien alle daartoe behorende vormen van het ,actieve" genustype zijn. Dit kan men zeker toegeven. Het ,passieve" werkwoord is (evenals overigens het ,possessieve” werkwoord) activum tantum. En de oorzaak daarvan is duidelijk. De zich voltrekkende dynamiek heeft voor dit verbale type géén beslissende betekenis. En a fortiori wordt hier dus ook niet de tegenstelling tussen een ,,actief"-centrifugale en een ,passief”-centripetale beweging uitgedrukt. Alle verbale vormen zijn van één en hetzelfde type, dat in de grammatica's, naar analogie van wat er bij het energetische werkwoord geschiedt, gewoonlijk als ,actief” wordt aangeduid.

Echter twee opmerkingen kan men hieraan nog toevoegen. Vooreerst is het misschien voorzichtiger, de theoretische formulering zo te kiezen, dat het „passieve” werkwoord de tegenstelling tussen het ,actieve” en het ,passieve" genustype, zoals de dynamisch-energetische flectievorm die bezit, niet kent. En verder is ook hier bij de latere ontwikkeling, althans in bepaalde gevallen, weer een scherper ontplooiing van het vormsysteem gevolgd. We zullen hierachter b.v. in de indonesische talen typen van het ,passieve" werkwoord ontmoeten, die - althans tot op zekere hoogte - wèl iets van de genusdistinctie bezitten, en dit ook in de morphologie duidelijk reflecteren (198 vv.).

Ziet men de zaken zo, dan kan men de verhouding van het ,passieve” type tot de beide andere flectievormen zeer scherp overzien en karakteriseren. En tegelijkertijd blijkt meer dan ooit, hoe begrijpelijk in de grond het daarover gevoerde ,beroemde" debat geweest is. Zo ooit in de taalwetenschap het ontstaan en het verloop van een bepaalde theoretische strijd zin had, dan was dit hier. En Schuchardt heeft zeker niet over-

167) F. Boas, Handbook of american indian languages I (1911), 385. Zie ook E. Sapir-M. Swadesh, American Indian Categories, Word 2 (1946), 103; A. Burger, Voorlopige Manggaraise Spraakkunst, BTLV 103 (1946), 119-124. 
dreven, toen hij schreef, dat bij dit debat niet alleen wetenschappelijke meningen tegenover elkander stonden, maar zelfs ook wereldbeschouwingen en de persoonlijke typen der debatterende geleerden zelf.

Er was oppositie en onzekerheid van vele zijden, naar men zich herinnert (69 v., 74 v.). Een extreem ,activist” als Trombetti meende, dat de verbale conjugatie in ieder geval tot stand moest zijn gekomen in een sfeer, waarin de actie door de agens duidelijk en volkomen werd gevoeld en uitgedrukt als een dramatisch en centrifugaal verlopend „doen”. Het taalkundig subject diende z.i. daarom steeds op straffe van kategoriale nietigheid, de agens voor te stellen als het dynamischenergetische centrum van de gehele handelingssituatie (graad der dynamiek: 100). Juist zo houdt Meillet, dat het werkwoord „essentiellement actif" is (graad in ieder geval: aanmerkelijk meer dan nihil). Aan dergelijke eisen voldoet het ,passieve" werkwoord niet, en daarom verdween dit type zowel bij Trombetti als bij Meillet, in hun gedachtengang zeker consequent, ineens en voorgoed van de lijst. Finck had een veel ruimer opvatting aangaande de kategorie van het subject. Weinig plastische figuur als hij was, zat hij aan de andere kant echter vast aan de gedachte (zonder deze ooit met even zovele woorden uit te spreken), dat een handeling niets anders kon zijn dan de secundaire dynamisering van een daaraan voorafgaande statisch-nominale phase. In ieder „subject" (behalve misschien in dat van het actief-energetische werkwoord), schuilt voor hem in oorsprong daarom iets van een genitief (graad van dynamiek: niet veel meer dan nihil). Ook in dit laatste schema past de ergatief-instrumentalis van het „passieve” werkwoord zeker niet. En zo kreeg dit type ook in Finck's ontwikkelingsschema weer slechts een afgeleide en zéér subsidiaire plaats. Prof. C. C. Uhlenbeck tenslotte vat de term ,passief” in de verbinding ,passief werkwoord" in absolute zin op. Naar zijn mening blijft de eigenlijke agens voor de primitieve mens steeds een verborgen grootheid. Deze voelt zich enkel als een zeker instrument, waarlangs ,de machten welke zijn ikheid beheersen" het verlangde resultaat tot stand brengen. De graad der als autonoom gevoelde dynamiek is hier dus: practisch nihil.

Welnu, het wil ons voorkomen dat al de genoemde geleerden elk hun deel van de waarheid gevonden hebben. $Z \mathrm{ij}$ hebben deze ook hier weer enkel telkens van een andere zijde benaderd. De tegenstelling tussen de verschillende beschreven standpunten is daarom in werkelijkheid veel geringer dan de gegeven korte samenvatting misschien zou doen denken. 
De kwestie is dat men het „passieve” werkwoord o.i. het best als het half-actieve of het gematigd-actieve werkwoord kan beschouwen. De drie kenmerken van hierboven worden in deze nieuwe formulering ineens kort en goed samengevat. De juiste oplossing ligt hier m.a.w. in het midden. De door Trombetti en Meillet gestelde eis is in beginsel zeker zeer redelijk. Het werkwoord is een ,actieve" uitdrukkingsvorm, of het is niet. Het ,passieve" werkwoord voldoet aan dit desideratum echter ten volle. En niet alleen het „passieve” werkwoord, maar ook b.v. het zojuist beschreven possessieve flectietype, voldoet daaraan. Het verschil is alleen maar, dat niet al deze flectievormen op dezelfde reijze en in dezelfde mate de activiteit van de agens weergeven.

In dit opzicht loopt er een stijgende lijn door het stelsel, waarvan het dynamisch-energetische type van b.v. de oudere indo-europese talen het hoogtepunt vormt, maar waarin de andere lager geplaatste typen evenzeer delen. Hier ligt een rijkdom in de mogelijkheden, die Meillet en Trombetti niet hebben gezien.

Zo drukt de possessieve flectie, naar reeds gebleken is, bij slot van rekening niets anders uit dan de allernauwste verbondenheid, die er juist op het moment van het handelen tussen het ik en de wereld bestaat (133). Daarom staat de agens hier ook enkel in de algemene verbindingsnaamval bij uitstek, de genitief. De centrifugale dynamiek komt verder niet als zodanig tot uitdrukking. De ,overgang” van de handeling op de omgeving is niet aanschouwelijk (graad b.v. 10 of 20). Tontemboan sisile $\dot{n}-k u$,,vanwege-mij vertelt-het-daar”; ,van-mijn-kant dat-vertellen-daar". Bij het energetisch-plastische type daarentegen, zoals dit b.v. in de oudere indo-europese talen voorkomt, is het juist deze zich uitlevende dynamiek die het speciale punt van uitgang vormt. De wereld geldt daarbij min of meer als incommensurabile, te overwinnen weerstand. De handeling wordt nu uitdrukkelijk als een „,daad” gezien, waarvan de agens het centrifugale, dynamisch-actieve middelpunt vormt. De patiens is daartegenover slechts een ,getroffen", een afgeleide en secundaire grootheid (graad 100). Skr. simha gajam hanti „de-leeuw-die-machtige brengt-dood over-de-olifant-die-verslagene”; lat. haec adeptus sum, ,door-mijn-eigen-onweerstaanbaar-doen heb-ikdit-verkregen".

Het „passieve" werkwoord tenslotte, waarom het ons te doen is, vermijdt nu evenzeer, naar het ons voorkomt, de al te grote vaagheid en globaliteit die men misschien aan de possessieve flectie kan ten laste 
leggen, als anderzijds het eenzijdige hybridisme waaraan de energetischdynamische flectie zeker mank gaat. De handeling wordt nu ,zuständlich" ervaren, juist zoals dit b.v. ook bij het zeer jonge kind gedurende een bepaalde ontwikkelingsperiode het geval is. De "Steuerung”, het centrale concipiëren, richten en uitvoeren daarvan, domineert verder niet. En als subject vindt men daarom ook alleen een zekere globale aanduiding voor de organiserende instantie: een ergatief of een instrumentalis (graad 50).

Men ziet dus, dat van een tegenstelling tussen het "actieve" en het "passieve" werkwoord op dit punt géén sprake is. Evenmin zou men b.v. een halve grootheid de "tegenstelling" van de gehele grootheid, of het getal vijf de "tegenstelling" van het getal tien of twaalf kunnen noemen. Van modern standpunt kan men de verschillende flectietypen wellicht het best als een serie stilistische varianten naast elkander plaatsen. Het uitgedrukte objectieve feit is in alle gevallen hetzelfde, nl. de handeling van de agens. Het aspect daarvan waarop de practische taalaanduiding berust, is echter geval voor geval weer anders.

Wat de theorie van Prof. C. C. Uhlenbeck aangaat, het is zeker juist dat de agens bij het „passieve” werkwoord niet verder dan zijdelings tot uitdrukking komt. Meer dan een zekere stiliserende bemiddeling wordt er van hem niet genoemd. Taalkundig noch psychologisch brengt dit echter enige deficientie met zich mede. We hebben daarover in het negende hoofdstuk reeds uitvoerig gesproken ( $86 \mathrm{vv.}$.). Een volkomen „passiviteit” of ,gedreven worden” behoeft dit o.i. daarom niet te betekenen. Trombetti heeft de Leidse hoogleraar op dit punt ten onrechte aangevallen (77). Men kan alleen zeggen, dat de taalvorm bij het „passieve” werkwoord niet zo ,actief” is als deze wel zou hebben kunnen zijn, en zoals deze b.v. bij het energetisch-dynamische werkwoord is. Schuchardt schrijft in 1905 in een klein, maar daarom niet minder belangrijk artikel „Der Aktivus (d.i. het ergativisch-instrumentale subject van het „passieve” werkwoord) ist.... ein Adverb” ${ }^{168}$ ). Hier lag, naar onze mening, de juiste richting voor het verdere onderzoek reeds aangeduid. En was Schuchardt op dit punt later niet enigszins van richting veranderd, dan had het debat over het „passivisme” wellicht een geheel andere wending genomen.

168) Ueber den aktivischen und passivischen Charakter des Transitivs; IF 18, 530. 


\section{Overgangsvormen naar andere flectietypen. Moderne europese parallellen.}

We hebben ons tot nu toe nog enkel tot de theoretische analyse beperkt. De conclusie is, dat aan het ,passieve" werkwoord in de scala der flectietypen een tussenpositie moet worden toegekend. Het „passieve" werkwoord is meer dynamisch (meer „verbaal") dan het possessieve type, maar minder dynamisch (meer ,nominaal") dan het energetisch-actieve werkwoord. En mede om deze reden hebben wij zojuist van een gematigd-actief of half actief type gesproken. Gaat men nu echter de verschillende gevallen na, die hierboven in hoofdstuk IX en $\mathrm{X}$ practisch zijn ontleed, dan kan men daaruit, naar het ons wil toeschijnen, juist dezelfde gevolgtrekking afleiden. De theorie en de concrete taalgeschiedenis zijn in dit opzicht volkomen in overeenstemming. Men kan de flectietypen immers niet als volkomen gesloten uitdrukkingstelsels opvatten. Daartussen bestaan allerlei overgangen en kruisingen. En vooral als er twee of meer lagen van volkeren met elkander worden gemengd, wier talen elk oorspronkelijk andere flectietypen bezaten, dan blijven de aanvankelijke verschillen uiteraard in de nu gevormde mengtaal niet bewaard. Men krijgt de indruk in dergelijke gevallen, alsof er a.h.w. langs elk flectietype één of twee marges lopen, waarlangs de belendende typen dit kunnen benaderen, ja waarlangs zij c.q. daarin kunnen overgaan. En ook hier nu komt de tussenpositie van het "passieve" werkwoord duidelijk aan de dag. Men staat hier blijkbaar voor een type, dat uiterst bewegelijk is en dat zich gemakkelijk naar de speciale omstandigheden voegt.

Zo schijnt allereerst de afstand tussen de possessieve en de passieve typen in de menggevallen als vrij gering gevoeld te worden. Er bestaat hier blijkbaar een zekere natuurlijke structurele verwantschap. Het staat ook vast, dat er talen voorkomen waarin het werkwoord possessief en passief tegelijk is. De beide groepen van differentiërende kenmerken zijn dan nog niet scherp uitgekristalliseerd. Tussen de genitief en de ergatief (instrumentalis) met name bestaat nu nog géén, of althans geen scherp onderscheid. Men vindt iets dergelijks b.v. in het kaukasische ubych en kabardi (94). Schuchardt, die niet veel waardering had voor het possessieve type, heeft ten onrechte zulke talen geheel op één lijn gesteld met andere, waarin enkel het ,gewone", verder onvermengde 
passieve type voorkomt ${ }^{169}$ ). Een derde voorbeeld van zulk een possessief en tevens ,passief” werkwoord zullen ons hierachter nog de indonesische talen zelf (154) opleveren.

Wat de kloof tussen het passieve en het energetisch-actieve type aangaat, deze moge wat wijder zijn dan die tussen het possessieve en het passieve type, te overbruggen is deze daarom nog wel. Men heeft hier zelfs een dubbel stel feiten. Men ziet de verbinding in beginsel in twee richtingen geslagen worden, zowel „heen” als „terug”.

Zo kan men de reeds door Prof. C. C. Uhlenbeck besproken noordamerikaanse talen zeker beschouwen als een overgang in "stijgende” richting. Het flectietype is nu nog "passief”; men kan daaraan niet twijfelen. Maar het bezit van een objectskategorie, hoe primitief van aard dan ook, dat hier voorkomt, vormt anderzijds reeds een belangrijke analogie met het actief-energetische type, waar een dergelijke kategorie naar haar eigenlijke aard het eerste thuis is. Nog één stap verder, zou men geneigd zijn te zeggen, en er blijft op deze wijze van de ,orthodoxe" passieve trekken in het geheel niets meer over. Van half-aanschouwelijk wordt de verbale dynamiek nu geheel-aanschouwelijk. Uit het oorspronkelijke één-dimensionale verbale betekenissysteem ontstaat nu een twee-dimensionaal stelsel (104 vv.).

Juist omgekeerd vindt men een duidelijk voorbeeld van een type, waarin de verbale dynamiek secundair aanmerkelijk in kracht is teruggelopen, in de westerse cultuurtalen. Wij hebben daarop reeds meerdere malen gewezen $(95,116)$. En het merkwaardige is nu, dat bij deze regressie herhaaldelijk ook trekken aan de dag zijn getreden, die opvallend sterk herinneren aan die, welke we bij de analyse van het „passieve" werkwoord hebben gezien.

Men versta een dergelijke uitlating wel. De bedoeling is uiteraard niet te betogen, dat het moderne europese werkwoord in wezen een „passief” karakter draagt. Dit zou een evidente overdrijving zijn. En met evenveel reden zouden we dan aan het eind van het vorige hoofdstuk hebben kunnen betogen, dat b.v. ons contemporain nederlands werkwoord ,possessief" van aard was. Ook in dit opzicht bestaan er immers allerlei opvallende analogieën. De kwestie is alleen, dat de aanschouwelijkheid der verbale dynamiek in onze talen blijkbaar nog slechts partiëel is. De oude stijl van de ongelimiteerde dynamiek is nog

169) H. Schuchardt, Ueber den passiven Character des Transitivs in den kaukasischen Sprachen; SBAWW 133 (1895), 1-91. 
slechts bij enkele kernen in het gebruik onverzwakt gehandhaafd. De „passieve” (resp. de „possessieve”) trekken zijn m.a.w. enkel peripheer, en niet centraal.

1. Zo is het vooreerst een feit, dat er in de moderne west-europese talen naast de reeds besproken possessieve subjectsaanduidingen (eng. of, with; fra. de; nedl. van) herhaaldelijk ook een aantal dergelijke passieve constructies voorkomt. Bijzonder goed is de verhouding van beide typen onderzocht in het frans. Het onderscheid blijkt er daarbij duidelijk een te zijn naar de uitgedrukte graad van dynamiek. Dit is dus geheel volgens de verwachting, die men van comparatief standpunt reeds koesteren kon. Zo wordt b.v. volgens Karin Ringenson „l'agent actif" in het moderne frans steeds door par ingeleid. Maar men vindt $d e$ bij die werkwoorden, waar "(l'idée d'action) est absente ou d'une importance secondaire", zoals b.v. bij die van gevoelsreacties, zintuigelijke waarnemingen, intellectuele processen, enz. ${ }^{170}$ ). In het nederlands vindt men de vormen met door volgens Prof. Overdiep in een aantal onpersoonlijke constructies, waarbij het subject „op de achtergrond staat" ${ }^{171}$ ). Verder vooral in de ambtelijke stijl, omdat deze „voorzichtig, diplomatiek, opzettelijk generaliseerend” moet zijn. Dit zijn dus dezelfde nuancen, als ook in de andere talen terugkeren. $\mathrm{Er}$ is door één der Statenleden.... verwondering over die plotselinge rijkssteun uitgesproken. Er is door Ged. Staten op geantwoord, dat de rijkssteun wordt gegeven om de aparte ligging van Zeeuwes-Vlaanderen.

Andere talen kennen analoge distincties. Het vergelijkend onderzoek wijst uit, dat de oostelijke europese talen op dit punt in het algemeen eerder naar het possessieve type neigen (ital. rhetisch $d a$; roem. $d e$; hgd. von; zwe. av; de. af). maar de westelijke talen naar het krachtiger regelrecht-passieve type (fra. par; spa. port. por; nedl. door; eng. by; enz.). Het nederlands staat bij deze verdeling gewoonlijk op west-

170) L. Clédat, „De” et „par” après les verbes passifs ; Revue de philol. française et de littérature 14 (1900), 218-33. Hj. Kallin, Etude sur l'expression syntactique du rapport d'agent dans les langues romanes, diss. Upsala 1923. Karin Ringenson, $D e$ et par comme expression du rapport d'agent en français moderne. Neuphil. Mitteilungen 27 (1926), 76-94. Verder: A. Fischer, Der syntaktische Gebrauch der Partikeln of und from in Aelfric's Heiligenleben und in den Blickling-Homilien, diss. Leipzig 1908. A. Green, The dative of agency, diss. New York 1913. J. Wilde, Die passivischen und medialen Ausdrucksweisen eines objectiven Geschehens, diss. Leipzig 1913.

171) G. S. Overdiep, Stilistische grammatica van het moderne nederlandsch. $449,451$. 
europees standpunt. Fra. suivi par la police; les voitures sont entourées par les Touaregs (Haardt); précédée par les deux femmes (Bertrand) maar escortée de son mari (Maupassant) ; épuisé par le chagrin maar de fatigue; Pierre est aimé (vu, connu) de Paul. Eng. overwhelmed by the shock maar - with emotion; paralyzed by unaccountable discretion maar - with fear; torn by rage and fear maar - with anxiety, resentment.

2. De subjectskategorie is in de west-europese talen goeddeels verstard en abstract geworden. Een fijner toetssteen voor de "activiteit" of de ,passiviteit" van het werkwoord heeft men hier daarom misschien in de objectskategorie. Welnu, alle grammatici zijn het erover eens, dat het object in de moderne cultuurtalen in een zeer groot aantal gevallen nauwelijks van een gewone verbale bepaling te onderscheiden valt. De overgang tussen de beide kategorieën is vloeiend en onzeker geworden. Was de verbale dynamiek hier voor de taalaanduiding beslissend gebleven, dan zou iets dergelijks natuurlijk onmogelijk zijn geweest.

Een karakteristiek feit is b.v., dat in de moderne europese talen soms niet alleen het directe object in de passieve constructie tot onderwerp van de zin kan worden, maar ook een datief ; vooral als deze laatste een persoonsnaam is, maar het directe object een zaaknaam. De verklaring van dit laatste verschijnsel is wel deze, dat het directe en het indirecte object in de west-europese talen min of meer op één lijn zijn komen te staan, juist doordat de betekenis der dynamische factor hier aanmerkelijk minder werd. In gevallen als de onderstaande kan de persoonsnaam het daarom gemakkelijk van de zaaknaam winnen, tengevolge van de daarbij optredende waarderingsnuance. Volgens de structuur van het onverzwakte actief-energetische werkwoord zou de zaaknaam hier natuurlijk subject hebben moeten zijn. Eng. $\mathrm{He}$ was told the truth. I was spared the trouble of zuriting; Hgd. Er war gefolgt von; de. han blev berövet sine penge ,ihm wurde sein Geld geraubt”; nedl. Ik werd opengedaan door mijnheer zelf. Ik werd door je neefje gezelschap gehouden. Zie ook hierboven pag. 120.

3. Dat op deze wijze ook heel wat van onze moderne europese verba activum tantum zijn geworden, juist zoals ook het „passieve” werkwoord dit in beginsel is, zal niemand verwonderen. Er was voor de theoretisch mogelijke passieve constructie eenvoudig geen aanknopingspunt aanwezig, en deze verviel dus als vanzelf. In het algemeen kan 
men zeggen, dat de dubbele genusvorm alléén dan voor de dag komt, als de aangeduide handeling duidelijk als centripetaal en dynamisch wordt gevoeld. In het andere geval heeft men uitsluitend het genus activum. Voorbeelden hiervoor zijn reeds bij een voorgaande gelegenheid gegeven (Med. Akad. v. Wet, A'dam, NR deel 3, No. 11, 12 vv.).

Het eindpunt van de gehele ontwikkeling wordt tenslotte bereikt in die gevallen, waarin bij de verbale betekenis in het geheel niet op de richting der aangeduide beweging wordt gelet. Het is, alsof deze onverschillig is. De dynamische factor is nu wel totaal verdwenen. Men heeft een actieve constructie, die echter evengoed - en vaak beter - in passieve zin kan worden verklaard. Eng. This cloth feels soft. The vessel steers with ease. Hgd. Es tanzt sich hier gut. Es sitzt sich dort angenehm. Fra. Ce tissu ne tache pas à l'eau. Les meilleures voitures graissent à la Kervoline, l'huile qui s'impose. Cela se porte beaucoup. Nedl. Wat zie jij toch bleek vandaag! Wat ze van die sollicitant vertellen, hoort goed. In het participiale gebruik zijn de omstandigheden voor het verdwijnen der dynamiek uiteraard nog gunstiger. De nuance is $\mathrm{nu}$ in werkelijkheid vaak totaal ongedifferentiëerd. Eng. The horses are putting to. The casinos are filling (passief); falling sickness; sleeping car; visiting day; walking stick etc. (neutraal); Hgd. dem in petto habendem Gedicht (Schiller); die vorhabende Reise; seine dabei hegende verräterische Absicht (Thümmel; passief); liegende Stellung; schwindelnde Höhe; bei nachtschlafender Zeit (neutraal); Fra. noble parure, pas trop voyante; séance tenante; argent comptant (passief); réunion payante; rue passante; café chantant (neutraal). Nedl. een uitslaande plaat; een stilzwïjgende voorwaarde; een zingende mis (mnl. lesende misse) (passief); een zittend leven; een staande receptie; de vallende ziekte (neutraal) ${ }^{172}$ ).

Eén conclusie kan men uit het bovenstaande zeker trekken. De term „passief” werkwoord is weinig gelukkig. Bij de aanduiding "passief” denkt ieder grammaticus, als onwillekeurig, aan het passieve genus (verbi energetici-activi). In zulk een combinatie betekent "passief” echter het volkomen tegendeel van ,actief”. En zo gaat men - hetgeen niet juist is - bij de aanduiding „passief” werkwoord precies hetzelfde denken. De tegenstellingen tussen de kategorieën worden daardoor onnodig verscherpt.

172) J. Wils, Vraag en Antwoord. Onze Taaltuin 7 (1938), 127 v. 
Men staat hier zeker voor een punt waarop ook de vertaaltechniek, die in de literatuur meestal wordt toegepast, het beschreven misverstand danig in de hand heeft gewerkt. Een vorm als maleis $k u$-pukul wordt b.v. gewoonlijk weergegeven met ,door-mij wordt-geslagen"; $k u$ panggil, kau-panggil „,door-mij (jou) wordt-geroepen” enz. Men ziet, hoe het nederlandse werkwoord hier in het ,passieve" genus staat. Inderdaad wordt door de constructie met door in de moderne europese talen een zekere zwakke actie van de agens uitgedrukt. We hebben dit zoëven reeds gezien (145 vv.). Het nadeel is alleen, het zij herhaald, dat door een dergelijke vertaling het ,passieve" werkwoordstype in een verkeerd daglicht wordt gesteld. Men halveert a.h.w. het dubbele genusstelsel van het nederlandse werkwoord; maakt abstractie van de ,actieve" helft daarvan, en verklaart dan de overblijvende rest tot een adaequaat voorbeeld van het ,passieve" werkwoordsgebruik uit de nietindo-europese talen. Men gaat in laatste instantie dus van de westerse taalstijl uit, om daaraan die van de oosterse taal te meten. Dit is methodologisch natuurlijk niet juist. Er ligt een ernstige begripsverwarring in een dergelijke techniek. De gevolgen daarvan in het theoretisch-taalkundig debat zijn dan ook niet uitgebleven. Wij van onze kant hebben daarom speciaal bij dit geval gebruik gemaakt van omschrijvingen, die zeker minder elegant waren, en soms zelfs regelrecht tegen het normale nederlandse taalgebruik ingingen, maar die anderzijds het voordeel hadden, althans ten dele de werkelijke aard der indonesische „passieve”, d.i. half-actieve constructie te benaderen. ( $k u$-pukul „vanwege-mij slaat-het-daar; kau-panggil ,door-jou dat-roepen-daar” enz.).

Wat de term ,passief” werkwoord aangaat, bestaat er echter zulk een uitweg niet. Men moet hier kiezen of delen. Een vervanging van de nu eenmaal ingeburgerde aanduiding is daarenboven moeilijk te vinden. Formuleringen als half-actief of gematigd-actief werkwoord missen aan vlotte hanteerbaarheid, wat ze aan grotere theoretische verkieslijkheid misschien bezitten. Het zijn eerder definities die men op deze wijze krijgt, dan benamingen. Het beste is daarom tenslotte wellicht om de oude term, die nu misschien ook wat duidelijker geworden is, toch maar te bewaren. Zo nodig kan men het woord „passief" ook nog tussen aanhalingstekens plaatsen of anders van het z.g. ,passieve” werkwoord spreken ${ }^{\mathbf{1 7 3}}$ ).

173) H. Vogt, Un aspect du problème actif-passif dans le verbe; Journal de psychologie normale et pathologique (1950), 130-138. 
HOOFDSTUK XIV.

\section{Het stelsel der flectietypen in het algemeen.}

We willen dit gedeelte van ons onderzoek beëindigen met enkele algemene opmerkingen, in de hoop ook op deze wijze nog het inzicht te kunnen verhelderen in het verschijnsel dat ons bezighoudt ${ }^{\mathbf{1 7 4}}$ ).

Daar is dan vooreerst de constatering, dat men met het flectietype blijkbaar één van de diepste kenmerken raakt, die er in een bepaalde taalkundige structuur maar te bereiken vallen. De taalwetenschap van het begin der negentiende eeuw heeft haar algemene taaltypologie vooral op de vorm en de graad van ontwikkeling der verbale flectie gebouwd. Men beseft thans meer dan ooit, welk een kern van waarheid er in deze methode schuilt. W. Schmidt heeft later op geheel andere gronden een aantal ,taalkringen” opgesteld, die de grenzen der genealogische taal,,families" geheel en al doorkruisen. Hij ging daarbij uit van het numerus, de nominale klassificatie, enz. ${ }^{175}$ ). Ook het flectietype is, naar het ons voorkomt, zeker een verschijnsel, dat voor een dergelijke mondiale comparatie in anmerking zou komen. Wie flectietype zegt, spreekt immers tegelijkertijd ook van casussysteem. Hij tast naar de verhouding van nomen en verbum, maar evenzeer naar de vrijheid der woordschikking. Hij betrapt de taal op een moment, dat ik en wereld in het nauwst denkbare contact tegelijkertijd met een en dezelfde vorm worden benoemd, maar de subjectieve kern zelf, het ik, en dus ook het pronominaal systeem, kan hij daarbij onmogelijk missen. Het is dus wel van belang, dat bij het toekomstig onderzoek speciaal ook op dit punt wordt gelet.

Daar is verder de gewichtige vraag naar de diepere aard van het verschijnsel der flectietypen zelf. Er bestaat in dit opzicht een merkwaardig verschil in opvatting tussen de comparatisten, dat weliswaar nooit openlijk als zodanig aan de orde is gesteld maar dat daarom niet minder van gewicht is. Schuchardt en Finck offerden duidelijk aan de geest van hun tijd, die typisch evolutionistisch georiënteerd was. Zij rangschikten de verschillende flectievormen daarom onmiddellijk na hun

174) J. Wils, De flectietypen in de verschillende talen der wereld. Leuvense Bijdragen 27 (1947), 73-89.

175) W. Schmidt, Die Sprachfamilien und Sprachenkreise der Erde, Heidelberg 1926. 
ontdekking in één monolineaire opklimmende reeks, en namen zonder nader bewijs aan dat een taal eerst de voorgaande phasen moest hebben doorlopen voordat de volgende tot realisering kon komen. Ook een zekere waarderingsgradatie was aan hun opvattingen niet vreemd. Zo lag voor Schuchardt het begin van alle wijsheid in het passieve werkwoord, maar voor Finck in de possessieve flectie. Voor beiden was echter het actief-energetische type met zijn zeer uitgebreid verbaal vormensysteem het eindpunt van alle ontwikkeling. Alleen C. C. Uhlenbeck was in dit verband voorzichtiger. Z.i. was de passieve constructie slechts ,voor een zekere phase van geestesontzerkkeling.... de voor-dehand-liggende en natuurlijke". We hebben op al deze punten reeds gewezen (74).

Wat is hier nu de juiste opvatting? Naar het ons voorkomt, dient men ook in dit geval weer een zekere middenpositie te kiezen. Men behoort zowel de Scylla van een ontijdig historisme als de Charybdis van een schijnbaar-absolute waarderingsscala te vermijden. We zouden m.a.w. op dit punt zonder voorbehoud de mening van Prof. C. C. Uhlenbeck willen volgen. Men kan de verschillende flectietypen het best als een serie "stilistische varianten” beschouwen ${ }^{176}$ ). De aangeduide werkelijkheid, de handeling die zich voltrekt, is in alle gevallen geheel dezelfde. Deze werkelijkheid vertoont echter allerlei aspecten en nuancen, en ieder volk doet voor zijn taalvorm daaruit nu weer een eigen en geheel onafhankelijke keuze. Voor de „possessieve” flectie domineert de gesloten totaliteit der situatie, de samenhang tussen ik en wereld, die juist op het moment van het handelen het meest innig en volkomen is. De energetisch-dynamische vorm daarentegen stelt de handeling duidelijk voor als een zeker bipolair proces. Het is de dynamiek, de druk die door het ik op de wereld wordt uitgeoefend, die nu voor de taalkundige aanduiding de doorslag geeft. En tussen deze beide uitersten staat het ,passieve” werkwoord (misschien het meest rijke type van de drie). De taalvorm is nu gebouwd op de levende, zich steeds ontwikkelende aanpassing die er bij het handelen tussen het ik en de wereld bestaat. En op géén der beide polen valt daarbij een bijzondere nadruk.

Naar men ziet, gaat de analyse, objectief gezien, in al deze gevallen

176) L. van Haecht, La pensée et le langage; Rapport Xth Int. Congress of Philosophy, A'dam 1948; 234 v.v.; Fritz Hintze, Zum Verhältnis der sprachlichen „Form” zur „Substanz"; Studia Linguistica 3 (1949), 86-105. 
dus volstrekt niet even ver. Men zou, in deze zin, van een zekere gradatie kunnen spreken. Zo hebben we zoëven b.v. op dergelijke gronden het ,passieve” werkwoord een plaats gegeven tussen het possessieve en het energetische type in. Historische betekenis in de zin van Schuchardt en Finck heeft een dergelijke ordening echter niet. Ook de gedachte aan een bepaald taalkundig ,plus" of "minus” is daaraan geheel vreemd. Men kan niet in enige absolute zin zeggen, dat een taaltype „stijgt” wanneer men zich daarin langzamerhand de persoonsflectie ziet ontwikkelen, zoals dit in een aantal noord-oostelijke kaukasustalen het geval is (lak, tabassaran etc.), en zoals zich dit ook in een bepaalde groep Bornutalen voordoet (musgu, barma, logone). Evenmin kan men op dezelfde wijze van een principiële ,daling” of ,achteruitgang” spreken, wanneer de oer-oude indo-europese persoonsconjugatie in een aantal moderne talen van West-Europa in verval geraakt of zelfs vrijwel geheel verdwenen is (engels, deens). De taalkundige kan in al dergelijke gevallen slechts, zuiver zakelijk, het verschil van taalkundig uitdrukkingstype constateren. Van een absolute historische localisering of van een absoluut waarderingsoordeel heeft hij zich echter geheel te onthouden, op straffe van anders de grenzen van zijn vak te overtreden.

Een derde punt betreft speciaal het actief-energetische type. Als onwillekeurig is dit hierboven als punt van uitgang gekozen; en de andere typen zijn, zeker in eerste instantie, gekarakteriseerd in zoverre zij daarvan afwijken. Zo is het vrijwel steeds geweest, de hele geschiedenis van het flectie-vraagstuk door. Historisch kan men een dergelijke gang van zaken zeker gemakkelijk begrijpen. Het energetisch-dynamische type is nu eenmaal het meest nabije, het meest bekende, en het sluit ook het meest aan bij de abstract-logische beschouwing die algemene en objectieve waarde schijnt te bezitten. Maar het is daarom des te meer zaak, er thans nog eens met nadruk aan te herinneren, dat de ingevoerde norm in werkelijkheid een zeker eindpunt voorstelt. $\mathrm{Er}$ loopt door het systeem der flectietypen een dubbele ontwikkelingslijn. Psychologisch gesproken neemt de objectivering van het ik en de wereld hoe langer hoe meer in scherpte toe. En taalkundig gezien, groeit volgens dezelfde evenredigheid bij de "hogere” typen ook de behoefte, om tevens uiterlijk en formeel aan te duiden hetgeen innerlijk wordt ervaren. De taalvorm wordt steeds meer tastbaar. Welnu, deze beide lijnen bereiken gelijktijdig hun hoogtepunt: juist in de actief- 
energetische flectievorm. Het taaltype, zoals b.v. de oudere indoeuropese talen dit vertonen, stelt evenzeer een wonder van denkkracht als van vormgeving voor. Evenwel, het bereiken van dit hoge niveau wordt met het verlies van een zekere vlotte natuurlijkheid duur betaald. De weg van het hoofd en het hart naar de lippen is wel bijzonder lang en gecompliceerd volgens de oorspronkelijke indo-europese stijl. Men stelt niet straffeloos regelmatig de wereld waarin men leeft voor als een zekere weerstand, en isoleert aldus het ik van zijn natuurlijk milieu. De uitzondering wordt niet zonder schade tot norm verklaard. En een rijk vormenstelsel, door onvermijdelijke uitzonderingen nog verder gecompliceerd, wordt spoedig tot last, zoals Steinthal reeds gezien heeft. In de taaltypen met possessieve of passieve flectie staat men m.a.w. zeker niet minder dicht bij de werkelijkheid dan dit bij de energetischdynamische flectie het geval is. Integendeel, de beoordeling der situatie en de vormgeving beide zijn hier veel zakelijker en meer gezond en natuurlijk. Een vervalperiode of een breuk in het systeem, zoals in de indo-europese talen vrij snel is opgetreden, valt hier zo lang de verhoudingen zuiver blijven, zeker niet zo spoedig te verwachten.

Tenslotte moge nog een schematisch overzicht van de verschillende flectietypen volgen, dat thans ook zonder nader commentaar wel duidelijk zal zijn. 


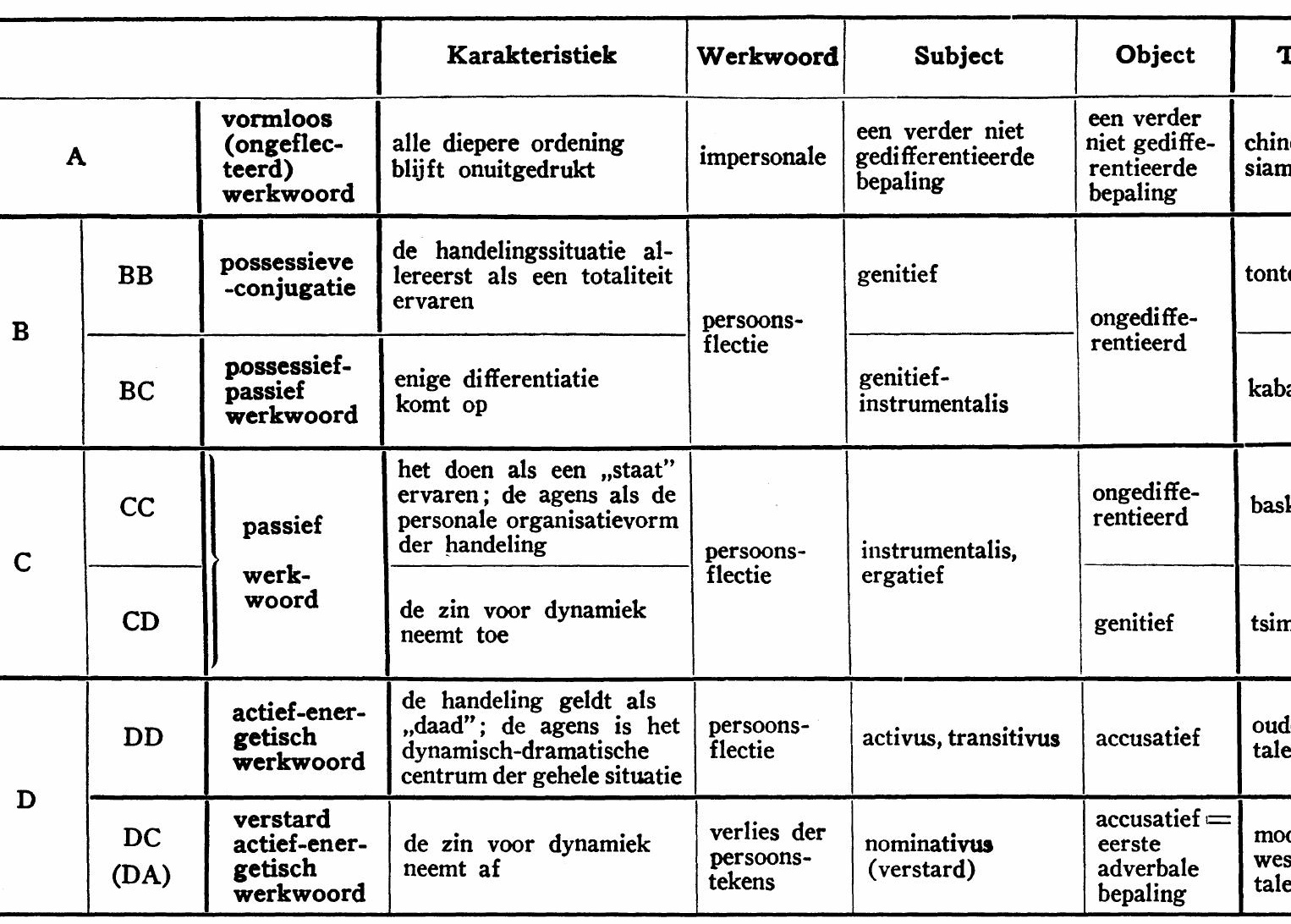




\title{
VIERDE DEEL.
}

\section{HET VERBALE SYSTEEM DER INDONESISCHE TALEN.}

\author{
HOOFDSTUK XV.
}

\section{„Activisme” en "passivisme".}

Zo zijn wij thans dus weer op hetzelfde punt aangeland, dat we in de loop van deze studie reeds tweemaal verlaten hebben: de taalkaart der indonesische conjugatie die dringend om een nadere verklaring vraagt. De omweg die we de laatste maal hebben gemaakt, is zeer zeker lang geweest. Van allerlei kanten is vergelijkingsmateriaal bijeengebracht, en op bepaalde theoretische kwesties zijn we diep ingegaan. Voor de nodige verheldering der begrippen was dit echter onvermijdelijk.

Het voornaamste resultaat voor ons doel is zonder twijfel, dat er géén reden is om aan het possessieve werkwoord het praedicaat „flectie” te weigeren. De vorm der ,flectie” is hier primitief, zeer zeker; deze is vrijwel de meest primitieve van het gehele stelsel dat we hebben geanalyseerd, maar ,flectie” is het wat men hier vindt. Men overdrijft niet met te zeggen, dat het aspect van het indonesische flectievraagstuk door dit nieuwe gezichtspunt totaal van karakter verandert. Hier ligt de grote wending t.o.v. de vroegere zienswijze. Allereerst wordt het nu immers duidelijk, dat de flectievorm van niet minder dan de oertaal zelve, morphologisch beschouwd, reeds van het ,possessieve” type was. We hebben dit feit hierboven al geconstateerd (13), maar begrijpen nu pas dat het niets anders dan een onbewuste inslag van ,activistische" princiepen geweest is, die hier steeds Fr. Müller's ,praedicatief” flectietype naar voren deed schuiven. De etymologieën der persoonstekens van het type $*_{k u}<a k u$; $*_{m u}<k a m u$ enz. zijn niet alleen 
zakelijk onjuist, ze gaan in de grond ook uit van een valse theoretische grondslag.

Tengevolge van deze nieuwe opvatting stijgt nu ook aanmerkelijk het aantal talen, dat in de beschouwingen moet worden opgenomen, omdat het flectieverschijnselen vertoont. In tegenstelling met de vroegere gedachtengang kan men zeggen, dat de indonesische talen niet enige verspreide sporen maar, juist omgekeerd, een uitbundige overvloed van flectievormen en -typen vertonen. Er zijn zelfs talen, die naast het meest gebruikelijke flectietype nog resten van twee of drie andere typen blijken te bezitten, die eveneens in de taal min of meer regelmatig voorkomen. Zulk een overmaat is zeker zeldzaam in de talenwereld! En de vraag is nu maar, welke de verhouding van al deze typen is, en hoe deze in het volle indonesische verband beschouwd, in één groot stelsel kunnen worden samengevat.

Als tweede punt mag misschien een zekere verdieping van het begrip "passief werkwoord" genoemd worden. We hebben de verschillende morphologische en psychologische kenmerken die daarvan reeds bekend waren, nader kunnen ontleden en tot één beeld samenvatten, dat volkomen redelijk en logisch bleek te zijn. Dit-is een zaak van groot gewicht, omdat daarmede voor het eerst in de geschiedenis van het indonesische flectiedebat een zeker platform geschapen is, waarop de „passivisten” en de ,activisten” elkander nu werkelijk op de basis der feiten kunnen ontmoeten. Totnutoe had - hoe vreemd dit ook moge lijken - een dergelijke mogelijkheid niet bestaan (79).

Hoe gewichtig het is in dit verband over goede begrippen te beschikken blijkt b.v. onmiddellijk reeds hieruit, dat men op grond daarvan in staat is bepaalde aanvallen op het „passieve” werkwoord ineens en voorgoed af te wijzen, eenvoudig omdat deze op een vals begrip blijken te berusten. Men kan nu eenmaal niet weerleggen, wat men in de grond niet kent. Men overdrijft niet met te zeggen, dat een goed deel van de ,activistische" reactie in indonesische vakkringen heeft berust op een misverstand aangaande het omstreden punt. We hebben hierboven reeds over het werk van Tendeloo en over de dubbelzinnigheid van de term ,passief" gesproken $(79,138)$. Op andere dergelijke gevallen komen we hierachter nog nader terug.

Het eigenlijke beslissende argument voor de „passieve” opvatting, dat wij zullen hebben aan te voeren, zal echter niet enkel negatief 
kunnen zijn. We zullen positief en concreet moeten aantonen, hoe de verschillende kleine en grote moeilijkheden, die de indonesische conjugatiekaart biedt, en die we in onze inleiding uitvoerig hebben aangeduid, alle zonder bezwaar kunnen worden opgelost, wanneer men van het beschreven „passieve” werkwoordstype uitgaat. Dit is de niet gemakkelijke, maar in ieder geval zeer concrete taak, waarvoor wij ons bij het nog resterende deel van het onderzoek zien gesteld. Welke daarbij onze werkwijze zal moeten zijn, volgt uit het voorgaande vanzelf. Wij zullen moeten laten zien, hoe de te analyseren verbale ontwikkeling der indonesische talen een volkomen parallel biedt van de nominale ontwikkeling, die in het tweede deel van onze studie reeds beschreven is. Naast de groei van de genitief zullen we ook die van het nieuwe begrip "subject”, en dus ook die van het nieuwe type „conjugatie”, zich moeten zien voltrekken. Juist door dit voortdurend parallellisme staat de bewijsvoering sterk, en wordt het inzicht in de werkelijke gang van zaken volledig. We bespreken dus eerst de enkele flectieloze typen, die op het indonesische terrein hier en daar nog zijn achtergebleven, en werken daarna in oost-westelijke richting voort. Aan de lezer blijft dan tenslotte het oordeel, of aan de gestelde opgave is voldaan of niet.

\section{HOOFDSTUK XVI.}

\section{Het ongeflecteerde werkwoord.}

Voorzover de gegevens reiken vindt men enigszins zekere sporen van het ongeconjugeerde of vormeloze werkwoord in de indonesische talen alleen in het sawoe, ngad'a (Flores), sobojo (Taliabo, Soelagroep), buru (Màserète), de tidongdialecten van Borneo, het yami (philippijnse ondergroep). En ook in deze talen komen naast het oorspronkelijke type telkens ook nog tekenen van verdere ontwikkeling voor. Men staat hier dus duidelijk voor een zeker uitzonderingsgeval. Buru jàko iko ,ik ga”; kai iko ,jij gaat”; rine iko „hij gaat”; kami iko „wij gaan”; kimi iko ,gij gaat”; sira iko ,zij gaan”.

Vooral het ngad'a laat zien, hoe vaag de aanduiding van de verbale handeling wel is bij het vormeloze werkwoord. Dit is nu weinig meer dan een impersonale. Er wordt alleen uitgedrukt (en dit nog uiterst 
vaag), dat er een zekere betrekking bestaat tussen het subject en het praedicaat. Van welke aard deze is, blijft echter geheel in het duister. Ook de subjectskategorie wordt hier alleen gekenmerkt door haar speciale plaats in de zin, nl. vlak vóór het praedicaat. Verdere morphologische kenmerken zijn er niet. Vandaar dat Arndt b.v. een hele serie gevallen kan noemen, waarin eenzelfde vorm nu weer eens de passieve en dan weer de actieve nuance weergeeft. In andere voorbeelden wisselen ook het transitieve, het intransitieve en het reflexieve gebruik. Teka dzata „ein Spinnrad verkaufen”; dzata kěnana teka ya „das Spinnrad ist schon verkauft". Zico cana "ein Kind waschen, baden"; go cana da zico „das Kind wäscht, badet sich”, go cana da zico ya ,das Kind ist (hat sich) gewaschen". Micu tau go capa vi dicana ,was tut ihr hier?". Manu ceko zuca kĕnana sě ceko da cate meze, vi tau radza „einer von den beiden Hähnen war so stolz, dass er König werden wollte" ( $\tan$ „tun”, resp. „werden”) ${ }^{177}$ ).

$\mathrm{Bij}$ de pronominale subjecten, die aan het werkwoord kunnen worden toegevoegd, vindt men hetzelfde gemis aan scherpe grenslijnen terug. Het is voorzeker geen toeval, dat zowel het sawoe, als het ngad'a en het sobojo géén onderscheid kennen tussen het personale en het possessivum. Eenzelfde vorm doet in beide functies dienst ${ }^{178}$ ). Ook hier wordt dus in werkelijkheid weer niets anders anngeduid dan een bepaalde „personale sfeer”, het psychologische zo zijn, juist zoals we dat hierboven bij de possessieve flectie hebben gezien (130). In de tidongdialecten wordt het possessivum uit het personale afgeleid door achtervoeging van yampunan (Tarakan), resp. simpunya (Bolongan) ${ }^{\mathbf{1 7 9}}$ ). Een dergelijke suffigering zal wel secundair zijn (cfr. maleis punya „eigenaar zijn van”). Ook hier schemert het vroegere gemis aan differentiatie dus nog door de huidige meer gecompliceerde toestand heen. Sobojo aku lau (a lau) ,bij-mij daar-loopt-het”, juist zoals $a k u$ ina „bij-mij die-moeder" = mijn moeder; Bolongan rumah aku „het-huis daar-bij-mij" (= mijn huis) naast aku dibai ,bij-mij daar-gaat-het-naarbeneden" ( $=$ ik daal af $)$.

177) P. P. Arndt, Grammatik der Ngad'a-Sprache, VBG 72, 3, 18 v.

178) Andere opvatting voor het sawoe bij H. Kern, Sawuneesche Bijdragen (= Verspreide Geschriften 6, 192) ; J. K. Wijngaarden, Sawuneesche Woordenlijst, 's Hage 1896.

179) Merwyn W. H. Beech, The tidongdialects of Borneo, Oxford 1908, 27. 
De tekenen van beginnende conjugatie, die de thans besproken talen vertonen, zijn zéér karakteristiek. Duidelijk verraden ze de richting, welke de ontwikkeling inslaat. Zo voegen zowel de tidongdialecten als het sobojo en het ngad'a soms speciaal het persoonsteken toe in de imperatief. In dit geval tracht de spreker uitdrukkelijk de handelingsdynamiek bij zijn hoorder op te wekken. Het gebruik van een meer expliciete vorm is hier dus volkomen begrijpelijk. Tidong mindau-mu s'ndagitu ,go down now"; tinak-mu gitu da Iran ,give it to Iran"; sinainal-mu ulin ,hold the rudder". Ook in andere tidongvoorbeelden buiten de tweede persoon, die door Beech worden vermeld, schijnt steeds een speciale subjectief-dynamische nuance de toevoeging van het persoonsteken te hebben uitgelokt. Guang-ku malang „I want to sleep”; lasu nia! guang-ku m'njeu ,it is so hot! I must bath"; jinareab-mu? „can't you answer?" nusaï tinugus-na? „what has he done?" ${ }^{180}$ ).

Niet minder typisch zijn de gevallen van prenasalering, die in deze talen voorkomen. Men kent dit verschijnsel, en weet dat het een zekere intensifiëring van de verbale betekenis uitdrukt. „De versterkte stam”, zo verklaart Dr. Adriani in zijn fraaie studie hierover, ,stelt (de handeling) voor.... als met meer kracht, ijver en inspanning geschiedende dan de niet-sterke (zwakke) stam dit doet" ${ }^{181}$ ). Men kan in de prenasalering overigens twee phasen of trappen onderscheiden. In de eerste phase wordt het nasale element eenvoudig aan de stam geprefigeerd, in de tweede wordt de samenhang zo innig dat de stamanlaut geheel verdrongen wordt.

In de tidongdialecten gaat de door Dr. Adriani gegeven karakteristiek in ieder geval geheel op. De prenasalering komt hier nl. uitsluitend voor bij de transitiva, dat wil dus zeggen juist in die gevallen, waar de verbale dynamiek bijzonder aanschouwelijk wordt, omdat nu ook nog een andere grootheid buiten het subject daarbij betrokken is. De intransitiva prenasaleren nooit. Nga-n-tugus "to work”; nga-m-badi ,to abuse"; nga-ñ-choba ,to try" (eerste phase); mumpas (<m-pumpas) „to enter"; ngirim ( $<$ n-kirim) ,to send" (tweede phase). Maar tudong „to sit"; kindi ,to stand".

In het sobojo is de prenasalering speciaal thuis in de vetatief van

180) Merwyn W. H. Beech, The tidongdialects of Borneo, 27, 42; cfr. Appendix bij Dr. A. A. Fokker, 119.

181) N. Adriani, De intensieve of activiteitsvormen in eenige talen van Indonesië, VMAWA 4e reeks, deel $10,31$. 
„vele werkwoorden" 182) (tweede en derde persoon enkel- en meervoud). Dat is dus de plaats, waar eveneens in de andere talen van hetzelfde type, de persoonsconjugatie begint te ontstaan. Men kan zich ook deze laatste samenhang zeer goed begrijpen. Het persoonsteken begint toegevoegd te worden, zo zagen we al herhaaldelijk, in de gevallen van een bijzondere emphase. Dan, maar dan ook alleen, gelukt het voorlopig aan de taal de grote sprong naar het flecterende type te maken. Deze zelfde sfeer is het nu echter ook, die de beste voedingsbodem vormt voor de prenasalering, zo vernamen we van Dr. Adriani. De coincidentie van de beide verschijnselen is dus niet toevallig. Dele guke ntalinga ,peuter (kuke) niet in je oor”; dele baling „,keer niet terug (paling)"; dele duli aku „duw (suli) me niet”.

Van veel belang voor ons doel is verder, dat de prenasalering in het sobojo eveneens regelmatig wordt toegepast bij het nomen rectum van een nominale constructie. Ook deze overeenstemming zal wel niet op toeval berusten. We zullen daaruit mogen afleiden, dat ook de verbale verbinding in het sobojo in genitivische zin behoort opgevat te worden. Zo b.v. kabang „,schild”; toeka ,,buik” maar als nomen rectum ñ-kabang; $n$-toeka enz. Bij possessieve pronominale constructies komt hetzelfde voor, althans in de tweede en derde persoon enkel- en meervoud; akoe (kita) ina ,mijn (onze, incl.) moeder" maar kou n-ina ,jouw moeder".

Blijft de aard der groeiende verbale constructie in het sobojo misschien nog enigszins onzeker, in het ngad'a wordt elke twijfel in dit opzicht in ieder geval opgeheven. Het persoonspronomen wordt hier nl. uitdrukkelijk met tussenschakeling van het genitiefteken go aan de stam gesuffigeerd. De flectievorm die aldus ontstaat, is derhalve duidelijk genitivisch, „possessief” van aard. Ook nu treedt overigens weer prenasalering op. De nasaal wordt daarbij echter niet aan de verbale stam toegevoegd, maar aan het pronomen. Over dit verschil met wat we in het sobojo hebben gezien, behoeven we ons niet te verbazen. In werkelijkheid hoort het nasale element met zijn intensifiërende en verbindende functie immers bij de verbale constructie als geheel. En of dit dus practisch aan het eerste of aan het tweede lid wordt toegevoegd, is in de grond onverschillig. Kau "du" maar lä̈ go gau ,gehe nur, mach dich fort!"; kita (kami) „wir" maar lä̈ go gita (gami) ,gehen wir, laszt uns gehen " $\left.{ }^{183}\right)$.

182) J. Fortgens, Bijdrage tot de kennis van het sobojo 22 .

183) P. P. Arndt, Grammatik der Ngad'a-Sprache 38 vv. 
HOOFDSTUK XVII.

\section{Het „passieve” werkwoord.}

De voorgaande ontwikkelingen hebben ons reeds op de drempel gebracht van de verbale flectie, één van de meest opvallende trekken, naar men weet, waardoor de indonesische talen van hun austronesische oerverwanten verschillen. Overal over het gehele uitgestrekte gebied zijn de nieuwe vormingen zichtbaar. Telkens en telkens is weer de uiterlijke gedaante verschillend, maar de geest die daaruit spreekt, blijft volkomen gelijk. Deze laatste bewering zal wellicht diegenen onder onze lezers enigszins vreemd voorkomen die zich herinneren, wat hierboven over de grilligheid der indonesische taalkaart op dit punt in het midden is gebracht. En toch is onze mening ten volle verantwoord, naar het ons toeschijnt. En hoe meer men daarover nadenkt, hoe duidelijker het oordeel wordt. De kwestie is alleen maar eerst het standpunt te vinden, van waaruit de onmiddellijk sprekende, feitelijke verscheidenheid als een eenheid kan worden overzien en begrepen.

Hoe immers komt de verbale flectie in de indonesische talen tot stand? $\mathrm{Er}$ is slechts één punt waaraan men zich hier kan vasthouden, nl. de aard der gebruikte persoonselementen, zoals die door Prof. Jonker zijn gereconstrueerd. Dit ene punt nu is echter ook volkomen voldoende. We hebben de zeer speciale functie der elementen $* k u ; * m u$; *na reeds uitvoerig leren kennen (19 vv.). We weten, dat deze bij de nomina weergaven, of de daardoor aangeduide zaken naar de inheemse opvatting tot de persoon van het subject gerekend konden worden (= inalienabel), of niet (= alienabel). Het psychologische $z o$ zijn gaf hier de doorslag. Blijkbaar moet deze zelfde distinctie dus ook, minstens aanvankelijk, bij de indonesische verba hebben gegolden. Anders zou de overgang op dit punt zeker niet zo gemakkelijk zijn geweest. Ook de verbale handeling moet hier dus oorspronkelijk slechts als een zeker $z o$ zijn, als een bepaalde "staat" zijn opgevat, en niet als een „daad”. De agens moet niet als het dynamisch-centrifugale middelpunt der situatie zijn aangeduid, maar enkel als ,op een bepaalde wijze betrokken en ingeschakeld in het betreffende verband". Het is m.a.w. niet het actief-energetische verbale type waarvoor men hier staat, maar het veel minder toegespitste type van het z.g. „passieve” werkwoord.

Alleen één punt dient daaraan nog toegevoegd, wat de herkomst der 
morphologische tekens aangaat. Deze laatste zijn „possessief” van aard, zo hebben we gezien ( 9 vv.). En zo komt hier dus bij slot van rekening de typische dubbelvorm tot stand, die we hierboven in de tabel met BC hebben aangeduid (153). Het indonesische werkwoord drukt zijn passiviteit met behulp van oorspronkelijk possessieve elementen uit. Welke van de genoemde karaktertrekken het diepste is, is zonder meer duidelijk: de passieve. Het possessieve element betreft enkel de uiterlijke vorm. En na eenmaal aan de historische reconstructie der tekens de eer te hebben gegeven die daaraan toekomt, kunnen we dus verder, ter vermijding van omslachtige aanduidingen, gevoegelijk kort samenvattend zeggen, dat het indonesische werkwoord "passief" van karakter is.

Ook voor het corresponderende stelsel der nominale casus heeft de hier verdedigde opvatting uiteraard belangrijke consequenties. En wat van niet minder gewicht is - evenals in het voorgaande geval zullen we juist daaraan onze werkmethode in het volgend deel van het hoofdstuk kunnen ontlenen. We hebben immers hierboven reeds gezien, hoe zich uit de oppositie tussen de alienabile en de inalienabile kategorieën in de verder ontwikkelde indonesische talen een ,genitief”, een gewoon type van nominale casus dus, heeft ontwikkeld. Welnu, dit gehele proces dat we tot in bijzonderheden hebben gevolgd ( 32 vv.; 59 vv.), vormt naar thans blijkt, in werkelijkheid slechts een deel van de gehele ontwikkelingsgang. Er is hier nog veel meer gebeurd. De geleidelijke constitutie van een nominale genitief heeft een volkomen corresponderende tegenhanger gehad in die van een zekere subjectsnaamval, en wel in die van een ergatief of een instrumentalis, zoals de structuur van het ,passieve" werkwoord nu eenmaal eiste. En juist zoals bij de nomina elk van de oorspronkelijke kategorieën het uitgangspunt kon vormen voor de nieuwe ,genitief", zo is juist ditzelfde ook bij de verba met de instrumentalis het geval geweest. De gang van het gehele proces was dus vrij ingewikkeld. Uit de dubbele oppositie ,alienabel” : ,,inalienabel” groeide ook een dubbel casussysteem. En ging het over een pronominaal subject, dan groeide het nieuwe teken vast aan de verbale stam, en ontstond dus wat men in de taalwetenschap gewoon is een "flectie” te noemen.

Men kan in het geval van de subjectsbepaling globaal de volgende structuurlijnen onderscheiden, die we hierachter stuk voor stuk zullen nagaan, en waarvan ieder onmiddellijk de parallel met de reeds beschreven ontwikkeling van de genitief zal inzien.

Verh. dl. XII. 
$1^{\circ}$. Juist zoals de inalienabile possessie naar oeroude austronesische gewoonte achter aan het nomen werd uitgedrukt, maar de alienabile possessie vóór aan het nomen, zo ontstonden o.i. in het oer-indonesisch ook twee flectietypen tegelijk: een proclitisch (prefigerend) type en een enclitisch (suffigerend) type ${ }^{184}$ ).

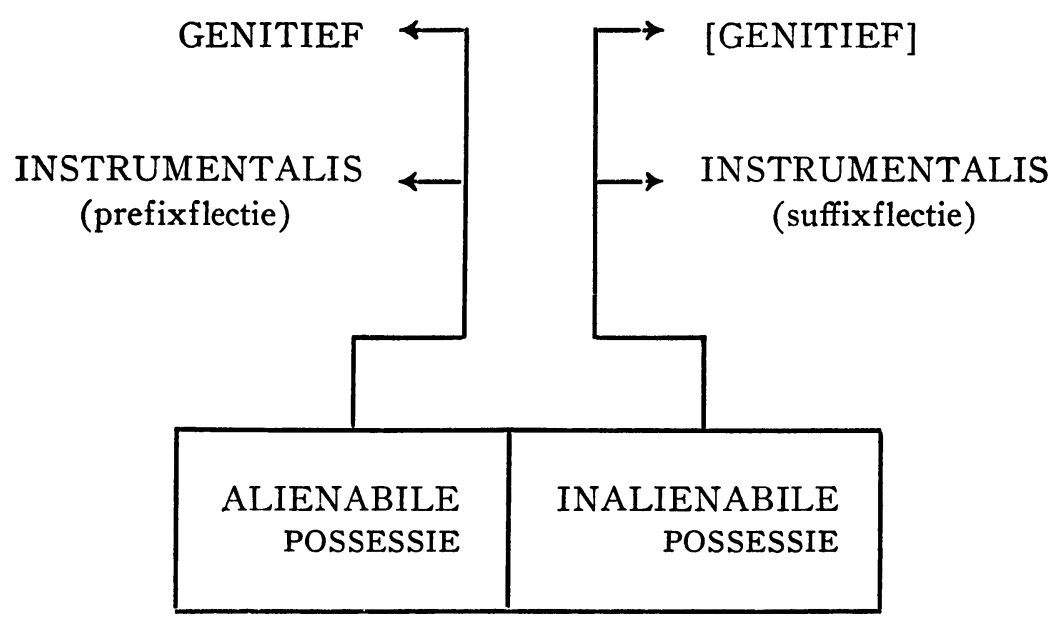

$2^{\circ}$. Oorspronkelijk stonden de proclitische en de enclitische flectietypen volkomen gelijk. Juist als bij het nomen kwam later echter ook hier de gunstigste plaats te liggen vóór de stam. Naarmate de drang naar het uitdrukken der dynamiek stijgt, spreekt de voorkeur voor de proclise sterker. Vandaar dat men in veel gevallen secundair de enclitische flectie ziet ineenschrompelen en zelfs verdwijnen. Soms ook gaan achteraf de enclitische typen in proclitische over.

$3^{\circ}$. Juist zoals bij de constitutie van de genitief de oeroude possessieve tekens $*_{k u} ; *_{m u} ; *_{n a}$ enz. hoe langer hoe meer door de corresponderende versterkte personale tekens opzij worden gedrongen, zo heeft dit ook bij de persoonstekens der zich ontwikkelende flectie plaats. Men kan dit proces zowel vóór als achter de stam volgen, maar

184) Voor de mening van Prof. Jonker aangaande deze beide flectietypen, zie hierachter 165. Haaksma laat zich nergens met beslistheid uit over dit punt. Uit zijn bespreking van het kupang krijgt men echter de indruk dat de suffixconjugatie z.i. is ontstaan uit een ouder conjugatietype met prefixen en suffixen tegelijk. Inleiding 132. 
natuurlijk vooral vóór, omdat voor de taal in de vervanging door een personale één van de sterkste middelen gelegen is om aan de steeds stijgende drang naar dynamiek uiting en gevolg te geven.

\section{A. De oostelijke talen.}

a. De verhouding van de enclitische en de proclitische flectietypen.

De prefixflectie en de suffixflectie van de indonesische talen zijn van volkomen gelijke oorsprong, zo hebben we zojuist gepostuleerd. Dit wil echter niet zeggen, dat deze beide typen nu daarom ook geheel van gelijke aard zijn. Het tegendeel is waar. De verdedigde theorie eist dat de suffixflectie op de één of andere manier nog een zeker inalienabel stempel zal dragen, maar de prefixflectie een alienabel stempel, hoe men deze laatste termen dan ook precies verstaat.

Welnu, deze verwachting die eenvoudig op de theoretische redenering gebaseerd is, wordt door de practische inductie niet beschaamd. Integendeel! In de Ambon-Timorgroep, in de groep dus waar men de oorspronkelijke oer-indonesische verhoudingen op dit punt nog het zuiverst beoordelen kan, vindt men onmiddellijk het beschreven onderscheid op karakteristieke wijze terug. Zo vermeldt b.v. Stresemann voor het paulohidialect op Seran, dat hier speciaal de „mediale” verba hun persoonsteken suffigeren. Practisch worden hiermee bedoeld, zoals uit de gegeven voorbeelden blijkt, de verba die een zeker $z o-z i j n$ uitdrukken, die op lichamelijke feiten wijzen, en verder de verba reflexiva. Maar de verba die een object bij zich hebben, de transitiva dus, prefigeren even regelmatig ${ }^{\mathbf{1 8 5}}$ ). Tauern heeft later juist dezelfde constellatie ook bij andere serandialecten teruggevonden ${ }^{186}$ ).

Men ziet dus, hoe de begrippen ,inalienabel” en ,alienabel” hier in de verbale sfeer zijn gereïnterpreteerd. Uit het eerste is ongeveer „mediaal”, ,intransitief” of ,centripetaal” ontstaan, maar het tweede is met „transitief” of ,centrifugaal” gelijkgesteld. De overgang is zeker plausibel, en we zullen daarvan in de hierna te bespreken talen nog herhaaldelijk meer voorbeelden zien. Zo zijn b.v. suffigerende verba in het paulohi typen als piri- „müde sein”; sisi- „kahl sein”; alae-

185) E. Stresemann, Die Paulohisprache, 's Hage 1918; 18, 26 vv.

186) O. Tauern, Beitrag zur Kenntniss der Sprachen und Dialecte von Seran, Anthropos 23 (1928), 1000-20; 24 (1929), 953-81; 25 (1930), 567-78; 26 (1931), 109-39. 
„,heiser sein”; amalae- „Durst haben”; hirisue- „Schüttelfrost haben”; amamuae- „gähnen”; sikae- „sich fürchten”; paleae- „sich freuen”; faita- ,, sich still verhalten”; pei- ,(selbst) anbrennen, verbrennen” maar -pei „(etwas) anbrennen”; $u$-kosa manue terur-i ,ich zerbreche das Ei" maar manue terur-i kosa-e ,das Ei zerbricht" enz. In het Wemaledialect zijn reeds een antal intransitiva naar de groep der centrifugalia overgeheveld. $\mathrm{Zij}$ prefigeren dus de persoonstekens. Hier wordt trouwens, evenals in het Makabaladialect, soms ook het persoonsprefix versterkt door de toevoeging van het zelfstandige personale. Ook dit is een belangrijke innovatie (derde ontwikkelingslijn). In het paulohi en het Lissabatadialect komt een dergelijke versterking alleen voor in het geval dat er bijzondere nadruk wordt gelegd.

In het boeli van Zuid-Halmahera is de samenhang tussen het nominale en het verbale flectiestelsel misschien nog duidelijker dan in de serandialecten. Juist zoals men hier b.v. heeft in een geval van inalienabile possessie ja boboko-k; a boboko-m; $i$-boboko ,mijn (jouw, zijn) hoofd" enz., zo luidt het ook bij een werkwoord als oelo lolo „houden van” (oelo ,gewillig”; lolo, cfr. mal. dalam) achtereenvolgens ja oelo-k lolo; a oelo-m lolo; $i$ oelo lolo ,ik (jij, hij) houd(t) ervan" enz. En naast een alienabel voorbeeld als $j a-n i-k$ ebai; $a-n i-m$ ebai; $i-n i$ ebai „mijn (jouw, zijn) huis” waarin $n i$ als ,possessive” optreedt, staat bij de verba b.v. onmiddellijk een vorm als $l e$,hater": $j a-n i-k l e$; $a-n i-m l e$; $i-n i l e$, ik (jij, hij) haat" enz. De verhouding van de proclitische en de enclitische flectie valt hier echter niet met zekerheid te bepalen, uit gebrek aan gegevens. Dr. Adriani vermeldt dat „werkwoorden, die gevoelens van het hart uitdrukken" speciaal de persoonstekens suffigeren ${ }^{187}$ ). Dit is dus in ieder geval juist als in de serandialecten.

De reden, waarom juist de serandialecten en het boeli zo scherp de beginphasen der indonesische flectie zijn blijven weerspiegelen, is niet moeilijk te vinden ${ }^{\mathbf{1 8 8}}$ ). De distinctie tussen de alienabile en inalienabile possessie is hier nog grotendeels virulent gebleven, en daarom kan

187) N. Adriani, De Bare'e-sprekende Toradja's van Midden-Celebes III, 330 vv.; 321 vv.

188) In het ambonees komt nog een suffixflectie voor bij enkele verba denominativa, die speciaal een physieke toestand aanduiden; Asiloeloe: au letasele-ku „ik heb dorst”; Saparoea: hau amalae-u ,id.” Ook het kupang kent nog het gebruik van enclitische tekens als verbale subjectsexponent. Bij welke verba dergelijke tekens gebruikt worden, is echter niet bekend. 
precies hetzelfde ook gezegd worden van de verbale verschijnselen die zich daarbij onmiddellijk aansluiten. Andere Ambon-Timortalen getuigen echter van een nieuwere stijl. De nieuwe genitiefkategorie breekt zich hier baan, dwars door de oude deellijnen heen. En ook nu blijven de verbale en de nominale ontwikkeling door één rythme gedragen. Ook de subjectskategorie verandert totaal van karakter. Enkele van deze gevallen zijn reeds uitvoerig onderzocht, ze behoren tot de meest geciteerde voorbeelden uit de literatuur over de verbale flectie. Het is daarom wel het beste, dat we deze ook taal voor taal behandelen.

\section{a) Het rottinees.}

Daar is dan vooreerst het rottinees, de taal van een klein eiland ten westen van Timor, die door de beide monumentale boeken van Prof. Jonker en de zich daarbij aansluitende studies tot de best onderzochte van de gehele archipel is gaan behoren ${ }^{189}$ ). Hoe is nu het beeld der flectie in deze taal? Er zijn niet minder dan drie typen, die hier in aanmerking komen, en de eerste indruk is dus zeker vrij complex. Toch heeft elke lijn van het gevormde systeem, ja zelfs elk onderdeel daarvan, naar zal blijken, diepe zin en betekenis.

$1^{\circ}$. Daar is in de eerste plaats in het rottinees een zekere suffixconjugatie, die echter alleen bij enkele tientallen van verba voorkomt. Jonker heeft deze in zijn grammatica reeds volledig afgedrukt (449), en het is daarom onnodig deze opnieuw te citeren. Het zijn uitsluitend verba van $z o-z i j n, z o-w o r d e n$, lichamelijke reacties, intransitiva etc. die hier genoemd worden. Men herkent daarin gemakkelijk dezelfde kategorieën, die ook in het boeli en in de serandialecten reeds suffixaal werden vervoegd. Het inalienabel-nominale begrip kan natuurlijk bijzonder gemakkelijk in het intransitieve worden omgezet.

Alleen het gebruikte tekenstelsel zou ons misschien een ogenblik kunnen doen aarzelen met de voorgestelde typologische identificatie. Als agensaanduiding voor de rottinese suffixconjugatie worden nl. niet de possessieve elementen gebruikt, zoals in het boeli en in de dialecten van Seran, maar de personalia, voorafgegaan door een nasaal element.

189) J. Jonker, Bijdrage tot de kennis van de rottineesche tongvallen, BTLV 68 (1913), 521 vv.; -, Rottineesch-Hollandsch Woordenboek, 's Hage 1908; Rottineesche teksten met vertaling, ibid 1911; -, Rottineesche Spraakkunst, ibid 1915. 
Hoe valt dit te verklaren? Men heeft b.v. dè mata-n ana ,en hij stierf”; tè ta mata- $\dot{n}-\grave{o} f a$ „,maar gij zult niet sterven". $\mathrm{Nu}$ is de vervanging van de possessieve elementen door de corresponderende personalia geheel volgens de hierboven gegeven derde ontwikkelingsregel. Deze geeft dus geen moeite. Wat valt er echter van het nasale tussenzetsel te denken? We zouden daarin niets anders willen zien dan hetzelfde element, dat in talen van ongeveer gelijke ontwikkelingshoogte (b.v. bada, napoe) als genitiefteken voorkomt, en dat we hierboven ook reeds in het sobojo en het ngad'a hebben aangetroffen (158). De oorspronkelijke functie ervan is tegelijk deictisch en verbindend. We treffen hier m.a.w. opnieuw een voorbeeld aan van een verschijnsel, dat zich bij de taalontwikkeling herhaaldelijk voordoet, en dat we hierboven eveneens reeds hebben gezien. De taal gaat op dergelijke momenten niet met sprongen vooruit. De nieuwe aanduidingswijze komt niet ineens tot stand. Voorlopig blijft als overgangsphase nog een zekere dubbelheid bestaan. De taal neemt a.h.w. met de ene hand weer terug wat ze met de andere heeft gegeven. Zo werd nu ook hier het oude possessieve teken wel door het personale vervangen, maar het personale wordt tegelijkertijd door de toegevoegde nasaal weer half in een possessief element terugveranderd! Zo wordt de nodige continuiteit toch bewaard.

In de eerste en tweede persoon luidt het gebruikte tussenzetsel intussen niet eenvoudig $n$ maar $\dot{n}$. Er is hier dus een gutturaal element toegevoegd, en wel duidelijk $-k$, het oorspronkelijke inalienabile teken van de eerste persoon singularis. We weten immers reeds hoe in het rottinees juist dit teken secundair bij de inalienabile kategorie veralgemeend is ( $56 \mathrm{v}$.). Bij de suffixflectie heeft dus op dit punt juist hetzelfde plaats gehad, als wat bij de nomina is geschied. Men ziet hieruit opnieuw, hoe nauw de verbale en de nominale ontwikkeling in de Ambon-Timorgroep bij elkaar aansluiten. Tot in de deviaties van het systeem reikt het parallellisme! Een vorm als mata- $\dot{n}-\grave{o}$ is naar onze mening, dus ontstaan uit mata-n-k-ò; juist zoals limak "hand" ontstaan is uit lima-k „mijn hand”; $a m a k$,vader" uit $a m a-k$,mijn vader" enz. De auslaut $-k$ is niets anders dan een verstard teken voor de eerste persoon.

Alles bijeengenomen komt het onderscheid tussen de suffixflectie van het rottinees en die van het boeli, resp. de serandialecten, dus hierop neer, dat de oorspronkelijke oeroude possessieve constructie in een halfpersonale is omgezet. „Zijn daad” is, juist zoals in onze volkstaal vaak 
gebeurt, omgezet in "de-daad van-hem”; „mijn-daad” in „de-daad van-deze-hier". De nuance is waarlijk irrelevant, en de eerste rottinese conjugatievorm is dus typologisch thuis gebracht.

$2^{\circ}$. De suffixflectie hoort echter slechts in een uithoek van de rottinese grammatica thuis. Voor de huidige taalspreker valt de nadruk op twee geheel andere flectietypen, waarbij het subject in beide gevallen vóór de stam komt te staan. In het eerste geval komt daarbij echter géén nader contact tot stand; het werkwoord is dan dus van het „vormeloze” of ongeflecteerde type. Prof. Jonker spreekt van „onveranderlijke" werkwoorden. Maar in het tweede geval versmelten prefix en stam wèl, al dan niet met tussenschakeling van een bepaald modaal element als $f a-, k a-, l a-$ enz. Men heeft dus nu een vorm van flectie. Prof. Jonker spreekt van „veranderlijke” werkwoorden. Van lao „gaan” luidt het b.v. in het dialect van Dengka en Oènale: au lao; hò lao; eni lao; hita lao; hai lao enz. „ik ga; gij gaat; hij gaat; wij gaan” enz. Maar van een veranderlijke stam als fade "spreken”: (au) u-fade; (ho) mufade; (eni) na-fade; (hita) ta-fade enz. ,ik spreek; jij spreekt; hij spreekt; wij spreken" enz. De zelfstandige personalia zijn in het laatste geval tussen haakjes geplaatst, om aan te duiden dat de toevoeging ervan niet verplicht is.

Wat is nu het karakter van de groep der ,veranderlijke”, resp. „onveranderlijke" werkwoorden? Waarop berust het onderscheid tussen deze twee gewichtige kategorieën? Prof. Jonker heeft in zijn Spraakkunst voortdurend met dit probleem geworsteld, maar hij is er niet in geslaagd het op te lossen.

De moeilijkheid was, dat het ene deel van het materiaal steeds van het andere scheen af te wijken. Onder de ,veranderlijke" vormen b.v. leek hem de ene helft ,transitief" maar de andere even regelmatig , intransitief”. En ook bij de „onveranderlijke” vormen kwamen voortdurend „transitiva” naast ,intransitiva” voor. Tenslotte liet de hoogleraar het vraagstuk vallen, en verklaarde hij dat de variabiliteit van het rottinese werkwoord „,geheel onafhankelijk (is) van de beteekenis, ....hetzij die transitief of intransitief is". Men kan ,alleen door het gebruik" (409) leren, of een bepaald werkwoord tot het ene proclitische type behoort of tot het andere.

Is het nu echter werkelijk onvermijdelijk het hier bij een negatieve houding te laten? Kan de gestelde distinctie waarlijk niet nader worden toegelicht? De lezer zal reeds aanvoelen, welke opmerking hier als 
vanzelf voortvloeit uit het totnutoe reeds geleverde betoog. Prof. Jonker neemt a priori aan, dat de distinctie tussen de "transitiva” en de ,intransitiva” op het rottinese werkwoord toepasselijk is. Hij houdt daarmede rekening bij zijn vertalingen, splitst voortdurend de overeenkomstige betekenissen in zijn woordenboek enz. Het genoemde onderscheid past echter alleen, naar we reeds uitvoerig hebben gezien, bij het actief-energetische werkwoordstype. Daar is de overgang van de handeling aanschouwelijk; daar heeft men werkelijk een „object” naast en tegenover het „subject”, en daar kan de verhouding tussen beide, indien daar aanleiding voor is, dus ook alleen worden beoordeeld. Wie zegt echter, dat het rottinese werkwoord inderdaad van het actief-energetische type is? Prof. Jonker doet nòch in zijn Spraakkunst nòch in zijn Woordenboek een poging om dit te bewijzen. En dergelijke begrippen zonder meer uit de indogermaanse sfeer overplanten op de indonesische, is natuurlijk methodologisch ontoelaatbaar.

Het rottinese werkwoord dient in werkelijkheid, naar onze mening, echter als "passief”, d.w.z. slechts als half-,,actief” beschouwd te worden. En de distinctie tussen "transitief" en ,intransitief” is daarop dus in het geheel niet, of althans niet in de indogermaanse zin, toepasselijk. Tengevolge van zijn onjuist uitgangspunt heeft Prof. Jonker zich hier m.a.w. een zeker probleem ,geschapen”. De taalstructuur zelf weet daar echter niets van. Zijn determineringen „transitief” en ,,intransitief" berusten enkel op logisch-objectieve, d.w.z. extra-linguïstische overwegingen. Hoe valt deze laatste stelling nu te bewijzen? Hoe kan men aantonen, dat het rottinese werkwoord inderdaad van het „passieve" type is? Er staan daarvoor, naar het ons voorkomt, verschillende wegen open.

Het meest sprekende punt is wel, dat allerlei corresponderende „transitieve”, ,intransitieve” en ,causatieve” betekenissen in deze taal regelmatig door één en dezelfde vorm worden weergegeven. Dit bewijst dus, dat het rottinees zeker wel reeds een bepaalde graad van dynamiek vermag uit te drukken, maar nog niet de richting en het verdere verloop daarvan. De ontwikkeling van het werkwoord staat m.a.w. nog pas aan haar begin. We hebben hetzelfde b.v. reeds in het ngad'a gezien (156). Zo heeft men in het rottinees lenga ,achterover op de rug liggen, gaan liggen" maar ook ,achterover doen liggen”; kabebelak "plat worden" maar ook "plat maken”; nòe „smelten, oplossen" maar ook ,iets smelten”; nduna „vuil zijn” maar ook „vuil maken”; tena „zinken” 
maar ook „doen zinken”; ma-nino „verborgen, geheim zijn” maar ook „geheim houden, verbergen”; bini „zaad hebben” maar ook ,tot zaad maken, bestemmen"; su-sungu ,de oogen sluiten" maar ook "te slapen leggen”; tetè ,zich uitstorten” maar ook ,overgieten, uitgieten”; huka „zich openen" maar ook ,iets openen”; ka-bele „zich bewegen” maar ook ,,iets bewegen"; fandè ,geen geluid vernemen, doof zijn” maar ook "geen geluid maken"; lesu ,ergens uitkomen, b.v. uit een gat" maar ook ,iets ergens uittrekken”; $s a \ddot{c}$,klimmen, stijgen (intransitivum), opgestegen zijn” maar ook "zich zetten, zitten (van vogels)"; ma-tane "scherp worden of -zijn" maar ook ,scherp maken”; tetu „rechtop (staan)" maar ook ",rechtop doen zijn, recht overeind zetten"; fali (na een ander werkwoord) ,terugkeeren” maar ook ,,doen terugkeeren”; $e i$ "een voet, voeten enz. hebben, tot voeten hebben" maar ook ,,met een voet doen zijn, van een voet voorzien"; $k a$-dèle ,sterk gespannen, stevig aangehaald (zijn) bij het binden" maar ook „strak spannen”; pa-dei „staan" maar ook „doen stilstaan, tegenhouden”; mane „vorst, koning zijn of worden" maar ook "tot vorst maken (benoemen)".

Prof. Jonker behandelt in dergelijke gevallen de beide corresponderende betekenissen, naar men ziet, steeds als geheel verschillend. Zo wordt een zinnetje als dedeäk-a na-ma-ndò sò door hem vertaald met „de-zaak wordt recht ( $=$ is in orde)", maar een geheel overeenkomstige verbinding als ana feno na-ma-ndò ai-a luidt opeens ,hij buigt het hout recht". Het is echter o.i. meer overeenkomstig de geest der taal, om in het laatste geval te schrijven ,door-hem wordt-het-recht het-hout”. De gelijkheid van de vorm in beide gevallen is daarmee genoegzaam recht gedaan. De intransitieve nuance is in dergelijke gevallen dus de oorspronkelijke, en de (schijnbaar-) causatieve is daarvan slechts afgeleid tengevolge van een niet volkomen adaequate vertaling. Zo heeft men ook van ndebak transitief ana ndebak di-a neu dae ,hij smakt de paal op de grond" (beter „,door-hem valt-de-paal-met-een-smak op de grond”), maar intransitief ana ndebak nème ai lain ,hij valt (met een smak) uit een boom”. Manamafuk-a na-kala ,de beschonkene stoot zich", maar manasaë ndala-la mai la-kala ,de ruiters zullen (u) overrijden” (beter "door-de-ruiters zult (u) omvergestoten-worden”).

Dat ook de "gewone"kenmerken van het ,passieve” werkwoord, die we hierboven hebben leren kennen, in het rottinees worden teruggevonden, zal na het bovenstaande wel niemand verwonderen. Het logische object wordt hier b.v. door juist dezelfde vormen weergegeven als 
elders in de taal als subjectsindex optreden bij de suffixflectie, dat wil dus zeggen bij een speciale groep van intransitiva. Ook de zelfstandige personale vorm, die eveneens in-actief van karakter is, kan als objectsindex voorkomen. Het object geldt dus in alle gevallen als ,inert"; de verbale dynamiek is in haar verder verloop niet meer aanschouwelijk. Men heeft b.v. tè ta mate- $\dot{n}$-ò $f a$,gij zult niet sterven", maar ook $h u$ ndia dè au a-fada-ì-ò ,daarom zeg ik u"; au a-fada ò sò ,ik heb het $\mathrm{u}$ al gezegd" (au ,ik"), maar ook manafalik-a ò makamuti au ,het vorige jaar hebt gij mij uitgescholden"; bòö lungak-a mò au ,weest niet nabij met mij" = nadert mij niet ( $a u$, ,mij"). Verder is het rottinese werkwoord ook activum tantum. De passieve verbale constructie wordt, zo vermeldt Prof. Jonker uitdrukkelijk, door een actieve tournure in de derde persoon pluralis omschreven (Spraakkunst 436 vv.).

We behoeven het hier echter niet te laten bij dit resultaat van de strikt-morphologische analyse, dat toch altijd enigszins abstract en theoretisch blijft. We kunnen het toegepaste begrip van ,intransitiva” voor het rottinees nog aanmerkelijk nader omschrijven, door eenvoudig langs de weg der volledige inductie na te gaan welke betekenis-typen nu practisch in de groep der ,veranderlijke” werkwoorden voorkomen. Om hier met genoegzame zekerheid te kunnen oordelen hebben we daarom een driehonderdtal pagina's van Jonker's Woordenboek geëxcerpeerd (d.i. ruim één derde van het totaal), en de gevonden betekeniskarakteristieken in bijeenbehorende groepen gerangschikt. De uitslag komt daarbij nauwkeurig overeen met wat hierboven reeds gevonden is. Juist die rottinese werkwoorden worden proclitisch vervoegd, (en zijn dus veranderlijk), die een zekere inalienabile-intransitieve nuance met een lichte graad van dynamiek combineren. Zo wordt dus ook langs puur empirische weg bevestigd, dat het werkwoord hier van het „,passieve" type is. De structuur van de centrifugaal-dynamische handeling is de Indonesiër vreemd gebleven. Anders waren wel geheel andere betekenisgroepen voor den dag gekomen.

1. De kern van de groep der veranderlijke rottinese verba wordt gevormd door een aantal woorden voor kwalen, woonden, zickteverschijnselen enz. Hoe begrijpelijk dat juist bij dergelijke vormen de opvatting min of meer ,passief” is geworden! Andere vormen van lichamelijke reacties hebben zich bij deze kern aangesloten. Pòlo „een zeker soort van gezwel aan het achterste hebben”; poda ,rheumatische 
steken hebben in het been"; salalako ,met horten en stooten ademhalen, hijgen”; maneta „stikken, geen adem kunnen krijgen”; saleleu „misselijk zijn"; hina ,zich wonden, zich bezeeren”; dofu; kabiti ,steken van een wond"; $d a$,bloeden, *doen bloeden" ${ }^{180}$ ); nana „etteren”; dai „besmettelijk zijn van een ziekte”; fudi *,,besmetten”; pòke „,blind zijn of worden”; mulu ,gek zijn of worden”; kapedudu ,er frisch, flink uitzien”; soda ,gezond, welvarend, in welstand zijn”;

malä̈ ,hongerig zijn, honger lijden”; lòbo „zich vermoeien”; sota „,vermoeid, moede zijn”; ale „kauwen”; saboba ,slurpen, slurpend drinken”; kamumu ,omspoelen, gorgelen”; manè „,vast slapen”; lamè „,droomen”; medak ,ontwaken uit de slaap"; makate ,dik worden”; mangö̈ „,mager zijn”; nasa „drukken, persen, bijv. bij de ontlasting”; hoa (ook onveranderlijk) ,,paren, van dieren”; labi ,lust hebben tot paren, van mannelijke dieren"; nadeak ,groote behoeften verrichten”.

2. De psychologische grondslag van de kategorie der inalienabile possessie was het gevoel van $z o z i j n$. Bij alle daartoe behorende onderdelen keert dit op de één of andere wijze terug. Welnu, deze zelfde grondgedachte vindt men ook weer bij een zeer groot aantal veranderlijke verba van het rottinees, die wijzen op een $z o$ zijn of een bepaald kenmerk vertonen. Aäpa ,kleverig zijn”; kabuik ,achteraan zijn, het laatste zijn”; tola „,doordringend, scherp zijn”; kadidia ,ergens zuinig op zijn”; sapipui ,,bedorven zijn”; dei „steil zijn”; pue „,druk, levendig zijn”; pakai „,bijna gelijk zijn aan”; tatada „met lagen zijn”; siä „gewoon zijn”; bini ,,gewoon zijn, plagen”; fandi ,strak gespannen staan”; tabà „dwars (liggen enz.) ; *dwars leggen, zetten”; hòpe „op iemand gelijken”; $n d a$,overeenstemmen, bij elkaar passen”;

$a o$,een lichaam hebben, dik zijn"; isi ,inhoud, vleesch, spieren hebben”; dale, dadale ,een hart hebben"; mata ,een oog of oogen hebben"; ndana ,voorzien zijn van takken, getakt”; $\dot{n} g i$,een bloemtros hebben, aan een tros hangen"; kapò ,een opening of openingen hebben"; susula „hoorns hebben”; li ,golven hebben”; bòlo „een hol hebben”; ndunu ,nestelen, een nest hebben (*of maken)"; ana ,een kind hebben, als kind aannemen of beschouwen"; anak ,,iemand ,kind' noemen, met ,kind' aanspreken”; pala „bijvrouwen hebben (van een man gezegd)"; bana „dieren hebben"; lamatua ,als heer erkennen, beschouwen, tot heer hebben”; kalòpo „een broek dragen";

190) Met een sterretje * geven wij die gevallen aan, waar Prof. Jonker naast de intransitieve nuance ook een aparte causatieve betekenis veronderstelt. 
3. Hoe bij de toenemende dynamiek uit de nuance $z o$ zijn gemakkelijk die van zo worden kan ontstaan, is duidelijk. De sfeer blijft daarom echter even goed intransitief.

matea ,hard worden"; madema ,hoog, diep worden of geworden zijn"; madaü „licht worden, *licht maken”; mabaï „,veel worden, vermeerderen, toenemen”; matana „knappend, croquant worden”; mahenu ,vol worden”; masuï „rijk worden, rijk zijn”; ma-ana ,klein, kleiner-worden; *kleiner maken”; madò ,,ver worden, ver zijn; lang worden, lang duren";

nala „stomp maken”; lalafu „schoonmaken”; kabebenuk ,even zwaar doen zijn, even zwaar maken”; kamamau „temmen”; pòke „blind maken”; peta „doen opzwellen”; kalalapuk ,doen ontploffen, doen ontbranden”; busu „doen wegspringen”; pila ,doen ontvlammen”; kukuak „laten draven, galoppeeren”; sü̈ „,zoogen”; mate „dooden”; kababo$n g i k$,doen (helpen bij het) baren”; $k i$,doen weenen”; lalasi ,tot oudste (lasik) aanstellen".

4. Iets meer sprekend dan bij de voorgaande groep wordt de dynamiek bij een aantal verba, waarvan men de betekenis als een $z o$ doen kan karakteriseren. Dit zijn vooral denominativa en deverbalia, en $z o$ wijst daarbij op het grondwoord.

sò „eed, vloek” maar masò „,een vloek uitspreken”; tète „dam, dijk” maar katète „afdammen”; busa „,hond” maar kabubusak ,hondsch behandelen"; ape „speeksel, spog" maar aäpe ,iets met speeksel bevochtigen”; lutu ,ijzerroest” maar lulutu ,roesten”; nupu ,wat uitgeloopen is" maar $i d$. (als verbum) ,uitloopen, ontkiemen van zaden, vruchten enz."; pedu ,spruit, jong blad" maar $i d$. (als verbum) ,uitspruiten, nieuwe bladeren krijgen”; masuk ,,rook van vuur” maar masu ,rooken, dampen”; nutu ,krop van een vogel” maar ma-munutu ,pikkend.... voedsel zoeken (kippen)"; lète „smalle brug, vonder” maar palelète „langs iets smals gaan”; singo ,een zijweg inslaan, afwijken van den weg” maar singok ,voor iemand uitwijken”; seluk (onveranderlijk) „ruilen” maar $i d$. (veranderlijk) „met iemand ruilen”.

5. Zeer fraai zijn de intransitieve en de dynamische functies verder ook verenigd in een aantal vormen met de betekenis elkaar zo doen en samen zo doen. Van indogermaans standpunt zou men ook hier spoedig een transitieve nuance aanwezig achten. Voor de indonesische mentaliteit overweegt echter, dat de handeling in een dergelijke situatie niet verder reikt dan de personen der agentes zelf. De nuance is m.a.w. 
in deze ietwat gewijzigde zin ,intransitief”. En juist de vele gevallen dat eenzelfde vorm zowel de reciproke als de combinatorische betekenis heeft, bewijst dat we ons daarin niet vergissen.

fepa ao ,elkander slaan”; dodo ao „elkander dooden”; esa ,zich vereenigen”; ä̈li $a o(k)$,elkander uitschelden”; babä̈ $a o k$,onder elkander verdeelen”; dèk „,met elkander den coitus uitoefenen”; elak „elkander verlaten, v. d. echtscheiden"; kapapak "even hoog staan (van planten)”; bali „na elkander rijp worden (maisplanten)”; hikak „met elkander lachen";

doluk „tezamen hengelen”; kado ,gezamenlijk dragen”; delek „tezamen (den roffel) slaan”; hòlo „tezamen zagen”; $e \ddot{a} k$,,een bepaalden rondedans uitvoeren”; heluk „met elkander afspreken”; dudik „tezamen kruipen":

6. Twee andere betekenisgroepen, waar duidelijk een intransitief moment met een zekere dynamische nuance is verbonden, heeft men nog in de woorden voor bewegingen en geluiden. De laatste zijn in het rottinees zeer vaak van onomatopoëtisch karakter.

salelèpo „rondloopen”; lelèo „voortdurend ronddraaien”; sadea „iemand den rug toekeeren”; kadeak „naar buiten brengen”; kadalek „naar binnen brengen"; kabebapa ,met de pooten of vlerken slaan als een stervend dier";

kamú „,brommen (oorspr. wel.... het geluid $m u$ maken)"; $l i$ „geluid geven (lik)"; kaoa „schreeuwen, het geluid oa maken"; oa "braken"; $k a$-au ,het geluid an maken, schreeuwen”; salolòto „sissen (bij het braden)"; $\dot{n}$ gingiok „een krassend geluid veroorzaken”; $\dot{n} a-a o$ „miauwen”; ngòto „kraken”.

7. Naar de subjectieve kant ontwikkeld vindt men de beschreven componenten in een antal vormen met een typisch mediale bijnuance. Een bijzondere ondergroep daarvan vormen de woorden voor iets willen doen, iets graag doen (vooral van bijzonder heftige dingen gezegd), en voor steeds zo doen. In de gewoonte spreekt zich inderdaad ook veel meer van het ik uit dan in de geïsoleerde, acute daad. sengi „overwinnen in den strijd”; sapala „toegrauwen, afsnauwen”; huta. "schuld hebben, boete moeten betalen"; kalelue „weeklagen, weenen over"; kabapak "stampvoeten"; kabubula "groote oogen opzetten”; palani „dapper zijn, durven”; kalilisu ,zorg dragen voor, verzorgen”; $d \grave{o k-a}$,zich ver houden van”; kaba-batu „eene onwillige houding aannemen"; 
tabu „willen trappen, trachten te trappen"; silo ,willen schieten"; tapa ,willen werpen”; kito „willen knijpen, gaarne knijpen”; ule ,zich op allerlei wijzen zoeken los te rukken"; nòke „willen vragen, plegen te vragen"; tunga ,willen volgen";

safala „steeds gulzig dooreten, steeds doorslokken”; saingangati „herhaaldelijk juichen, jubelen”; hahala „voortdurend geluid geven”; lolò „herhaaldelijk doen dalen”; fa loloè „,herhaaldelijk tasten, vandaar: rondtasten"; fandendèlek ,herhaaldelijk goed indachtig zijn".

Overziet men nogmaals de beschreven structuur, dan kan men het geheel a.v. in beeld brengen. De overeenkomst met de vroeger behandelde groepen der inalienabile possessie spreekt onmiddellijk.

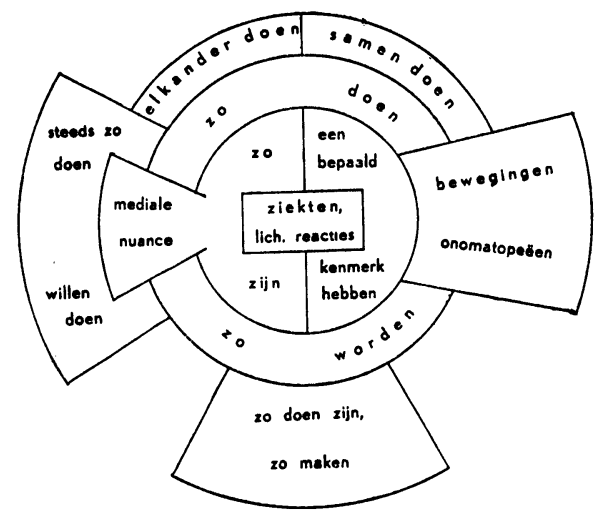

En hoe luiden nu de conclusies? Hoe is tenslotte het verbale stelsel van het rottinees gebouwd? En wat is daarvan de voorgeschiedenis?

Vooreerst is het o.i. duidelijk, dat de ,veranderlijke" proclitische flectie van het rottinees, die we hebben ontleed, niets anders is dan de typologische parallel van de hierboven reeds besproken enclitische flectie. In beide gevallen zijn het enkel de inalienabel-intransitieve verba die worden vervoegd. De methode der volledige inductie heeft ons in dit opzicht dus wel zéér vooruit gebracht. Men ziet hier de ontwikkeling zich a.h.w. voor eigen ogen voltrekken. Het is alsof de oude nominale kategorie der inalienabilia op drift is geraakt, en als zodanig in de verbale sfeer terecht gekomen is. De graad van uitgedrukte dynamiek is zéér gering. Het reeds gewonnen oordeel over het „passieve” werkwoord wordt ten volle bevestigd. 
Hiermede is tevens echter verklaard, waarom er in het rottinees naast „veranderlijke” proclitische typen ook nog „onveranderlijke” staan. De flectie drong immers in via de inalienabile begrippen, die min of meer gedynamiseerd werden. De inalienabilia vormen echter slechts een deel, en zelfs slechts het kleinste deel van de woordenschat. En zo is hier dus ook een aantal „onveranderlijke” vormen overgebleven.

Ook het verval van de enclitische flectie blijkt nu zeker op zeer goede gronden te hebben berust. Twee flectietypen van hetzelfde karakter naast elkaar in één en hetzelfde taalstelsel, is natuurlijk een onhoudbare toestand. Oorspronkelijk mogen de proclitische en de enclitische flectievormen als geheel gelijkwaardig naast elkaar hebben gestaan in de indonesische taalgeschiedenis (de eerste ontwikkelingslijn van pag. 162), later ging de voorkeur in ieder geval hoe langer hoe meer uit naar de prefixplaats (de tweede ontwikkelingslijn). Zo voegen thans nog slechts enkele tientallen van stammen in het contemporaine rottinees de persoonstekens achter de stam, terwijl de prefigering bij vele honderden van ,veranderlijke” stammen regelmatig wordt toegepast.

Alles bijeengenomen, tekent het rottinees dus op waarlijk klassieke wijze het paradigma, dat de verbale ontwikkeling van het indonesisch heeft gevolgd. Soms zijn het uiteraard slechts resten die van de ververschillende theoretisch te onderscheiden phasen zijn overgebleven, maar voorzover het geheel thans te overzien valt, is er geen enkele die ontbreekt. Slechts èèn woord van kritiek kan men hieraan nog toevoegen. Geheel stabiel is het gevormde stelsel niet. Er zijn hier krachten gewekt, die zich niet in hun loop zullen laten stuiten, al zijn ze thans tot op zekere hoogte bedwongen. En zo zullen we hierachter inderdaad Ambon-Timortalen ontmoeten, waarvan het verbale stelsel juist zo gebouwd is als dat van het rottinees, maar waarin nu alle verba worden vervoegd. En wel, zoals te verwachten viel, uitsluitend proclitisch.

\section{B) Het oirata.}

Het pronominaal systeem van het oirata, de interessante Timorese nederzetting op Kisser, die uit de eerste helft van de achttiende eeuw stamt, en die door Prof. de Josselin de Jong op voortreffelijke wijze is onderzocht ${ }^{191}$ ), ziet er enigszins vereenvoudigd a.v. uit:

191) J. P. B. de Josselin de Jong, Studies in Indonesian Culture. I Oirata, a timorese settlement on Kisar, VAWA NR 39 (1937). 


\begin{tabular}{|c|c|c|c|c|c|}
\hline & $\begin{array}{c}\text { Zelfst. } \\
\text { personale }\end{array}$ & $\begin{array}{c}\begin{array}{c}\text { Possessief } \\
\text { (gewone } \\
\text { vorm) }\end{array}\end{array}$ & $\begin{array}{l}\text { Possessief } \\
\text { (emphat. } \\
\text { vorm) }\end{array}$ & $\begin{array}{c}\text { Verbaal prefix } \\
\text { (agens bij intrans. } \\
=\text { patiens bij } \\
\text { trans.) }\end{array}$ & $\begin{array}{l}\text { Verbale agens } \\
\text { bij trans. en } \\
\text { intrans. } \\
\text { (onverbonden) }\end{array}$ \\
\hline 1 & anri & an- & an- ......-i & an- ........ (n) & ante \\
\hline 2 & èri & $\overline{\mathbf{e}}$ & $\bar{e}-\ldots \ldots . \mathrm{i}$ & $\bar{e}-\ldots \ldots \ldots$ (n) & ate \\
\hline 3 & ue & $-\mathbf{i}$ & ùe- $\ldots \ldots$. -i & ue- ........ (n) & ue \\
\hline ( incl. & apri & ap- & (ap- $\ldots \ldots$.. i & $($ ap $-\ldots \ldots \ldots$ (n) & apte \\
\hline excl. & inri & in- & in $-\ldots$ & $\sum_{\text {in }}-\ldots \ldots \ldots$ (n) & inte \\
\hline 2 & îri & i- & $\mathbf{i}-\ldots \ldots \ldots-\mathbf{i}$ & $\mathrm{i}-\ldots \ldots \ldots$ (n) & ite \\
\hline 3 & waje & waje- & waje- .... -i & waje ...... (n) & waje \\
\hline
\end{tabular}

Van de oeroude, door Jonker geconstrueerde serie $*_{k u} ; *_{m u ;}^{*} n a$ etc. is, zo blijkt uit dit overzicht, in het oirata in het geheel niets meer over. De personale stammen hebben de oorspronkelijke tekens geheel verdrongen. In dit opzicht is het oirata dus zeker opvallend ver ontwikkeld (derde ontwikkelingslijn). Ook van de distinctie tussen de alienabile en de inalienabile vormen van possessie valt hier trouwens in de huidige taalphase niets meer te bekennen, evenmin als in het rottinees. In de derde persoon singularis heeft men echter een possessief suffix $-i$. Ook de versterking bij de emphatische pronomina geschiedt regelmatig door toevoeging van hetzelfde teken. Zou men in deze plaatsing geen rest, of althans een nawerking mogen zien van de oude, zuiver enclitische inalienabile techniek? Bij de ,modern equalized form" der possessiva, waarover de Josselin de Jong spreekt, staat het $i$-teken echter weer regelmatig voorop.

Wat de verbale structuur betreft, is het voornaamste punt voor ons doel, dat de distinctie tussen de intransitieve (voorheen ,inalienabile”) en de transitieve (voorheen ,alienabile") vormen, die we in het rottinees slechts ten koste van een vrij gecompliceerd onderzoek hebben kunnen reconstrueren, in het oirata klaar en openlijk aan de dag treedt. Prof. de Josselin de Jong vond deze in zijn mythentekst onmiddellijk terug. De intransitiva worden weer vervoegd, de ontstane verbinding wordt nog zelfs speciaal door het bekende $n$-element achter de stam versterkt; maar bij de transitiva blijven subjectstekens en stam geheel los van elkander staan. Het werkwoord is nu dus nog ,vormeloos”. 
Toch zijn er aan de andere kant enkele karakteristieke punten van verschil. Vooreerst kunnen in het oirata de intransitiva ook wel geheel naar de stijl der transitiva worden behandeld. En verder treedt als subjectsindex in het laatste geval een speciale rij van tekens op die (behalve in de derde persoon) door versterking met -te uit de corresponderende intransitieve tekens is afgeleid. Op beide wijzen wordt de grens tusen de transitiva en de intransitiva, die in het rottinees nog als hermetisch gesloten was, in het oirata dus duidelijk doorbroken. Dat dit een belangrijke kans op uitbreiding voor de verbale flectie betekent, is duidelijk. De weg voor een volkomen triomf bij alle typen van verbale vormen ligt nu open, zou men geneigd zijn te zeggen. De zelfstandige personalia hebben als subjectsteken in het oirata voorgoed afgedaan. De kleine speling, die de transitiva thans nog van de flectie scheidt, is nauwelijks van belang te achten. Naast an-taja-n „I sleep” staat b.v. ante taja „,id.”; maar ante uda „I strike”, en an-uda „I am struck".

Prof. de Josselin de Jong heeft ook reeds gezien, dat het werkwoord van het oirata passief van aard is. Hoe weinig specifiek de uitdrukking van de verbale dynamiek hier is, ziet men b.v. in een geval als het reeds geciteerde an-uda. Deze vorm betekent niet alleen „I am struck” (anlijdend subject), maar ook ,somebody strikes me" (subject niet uitgedrukt; an-object); en zelfs ,who strikes for me" en ,who is struck for me" (an-datief). Men zou de gehele constructie misschien het best kunnen benaderen met „daar-bij-mij daar-slaat-het”. Naar de omstandigheden volgt dan als vanzelf de nadere determinering. Juist zo anina-n „I who am given (ina)", maar ook „who gives me" en "who is given to me".

\section{r) De Tanimbartalen.}

De conjugatie van de Tanimbartalen verschilt in zoverre van die der totnutoe behandelde talen, dat hier nu niet een vervoegde en een onvervoegde vorm tegenover elkander staan, maar enkel twee vervoegde vormen, beide van proclitische aard. De wankelheid, die het rottinees en het oirata in dit opzicht nog kenmerkte, is nu dus opgeheven. De flecterende tendenz heeft volkomen getriomfeerd, en alle verba zonder uitzondering die de taal bezit, zijn onder de ban daarvan gekomen. 
Het verschil is alleen, dat bij de eerste groep verba langere persoonstekens worden geprefigeerd, maar bij de tweede groep korte tekens. De lange tekens komen daarbij nauwkeurig overeen met de oorspronkelijke inalienabile elementen, die wij reeds kennen. Ze luiden jamdena $1 k u$ (fordata $u<k u$ ); $2 m u ; 3 n a ; 1$ ta, ma; $2 m i ; 3$ ra. De korte indices worden hieruit afgeleid door telkens de $a$-auslaut te laten vervallen. In de gevallen waarin het oorspronkelijk element op $-u$ of $-i$ uitgaat, worden deze voor consonantisch anlautende stammen in de stam zelf geïncorporeerd. De verbinding is in dit geval dus blijkbaar van bijzonder innige aard. P. Drabbe betaalt zijn tol aan de gewone opinie, en meent, juist omgekeerd als wij hebben aangenomen, dat de lange vormen uit de korte zijn afgeleid door toevoeging van een $a$-element enz. Hij spreekt steeds van „verlengde”, resp. „onverlengde” vormen $\left.{ }^{102}\right)$. Men heeft b.v. jamdena van de stam bandil „openen”, die van het korte type is: kbwandil $(<k u$-bándil); mbwandil $(<m u$ bándil); nbandil; tbandil, nbandil; mbjandil (< mi-bándil); rbandil. Maar van een lange stam als boti „zeggen”: kuboti; muboti; naboti; taboti, maboti; miboti; raboti.

De grote vraag voor ons doel is nu natuurlijk maar weer, welke structuur dit conjugatiestelsel vertoont? Dat de flectie zich tenslotte over alle verba der taal heeft uitgebreid, en dat daarvoor uitsluitend proclitische tekens zijn gekozen, vormt de moeilijkheid uiteraard niet. Het eerste punt viel te verwachten; het tweede is geheel volgens de hierboven reeds opgestelde en verklaarde ontwikkelingsregel (p. 162), waarvan we reeds verscheidene voorbeelden hebben gezien. Hoe staan hier echter de „korte” en de "lange" verbale typen zelf tegenover elkaar? Wat is de zin van deze tegenstelling, die van een type is dat we totnutoe in dit verband niet in de Ambon-Timortalen hebben ontmoet?

Zuiver typologisch gesproken, krijgt men in eerste instantie uit het voorgaande zeker reeds de indruk, dat het de verba met lange persoonstekens zijn, die in de Tanimbartalen overeenkomen met de intransitieve (,inalienabile") conjugatievorm uit de andere, reeds besproken talen. Ook hier immers is de oeroude tekenrij $*_{k u} ; *_{m u} ; *_{n a}$ practisch volkomen ongeschonden bewaard gebleven. Dergelijke ontwikkelingen in

192) P. Drabbe, Spraakkunst der Jamdeensche taal VBG 67 (1926), tweede stuk 49. 
het taalsysteem hebben zeker zin; de ,innerlijke” en de "uiterlijke” taalvorm hangen innig met elkander samen. Bij de verba met korte tekens moet het verschijnsel der conjugatie dus, relatief genomen, jonger zijn. Men zal hier voor de kategorie der transitiva (,alienabilia”) staan, die in het rottinees en het oirata nog niet werd vervoegd.

Een tweede, zeker niet minder sprekende indicatie in dezelfde richting is, dat we juist bij de lange typen ook weer het gebruik van dezelfde modale tekens aantreffen, die in het rottinees speciaal bij de intransitiva thuis horen. Naar de vorm gezien, is de overeenstemming volkomen. Maar wat de functie betreft, is er, zoals Prof. Jonker reeds heeft opgemerkt, géén overeenkomst ${ }^{193}$ ).

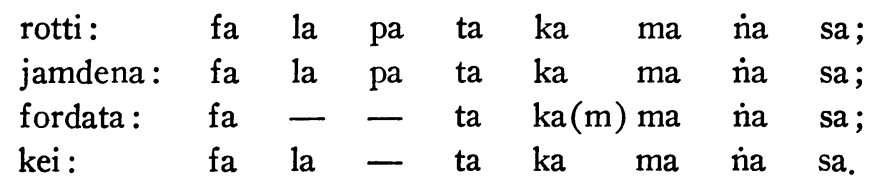

Een derde, en nu wel beslissend argument levert in dit verband echter pas weer de volledige inductie. Als men uit het woordenboek, b.v. voor het fordata, de verschillende verbale typen met lange persoonstekens excerpeert, juist zoals we dat zoëven voor het rottinees met de ,veranderlijke" vormen hebben gedaan, dan krijgt men volkomen hetzelfde stelsel. Tot in onderdelen gaat de overeenstemming door. Aan het eindoordeel valt daarom niet te twijfelen. Mèt de oeroude, inalienabile tekens hebben de verba met lange indices der Tanimbartalen ook het inalienabile structurele karakter bewaard. Ze zijn ,intransitief”. Dat deze laatste term daarbij naar de normen van het "passieve" werkwoord moet worden verstaan, en niet naar het standpunt der europese vertaling of zelfs dat der objectieve logica, spreekt na het voorgaande wel vanzelf. Ook daarover hebben we bij het rottinees reeds gesproken (167). Transitiviteit en intransitiviteit vormen nu eenmaal geen vaste „lexicologische” karakteristiek van een bepaalde stam. Ze dienen naar de aard van het betreffende taalstelsel te worden beoordeeld.

193) J. Jonker, Rottineesche Spraakkunst 142-7 (algemene aanmerking). 
Men kan in de lange vormen van het fordata de volgende ondergroepen onderscheiden ${ }^{104}$ ). 1. Daar is op de eerste plaats weer de kerngroep der namen van ziekten, ongesteldheden, wonden etc. Hoe hier juist het passief-inalienabile begrip thuis is, is zonder meer duidelijk. Een aantal woorden voor andere lichamelijke feiten heeft zich bij de kerngroep aangesloten.

$n a$ - $k$-rossi „schurft hebben”; na-f-weba (ook n-weba) „framboesiauitslag hebben, hardnekkig vuile wonden hebben"; na-f-jahavisul „,een zweertje op het ooglid hebben"; na-f-neri ,jeuk hebben”; na-babat

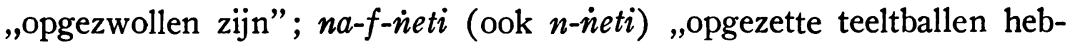
ben”; na-k-lesu ,wild vleesch aan de voeten hebben"; na-t-vidal ,openliggen van wonden"; na-b-rikit ,reeds weer bij krachten zijn (van vrouwen na het baren of van zieken)"; na-t-zeemul ,van binnen rotten (van wonden, lijken)";

na-mifi (ook n-mifi) „,droomen"; na-t-roefa , hardop droomen”; na-flidan „coïr"; na-m-kassi „,niezen”; na-f-nït „spuwen”; na-f-naän „eten”; na-s-karat „,honger hebben”; na-b-roa ,,dorst hebben”; na-f-roak ,verzorgen van.... het lichaam"; na-f-nuful ,ontdoen van kleeren of sieraden"; na-t-kosal ,te voorschijn komen, bloot liggen van de eikel (der roede)".

2. In het psychologische vertaald vindt men dezelfde inalienabiliteit ook weer terug bij een zeer grote groep van vormen die een $z o$ zijn betekenen, resp. een bepaald kenmerk vertonen. B.v. :

na-mamninak ,zoet zijn, lekker zijn”; na-s-lukut ,gebogen, gevouwen, gerimpeld zijn”; na-s-naüt „,vlug zijn”; na-m-ñä̈n „waar zijn, het meenen”; na-ñarmeran ,donker zijn”; na-k-veva ,gewonden zijn om”;

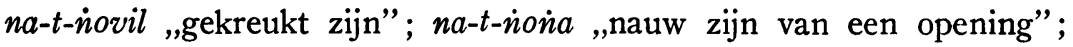
$n a-\dot{n}$-rebat ,sterk zijn, hard zijn”; na-iiar ,wit zijn, blank zijn”;

$n a-m-k u s a$,een afgebroken punt hebben”; na-t-busa ,een kleine verhevenheid hebben"; na-m-arut „,kleine scheurtjes hebben"; na-t-ruñun „een omgevouwen hoek hebben”; na-mneran „scherpe punt hebben, scherp zijn".

3. Vervolgens is er ook weer de groep woorden voor zo worden.

194) P. Drabbe, Woordenboek der Fordaatsche taal VBG 71 (1932), tweede stuk. We hebben het volledige fordata-materiaal geëxcerpeerd, maar geven om begrijpelijke redenen slechts een deel daarvan in de volgende lijsten. Een infinitief in onze zin bestaat er niet in het fordata. Met P. Drabbe worden de verschillende vormen dus telkens in de derde persoon singularis geciteerd. 
Ondanks de enorme geografische afstand zijn het soms nauwkeurig dezelfde betekeniskategorieën die hier terugkeren, als we reeds in het rottinees hebben gezien.

$n a-k$-nusi ,geschramd worden of zijn van de huid"; na-k-feffar, $n a-\dot{n}$ feffar ,breken (van aardewerk en derg.)"; na-t-betur ,middendoor breken van een staanden boom"; na-t-vahuk ,doorbreken”; na-k-bari „verzuren van etenswaren”; na-f-jahavutur ,verschimmelen, verschimmeld zijn”; na-k-bia ,verzuren”; na-k-duvul ,vollopen van prauwen, onder water gaan"; $n a-m$-ivar , in gruizelementen kapot vallen"; $n a-m$ nunur „slinken, verdwijnen van heuvels”; na-m-abat „wegslinken, wegspoelen van verhevenheden"; na-n-navi ,afbrokkelen (aardvruchten)"; na-rawan ,roesten”.

Merkwaardig is aan de andere kant dat de groep van (door iemand) zo worden, in de z.g. "causatieve" nuance van zo maken in het fordata, naar verhouding véél zwakker is vertegenwoordigd dan in het rottinees. Meestal zijn deze vormen transitief. Dit is blijkbaar een teken van aanmerkelijk verdere ontwikkeling.

na-r-waun ,,doen schudden”; na-k-sakal ,iets doen haken”; na-f-lii (ook n-lii) "doen smelten, uitstorten”; na-mukur ,rond maken (van hout)"; na-vangal „een lang voorwerp (ook mensch) het onderste boven zetten of hangen".

De gewone causatieve tekens in het fordata zijn fa- en kam-. Beide worden met de korte persoonstekens geconjugeerd. Zo b.v. na-b-lafar "honger hebben" maar n-fa-lafar ,doen hongeren”; n-diri „staan" maar n-fa-diri „,doen staan”; lolin "mooi" maar n-fa-lolin „mooi maken”; $n$-ma-aär ,uiteenvallen" maar $n$-ka-m-aär „doen uiteenvallen"; na-m-saat ,scheuren” maar n-ka-m-saat ,doen scheuren”; na-midat; na-m-feffar; na-m-rovu "breken" maar n-ka-m-idat; $n$-ka-mfeffar; $n$-ka-m-rovu ,doen breken”.

4. Ook de groep van zo doen is in het fordata vrij zwak vertegenwoordigd. De transitiva hebben deze reeds ten dele over de grens meegetrokken. Daarentegen zijn de woorden voor houdingen, geluiden en bewegingen, die puur intransitief zijn, hier weer zeer sterk vertegenwoordigd.

na-t-kilu „krom slaan van een speerpunt enz.”; na-t-bongil „scheef staan of hangen"; na-t-reva, na-toru "schuin staan, achterover leunen, overhellen"; na-m-sakal, na-t-sjakal ,met het boveneinde schuin omhoog liggen"; na-t-ñofak „op den buik liggen, het onderste boven 
liggen”; na-b-lü̈̈ „naar beneden gebogen hangen”; na-s-lura „slap hangen (touw, zeil enz.)".

na-s-dai „zich bewegen”; na-s-wail ,heen en weer slingeren, doen slingeren"; na-s-moa $\dot{n}$,in draaiende beweging zijn"; na-s-modar ,in horizontaal draaiende beweging zijn, in die beweging brengen"; na-s$k u a l$,"heen en weer draaien”; na-s-kadit ,heel vlug loopen”; na-s-niir „heel hard loopen”; na-s-votum „struikelen”; na-s-nova „trappelen”; $n a$-k-tasuk, na-m-tasuk ,wapperen van vlag, zeil enz."; na-dudur (ook $n$-dudur) ,afdalen van een helling";

$n a-t$-burik ,geluid maken met opeengeperste lippen"; $n a-k$-mêê ,blaten van geiten”; na-k-rii ,een soort jodelen”; na-k-naï „miauwen”; na-

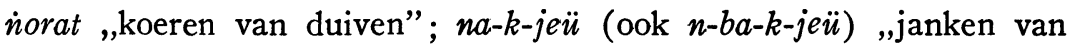
pijn of schrik (van honden)".

5. De groep mediale betekenissen is vrij krachtig in het fordata. B.v. na-b-lera ,berouw hebben”; na-rikan ,minachten, minachtend spreken over, afkeuren"; na-b-rian „,bewonderen, verwonderd zijn, schrikken”; na-f-raan „oneerbiedig bejegenen, vernederen”; na-iriki tantonan ,met wrok spreken”; na-f-reaba ,een eed doen, verwenschen”; $n a-f$-lurut ,verzoenen van de dooden door kostbaarheden te offeren"; $n a-m$-sahak „op goed geluk af iets doen of zeggen”; ra-k-lü̈r ahu ,de kampong bezweren door er eten omheen te dragen"; ra-nona ,kus-

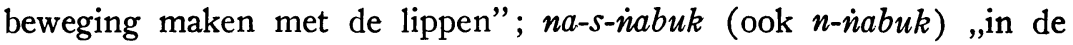
armen nemen, omhelzen";

6. Merkwaardig is, dat de mediale nuance in het fordata ook op het sociaal-ergologische is overgeslagen. Ook grote groepen woorden die betrekking hebben op de tuinbouw, vissen, handel drijven etc. vallen hier regelmatig onder de lange verbale typen. De eerste groep is daarbij aanmerkelijk groter dan de beide andere. Een typisch sociologisch trekje in de taal, dat alle aandacht verdient!

$n a-f$-taki ,verdeelen van landerijen”; na-f-n்ai (ook $n$-n்ai) ,omkappen van struikgewas bij het tuinkappen"; na-f-inoli ,kort kappen van geveld hout bij het tuinkappen"; na-f-tavat (ook n-tavat) ,met een pootstok gaten steken"; na-vaa ,poten van mais, rijst enz."; na-f-waär ,wortel schieten”; na-f-imuk ,uitschieten, uitbotten”; na-f-kuku ,vrucht zetten"; na-f-marumat ,kleine korreltjes zetten (van mais)"; na-b-ritit , in knop zijn van pisang"; na-t-botut (ook n-botut) ,uitkomen van scheuten (uit den grond)"; $n a-r u b u$,uitschieten (van planten)"; na-f-dava „oogsten of rooien van aardvruchten”; na-m-tattar (ook n-tattar) 
„opengaan van bladeren"; na-b-rofut, na-k-rofut ,afvallen van rijpe vruchten en bladeren"; na-f-rofuk ,korrels van maiskolf doen”; na-vrada „voortwoekeren van slinger- of kruipplanten”; na-f-lamin (ook $n$-lamin) „,wieden”; $n a-k$-laa ,verflensen van bloemen en bladeren”; na-m-ekit ,afbreken van boomtakken”; na-f-lawar ,,in den tuin hout bijeenslepen om het te verbranden";

$n a$-k-lita „kooken van boonen of erwten”; na-sarean „pap van aardvruchten bereiden"; ma-baa "sago bakken tusschen twee potscherven”; na-s-niera „tot koek bakken van sagomeel”; na-f-nata ,haartjes van aardvruchten doen om ze ongeschild te koken"; na-f-tomar ,uitwasemen, vochtig zijn”; na-t-umak „dampen, uitwasemen”; na-f-kokkal „opstijgen van rook"; na-jonak ,zeven, ziften”; ra-nasar (ook $r$-nasar) ,in de lengte openleggen van visch"; na-vatir ,gedeeltelijk gaar zijn”; na-f-binatan ,geheel bedorven zijn van eetwaren";

na-f-laa irit ,met de sleeplijn visschen”; na-s-velat ,werpen van het werpnet”; na-mataan „klopjacht houden op visch”; na-s-lodur (ook $n$-lodur) ,tot aan den bodem van de zee reiken (van vischlijn)"; na-kaï (ook $n$-kaï) ,haken van vischangel of anker”; na-s-lavat ,met handfuik visschen"; na-t-jaras ,wegvluchten van een school visch"; $n a$-doru ,in zee duwen van een prauw"; na-f-nera ,er staat branding”; $n a-f$-n-avoel (ook $n$-avoel) ,varen met b.v. een prauw"; na-f-nanur „zoo varen met een prauw dat de voorsteven branding maakt"; na-fnavul ,bevaren (van een boot)"; na-t-zelat „onvasten gang hebben

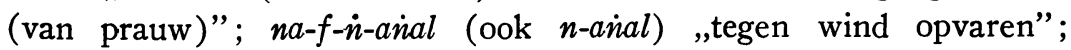
$n a-m$-evan ,stooten op (van prauwen)"; na-vaa ,stroomen van een rivier"; na-k-vuür ,onder water staan (van hooge voorwerpen)"; nadevan ,het getij neemt af"; ra-nanu (ook r-nanu) ,zwemmen”; na-veli ,handel drijven"; na-deda ,,aanbieden, rondventen”; na-f-lolwaan ,op reis zijn of gaan binnen Tanimbar".

Men ziet uit deze lijsten, dat de overeenkomsten tussen de rottinese en de fordatagroepen waarlijk treffend zijn. En er is daarom alle reden, om in de lange fordata-vormen, juist als in de vervoegde werkwoorden van het rottinees, niets anders te zien dan de verbale pendanten van de oorspronkelijke kategorie der inalienabile possessie, de ,intransitiva” dus. De korte vormen daartegenover zijn de „transitiva”. Men kan deze laatste termen rustig gebruiken, mits men ze goed verstaat.

Een laatste voordeel, wanneer men de zaken aldus beschouwt, is nog, dat daarmede ook duidelijk wordt, waarom het tekenprobleem in het 
fordata en het jamdena zo geheel anders is opgelost dan dit in de beide andere, hierboven besproken Ambon-Timortalen is geschied. Ook in het rottinees en het oirata stonden immers wel twee verbale typen tegenover elkaar. Maar het verschil daartussen werd als vanzelf reeds genoegzaam uitgedrukt, doordat het ene type geflecteerd werd en het andere niet. In de Tanimbartalen wordt echter de gehele verbale woordvoorraad vervoegd, en hier diende men dus een geheel andere weg in te slaan om de "transitiva” ook uiterlijk van de ,intransitiva” te differentiëren. De moeilijkheid was waarlijk niet gering.

Men vergete niet, dat geheel de constitutie van het verbale flectiestelsel zich hier wel onder zéér speciale condities moest voltrekken. Er was in de taal slechts één stelsel tekens beschikbaar: de vroegere nominale „possessieve” elementen. Hoe daarmede twee typen tegelijk bediend? Het rottinees en het oirata vonden een uitweg door de oude inalienabile tekens in oppositie te brengen met de zelfstandige personalia, die uitsluitend bij de ,transitieve” groep werden gebruikt. De Tanimbartalen kozen echter een oplossing, die zeker als veel origineler kan worden beschouwd. Het schijnt, dat de tegenstelling tussen de „lange" en de ,korte” tekens in deze talen enkel op een accentkwestie berust. Uit de feiten krijgt men de indruk, dat het dynamisch accent bij de lange vormen op het prefix viel; de vocalische auslaut bleef hier daardoor bewaard. Maar bij de korte vormen lag de nadruk op de eerste stamsilbe, en daarom versmolt het pronominale prefix hier zo bijzonder nauw met de stam. P. Drabbe vermeldt in zijn grammatica deze laatste punten niet met evenzoveel woorden, dit dienen we hieraan direct toe te voegen. Maar, zoals gezegd, het geschetste verloop schijnt geheel in de situatie te liggen, en daarenboven hebben de Tanimbartalen in andere, dergelijke gevallen juist dezelfde techniek toegepast ${ }^{105}$ ).

Tussen P. Drabbe en H. Geurtjens, den auteur der bekende keiese grammatica, is een debat gevoerd over de vraag of de tanimbarese werkwoorden eerder een handeling of een toestand uitdrukken ${ }^{\mathbf{1 9 6}}$ ). P. Drabbe beantwoordde de gestelde vraag bevestigend, maar P. Geurtjens meende dat hier eerder het descriptief-statische moment overwoog. Naar onze mening hebben beide deskundigen ieder voor hun deel gelijk

195) P. Drabbe, Spraakkunst der jamdeensche taal, 10, 11, 13.

198) H. Geurtjens, Over Tanimbareesch taaleigen; Tijdschrift voor Indische taal-, land- en volkenkunde 68 (1929), 276 vv. 
gehad, zoals het zo vaak gaat in dergelijke gevallen. $Z_{\mathrm{ij}}$ hebben enkel dezelfde waarheid van verschillende zijden benaderd. Het typische van het tanimbar-werkwoord (en geheel het indonesische werkwoord) is juist, dat de dynamische en de statische nuance hier broederlijk zijn verenigd. De uitdrukking is daarom nòch zuiver dynamisch-energetisch nòch puur nominaal-statisch. $\mathrm{Zij}$ is "passief" van natuur, zoals de theoretische taalkunde het zegt.

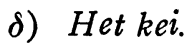

Ook in het kei heeft de flectietendenz weer volkomen getriompheerd. Alle verba die de taal kent, worden vervoegd. Het systeem kent niet minder dan vier verschillende typen. Nadere studie toont echter aan dat deze twee aan twee nauw bijeenhoren, zodat de structuur van het totaal tenslotte toch betrekkelijk eenvoudig is ${ }^{107}$ ).

1. Daar is vooreerst in het kei een tweetal possessieve flectietypen, dat opnieuw duidelijk bewijst hoe de verbale conjugatie zich in de Ambon-Timorgroep uit het nominale possessiestelsel heeft ontwikkeld. De corresponderende paradigmata staan hier nl. nog volkomen gelijk. Juist zoals men hier b.v. bij een inalienabile vorm als lima ,hand" achtereenvolgens heeft met gesuffigeerde tekens: lima-in; lima-m; lima-n ,mijn (jouw, zijn) hand” enz., zo luidt het ook bij een werkwoord als raan-en ,beminnen" enclitisch : raa-i en; raa-m en; raa-n en ,ik bemin, jij (hij) bemint" enz. Met een alienabile constructie als (yau) ni-n habo; (o) mu habo; (i) ni habo „mijn (jouw, zijn) boot” enz. komt op dezelfde wijze overeen de vervoeging van een proclitisch werkwoord als (yau) ni-ì brān; (o) mu brān; (i) ni brān; ,ik durf ; jij (hij) durft" enz. Men ziet dus a.h.w. voor zijn ogen, hoe de nominale constructietypen hier in de verbale sfeer opgenomen en gedynamiseerd worden. De gang van zaken komt volkomen overeen met wat we op ditzelfde punt in het begin van dit hoofdstuk bij het boeli en bij de serandialecten hebben gezien (163 v.).

Helaas valt de semantische verhouding van de beide verbale typen nu echter minder goed te beoordelen dan in de genoemde talen. De verba die $\mathrm{H}$. Geurtjens als enclitisch opgeeft in zijn spraakleer zijn alle, zoals te verwachten viel, van het inalienabel-intransitieve type. Men

197) H. Geurtjens, Spraakleer der keieesche taal VBG 63 (1921), tweede stuk; -, Woordenlijst der keieesche taal, ibid. derde stuk. 
vindt vormen voor gemoedsreacties, lichamelijke feiten, verschillende manieren van zo zijn enz. Het proclitisch-possessieve type telt echter in totaal slechts 18 vormen. De karakteristiek die men zich gaarne in de transitief-alienabile richting zou denken, valt daardoor niet met zekerheid vast te stellen ${ }^{198}$ ).

2. De beide beschreven possessieve flectietypen vormen blijkbaar echter slechts restverschijnselen in de kei-grammatica. Voor het huidige taalgevoel valt de nadruk practisch geheel op een tweetal proclitische typen, waarbij de oude inalienabile elementen sterk door de corresponderende personalia zijn beïnvloed. Men vindt de vormen in Haaksma's Inleiding 153 vv. Zie ook hierboven (p. 38). Het morphologisch verschil komt hierop neer, dat de persoonstekens bij het eerste type onmiddellijk aan de stam worden geprefigeerd, maar bij het tweede type wordt nog een modaal prefix tussengeschoven ${ }^{199}$.

Onze vraag van comparatief standpunt is nu natuurlijk weer, of er ook bij dit laatste deel van het kei-stelsel nog contact valt vast te stellen met het oeroude, nominale „possessieve” systeem? Blijkt ook hier met andere woorden nog iets van de groei der flectie als zodanig? Naar onze mening kan de laatste vraag veilig bevestigend beantwoord worden. Het type met tussengevoegd modaal element komt o.i. nauwkeurig overeen met de intransitief-inalienabile groepen, die we reeds in de voorgaande talen hebben gezien. De modale tekens zelf, die we al kennen, keren in het kei onmiddellijk vrijwel ongewijzigd terug. Men zie de lijst op p. 179. Het enige verschil is, dat nu de slotvocaal in de samenstelling met de verbale stam vervalt.

Het definitieve bewijs wordt ook hier echter pas weer geleverd door de volledige inductie. Als men de verba met een speciaal prefix uit

198) De volledige serie, uit Geurtjens' Woordenlijst geëxcerpeerd, volgt hieronder :

brān „moedig zijn, durven, aandurven”; $d a k$ „gierig zijn, vrekkig zijn”; en „haten, verafschuwen”; eskoet „haten, wrok toedragen, benijden”; joen „vervellen, afblotten, ontvellen"; lawan „weerstreven, tegenkanten, dwarsboomen"; madwêr (Groot Kei) „ontsnappen, vluchten, ontduiken”; madwir ,voor het eerst in een vreemd dorp komen"; majoen ,graag hebben, zich verheugen over"; malarat (G.K.) „gebrek, behoefte hebben aan iets”; maklizwoer „met iemand bevriend zijn”; miïn „wateren”; ngier „wit zijn”; ngihen „vlug zijn of doen”; rengeï „kippenvel hebben of krijgen, huiveren, walgen, misselijk zijn”; sangroean „belet, verhinderd zijn”; setan „boos zijn, kwaad zijn”; tangeen „te kort hebben, gebrek hebben aan, ontberen".

199) R. Haaksma, Inleiding 134, noot 1; verder hierboven 179. 
H. Geurtjens' Woordenlijst excerpeert en rangschikt, komen practisch dezelfde groepen voor de dag als in het rottinees en de tanimbartalen. We hebben reeds tweemaal een dergelijke lijst opgenomen; het is daarom onnodig die thans nog eens te herhalen. De hier gegeven karakteristiek komt trouwens geheel overeen met die, welke H. Geurtjens reeds van enkele der prefixgroepen afzonderlijk heeft gegeven (ba, fa, sa, ka, na; Spraakleer 29).

Men ziet dus, hoe in het kei, alles bijeengenomen, allerlei trekken uit het taalsysteem der reeds geanalyseerde meer-westelijke verwanten, tot scherper ontwikkeling zijn gekomen. Aan de andere kant wijzen echter de possessieve flectietypen, die als survivals in de structuur zijn achtergebleven, duidelijk in oostelijke en noordelijke richting. (boeli, seran). Het vermoeden is daarom niet onwaarschijnlijk, dat er in deze taal twee verschillende stromingen zijn samengekomen, die daaraan, bij alle klaarheid op andere punten, althans wat de verbale ontwikkeling aangaat, toch een zeker dubbelslachtig karakter hebben verleend ${ }^{200}$ ).

\section{b. Verbale anlautswisselingen.}

Tenslotte moeten we nog met een enkel woord spreken over de verbale anlautswisselingen, die in een aantal Ambon-Timortalen voorkomen, omdat daarin o.i. opnieuw een sterk bewijs gelegen is voor de hier gegeven voorstelling van zaken. Men benadert de verschillende flectietypen nu van een geheel andere zijde, en het oordeel valt toch gelijk uit.

De kwestie is nl. dat de verbale anlaut in sommige Ambon-Timortalen tijdens de vervoeging opeens van karakter verandert. Er komt in bepaalde personen soms een geheel andere klank voor de dag. Zo luidt het paradigma van halamai ,rufen" in het Selemandialect van Seran a.v.: 1 au-ualamai (< u-halamai); 2 au(u-) halamai; 3 ia(ni-)-halamai;

200) Eén typische merkwaardigheid van het verbale kei-stelsel verdient hier nog kort genoemd te worden. De conjugatie is hier n.l. niet bij alle modale tekens geheel volledig. Bij $d a$-, $t a-$, $m a$ - en $r a$ - bestaan alleen vormen voor de derde persoon enkel- en meervoud. De daarmee gecomponeerde verba zijn dus „unipersonaal". Alle andere typen kennen echter ook vormen voor de overige personen. In een aantal talen van Sumatra (maleis, batakdialecten) zullen we hierachter nog analoge distincties in het persoonssysteem ontmoeten (222 vv.). Van de genoemde prefixen is overigens alleen $m a$ - practisch virulent in de huidige taal. Het teken komt 70 maal voor in Geurtjens' Woordenlijst; ta-, da- en ra- echter resp. slechts 19, 2 en 4 maal. 
1 incl. ita ialamai ( $<$ i-halamai); excl. ami ialamai ( $<$ i-halamai); 2 omi ialamai (< i-halamai); 3 sio( $i$-)-lalamai (<la-halamai). Eén van de belangrijkste resultaten van Prof. Jonker's reeds meerdere malen geciteerd artikel Over de vervoegde werkwoordsvormen etc., is nu zeker geweest, dat dergelijke anlautswisselingen daarin zeer eenvoudig maar volkomen doeltreffend werden verklaard als samentrekkingen van de oorspronkelijke stamanlaut met thans buiten gebruik geraakte, geprefigeerde persoonstekens (BTLV 65 (1911), 266 vv.). We hebben deze tekens hierboven tussen haakjes reeds toegevoegd.

Eén moeilijkheid blijft op deze wijze echter over. De thans verdwenen tekens die men op de beschreven wijze gemakkelijk weer kan reconstrueren, komen niet steeds overeen met de werkelijke tekens, die op de betreffende plaatsen thuis horen. Zo is de $u$ - in $1 \mathrm{sg}$. van het paradigma hierboven zeker onmiddellijk duidelijk. Het teken is uit $k u$-, dat ieder voor deze persoon kent. Maar waar komt nu de $i$ - vandaan in 1, 2 pl.? En vanwaar la- in 3 pl.? Dergelijke vragen keren in deze gevallen steeds terug. De door Prof. Jonker gegeven verklaring lost m.a.w. slechts een deel van de moeilijkheden op. Ook Haaksma is bij nieuwe feiten van het zelfde type niet verder kunnen komen (Inleiding $164,133)$.

Welnu, naar het ons voorkomt staat men hier voor juist hetzelfde soort tekenvariaties, als we hierboven bij de inalienabile possessieve suffixen hebben gezien ( $57 \mathrm{vv}$.). In de latere periode der taalhistorie moest daar één algemene, objectieve persoonsvorm worden geconstitueerd, in plaats van de oude vormen die steeds weer een ander inalienabel teken droegen. We hebben dit proces, dat bij de nieuwe ordening der taalstructuur onvermijdelijk was, uitvoerig beschreven (52-59). We weten, dat de gewone grenzen tussen de verschillende persoonskategorieën daarbij herhaaldelijk werden doorbroken. Gewoonlijk werden de vormen van de eerste persoon enkelvoud $(k)$, van de eerste persoon meervoud inclusief $(t)$ of ook wel die van de derde persoon $(n)$ veralgemeend. Juist dezelfde grensoverschrijdingen doen zich nu echter ook bij de zojuist beschreven verbale anlautswisselingen voor. Het zijn precies dezelfde z.g. „,anorganische” tekens die nu worden veralgemeend. $Z$ o is b.v. $i$ - in 1, 2 pl. van het bovenstaande seranparadigma zeker uit de derde persoon singularis afkomstig (cfr. ninir- $i$,sein Rand"; fue-i ,sein Ursprung”); $l a$ ( $r a$ ) zal uit de derde persoon meervoud zijn, waar deze vorm in de verwante dialecten nog 
als possessief element voorkomt (Liambata, Uhei-Kachlakim (si)-ra-, naast $s i$-). Een volkomen analoge verschuiving van de derde persoonstekens hebben we hierboven reeds gezien bij de inalienabile suffixen van het galohi, en ten dele ook in het lettinees (58).

Zo vindt men in het dialect van Uhei-Kachlakim van een stam als ou ,gehen" ook regelmatig: 1 ia ou; 2 ou nou $\left(<^{*} m-o u\right) ; 3$ ir nou $(<* n-o u)$; pl. am (it, om, si) ou. Maar bij umak ,anblasen" is de $k$ van de eerste persoonsvorm secundair in het gehele singulare veralgemeend. Bij de nomina kennen we iets dergelijks al b.v. van de verwantschapsnamen, de namen van lichaamsdelen etc. in het rottinees (56). Het paradigma luidt 1 ia umak; 2 ou k-umak; 3 ir $k$-umak; it (am, om, si) umak. Men lette er nog op, hoe het $k$-element hier weggevallen is in de eerste persoon, waar het juist oorspronkelijk thuis hoort. Dit is een verschijnsel dat meer voorkomt in het taalleven. Op plaatsen waar vormtekens géén zin hebben en waar hun betekenis dus niet wordt verstaan, blijven deze vaak langer bewaard dan op die punten waar dit wel het geval is. Op dezelfde wijze heeft men ook weer in het Wahinamadialect van ino ,drinken" in 2, 3 sg. resp. u-kino en ia-kino, naar valse analogie van de eerste persoon waar het $k$-prefix zelf is weggevallen $(a-i n o)$. Over analoge verschijnselen in het sikka, ambon enz. zie men het reeds geciteerde artikel van Jonker; Haaksma, Inleiding 140, 158; Stresemann, Die Lauterscheinungen in den ambonischen Sprachen 118 vv.

Bijzonder duidelijk is de verstarring van de derde persoonstekens ook nog in het kupang. In de door Jonker meegedeelde tekst uit deze taal komen herhaaldelijk derde persoonsvormen voor, waar men andere vormen zou hebben verwacht. Zo staat er b.v. n-ahtom in plaats van *k-ahtom ,ik ontmoet"; $n$-ikit in plaats van *m-ikit ,,gij tilt"; $n$-ini in plaats van * $m$-ini ,gij ligt" enz. Zelfs in de spreektaal komen dergelijke wisselingen herhaaldelijk voor. De oorzaak daarvan zal nu wel duidelijk zijn ${ }^{201}$ ).

Op zichzelf beschouwd, zijn al dergelijke anlautsvariaties van betrekkelijk geringe betekenis. Het grote theoretische belang is echter, zoals gezegd, dat men daaruit opnieuw leert, hoe men bij de geschiedenis van de verbale flectie in de indonesische talen de nominale feiten niet

201) Jonker, Bijdragen tot de taal-, land- en volkenkunde van Nedl. Indië, zevende volgreeks, 2e deel, 252-264; Haaksma, Inleiding $132 \mathrm{v}$. 
kan missen. Indien men niet aanneemt, dat de thans verdwenen persoonstekens die de verbale stamanlaut zo diepgaand beïnloed hebben, van nominale, en wel tezelfder tijd van ,inalienabile” origine zijn, dan blijft de verklaring onvolledig. Zo beschouwd sluiten de besproken feiten dus geheel aan bij die uit het rottinees, de tanimbartalen en het kei, die we hierboven behandeld hebben. $\mathrm{Zij}$ bewijzen dat ook in andere Ambon-Timortalen dan we uitvoerig hebben kunnen analyseren, ooit een ,intransitief-inalienabel” verbaal type moet hebben bestaan.

\section{c. Het nieuwe casussysteem.}

We hebben totnutoe nog slechts de strikt-verbale zijde van de in gang zijnde ontwikkeling besproken. De constitutie van een flectiesysteem, van welk type dit verder ook is, vraagt echter aanmerkelijk méér. Ook het nominale casusstelsel voelt onmiddellijk de reflex daarvan. En teneinde onze schets niet onvolledig te doen zijn, dienen we dus ook op dit terrein de reeds begonnen lijnen door te trekken; en met name natuurlijk wat de subjects- en de objectskategorieën betreft, die het nauwst met het verbale stelsel samenhangen.

Welnu, het eerste punt dat onmiddellijk opvalt bij de nadere studie van dergelijke kwesties is, dat de sporen van de subjects- en de objectskategorieën in de Ambon-Timortalen vrijwel uitsluitend tot de pronomina zijn beperkt. Bij de nomina wordt het subject gewoonlijk enkel hierdoor gekenmerkt, dat dit, geheel onveranderd, een plaats krijgt onmiddellijk vóór het werkwoord. Het object staat op dezelfde wijze daarachter. Hoe de subjectsbepaling bij de pronomina typisch instrumentaal-ergativisch georiënteerd is, is hierboven reeds gebleken (154 v.). De objectskategorie blijft bij deze vormen vrij vaag van lijn, zoals ook geheel bij de structuur van het ,passieve” werkwoord past. Meestal is het nu enkel het enclitische element dat als index daarvoor dienst doet (rotti, kupang, ambon, serandialecten). Dit is dus juist dezelfde methode, als Prof. C. C. Uhlenbeck in een aantal noordamerikaanse indianentalen gevonden heeft. Het object staat, althans typologisch-historisch beschouwd, in de ,genitief”. Soms is echter ook in deze functie weer het zelfstandige personale ingedrongen (derde ontwikkelingslijn van pag. 162; rotti, kei, tanimbar, boeli, nufoor). Waarschijnlijk heeft deze nieuwe aanduidingsmethode, die uit andere talen met een ,passief” werkwoord b.v. ook uit het baskisch bekend is, 
hier speciaal via de gevallen van bijzondere nadruk in het taalstelsel een plaats veroverd (cfr. hierboven 138). In het paulohidialect van Seran b.v. vindt men het zelfstandig personale althans alleen in dit laatste geval. Anders wordt enkel het gewone enclitische teken gebruikt. $U$-tiha-i ,ich steche ihn”; $u$-tiha- $u$,ich steche mich”; maar $i$-tika au „er sticht mich (das Objekt betonend)" ${ }^{202}$ ).

Hoe de gevonden beperking der verbale casuspendanten verklaard moet worden, is hierboven in onze comparatieve beschouwingen reeds gebleken. De pronomina zijn in talen als de indonesische practisch altijd persoonsaanduidingen. En zo kan men uit het beschreven pronominale systeem dus wel veilig concluderen, dat ook de verbale conjugatie, dat wil dus zeggen de voornaamste oorzaak die tot het ontstaan van de subjects- en de objectskategorieën heeft geleid, hier oorspronkelijk enkel bij de groep der persoonsnamen in gebruik moet zijn geweest. De flectie is in de Ambon-Timortalen aan de mens en aan de menselijke actie gevormd. Juist hetzelfde hebben we hierboven reeds b.v. in een aantal talen van Afrika gezien (91 vv.). De eerste ,subjecten” zowel als de eerste ,objecten” waren hier namen van personen.

\section{B. De westelijke talen.}

Het grote verschil tussen de oostelijke en de westelijke indonesische talen komt bij de nomina hierop neer, zo hebben we in hoofdstuk $\mathrm{V}$ gezien, dat in het westen de distinctie tussen de beide vormen van ,possessie" vrijwel totaal verdwenen is. Hier en daar, zoals b.v. op Celebes in het mori en het bare'e, valt de nawerking daarvan nog wel te bespeuren; overal elders vindt men echter slechts één en dezelfde possessieve uitdrukkingsvorm: een primitief soort ,genitief”, die met een klein teken achter aan het woord wordt aangegeven. Het alienabile deel van het oer-austronesische stelsel, dat vóór aan het nomen een plaats vond, en waarvan we de sporen hierboven in het oosten nog herhaaldelijk hebben ontmoet, schijnt in het westen a.h.w. ineens totaal afgesneden. $\mathrm{Nu}$ sluit de verbale ontwikkeling in de indonesische talen direct bij die der nomina aan. Hoe begrijpelijk, dat dus ook in dit opzicht belangrijke verschillen zijn ontstaan tussen Oost en West! Elk van de drie ontwikkelingslijnen, die we daarvoor hierboven hebben opgesteld

202) E. Stresemann, Die Paulohisprache op. cit. 14. 
(162), heeft de weerslag daarvan ondervonden. We zullen, als inleiding op de volgende meer gedetailleerde behandeling, de voornaamste punten kort nagaan.

De eerste ontwikkelingslijn van pag. 162 stelde, typologisch zowel als historisch, de volkomen pariteit van de suffigerende en de prefigerende flectievormen vast. In de Ambon-Timortalen hadden met name de serandialecten de oude toestand in dit opzicht opmerkelijk zuiver bewaard. In de meer westelijk gesproken talen is van zulk een gelijkwaardigheid $\mathrm{nu}$ echter geen sprake meer. Men kan zeggen, dat de suffixflectie hier als regel ouder is dan de prefixflectie. De plaats vóóraan het woord bleef hier immers oorspronkelijk onbezet. De proclitische conjugatie is slechts zeer langzaam en geleidelijk ontstaan. Alleen een aantal talen van Celebes en enkele onmiddellijk ten zuiden daarvan gelegen kleine Soenda-eilanden wijken ook op dit punt weer af (bare'e, mori, boeginees, makassaars, soemba enz.). De oude „possessieve” distinctie met haar gelijke waardering voor de woordanlaut en de woordauslaut werkt hier blijkbaar nog zo krachtig na, dat ook de daarbij aansluitende proclitische en enclitische flectietypen elk in beginsel een volkomen gelijke plaats in het taalsysteem hebben gekregen. We zullen deze zelfde talen in dit verband nog herhaaldelijk ontmoeten. Ze vormen blijkbaar een zekere ,groep”. We zullen deze daarom hieronder kortweg samen als ,centrale” talen aanduiden, zonder daarmee direct een zelfstandige genealogische onderafdeling van de indonesische talen te willen constitueren.

Een tweede gevolg van het ontbreken der oeroude possessieve distincties bestaat nog hierin, dat de geleidelijke overgang van de inalienabel-nominale kategorie in een intransitief-verbaal stelsel, die we in de oostelijke talen zo vaak stap voor stap in onze lijsten hebben kunnen volgen, er in het westen geheel anders voor staat. In de „centrale" talen wordt de distinctie ,transitief” : ,,intransitief”, die zirh onmiddellijk uit de nominaal-possessieve distinctie heeft ontwkkeld, nog wel teruggevonden. Alleen op enkele punten is hier een kleine verschuiving in dit opzicht merkbaar. In de verder westelijk gesproken talen van Sumatra enz. kan men de proclitische en de enclitische typen blijkbaar echter beter als twee correlatieve graden van dynamiek tegenover elkander stellen. De enclitische flectie is, zoals ieder reeds zal hebben verwacht, naar verhouding minder dynamisch georiënteerd dan de prefixvorm. De tegenstelling "transitief" :,intransitief” is hier 
duidelijk in deze zin gereinterpreteerd. De mutatie is volkomen begrijpelijk, en geeft geen bijzondere moeilijkheden.

De tweede ontwikkelingslijn van pag. 162 betreft de latere ontwikkelingsgeschiedenis van het dubbele indonesische flectiesysteem. Langzamerhand heeft zich dit in een enkelvoudig stelsel omgezet, doordat de prefixvorm hoe langer hoe meer het overwicht verkreeg, en de enclitische pendant tenslotte op deze wijze geheel verdween. In de westelijke talen golden zonder twijfel in dit opzicht dezelfde tendenzen, die tot ontwikkeling dreven. Maar de prefigering van de persoonstekens was nu, naar we weten, naar verhouding veel meer ,onbekend" in het taalstelsel. Alleen een zekere vage herinnering aan oude oeraustronesische gewoonten kon daarbij tot oriëntatie dienen. En zo voltrok zich de constitutie der proclitische flectie nu in het algemeen ook in een zeer langzaam tempo. Het was in zekere zin volkomen ,nieuwbouw", die hier moest worden verricht.

Het voornaamste gevolg voor ons doel is geweest, dat hier daarom tot in de contemporaine taalvorm toe allerlei overgangsverschijnselen bewaard gebleven zijn, waarvan in de oostelijke talen natuurlijk geen spoor meer te bekennen valt. Het meest opvallende feit daarbij is wel het voorkomen van bepaalde dubbele affigeringstechnieken. Het transport der persoonstekens van achter naar vóór het woord is in de westelijke talen nl. blijkbaar niet ineens gelukt. De prefigering stoorde al te zeer de oude plaatsingsgewoonten. En zo is hier met name in een aantal sumatraanse talen gedurende een zekere periode gelijktijdig zowel de prefigering als de suffigering der persoonstekens toegepast (batakdialecten, gajo, maleis enz.). En pas nadat op deze wijze de proclise een zekere bekendheid had verkregen, kon de suffigering in principe uit het taalstelsel beginnen te verdwijnen. We zullen het overgangsproces hierachter in bepaalde talen stap voor stap kunnen volgen. Men weet niet wat daarbij meer te bewonderen: òfwel de stage volharding, waarmede de nieuwe stijl zich onweerstaanbaar weet door te zetten, òfwel de subtiele aanpassing die daarbij anderzijds wordt ten toon gespreid.

Ook op dit moment der ontwikkeling vertonen de centrale talen overigens weer duidelijk hun tussenpositie juist tussen de oostelijke en de westelijke verwanten in. Vooreerst valt een dubbele affigering der persoonstekens hier nergens te bekennen. De oorzaak van dit schijnbare manco is zonder meer duidelijk. Karakteristieker in dit verband is 
echter misschien nog de z.g. „omzetting van de substantief-constructie”, die niet toevallig eveneens weer speciaal in deze overgangstalen voorkomt en die daar in het taalsysteem zeer diepe wortels heeft (mori, bare'e). We zouden in dit typisch verschijnsel nl. niets anders willen zien dan een doublure van wat in de zojuist bedoelde sumatraanse talen is geschied, nu echter niet in de vol-dynamische orde van het werkwoord maar in de half-nominale, half-verbale orde van het nomen verbale. We komen hierachter op deze kwestie nog terug.

De derde ontwikkelingslijn tenslotte stelt vast, dat de oude possessieve persoonstekens bij de flectie hoe langer hoe meer zijn verdrongen door de vormen der overeenkomstige personalia. In het oosten hebben we dit proces zich reeds zien voltrekken, in het westen waar de aanschouwelijkheid der handeling naar verhouding zoveel groter is, tekent zich dit nog veel duidelijker af. Zo kan de oude rij $*_{k u} *_{m u}^{*} *_{n a}$ in de meest westelijke talen slechts met grote moeite worden teruggevonden. We hebben daarop reeds gewezen $(9 \mathrm{v}$.).

Men ziet, hoe de verschillende gegevens zich in dit schema tot een volkomen sluitend en redelijk beeld laten verenigen. De drie algemene ontreikkelingslijnen, die we hierboven hebben kunnen opstellen, blijven ook voor het westen volkomen geldig. Alleen is het relief in de structuur nu misschien iets minder diep. De beide eerste lijnen hebben tot op zekere hoogte een andere oriëntatie verkregen, de derde daarentegen komt in het westen nog meer naar voren dan in het oosten. Dat op deze wijze in de feiten geen ,tegenspraak" geschapen wordt tussen het westen en het oosten, zoals we in onze inleiding met opzet een ogenblik hebben verondersteld, spreekt vanzelf. De kwestie is eenvoudig, dat het „passieve” werkwoord een uiterst plastisch en bewegelijk vormtype is, en de ontwikkeling heeft zich hier nu enkel naar de omstandigheden telkens enigszins anders geplooid. Het hoofdkarakter blijft over het gehele terrein gelijk.

Voor de behandeling biedt het westelijke verbale stelsel ons veel meer moeilijkheden dan dat van het oosten. Door de ingetreden retardatie zijn op allerlei punten speciale ontwikkelingen ontstaan. Het beeld is zeer gevariëerd. Op al dergelijke bijzonderheden in te gaan mag men von een comparatieve beschouwing niet vergen. We zullen hieronder dus enkel de algemene trekken bespreken, die overal weer op dezelfde wijze terugkeren. 
a. De verhouding van de enclitische en de proclitische typen.

\section{a) De centraal-indonesische talen.}

Bij de eerste kennismaking zou het flectie-stelsel der centraalindonesische talen ongeveer dezelfde archaïse indruk kunnen maken als dat van de oostelijke talen. Men vindt gewoonlijk weer de intransitiva die enclitisch worden vervoegd, en daartegenover staan dan de transitiva die het persoonsteken voorop plaatsen ${ }^{203}$ ). Nadere studie doet echter al spoedig aan de dag treden, dat zich hier in werkelijkheid over het gehele terrein naast de oude punten toch ook allerlei vervalverschijnselen voordoen, die tegelijkertijd volgens de reeds besproken ,wet tot behoud van de taalkundige energie" als de eerste sporen kunnen worden beschouwd van een nieuw systeem dat bezig is zich te ontwikkelen. Men kan bij slot van rekening niets anders zeggen, dan dat het "passieve" verbale type in de centrale talen langzaam maar zeker in de richting van het actief-energetische type begint te evolueren. De sporen zijn zowel bij de subjectskategorie als bij de objectskategorie duidelijk zichtbaar. De grens van het naburige „hogere” type wordt daarbij genaderd, maar niet overschreden.

De evolutie der subjectskategorie blijkt het duidelijkst bij de tekens die daarvoor gebruikt worden. Van de oeroude ablativisch-ergativische tekens $*_{k u}$; $*_{m u ;} *_{n a}$, die zo karakteristiek waren voor de ,passieve” werkwoordsopvatting, is in de centrale talen nl. vrijwel niets bewaard gebleven. Overal, maar vooral natuurlijk als prefixen, zijn daarvoor in de plaats de zelfstandige personalia, of althans daarvan afgeleide vormen, ingedrongen (derde ontwikkelingslijn). De personale vormen echter hebben „nominativische” waarde, en horen dus in beginsel bij het ,actieve" werkwoordstype. Het kan dus wel niet anders, of er moet hier in het taalgevoel reeds een zekere nadering tussen de oudere en de nieuwere verbale opvattingen zijn ontstaan. Anders was de weg voor het personale zeker niet zo gemakkelijk gebaand geweest.

Zo beschikt b.v. het nias nog slechts bij drie personen over speciale

203) Alleen het soemba staat hier enigszins apart, omdat er twee enclitische typen zijn die tegenover het proclitische worden gesteld. Naast de gewone enclitische vorm heeft men hier nl. ook nog de z.g. substantiefconstructie. L. Onvlee, Eenige soembasche vertellingen, Diss. Leiden 1925; XLIII vv.; LXVIII vv.; LXXVI vv. 
enclitische tekens ${ }^{204}$ ), het mori nog slechts bij twee. In het boeginees zijn zelfs alle verbale suffixen zonder onderscheid practisch niets anders dan de kernen der corresponderende personalia, die daarvan met behulp van een $i$ - prefix worden afgeleid (1 sg. $i-a$ maar $-a ; 2$ sg. $i-o, i-k o$ maar $-o,-k o$ enz.). Iets dergelijks is ook in het leboni het geval. Men zie Haaksma's Inleiding 78, 90.

Ziet men het centrale tekenstelsel aldus, d.w.z. als het eindresultaat van de strijd tussen twee contradictorische beginsels, dan kan men begrijpen, hoe een taalstelsel als dat van het nias zich op een ander punt a.h.w. weer schadeloos heeft gesteld voor wat op de beschreven wijze aan kategoriale waarden verloren ging. Ook in dit geval neemt de taal in zekere zin aan de ene zijde weer terug hetgeen ze aan de andere heeft toegegeven. Naast de gewone suffixflectie kent het nias nl. ook nog een ander type, waarbij nu de zelfstandige personalia zelf achter de verbale stam worden gevoegd, en wel in wat Sundermann de „veränderte Form” genoemd heeft, d.w.z. in de status constructus. Het oorspronkelijke vaag-dynamische karakter der constructie blijft op deze wijze dus althans ten dele en langs een omweg nog bewaard. Een analoog voorbeeld zagen we al in het rottinees (165 v.). Mafôchõ-do ,ich bin krank”; managu ndrao ( $<$ n-rao, nevenvorm van $(n)-y a o$ ), ,ich nähe ${ }^{205}$ ).

Veel karakteristieker, en theoretisch ook veel meer interessant, zijn nog de verbale ontwikkelingssymptomen, die het object vertoont bij het transitivisch-proclitische stelsel der centrale talen. We hebben het „passieve" werkwoord hierboven leren kennen als een verbaal uitdrukkingsstelsel met slechts één „Leerstelle”, met de behoefte aan slechts één connotatio (zoals de scholastiek het zeide), die van het subject. Het object telt daarnaast slechts tot op zekere hoogte mee. Welnu, geheel in tegenstelling met deze diep-gefundeerde karakteristiek ziet men vooral in een antal talen van Celebes het object hoe langer hoe

204) Het nias kan natuurlijk alleen in typologische, en niet in geographische zin, tot de centraal-indonesische talen worden gerekend. De samenhang met het boeginees, mori enz. is op dergelijke punten echter onmiskenbaar. Het nias is blijkbaar een zeer archaïsche indonesische randtaal. Allerlei trekken, die elders verloren zijn gegaan of anders alleen door reconstructie te achterhalen vallen, zijn hier nog bewaard gebleven (233). H. Sundermann, Niassische Sprachlehre; 's Hage 1913.

205) H. Sundermann, Niassische Sprachlehre, 's Hage 1913, 41 v. 
meer naar voren dringen. Het verovert zich een vaste plaats in het taalstelsel, en men kan op een gegeven moment niet anders zeggen dan dat deze theoretisch van volkomen dezelfde orde is als de plaats van het subject. Het betekenisveld van het werkwoord is hiermede in beginsel dus twee-dimensionaal geworden; d.w.z. dat de status van de actief-energetische opvatting is bereikt.

Zo is de objectskategorie in talen als het napoe, bada, besoa b.v. nog totaal onspecifiek. Men kan van niets anders dan een vage objectsbepaling spreken. De proclitische vormen worden gebruikt bij transitiva ,met bepaald en onbepaald object”, zoals de grammatica het vrij onhandig formuleert. In talen als het nias en het mori komt er echter al duidelijk verandering. In het nias „(müssen) die Formen mit Präfixen.... stets.... ein Object haben...., wenigstens in Gedanken”, zo deelt Sundermann mede (42). Zo dient ook in het mori het object in ieder geval te worden aangeduid, indien dit althans een enigszins duidelijk omschreven karakter draagt ${ }^{206}$ ). De nieuwe kategorie komt hier dus blijkbaar juist zo op, als we hierboven b.v. in de moderne turkse dialecten hebben gezien (106 v.), d.w.z. juist in de definiete gevallen. Het object is in beginsel geen bepaling meer, maar een ,accusatief”. De tekens, die voorlopig ter aanduiding worden gebruikt, zijn geen andere dan de reeds besproken enclitische vormen. Zelfs als het over een nominaal object gaat, dient in het mori ook bij het werkwoord daarnaar nog te worden verwezen. Men voegt dan een suffix - $o$ toe. Men heeft b.v. $i$-kita-o, ,hij ziet het”, maar ook gagi motae $i$ Tehoe: isoea nde toeoe ka koe-ronge-o nganga-moe ",de Muis zeide: wel, komaan, laat ik je stem eens horen!" (lett. ,dat ik haar hoore, je stem”).

Men ziet dus hoe het hierboven vermelde tweede kenmerk van het „passieve" werkwoord in talen als het mori in principe komt te vervallen. Dat de aanduiding voor de nieuwe kategorie van het object voorlopig nog enkel ,inert" is, doet daarbij aan de waarde der constatering niets af. De vormen in de taal zijn op dergelijke ontwikkelingsmomenten aanvankelijk altijd enigszins onzeker en vaag. Het ,quasipleonastische" -o (zoals Esser zegt) heeft de waarde van een inleidende globale deixis, en pas daarna volgt de meer concrete aanduiding van het „bepaalde" object door het substantief.

206) S. J. Esser, Klank- en vormleer van het morisch, VBG 67 (1927), derde stuk, 96 v.; 194 v. 
$\mathrm{Er}$ is hier echter nog aanmerkelijk meer, dat ons kan interesseren. De grote verbale ontwikkelingslijn, die de centrale talen kenmerkt is met dit enkele punt nog niet voltekend. Er zijn hier nl. zelfs ook talen, waarin eveneens het derde kenmerk dat we hierboven voor het „passieve" werkwoord gegeven hebben, komt te vervallen. Het werkwoord is $\mathrm{nl}$. in een bepaalde groep westelijke Toradjatalen niet meer activum tantum. Naast het genus activum heeft zich hier ook een zekere regelrecht passieve uitdrukkingsvorm ontwikkeld, zoals Dr. Adriani in een fraaie reeks van publicaties heeft bewezen ${ }^{207}$ ). Dat ook deze laatste ontwikkeling juist in Centraal-Celebes heeft plaats gegrepen, is natuurlijk geen toeval. Het verlies der beide ,passieve” characteristica hangt nauw samen. Welke theoretische verschillen er bestaan tussen het genus activum en het genus passivum, is in een voorgaande publicatie reeds uiteengezet ${ }^{208}$ ). We kunnen daarnaar dus verwijzen.

Het beslissende punt voor ons doel is uiteraard, dat de subjects- en de objectskategorieën in de centrale Celebestalen in beginsel blijkbaar

207) N. Adriani, De beteekenis der vervoegde vormen in het bare'e. De Indische Gids; jaargang 25, I (1903), 396; - Een en ander over de werkwoorden in de bare'e-taal. Meded. Nedl. Zendel. Genootschap, D1. 53, vierde stuk (1909). N. Adriani-J. Kruyt, De bare'e-sprekende Toradja's van Midden-Celebes III, 95; N. Adriani, Spraakkunst der bare'e-taal, Verh. Kon. Bat. Gen. dl. 70.

208) J. Wils, De oorsprong van het verbale $r$-passief in de indogermaansche talen. Med. Ned. Akad. van Wetenschappen, NR, deel 3, No. 11, (1940), 7-15. Zie ook J. Wackernagel, Vorlesungen über Syntax I, 143 vv. Aangaande de aard van het passief staan er twee opvattingen tegenover elkaar. Zo houdt Brugmann b.v. de gewone theorie die ook hierboven is gereleveerd, dat nl. de spreker de passieve tournure gebruikt, indien het object de meeste aandacht had. Vandaar dat dit dan ook als subject in de zin gaat optreden (Grundrisz 2, 32, 701). Anderen, zoals b.v. Meillet, leggen er daarentegen de nadruk op, dat de figuur van de agens bij het genus passivum zéér vaag van lijn blijft (Linguistique historique et linguistique générale 195). Naar het ons voorkomt, hebben beide opvattingen recht van bestaan. Deze spreken elkaar niet tegen, maar vullen elkander juist zeer goed aan. Ook K. Vossler en Meyer-Lübke zijn met elkander in debat getreden aangaande het wezen van het passief. K. Vossler ziet in het passief speciaal „die Leidensform der Verba" (Geist und Kultur in der Sprache, 61); Meyer-Lübke daarentegen legt vooral de nadruk op het statisch moment (Die neueren Sprachen 6, 158; zie ibidem verder ook 33, 401 vv.; 34, 161 vv.). Juist zo richt Westrand zijn aandacht vooral op de intransitieve nuance (Uber das Passivum, Göteborg Kungl. Vetenskaps- och Vitterhets-Samhälles Handlingar, Sjätte Följden A 1, 10 (1941)). Naar men ziet, bestaat er ook in dit geval tussen de verschillende opvattingen eerder een klein onderscheid in nuance, dan wel een onoplosbare tegenspraak. Zie ook $\mathrm{H}$. Vogt, Un aspect du problème actif-passif dans le verbe (Journal de psychologie normale et patholigique, 1950, 130-138). 
als volkomen gelijkwaardig mogen gelden. Het object staat hier waarlijk zover niet af van de accusatief van b.v. een taal als het latijn of het grieks, welke de verschillen daartussen op andere punten uiteraard ook mogen zijn. In minder ver ontwikkelde centraal-indonesische talen, zoals b.v. het bada, soemba enz., is natuurlijk van een genus passivum geen sprake. Het object is hier niets dan een vage, onspecifieke adverbale bepaling.

Hoe de constitutie van het genus passivum in de Toradjatalen practisch verloopt, heeft Adriani reeds op voortreffelijke wijze beschreven in de geciteerde publicaties. Een korte samenvatting daarvan, met opgave van parallellen op andere taalgebieden, vindt men MAWA NR 3, 11, $33 \mathrm{vv.} \mathrm{Als} \mathrm{basis} \mathrm{voor} \mathrm{het} \mathrm{nieuwe} \mathrm{genus} \mathrm{verbi} \mathrm{dienen} \mathrm{natuur-}$ lijk, zoals altijd in dergelijke gevallen, de vormen van het reeds bestaande genus, die daaraan het nauwst verwant zijn; dat wil hier zeggen de actieve vormen van de derde persoon meervoud. Uit een constructie als *ra-pepate; ${ }^{*}$ nda-pepate ,ze hebben hem gedood, men heeft hem gedood" ontstaat „hij is gedood, hij werd gedood”. Men ziet, hoe betrekkelijk gering de semantische overgang hier is. De aanduiding voor het passieve subject blijft voorlopig nog zeer vaag. Men zou bijna zeggen: zo vaag als het maar enigszins kan. De latere ontwikkeling zal natuurlijk pas de grotere klaarte en de diepere bezinking in de structuur moeten brengen.

Zo hangt het ,passieve" werkwoord in de verst ontwikkelde talen der centraal-indonesische ondergroep theoretisch dus nog slechts als aan één zijden draadje: het enig overblijvende kenmerk van het ergativisch-instrumentale subject. Wie zal daarenboven zeggen, hoe ver ook deze laatste grondslag reeds is aangetast? De drie besproken kenmerken houden innerlijk natuurlijk nauw verband met elkaar. En veranderingen in dit opzicht op het ene punt kunnen dus niet zonder uitwerking blijven op de beide andere. Hoe dit zij, de indruk dat het werkwoord van talen als het mori en de westelijke Toradjase bergtalen reeds ten volle en zonder enige restrictie tot het energetisch-actieve type gerekend zou moeten worden, krijgt men niet. De grens van het „hogere” type wordt zeker zeer dicht benaderd, maar niet overschreden. Met name de kenmerken van de nieuwe subjectskategorie zijn voor een verder reikende conclusie, die een volkomen parallellisme met b.v. de oudere indo-europese talen zou moeten inhouden, nog te weinig sprekend. En, wat niet vergeten mag worden, ze tellen ook alleen nog 
maar voor de personalia, dat wil practisch dus zeggen voor de groep der persoonsaanduidingen ${ }^{209}$ ). $\mathrm{Bij}$ de nominale subjecten is nog geen spoor van beweging merkbaar.

Een klein kijkje op de karakteristieke sfeer waarin zich al de beschreven veranderingen hebben voltrokken, krijgt men nog in het mori. De subjectstekens zijn in deze interessante taal $\mathrm{nl}$. niet in alle tempora van het werkwoord hetzelfde ${ }^{210}$ ). In het praesens worden als regel de gewone proclitische elementen gebruikt, maar in het futurum de enclitische vormen. $\mathrm{Nu}$ blijven de menselijke handelingen, zolang ze alleen innerlijk worden overwogen, inderdaad niets anders dan vage schema's. Men komt niet uit boven een zeker „plan”. Het eigen onmiddellijke doen zet dit „plan” echter in directe werkelijkheid om. De aanvankelijke globale structuur wordt verder ,gebroken” en geleed ${ }^{211}$ ). En er schuilt nu een rijkdom en een aanschouwelijkheid in de situatie, die in geen enkele andere omstandigheid op dezelfde wijze weerkeert. Dat de Moriër in het eerste geval in zijn taal met een vrijwel inerte enclitische vorm volstond, maar in het laatste een veel heviger dynamisch teken koos, is dus volkomen begrijpelijk.

\section{B) De talen van Sumatra en Java.}

De stijging der verbale dynamiek in de talen van Sumatra, Java en Borneo is zeker niet minder sprekend dan die in de talen der oostwestelijke overgangszône, die we zoëven hebben gezien. De moeilijkheid is alleen, dat de prefixplaats voor de persoonstekens in het uiterste westen practisch onbekend was. En zo wordt het taalkundig uitdrukkingsprobleem hier ook aanmerkelijk meer gecompliceerd. Het gold hier niet alleen twee bestaande nominaal-possessieve stelsels in verbaaldynamische zin uit te bouwen. Het systeem dat daarbij de hoogste graad moest vertegenwoordigen en waarbij de persoonstekens vóóraan de stam werden toegevoegd, diende daarbij tegelijkertijd ook van de grond

209) Over de betekenis van de persoonskategorie bij het ontstaan van het passief, zie men ook E. Schwyzer, Zum persönlichen Agens beim Passiv, besonders im Griechischen. Abh. Preusz. Akad. der Wiss. 1942, No. 10.

210) S. J.Esser, Klank- en vormleer van het morisch I, op. cit. 103.

211) E. Koschmieder, Zeitbezug und Sprache, Leipzig 1929, 5, 11 v.; G. Guillaume, Temps et verbe, Paris 1929. Vgl. ook H. Pedersen, Les formes sigmatiques $\mathrm{du}$ verbe latin et le problème du futur indoeuropéen, Kgl. Danske Vid. Selsskab Meddelser 11, 5 (1921); W. Stern, Wertphilosophie, Leipzig 1924, 292 vv. 
af aan te worden opgebouwd. Vandaar de aanmerkelijke vertraging in het gehele proces, waarover hierboven reeds gesproken is. Ook bij de analyse kunnen we niet anders dan met dergelijke complicaties rekening houden. We zullen eerst de feiten bespreken voorzover die op de constitutie van het nieuwe proclitische stelsel betrekking hebben; om pas daarna meer in bijzonderheden de verhouding van de enclitische en de proclitische vormen na te gaan, die het eigenlijke doel van ons onderzoek vormt.

aa) De constitutie van het nieuwe proclitische verbale systeem.

Hebben we in de voorgaande delen reeds genoegzaam gezien, hoe geleidelijk en voorzichtig het taalproces voortgang pleegt te hebben, wanneer het over een richtingsverandering van oude tekenstelsels gaat, nog veel scherper treedt dit aan de dag in een geval als het onderhavige, waarbij een geheel nieuw vormsysteem moet worden opgebouwd. Meer dan ooit zijn de eerste schreden dan tastend en voorlopig, en pas veel later kristalliseert het definitieve stelsel zich uit. Men kan bij de constitutie der westelijke proclise globaal drie phasen onderscheiden. In de eerste phase staat vóór de stam enkel een jener-deictisch teken $d i$, ni, $s i$, $i$, dat volkomen onpersoonlijk, men zou ook kunnen zeggen alpersoonlijk is. Achter de stam volgt dan het gewone suffix, dat als meer concrete persoonsaanwijzing dient. Het overwicht in het systeem ligt hier dus duidelijk nog achter de woordstam bij het suffix. De tzeeede phase is er echter reeds duidelijk een van dubbele affigering. Zowel vóór als achter de stam staan nu, blijkbaar als gelijkwaardige helften van een tweeledig complex systeem, persoonstekens van het oude type, terwijl daarnaast vaak ook nog de $d i$-vormen uit de eerste phase blijven gehandhaafd. De weg naar het woordbegin is in de tweede phase dus in principe duidelijk gebaand. En zo kan daarna in de derde phase de proclise betrekkelijk gemakkelijk algemeen en uitsluitend worden doorgevoerd.

Verreweg de meeste sumatraanse talen, zo kan men in het algemeen zeggen, zijn op dit punt in de tweede phase blijven steken, terwijl ook nog de eerste volstrekt niet overal definitief is gepasseerd. Hoe verder men naar het westen komt, hoe sneller en vollediger het overgangsproces zich heeft voltrokken, en hoe krachtiger blijkbaar dus ook de dynamische tendenzen werkzaam zijn geweest.

$1^{\circ}$. Voorbeelden van de eerste inleidende phase, waarbij de proclise 
voorlopig nog slechts door een zwak deictisch tekentje wordt vertegenwoordigd, vindt men b.v. in het minangkabau, de batakdialecten, en verder waarschijnlijk ook in het mentawei en het enggano.

De $d i$-vorm van het minangkabau wordt, zoals te verwachten viel, alleen gebruikt in gevallen van bijzonder weinig nadruk. „De gedachte aan.... den agens”, zo zegt van der Toorn samenvattend, ,(treedt) op de achtergrond" ${ }^{212}$ ). Is de aanduiding van de agens pronominaal, dan wordt deze in de vorm van het possessief achter de stam toegevoegd. Treedt een nomen als subject op, dan wordt dit vóór of achter het werkwoord geplaatst, ingeleid door een merkwaardig teken, dat in de indonesische grammatica als ,agensaanduider” bekend staat, en dat hier eveneens weer $d i$ luidt. De plaatsing vóór het werkwoord schijnt, zoals ook wel te verwachten was, een iets scherper uitdrukking te geven dan de praeponering. Aie di-minun ,water wordt gedronken”; pitih di-tjilo kawan-ño (maar ook di kazuan-ño), ,het geld werd door zijn kameraad gestolen”. In de batakdialecten kan het z.g. „,derde passief” als voorbeeld van onze eerste phase worden genoemd ${ }^{213}$ ). Als index vóór de stam doet nu dienst het prefix $n i$-, dat in het Tobadialect na consonantische anlaut in een infix -in- wordt omgezet. De agens wordt in de batakdialecten als regel door een possessief uitgedrukt, juist als in het minangkabau. In het karo-dialect vindt men daarvoor in de plaats echter ook al de personalia (derde ontwikkelingslijn). Het substantivische subject wordt ook hier weer door een ,agensaanduider" ingeleid, die in vorm met het prefix $n i$ samenvalt. Ni-ula-m, het door u gedane"; ni-dok-ku ,het door mij gezegde (mandok)"; arta na t-inadikkon ni ama-na $i$, de goederen die door zijn vader zijn nagelaten (manadikkon)".

Wat het mentawei betreft, de door Haaksma verzamelde voorbeelden uit de mythenteksten van Loeb schijnen te bewijzen, dat ook hier een flectievorm met dubbele affigering bestaat. Als index voor de stam fungeert si, resp. $i$; achter de stam volgen de possessiva. Ook als ,agensaanduider" bij een substantivisch subject doet si hier dienst. Adriani vermeldt een dergelijk flectietype echter niet in zijn Spraakkunstige Schets (BTLV 84 (1928), 1 vv.). Vgl. Haaksma, Inleiding $40-44$. Voor het enggano ibid. 45 vv.

212) J. L. van der Toorn, Minangkabausche Spraakkunst, 's Hage 1899; 121.

213) H. N. van der Tuuk, Tobasche Spraakkunst, A'dam 1867; 169 vv.; J. H. Meerwaldt, Handleiding tot de beoefening der bataksche taal, Leiden 1904; $44 \mathrm{vv.}$ 
$2^{\circ}$. Een bijzonder fraai voorbeeld van wat we hierboven de tweede phase van het constitutieproces hebben genoemd, vindt men in de batakdialecten bij het z.g. ,eerste passief”. Enigszins vereenvoudigd, ziet het tekensysteem er hier a.v. uit (tobadialect) : ${ }^{214}$ ).

Vervoegde vorm

1. hu

2. di....hō

3. di....ibana

excl. 1. hu.... hami

incl. 1. ta....

2. di....hamu(na)

3. di....nasida
Zelfst. personale

au

hō

ibana

$\left\{\begin{array}{l}\text { hami } \\ \text { hita }\end{array}\right.$

hamu(na)

nasida
Possessivum

-hu

$-\mathrm{mu},-\mathrm{m}$

-na

-nami

-ta

$-m u(n a))$

-nasida

Men ziet dus, hoe de tekens der vervoegde vormen hier in de tweede en de derde persoon telkens uit twee delen bestaan, een proclitisch en een enclitisch deel. De aandacht is ongeveer gelijkelijk verdeeld tussen het woordbegin en het woordeinde. $D i$ - (toba, mandailing), waarmede in de dairigroep en in het karodialect $i$ - correspondeert, is blijkbaar niets anders dan het vage, deiktische element, dat we in de eerste phase reeds hebben zien optreden. De aansluiting in dit opzicht bij de vorige phase is dus bijzonder nauw. De vernieuwing toont zich alleen hierin, dat nu achter de stam niet de possessieve tekens volgen, maar de zelfstandige personalia. Dit is dus de z.g. derde ontwikkelingslijn, die we reeds herhaaldelijk hebben gezien, en die op het stijgen der dynamiek wijst (162). In de eerste persoon enkel- en meervoud (inclusief) is de prefigerende eindphase van het gehele constitutieproces echter reeds volledig bereikt.

Typisch is alleen, dat hier nu juist wel de oeroude austronesische possessieve tekens bewaard zijn gebleven, die bij de andere personen reeds door de personalia waren vervangen; $1 \mathrm{sg}$. $h u$ - is natuurlijk uit $k u$. Maar we weten al, hoe het taalproces op dergelijke momenten soms stuwt en remt tegelijk; en deze vermenging van nieuwerwetse en archaïsche trekken verrast ons dus niet. Een vorm als $h u$-dok ,door

214) H. N. van der Tuuk, Tobasche Spraakkunst, op. cit. 157 vv.; J. H. Meerwaldt, Handleiding tot de beoefening der bataksche taal, op. cit. 40 vv.; R. Haaksma, Inleiding 5-16. 
mij wordt gezegd, ik zeg", kan men zich naar onze mening dus theoretisch-typologisch ontstaan denken uit $* d i-d o k-h u$, juist zoals men thans in de tweede persoon nog heeft $d i-d o k-h \bar{o}$,door jou wordt gezegd", in de tweede persoon meervoud di-dok-hamu (na) ,door jullie wordt gezegd" enz.

$3^{\circ}$. In een aantal talen van het uiterste noord-westen (maleis, gajo, atjehs, simaloer), waarbij zich ook het lampongs heeft aangesloten, heeft tenslotte de proclise der vervoegingstekens ten volle getriomfeerd. Als zelfstandig vormbeginsel is de enclise hier totaal verdwenen. Tezelfdertijd is hier ook vrijwel overal het oeroude paradigma ${ }^{*} k u ;{ }^{*} m u$; $*_{n a}$ enz. bij de vervoeging, en zelfs ook in het possessieve stelsel, totaal geëmendeerd. Men vindt practisch bijna uitsluitend tekens die van de zelfstandige personalia zijn afgeleid. De beide ontwikkelingstendenzen, die we hierboven herhaaldelijk reeds aan het werk hebben gezien (tweede en derde lijn), hebben elkaar in deze talen dus geheel doordrongen en in hun werking versterkt.

Het bewijs, dat de aldus ontstane, nieuwe toestand aan de andere kant echter nog nauw met de beide voorgaande phasen samenhangt, wordt geleverd door een aantal typische restverschijnselen die hier voorkomen. De oude stijl blijft op allerlei punten nog door de nieuwe heenschemeren. Zo treedt in het gajo nog $-i$ op als anaphorische index voor de stam in de tweede en derde persoon enkelvoud ${ }^{215}$ ). In het moderne maleis en in het lampongs vindt men $d i$ - in de derde persoon enkel- en meervoud (mal. ku-pukul; kau-pukul; di-pukul-ña, ,ik (jij, hij) slaat”). Ook in het oud-maleis der Çrīvijaya-inscripties kon Haaksma reeds enkele van dergelijke formaties ontdekken, waarbij $n i$ - als anaphorisch prefix voorkomt (ni-galar-ku $1 \mathrm{sg}$.; ni-minun-ña 3 pl.) ${ }^{216}$ ). Dit zijn dus telkens vormingen die volgens onze telling onder de ,eerste” phase zouden vallen. In al deze gevallen treedt achter de stam het possessieve element op (mal. anak-ña ,zijn kind”). Alleen in het gajo is dit ook hier weer reeds door het overeenkomstige personale verdrongen. Zelfs komt in het gajo in een speciaal geval ook nog een zuiver enclitisch type voor; $\mathrm{nl}$. bij de met ter-gevormde verba die wijzen op een toevallig of bij ongeluk zo (geworden) zijn, resp. (na een negatie) op een onmogelijk zo

215) G. Hazeu, Gajosch-Nederlandsch Woordenboek, Batavia 1907; XVII.

216) Haaksma, Inleiding op. cit. 26. 
kunnen worden ${ }^{217}$ ). Alleen derde-persoonsvormen van dit type komen voor. De agens wordt door een possessief uitgedrukt. Typologisch gerangschikt, zouden dergelijke constructies dus nog zelfs vóór onze „,eerste" phase thuishoren! Ze staan in die zin op één lijn met de zuiver suffigerend vervoegde typen van de meer oostelijke talen als de serandialecten, het rottinees, boeginees, makkassaars etc., waarbij eveneens de verbale dramatiek slechts zeer weinig op de voorgrond trad. Gajo görö ter-balik-ē (en niet ter-balik-zwē) serenge papan ini ,hij kan alleen deze plank niet omkeren (ze is te zwaar)" ${ }^{218}$ ).

\section{De di-vormen.}

De $d i$-vormen, die hierboven besproken zijn, hebben in het debat omtrent de aard van het indonesische werkwoord steeds bijzonder de

217) G. Hazeu, Gajosch-Nederlandsch Woordenboek XIV, 945 v. Dit is het enige geval van een suffixflectie, dat Hazeu in zijn Grammaticale Aantekeningen noemt. Er zijn hier echter blijkbaar meer van dergelijke typen. In het woordenboek vindt men b.v. ook gevallen als görö sawah djelip-koe, ,ik ben het (nog) niet met mezelf eens" (180, s.v. djelip); akoe dong (of dong koe) $i$ Peparik besilo ,ik woon thans te P." (163, s.v. dong); pendjikön-koe görilon mbeh "de padi die ik te dorschen heb, is nog niet klaar" (190, s.v. djik); dapoer penitön-koe ini, dit is de oven waarbij ik mij gewarmd heb" (301, s.v. itö); ini laboe perinoemön-koe (inoemön-koe) „dit is de waterkruik, waaruit ik pleeg te drinken" (295, s.v. inoem). De possessieve tekens komen verder ook in accusatieffunctie voor; pajoeng ken pelongohön$k o e$,een pajoeng dient mij ter beschutting” (477, s.v. longoh). De regels, die voor al dergelijke gevallen gelden, zijn echter verder niet bekend.

218) Ook in het atjehs wordt blijkbaar het verschil in duidelijkheid van betekenis tussen het possessieve achtervoegsel en het corresponderende personale nog duidelijk gevoeld. Dergelijke verschijnselen hangen hier echter niet of nauwelijks samen met de flectie, en we vermelden ze daarom enkel in een noot. Zo deelt b.v. Prof. Snouck Hurgronje mee, dat de possessieve suffixen vrijwel alleen gebruikt worden ,waar eigenlijk bezit of eene na daarbij komende betrekking bedoeld wordt". Als agensaanduiding bij een handelingsnaam vindt men eerder het personale (Atjehsche taalstudien, Verspreide Geschriften V 330). Het centrifugaal element maakt in het laatste geval blijkbaar het gebruik van het meer expliciete teken noodzakelijk. Roemohkoe "mijn huis"; pengkeu ,je geld", maar liever boeët kah dan boeëtkeu ,je werk". Ook als subjectsteken treden de possessieve elementen alleen op ,in gevallen, waarin het onderwerp bijna niet vermeld behoeft te worden, omdat het spreker en aangesprokene reeds vanzelf voor den geest staat". Zoo b.v. bij de ontvangst van bruiloftsgasten na teu keunoë? „zijt gij (herwaarts) gekomen?” Er staat niet gata (bandoem) „gij” (personale), omdat ,de nadruk zoozeer (valt) op het lang verbeide feit der aankomst, dat de personen in den zin geheel op den achtergrond treden" (325). Ook als objectsteken fungeren de oorspronkelijke inalienabile elementen alleen, „wanneer het voorwerp met zoo weinig nadruk genoemd wordt, dat zijn aanduiding bijna gemist kan worden" (324). 
aandacht getrokken. Van heel wat verklaringspogingen hebben zij het centrum gevormd. Het is daarom wellicht nuttig, ook hier daarbij enigszins langer stil te staan. Hoe dient het merkwaardige $d i$-type, dat zowel in onze eerste als in de tweede phase kan vallen, te worden opgevat?

Er zijn hier o.i. twee punten, die de weg naar een goede oplossing kunnen wijzen. Vooreerst, dat de gebruikte verbale prefixen in oorsprong duidelijk locaal-deictische tekens zijn. Maleis, minangkabau $d i$ treedt elders in de taal als praepositie op met de betekenis ,te, aan, met”; batak $n i$ kan ook ,van” zijn. Het tweede punt is, dat het vrijwel steeds juist dezelfde vormen zijn, die in de verschillende talen ook als „,agensaanduider" optreden. We hebben daarop reeds gewezen. We zouden daarom het zinstype met het tot tweemaal toe herhaalde $d i$ als een geval van grammaticale en structurele congruentie willen beschouwen. Het prefix $d i$ bij het werkwoord wijst voorlopig evenzeer op de agens, als deze enige plaatsen verder in de zin concreet en onmiddellijk wordt genoemd, nu ingeleid door de ,aanduider” di. Men vergete immers niet, dat de constitutie van het proclitische verbale type niet alleen het ontstaan van een nieuwe verbale vormkategorie betekent. Wie proclise zegt, spreekt ook van casusvorming, ja noemt de zinsbouw als geheel. Men constitueert met de nieuwe verbale vorm tevens een nieuw syntactisch schema. En hoe speciaal dergelijke betrekkelijk ,jonge” constructies in het taalproces verzorgd plegen te worden, is algemeen bekend. De pas ingeoefende syntactische betrekkingen worden telkens en telkens weer aangeduid en versterkt.

Een constructie als het zoëven geciteerde zinnetje uit het minangkabau pitih di-tjilo di kazean-ño zou b.v. ongeveer kunnen worden weergegeven met "dat-geld daar-steelt-het bij(vanwege)-zijn-kameraad (van-de-zijde-van-zijn-kameraad)". Maar pitih di-tjilo kawan-ño zou eenvoudig luiden „dat-geld daar-steelt-het bij-zijn-kameraad”. In het eerste geval heeft men dus een speciaal-ergativische of -ablativische subjectsbepaling, in het tweede een totaal ongedifferentiëerde vorm. Hoe uitermate vaag de laatste aanduidingswijze is, blijkt wel hieruit, dat hetzelfde zinnetje nu ook zou kunnen betekenen „Het geld werd bij zijn kameraad gestolen". Kawan-ño geldt dan dus enkel als gewone plaatsbepaling. Er is niets in het taalsysteem dat zich tegen deze opvatting verzet. Men ziet dus, welk een verschil de toevoeging van di maakt!

Er zijn zelfs gevallen, waarin ook de dubbele deixis hier nog niet als 
voldoende geldt om het nieuwe bouwschema volledig te baseren. Als derde aanwijzing van de agens voegt men dan b.v. in het minangkabau nog eens - ño „deze, die” achter de stam. Lah sabanta nõ mana$n g i k$, di-hampiengi-ño mandai-ño ,toen hij even schreide, naderde hem zijn moeder" (daar-naderde-die-daar-zijn-moeder) ${ }^{219}$ ).

Het feit dat het juist een locale deixis is, waarmede hier voorlopig op de agens der handeling wordt gewezen, levert overigens geen moeilijkheden op. Er bestaat in dit opzicht in de talen nl. een zekere vaste hierarchie in de mogelijkheden, en de indonesische feiten schijnen juist te passen in hetgeen daarover van elders reeds bekend is. Zo onderscheidt J. van Ginneken in een studie over de pronominale anaphora in het nederlands niet minder dan zes trappen of graden van aanschouwelijkheid. De volledigheid der aanwijzing neemt steeds toe ${ }^{220}$ ). De laagste graad van deixis, zo zegt hij, is de locale deixis. Van de figuur komt nu niet meer tot uitdrukking dan het locale element (hier, daar). Een trap hoger is reeds de modale deixis, die zeer globaal van karakter is. Alleen de algemene indruk is het, die nu spreekt $(z o, z u s, a l s, d u s)$. De vierde trap is de directe deixis naar de wijze der demonstrativa, die zeer algemeen gebruikt wordt (deze, die, gindse). De derde, tweede en eerste trap tenslotte worden gevormd door de drie grammaticale „personen”, die men gewoon is bij de personalia te onderscheiden ( $h i j$, $z i j ; j i j ; i k)$.De belevingsnabijheid wordt hier steeds groter. De kern van de eigen persoonlijkheid zelf is het, die ten laatste direct en onmiddellijk wordt geraakt en in de taal aangeduid.

Welnu, al dergelijke feiten die oorspronkelijk alleen aan onze moedertaal zijn ontleend, schijnen ook een veel algemener betekenis te hebben. De zes graden of trappen van deictische aanschouwelijkheid schijnen ook elders in de talenwereld in beginsel weer terug te keren, ook al kunnen zich daar natuurlijk gemakkelijk speciale wijzigingen voordoen. Zo wees b.v. Prof. Snouck Hurgronje er reeds op, dat het voor het atjehs onmogelijk is de locale tekens voor ,hier, daar" enz. afgescheiden te behandelen van de demonstrativa, de personalia enz. ${ }^{221}$ ). De lagere en de hogere graden van aanschouwelijkheid staan hier elkaar dus vrij

219) J. L. van der Toorn, Minangkabausche Spraakkunst 125, 126.

220) J. van Ginneken, Grondbeginselen van de schrijfwijze der Nederlandsche taal ; Hilversum 1931, 134-152.

221) C. Snouck Hurgronje, Atjèhsche Taalstudien (Verspreide Geschriften V, 292 vv.). 
na, zou men in de terminologie der beschreven zesdeling kunnen zeggen. Esser vond voor het mori ongeveer hetzelfde ${ }^{222}$ ). Hij vestigt verder nog de aandacht op de vele indonesische talen, waarin de woorden voor „welk(e) ?”, die dus van de vijfde graad zijn, tevens dienst doen als equivalent voor ,waar?” (zesde graad). En zo zijn er talrijke andere dergelijke feiten meer ${ }^{223}$ ).

Voor ons doel kan men daaruit wel concluderen, dat het nieuwe type subject dat in de westelijke indonesische talen begon op te komen, vooraan de verbale stam voorlopig enkel met een pronominaal teken van de laagste, d.i. de zesde graad, werd aangeduid. De aanschouwelijkheid en de plaats in de zinsstructuur waren dus aanvankelijk nog zeer vaag en onzeker. En pas enige plaatsen verder in de zin volgt de directe aanwijzing daarvan, die nu niet meer een pronominale deixis maar een nominaal noemen is. De gang van zaken, in zijn geheel overzien, is dus zeker redelijk te noemen. Juist zo gaat het b.v. ook in het nederlands in zinnen als de volgende, waar een bepaalde figuur voorlopig slechts aan de rand van het bewustzijn verschijnt om pas later volop in het centrum daarvan te komen staan ${ }^{224}$ ); hetzelfde doet zich ook weer voor, maar nu natuurlijk in omgekeerde volgorde, wanneer men in analoge omstandigheden naar een langzaam verdwijnende hoofdfiguur terugwijst. Ik heb daar nu genoeg van! Die Jan! om mij een uur lang voor niets te laten wachten! Ik ga nooit meer naar hem toe (boos)! Professor A.; ja, daar leer je je vak zeker goed bij.

$\mathrm{H}$. N. van der Tuuk en Ch. van Ophuysen hebben het veel-besproken teken $d i$, naar men weet, speciaal met de derde grammaticale ,persoon” in verbinding gebracht. Van der Tuuk wilde $d i$ met ,door hem" vertalen, van Ophuysen meende di uit dia ,hij, hem” te kunnen afleiden. Het latere onderzoek heeft beide theorieën van de etymologisch-morphologische kant weerlegd. Ook onze eigen opvatting wijst zeker een andere richting uit. Aan de andere kant ziet men nu echter ook, welk een juiste kern er in de geciteerde gedachtengang schuilt. Als men immers de lagere deixistrappen met het stelsel der grammaticale "personen” zou willen vergelijken, dan staan deze de ,derde persoon” zeker meer

222) S. J. Esser, Klank- en vormleer van het morisch I, op. cit. 127, 129 vv.

$\left.{ }^{223}\right) \mathrm{J}$. Wils, Die Deixis der Interrogativa, in Album Philologicum - Th. Baader, Tilburg z.j. H. Frei, Système de deictiques, Acta Linguistica 4 (1944), 111.

224) J. van Ginneken, Grondbeginselen van de schrijfwijze der Nederlandsche taal $146 \mathrm{vv}$. 
na dan de „eerste” of de „tweede”. Het is de nuance van vaagheid, van gemis aan differentiatie, die de beide betekenissen aan elkander verbindt. De volle waarheid werd hier dus tenslotte slechts half gemist.

Wat speciaal de tweede phase aangaat, die we hierboven hebben onderscheiden, kan men nog vragen, waarom het hier juist de derde persoon is die steeds retardeert? Waarom zijn hier tekens als $d i, n i, i$ het langst bewaard gebleven? In de eerste persoon is de zuivere proclise het eerst ingedrongen. Slechts in een enkel geval is het enclitisch teken hier nog in functie. En de tweede persoon staat in snelheid van ontwikkeling tussen de beide andere in ${ }^{225}$ ). In de batakdialecten en in het gajo gaat deze met de derde persoon mede, maar in het maleis en het lampongs met de eerste. Wat mag de oorzaak zijn van deze typische gradatie? Men kan er in dit verband allereerst op wijzen, dat de derde persoon van nature de minst omschrevene van het drietal is. Een vaag teken als $d i, n i, i$ is daar dus ook zeker eerder op zijn plaats dan in de beide andere personen. Niemand zal daaraan twijfelen. Een veel diepere reden voor de geconstateerde verdeling is echter, dat de derde persoon in talen als de indonesische gewoonlijk op zaken wijst, maar de eerste en de tweede persoon op de spreker en zijn gesprekspartner, d.w.z. op menselijke figuren. De situatie is dus bij slot van rekening deze, dat ook de zich ontwikkelende proclise met haar meer geprononceerd type van subjectsbepaling in de westelijke talen het eerst bij hominiene agentes tot stand is gekomen. Bij niet-hominiene subjecten heeft de vroegere enclise veel langer kunnen nawerken. Hoezeer de constitutie

225) Th. Lipps, Das Wissen von fremden Ichen, Psych, Unters. I, 4 (Leipzig 1907); -, Zur Einfühlung, ibid. II, 2, 3 (Leipzig 1913); H. Plessner-F. Buytendijk, Die Deutung des mimischen Ausdrucks, ein Beitrag zur Lehre vom Bewusztsein des anderen Ichs; Philos. Anzeiger I, Bonn 1925, 75-126; H. Plessner, Die Stufen des Organischen und der Mensch, Berlin 1928; M. von Droste, Ich und der Andere, Darmstadt 1925; G. Roffenstein, Das Problem des psychologischen Verstehens, Stuttgartt 1926; H. Driesch, Der Mensch und seine Welt, Berlin 1928; K. Bühler, Die Krise der Psychologie², Jena 1929, 82-105; E. Cassirer, Philosophie der symbolischen Formen II, Berlin 1925, 191-269; III, Berlin 1929, 69 vv.; G. Ichheiser, Das Du-Bewusztsein und seine ethisch-ästhetische Struktur, Zeitschr. für angew. Psychologie 36 (1930), 369-93; J. van Ginneken, De ziel van Augustinus en haar God, Mechelen-A'dam 1930, 46-60; A. Grünbaum, Het ik-bewustzijn en de psychische ontwikkeling, Utrecht 1928, 14 v.v.; O. Janssen, Das erlebende Ich und sein Dasein, Berlin 1932, 93-99; K. Löwith, Das Individuum in der Rolle des Mitmenschen, München 1928; M. Scheler, Wesen und Formen der Sympathie ${ }^{3}$, Bonn 1931, 244-307; A. Schutz, Der sinnhafte Aufbau der sozialen Welt, Wien 1932, 106 vv., 202 vv.; L. von Wiese, Allgemeine Soziologie I, Berlin 1924, 102 vv.; II; ibid. 1929, 64 vv. 
der indonesische flectie in het teken staat van de menselijke persoon, hebben we reeds bij herhaling en uitvoerig gezien. Op dit moment der ontwikkeling, dat toch een min of meer principiële wijziging van de gehele stijl betekent, komt dezelfde karakteristiek dus eveneens weer duidelijk uit.

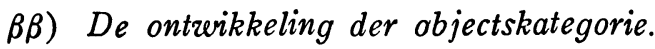

Tot zover over de geschiedenis der tekens. Wat valt er in het uiterste Westen nu echter te zeggen van de daardoor aangeduide kategorieën? Hoe is hier de structuur van het verbale systeem?

Er zijn zeker veel afwijkingen van wat we in centrale talen als het bare'e, boeginees etc. hebben gezien. Men zou zelfs een ogenblik kunnen menen hier voor een „principiëel” geheel nieuw stelsel te staan. Het meest opvallende punt is wel, dat het verbale stelsel in de talen van Sumatra en Java zo uiterst rijk geleed is. Zo staan b.v. in het javaans, de batakdialecten, het minangkabau niet minder dan vijf voorname verbale uitdrukkingstypen naast en tegenover elkaar; in het maleis heeft men zelfs zes verschillende grondtypen. Sommige van deze typen kunnen daarenboven nog verder in twee of drie subtypen worden verdeeld, naarmate de verhouding tot het object min of meer expliciet wordt aangeduid. Zonder overdrijving zou men het totale aantal vormgroepen daarom ook nog wel twee of drie hoger kunnen stellen. Een tweede merkwaardigheid is, dat de in het uiterste Westen gelegen talen, juist b.v. als het rottinees en andere meer oostelijke talen, naast vervoegde verbale vormen ook verscheidene onvervoegde typen tellen. Een derde opvallende trek tenslotte is, dat het flectiestelsel in de talen van Sumatra en Java veelal door de grammatici, waaronder de meest beroemde figuren der indonesische taalwetenschap voorkomen, als een tweeledig systeem wordt voorgesteld. Men spreekt van een aantal „actieve" vormen, en stelt daar tegenover dan een corresponderend stel „passieve” vormen. Als regel gelden de "passieve” typen dan als conjugabel en ,veranderlijk”, maar de ,actieve” niet.

Onze opgave dient natuurlijk weer te zijn orde te brengen in al deze zaken. Wijken de talen van Sumatra en Java werkelijk af van die van Celebes en elders? En is het flectiesysteem hier waarlijk tweeledig? De methode die ons onderzoek op dit moment te volgen heeft, volgt als vanzelf uit de huidige stand van ons onderzoek. Voor het javaans, dat 
een westers-centrale overgangstaal is, heeft Prof. Berg nl. reeds de verbale structuur onderzocht, en is daarbij tot conclusies gekomen die geheel liggen in de geest van het tot nu toe reeds geleverde betoog ${ }^{\mathbf{2 2 6}}$ ). We hebben dus slechts dezelfde grondgedachten ook bij de andere talen van dit gebied toe te passen. Juist zoals wij hierboven b.v. van de toenemende „zin voor dynamiek”, „het groter worden der aanschouwelijkheid", of ook wel van ,het ontstaan van een twee-dimensionaal uitdrukkingsstelsel" hebben gesproken, zo spreekt Prof. Berg voor het javaans van een aantal ,graden van activiteit" die steeds hoger stijgen. $\mathrm{Al}$ deze formuleringen noemen in de grond slechts een en hetzelfde feit. Prof. Berg houdt verder ook welbewust, dat het javaanse verbale stelsel tenslotte slechts eenledig is, juist zoals wij dit hierboven ook steeds voor andere indonesische talen hebben gedaan. Elk van de door hem onderscheiden ,graden" moge weer eigen, onverwisselbare morphologische kenmerken hebben, het is tenslotte slechts één wet, die de gehele verbale vormgeving in het javaans beheerst.

Slechts op twee ondergeschikte punten is het misschien mogelijk de conclusies van Prof. Berg's boek nog aan te vullen. En ook hieronder zullen we daarmede rekening moeten houden. Vooreerst verdient naar onze mening ook de z.g. substantiefconstructie een plaats in het verbale stelsel van het javaans. Men heeft hier weliswaar slechts de laagste of zwakst ontwikkelde trap daarvan voor zich, maar dan toch een, die in de opbouw van het geheel niet kan worden gemist (128 vv.). Het javaanse werkwoord kent naar onze mening daarom ook niet vier graden van ,,activiteit” of ,dramatisch-dynamische aanschouwelijkheid", zoals Berg aanneemt, maar vijf. Vervolgens zouden wij om historisch-comparatieve redenen ook de telling der onderscheiden graden juist anders om willen nemen dan de Leidse hoogleraar dit doet. De ge(pre)nasaleerde ,actieve” vormen, waarvan Prof. Berg uitgaat, stellen het hoogtepunt der ontwikkeling voor, dat in deze vorm slechts in enkele van de verst geëvolueerde westelijke talen bereikt is. Wij zouden er daarom ook de voorkeur aan geven, aan een dergelijk zeldzaam type de hoogste rangcijfers te verlenen, en van de vijfde activiteitsgraad te spreken. Zo blijven ook de lagere cijfers voor de lagere graden gereserveerd. Prof. Berg daarentegen daalt in zijn stelsel naar de minder actieve vormen af, terwijl de rangcijfers stijgen.

226) C. C. Berg, Bijdrage tot de kennis der javaansche werkwoordsvormen, BTLV 95 (1937); 101 v.v. 
De kwestie is nu natuurlijk maar, of het mogelijk is al de opgesomde speciale trekken in de geciteerde opvatting te verklaren. Wij zullen daartoe hieronder met name de verbale stelsels van het javaans, het maleis en de batakdialecten behandelen. De hoofdlijnen van de gevolgde redenering mogen daardoor duidelijk worden, zodat ieder deze desgewenst ook bij andere verwante talen (minangkabau, soendanees, madoerees, balinees) kan doortrekken. Ingaan op alle details, waartoe de stof anleiding zou kunnen geven, is ook nu uiteraard niet mogelijk.

\section{Het javaans.}

Men kan het verbale stelsel van het javaans ongeveer a.v. schematisch voorstellen :

\begin{tabular}{|c|c|c|c|}
\hline flectietype & morph. kenmerk & gewone benaming & Prof. Berg \\
\hline \multirow{2}{*}{ vervoegd } & 1 subst. constr. & & - \\
\hline & $2 d a k-; k o-;(d i-)$ & & 2e graad \\
\hline \multirow[b]{3}{*}{ niet-vervoegd } & $3 k e$ & „passief" & 4e graad \\
\hline & $4 k a$ & & 3e graad \\
\hline & $5\left\{\begin{array}{l}n \ldots \ldots \\
n \ldots \ldots \text { ake }(n) \\
n \ldots \ldots i\end{array}\right.$ & „actief" & le graad \\
\hline
\end{tabular}

Er schuilt zonder twijfel een zeker gevaar in het gebruik van een zuiver mathematisch schema als besluit en samenvatting van een bepaalde taalkundige analyse. In de figuur lijkt immers alles systeem, en het systeem lijkt alles. In werkelijkheid echter is het practisch taalleven veel meer complex. Er zijn hoofdtypen en afgeleide typen. Er zijn tegenstellingen van primair en van secundair belang. Strikt genomen 
zou men in een dergelijk geval daarom met een meer-dimensionaal stelsel dienen te werken. Zo gaat het ook nu weer hier. Het javaanse systeem is o.i. in de grond drieledig. Het eerste type, de z.g. substantiefconstructie vormt immers slechts een zekere inleidende trap. De hoofddistinctie ligt echter tussen het tweede en het vijfde type. Hier ligt de as, waarom het gehele systeem draait. De typen drie en vier zijn daar tegenover slechts tussenvormen, die men zich zonder bezwaar ook wel in juist de omgekeerde volgorde gerangschikt zou kunnen denken.

1. Over het eerste verbale type, de z.g. substantief-constructie, kunnen we kort zijn. Men heeft hier niets anders voor zich dan een voorbeeld van possessieve flectie. De subjectsbepaling staat in de genitief. We hebben dergelijke gevallen reeds meer ontmoet (128 vv.). De hulpvormen met olèh en $\dot{n} g o n$ vallen natuurlijk buiten de indeling. Men heeft hier met zuivere substantieven te doen.

2. Wat is nu echter het karakter der tweede en vijfde typen? Waarop berust hier de tegenstelling? Waarin wijkt b.v. een zin als akoe noelis lajang (vijfde vorm), ,ik schrijf een brief” af van een constructie als lajangé dak-toelis (tweede vorm), die schijnbaar juist hetzelfde betekent? En wat is precies de waarde van de drie verschillende sub-typen, waarin de vijfde vorm kan worden onderverdeeld?

Alle deskundigen zijn het over deze punten in de grond onderling eens, en we hebben dus niets anders te doen dan de reeds door hen gegeven karakteristieken met elkander in verband te brengen. Zo geeft Prof. Berg zeker een goede omschrijving wat de derde gestelde vraag

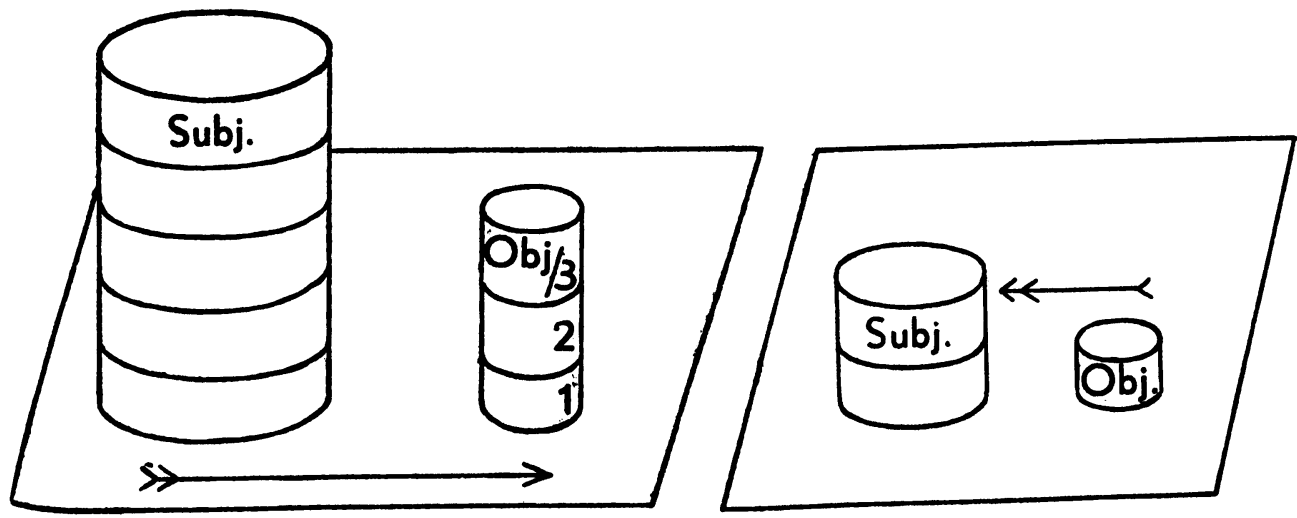

"Actief": akoe noelis lajang (5) „Passief": lajangé daktoelis $\left(^{2}\right)$ 
betreft, als hij zegt dat bij het vijfde type (,eerste graad” bij hem) „,de agens geheel op den voorgrond staat en de patiens min of meer op den achtergrond”. Bij het tweede type daarentegen (,tweede graad”) „(vragen) de agens en de patiens ongeveer in gelijke mate de aandacht, of (vraagt) misschien ook de patiens iets meer aandacht.... dan de agens" ${ }^{227}$ ). In het eerste geciteerde zinnetje wordt dus het schema, zo zou men hetzelfde wellicht van structureel standpunt kunnen formuleren, door het subject gedomineerd. Het object blijft daartegenover op het tweede plan. Er schuilt nu daarom ook een zekere dynamische trek in de betekenis. Men zou de juiste nuance ongeveer met „Ik! schrijf een brief" kunnen weergeven. In het tweede zinnetje zonder nasalering daarentegen liggen de verhoudingen juist andersom. Het is het object dat nu domineert. En het subject blijft daartegenover min of meer in het duister. Van dynamiek in enigerlei vorm is thans derhalve ook geen sprake. De plastiek in de taalaanduiding is aanmerkelijk minder sprekend dan in het voorgaande geval. „Bij-die-brief daar-schrijft-hetvanwege-mij”; ,die-brief mijn-schrijven”. Men ziet ook, hoe in beide gevallen de woordorde met opvallende nauwkeurigheid de structuurverhoudingen volgt.

Gaat men bij de ,actieve" constructie niet van een suffixloze grondvorm (eerste subtype) uit, zoals we zojuist hebben gedaan, maar van een vorm met een suffix $-a k e(n)$ (tweede subtype) of $-i$ (derde type), dan is de tegenstelling met het "passief” nog veel scherper. Bedriegen $\mathrm{nl}$. niet alle tekenen, dan stellen de drie verbindingstypen met het object, die we hierboven als drie subtypen van de éne ,actieve" grondvorm tegenover elkander hebben gesteld, in werkelijkheid niets anders voor dan drie graden van aanschouzvelijkheid bij de slotphase der verbale handeling. Juist zoals men hier bij het subject vijf graden van ,activiteit" kan onderscheiden, zo schijnt men ditzelfde ook bij het object met drie graden of vormen van ,passiviteit”, van ,getroffen worden door actie" te kunnen doen. De beide groepen van feiten hangen natuurlijk innig samen. $\mathrm{Nu}$ de subjectskategorie in de indonesische talen hoe langer hoe scherper vormen begon aan te nemen, kon ook de objectskategorie op de duur natuurlijk niet achterblijven. Ook hier moest wel verdere ontwikkeling volgen ${ }^{228}$ ).

227) C. C. Berg. Biidrage, op. cit. 101.

228) We bespreken de drie graden van het object hier speciaal bij de ,actieve" vormen, hoewel men de -ake(n)-en-i-typen soms ook in het „passief" vindt. Dit 
Welnu, de suffixloze verbinding met het object, die we hier het eerste subtype hebben genoemd, schijnt in dit verband niets anders te betekenen dan de gewone vage objectsbepaling, zoals die volkomen in de structuur van het „passieve” werkwoord past en zoals we die hierboven reeds herhaaldelijk hebben gezien.

$\mathrm{Bij}$ het derde type daarentegen wordt het object wèl rechtstreeks aangeduid, en wel door het suffix $-i$. In werkelijkheid is $-i$ een locaaldeictisch tekentje dat, versterkt met de bindklank $-n$, elders in de taal ook als voorzetsel dienst doet. Men staat hier dus voor juist dezelfde aanduidingstechniek, als we hierboven reeds bij het ontstaan van het proclitische tekenstelsel hebben leren kennen (201 vv.). Bij het werkwoord duidt $-i$ van tevoren reeds op het object, dat dan later op de gewone manier concreet en direct wordt genoemd.

Poensen verklaart, dat door de $-i$-vorm ,een betrekking (wordt) aangeduid van, een verband gelegd tussen de handeling die een gegeven subject verricht en een object; alleen nooit een object als gewrocht der handeling. Dat object is als het ware de plaats waarin, ten opzichte waarvan de handeling wordt verricht" ${ }^{229}$ ). Adja noelis-i dloewang "schrijf-niet-daar op-dat-stuk-papier" = schrijf niet op een stuk papier; mbedil-i ketju „daarginds-heen-schieten naar-een-bende-gewapenderovers" = naar een bende gewapende rovers schieten.

Het tweede verbindingstype tenslotte, de vorm met $-a k e(n)$, schijnt een zekere tussenvorm tussen het eerste en het derde type voor te stellen. Op deze manier wordt enkel uitgedrukt, dat er een bijzonder nauw verband bestaat tussen het werkwoord en het object. Van welke aard deze betrekking precies is, wordt echter geheel aan de omstandigheden en aan het spraakgebruik overgelaten. Dit is dus juist dezelfde techniek als we bij de flectietypen reeds van de z.g. possessieve flectie kennen. Poensen verklaart, dat ake, resp. aken eigenlijk ,voorzetsels (zijn), die, in het algemeen gezegd, alle betrekkingen aanduiden, welke in de arische talen door den datief en instrumentaal worden uitgedrukt: aan, naar, ten behoeve van, met....,,(De) beteekenis van zulke met het suffix -ake gevormde woorden (is) transitief, causatief of instru-

laatste gebruik schijnt echter, van comparatief standpunt beschouwd, secundair te zijn. De objectsgraden horen uiteraard allereerst bij het "transitief-actieve” type thuis. Wèl heeft men hier zonder twijfel een sterk indicium voor zich voor de nauwe verwantschap die er later tussen het "actieve" en het "passieve" systeem is gegroeid.

229) C. Poensen, Grammatica der javaansche taal, Leiden 1897, 91. 
mentatief, al naar de beteekenis die het spraakgebruik daaraan heeft toegekend" ${ }^{230}$ ). Kowe noelis-ake lajang iboe ,jij bent-aan-het-schrijvan van-een-brief voor-moeder" $=\mathrm{jij}$ schrijft een brief voor moeder; nàdeg-ake amah ,het-bouwen-ervan (eraan) een-huis” = een huis bouwen.

Tot zover de theoretische analyse. Men kan daaruit allerlei conclusies afleiden. Het voornaamste punt is wel, dat men nu ineens inziet, in hoeverre de termen ,actief" en ,passief”, die door de grammatica vrijwel algemeen voor de genasaleerde, resp. de niet-genasaleerde vormen van het javaans worden gebruikt, juist zijn. Het hoofdpunt van het indonesische spraakgebruik wordt met deze aan de westerse talen ontlede terminologie inderdaad getroffen. Dit dient men zeker toe te geven. Bij het ,actief” domineert de kategorie van het subject in de zin, zowel in het javaans als in de westerse talen, maar in het "passief” die van het daar tegenover staande object.

Gaat men nu echter verder dan dit ene punt, vat men met name de termen ,actief” en ,passief” als volkomen tegenstellingen op, zoals zij dit in de europese talen inderdaad zijn, dan ontstaat er groot gevaar voor misverstand. Dan wordt het javaanse verbale systeem geheel op de westerse leest geschoeid en als tweeledig voorgesteld. De genasaleerde vormen worden tot de niet-genasaleerde in oppositie gebracht, terwijl deze in werkelijkheid in elkanders verlengde liggen. Het javaanse stelsel is niet tweeledig, maar eenledig, zoals Prof. Berg reeds heeft gezien. Om geheel juist te zijn, dient men hier m.a.w. niet bij de structuur van het actief-energetische werkwoord te rade te gaan zoals thans veelal (onbewust) geschiedt, maar bij die van het „passieve” type. „Passief” kan, als aanduiding van de niet-genasaleerde javaanse vormen, naar onze mening daarom, zoals hierboven is uiteengezet, enkel half-actief, gematigd-actief betekenen (148). Aan ,getroffen worden door de handeling" of iets dergelijks, aan passiviteit in de zin der westerse grammatica dient men hier niet te denken.

Vandaar ook, dat wij hierboven de niet-genasaleerde vormen eerder vertaald hebben door een benaderende constructie, die aan een impersonale herinnert, dan wel door een constructie met worden, zoals gewoonlijk geschiedt. De laatste vertaling zou verkeerde bijgedachten kunnen opwekken; zij heeft dat in de loop van het debat inderdaad ook herhaaldelijk reeds gedaan. Dat op de door ons gekozen wijze geen fraaie

230) C. Poensen, Grammatica der javaansche taal, op. cit. 100, 101. 
„lopende" nederlandse constructies ontstaan, dient men zeker toe te geven. Waarom deze in een dergelijk geval onbereikbaar zijn, is zonder meer duidelijk (zie ook 148). Het gaat hier in de grond om de grammaticale constructietechniek; deze is het, die men in een comparatieve beschouwing wenst te benaderen. En deze wordt inderdaad met een impersonale tournure vrij goed bereikt. Het ,passieve” javaanse werkwoord staat veel minder ver van het flectieloze standpunt af, waarop een aantal van zijn vormen inderdaad ook nog staan, dan op het eerste gezicht misschien wel lijkt.

Hoe kan men nu echter de facto het bewijs leveren voor stellingen als deze laatste? Hoe kan men aantonen, dat het javaanse werkwoord inderdaad van het ,passieve” type is, zodat de structuur van het zoveel verder ontwikkelde actief-energetische type daarop niet toepasselijk is?

Wat de ,actieve" vormen aangaat, waarop het hier natuurlijk op de eerste plaats aankomt, kan men o.i. op twee groepen van feiten wijzen. Vooreerst is het duidelijk, dat geen enkele der transitieve constructies van het javaans, welk der drie onderscheiden subtypen men ook neemt, werkelijk overgankelijk is in de zin die deze term heeft in talen als b.v. het latijn of het sanskrit. Er blijft hier altijd, ook bij de scherpst genuanceerde vormen, nog een zekere intransitieve inslag in de betekenis. Ook op dit punt zijn de grammatici het allen met elkander eens. De kwestie is alleen, dat de intransitieve en de transitieve gebruikswijzen in de gewone handboeken meestal eenvoudig als varianten van eenzelfde grondbetekenis naast elkaar worden gesteld. Men trekt niet de volle consequenties uit het dubbele gebruik. In werkelijkheid zijn de varianten echter één. Men kan hier in de grond slechts van een gematigd-actieve betekenis spreken; en de tegenstelling tussen de transitieve en de intransitieve vormen die bij de vertaling ontstaat, dankt zijn oorsprong eerder aan het westerse taaleigen, d.w.z. aan een voor het javaans niet ter zake doende omstandigheid, dan wel aan de eigen structuur der taal zelve. Vgl. hiervoor 167.

Voor de suffixloze verbinding geeft Kiliaan reeds een aantal intransitieve gevallen op naast de gewone, z.g. transitieve nuance (Javaansche Spraakkunst 123-126). We kunnen daarnaar dus verwijzen. Men zie ook het hierboven reeds gegeven citaat van Poensen (215).

Maar ook de -i-vormen kennen hetzelfde schijnbaar tweeledige gebruik. De gewone, transitieve opvatting wordt door alle grammatici vermeld. Daarnaast komen hier echter ook gevallen voor als de vol- 
gende, die zeker niet transitief zijn in de gewone zin ( $z o$ wijst op het grondwoord).

Zich als zodanig gedragen

(voordoen)

met zovelen iets doen njenapateni ,als veldheer optreden (nl. over een leger)"; ngameli ,als stalknecht (een paard) verzorgen". nilimani ,met zijn vijven (iets doen, b.v. iemand aanvallen)";

neloni ,,de derde worden (nl. bij anderen)", d.w.z. gezamenlijk met hen iets gaan doen.

Een vorm als mateni kan ,iemand of iets doden” betekenen, maar ook in intransitief gebruik, „dodelijk, dodend” (b.v. van vergif), medeni „(iemand) vrees aanjagen" maar ook ,vreselijk”.

Wat de $a k e$-vormen aangaat, verklaart Kiliaan zeer karakteristiek, dat de betekenis hier „transitief (is), behoudens de gevallen waarin (de verbale vorm) intransitief gebezigd wordt" (135 v.). In de indogermaanse zin zijn deze termen hier dus blijkbaar niet toepasselijk.

Als zodanig beschouwen

als zodanig gebruiken

zich met iets voortbewegen mbangsatake ,(iemand) een schurk noemen";

mokolake ,(iets) onmogelijk achten";

manahake ,pijlen, een pijl afschieten";

nalunake „(iemand, iets) een halsketting omdoen";

asoe mlajokake daging ,de hond loopt weg met een stuk vleesch".

Een tweede belangrijke aanwijzing voor de slechts gematigd-dynamische opvattingen van het javaanse werkwoord heeft men verder in de woordorde, en wel speciaal in die gevallen waarin het werkwoord door twee objecten wordt vergezeld; zoals dat b.v. regelmatig bij verba van ,geven, mededelen" etc. voorkomt. Een persoonsnaam treedt nu op als ,indirect” object, maar een zaaknaam als ,direct” object. Welnu, in al dergelijke gevallen wordt het "directe" object in het javaans regelmatig tussen het werkwoord en het ,indirecte" object ingeklampt. Hoe de woordorde zich in de verschillende zinstypen ook kan wijzigen (tengevolge van een speciale nadruk b.v.), van deze regel wordt niet 
afgeweken. Het is dan ook wel op deze beide laatstgenoemde elementen, dat de zinsstructuur voornamelijk berust. Hier liggen de beide polen waartussen het zinsschema zich beweegt. Het ,indirecte” object geldt m.a.w. naar de javaanse beoordeling in werkelijkheid als de eerste verbale adstructie; het „directe” object heeft daarnaast slechts secundaire betekenis.

Dat men met deze laatste analyse niet mistast, blijkt verder nog hieruit, dat in de corresponderende passieve constructie het ,indirecte” object, d.w.z. de persoonsnaam, inderdaad als subject gaat optreden. Een volkomen consequente toepassing van het beginsel der transitiviteit in de klassieke indo-europese zin zou natuurlijk hebben geëist, dat het „directe" object, d.w.z. de zaaknaam als zodanig fungeerde. Men heeft b.v. Sang Nata maringi gandjaran sénapati ,de vorst begiftigt den veldheer met een belooning" ${ }^{231}$ ), maar in het passief sénapati diparingi gandjaran Sang Nata ,de veldheer wordt door den koning met een belooning begiftigd".

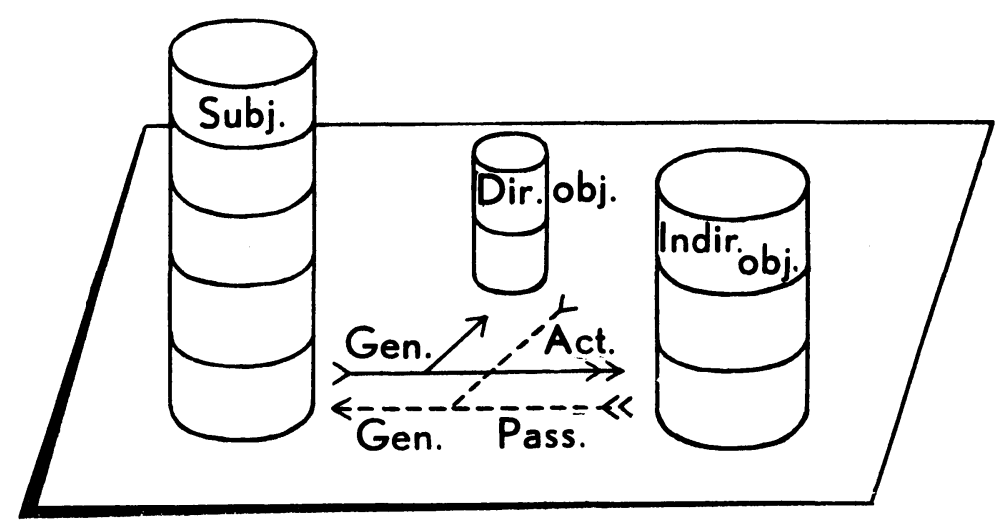

Op analoge feiten in enkele moderne europese talen, waarin het werkwoord eveneens sterk aan dynamisch-dramatische aanschouwelijkheid heeft ingeboet, hebben we hierboven reeds gewezen (146).

231) Dr. M. Prijohoetomo vertaalt deze laatste zin met „De vorst schenkt den veldheer een belooning" (Javaansche Spraakkunst 177). Het dynamisch-transitieve moment der handeling treedt bij het werkwoord "schenken” echter sterk op de voorgrond, hetgeen in het javaans juist niet het geval is. Wij hebben hier daarom liever de voorkeur gegeven aan "begiftigen”, dat een meer passieve nuance vertegenwoordigt. 
Wat het tweede type, d.w.z. de niet-genasaleerde vormen met dak-; ko- etc. betreft, uit het voorgaande volgt reeds, dat de karakteristiek „passief" hier niet in de westerse zin van een genus passivum kan gelden. Wie een zin als het hierboven geciteerde voorbeeld lajangè daktoelis met "die brief wordt door mij geschreven” of iets dergelijks vertaalt, legt meer aan grammaticale structuur in de javaanse tekst dan daar in werkelijkheid in aanwezig is, en geeft daardoor aanleiding tot verwarring. Voor de mogelijkheid van een dergelijke weergave wordt vereist, dat de subjects- en de objectskategorie in het taalsysteem een volkomen gelijkwaardige positie hebben verworven. Onze beschouwingen van zoëven hebben echter aangetoond, dat van een dergelijke ontwikkelingshoogte in het javaans nog geen sprake is. Het object moge in deze taal reeds aanmerkelijk scherpere tekening verkregen hebben dan b.v. in de oostelijke indonesische talen het geval is, de gelijke van het subject is deze kategorie daarom nog niet.

De kwestie is dat er in het javaans tussen de ,actieve” en de "passieve” vormen geen tegenstelling bestaat. De „passieve” graden vormen slechts de inleiding tot de hogere, die enkel in de zojuist besproken zin ,actief” (vollediger: ,gematigd actief”) mogen heten. Wil men de verhouding in cijfers uitdrukken, zoals we dat hierboven ook in hoofdstuk XIII hebben gedaan, dan zou men hier, de "passieve” vormen b.v. op 50 kunnen stellen, maar de ,actieve" vormen op 75 of 80 . Met de namen der westerse genera verbi hebben de gebruikte termen in dit geval dus niets te maken.

Een tweede, en nu rechtstreeks bewijs voor deze laatste stelling heeft men nog in de typische verdeling, die het verschijnsel der persoonsflectie in het javaans vertoont ${ }^{232}$ ). Waarom worden hier immers de „passieve" vormen regelmatig ,vervoegd", althans in de eerste en de tweede persoon singularis ${ }^{233}$ ), maar de "actieve" vormen niet? We weten reeds, dat de agens bij het geflecteerde werkwoord der indonesische talen enkel wordt aangeduid, in zoverre deze als organiserend en richting-gevend moment bij de handeling betrokken is. De actie zelf

232) Een andere indicatie voor de nauwe verwantschap tussen de ,actieve" en de ,passieve" stelsels van het javaans is hierboven reeds kort genoemd (214, noot 1).

233) Het teken $d i$ - van de derde persoon is geen persoonsindex in dezelfde zin als 1 dak- en 2 ko-. Het is daarom beter deze persoon hier niet toe te voegen. Vgl. hierboven 209. 
wordt als een zo worden, zich zo ontwikkelen opgevat. Welnu, met deze diep-gebaseerde trek is bij de vormen met $d a k$-, resp. ko- blijkbaar ten volle rekening gehouden. De zinsstructuur blijft nu vaag en globaal. Bij de genasaleerde vormen van het ,actief" breekt echter een zekere individualistische opvatting door. De objectivering is nu aanmerkelijk scherper. Handelen geldt nu in principe als een $z o$ doen, of beter nog misschien als een daar doen, daar maken. De betekenisstructuur is in beginsel twee-dimensionaal. En vandaar dat nu ook géén persoonsteken aan de stam wordt toegevoegd. Het werkwoord blijft „vormeloos”, zoals de oudere taalwetenschap het formuleerde. Was de structuur van het actief-energetische flectietype in het javaans reeds ten volle doorgevoerd, dan zouden omgekeerd zeker juist de "actieve” vormen zijn „,vervoegd”, maar de lagere, z.g. „passieve” graden van activiteit niet $^{234}$ ).

3. We kunnen het hierbij laten, voorzover het de tweede en vijfde typen van het javaanse werkwoord betreft. Over de derde (ke-) en vierde typen $(k a-)$, die nog niet besproken werden, kunnen we kort zijn. Deze beide laatste typen zijn onderling nauw verwant. In beide gevallen wordt hier in het geheel niet meer op de agens gelet; bij $k a-$ omdat men enkel het resultaat der voltooide handeling wil weergeven, bij $k e$ - omdat de actie volkomen onopzettelijk of onwillekeurig is geschied. In die zin valt de nadruk hier dus uitsluitend op het object. Ook hier spreken de grammatici daarom gewoonlijk van ",passieve” vormen. Sénapati ka-paringan gandjaran warna-zearna ,de aanvoerder werd begiftigd met allerlei geschenken”; ke-bandjiran „overstroomd worden, te lijden hebben van overstrooming".

4. Rest nog slechts hieraan toe te voegen, dat het gebruik der proclitisch verbogen vormen in het oud-javaans veel uitgebreider was dan thans het geval is. De aanschouwelijkheid der handeling is in de latere taalperioden dus blijkbaar sterk toegenomen, juist zoals we dat in de voorgaande hoofdstukken reeds in allerlei andere dergelijke gevallen hebben gezien. Men had in het oud-javaans b.v. vervoegingsprefixen voor alle personen, zowel in het enkel- als in het meervoud; en de vervoeging kon zowel bij „transitiva” als bij ,intransitiva” voorkomen. Dat echter ook dergelijke vormen van het ,passieve” flectietype waren, volgt wel hieruit, dat zij, op enkele uitzonderingen na,

234) Vgl. hierboven 160 v.v. 
uitsluitend in afhankelijke zinnen, of anders in verbinding met bepaalde partikels, zoals b.v. de ontkenning $t a$, konden voorkomen. De nadruk ligt hier uiteraard op de handeling van de hoofdzin; die van de bijzin blijft daardoor onvermijdelijk min of meer in het duister. Merang aku $g$-lawana $k o$, ik schaam mij om jou te bestrijden”; yak-anon ,wanneer ik zie” ${ }^{235}$ ). In ,het taaleigen van de middel-javaanse gedichten als de Kidung-Sündayana" komen de verbogen vormen, zo deelt Berg mede, echter weer "slechts zeer zelden” voor ${ }^{236}$ ).

Vergelijkt men tenslotte de geschiedenis van het javaanse werkwoord met die van andere westelijke indonesische talen, dan kan men slechts zeggen, dat de ontwikkeling in het eerstgenoemde geval minder ver gevorderd is dan b.v. in talen als het mori en het bare'e. Zonder twijfel zijn zowel in Midden-Celebes als op Java de drie grondslagen waarop het ,passieve” werkwoordstype berust, diep aangetast. In het mori en het bare'e heeft de nieuwbouw echter veel duidelijker vorm gekregen. De verschillende subjects- en objectstypen die we voor het javaans hebben ontleed, stellen blijkbaar slechts evenveel experimenten van de taal voor, om zelfstandig een nieuwe stijl te vinden, die beter aan de gewijzigde omstandigheden was aangepast. Het is hier echter bij telkens herhaald tasten en proberen gebleven. In verhouding is de verbale structuur, ook van de latere bovenbouw, in het mori en het bare'e daarom veel eenvoudiger. De overgang is in deze talen a.h.w. ineens en volkomen gelukt. Karakteristiek in dit verband is b.v. dat de ,actieve” en de "passieve" vormsystemen in het javaans morphologisch beschouwd, steeds vrij streng van elkander gescheiden zijn gebleven ${ }^{237}$ ). De (pre)nasalering is hier b.v. steeds als een even exclusief kenmerk der ",actieve" vormen blijven gelden, als de flectie dit is van het „passieve” stelsel. Een constructie als *lajangé dak-noelis $(<*$ dak-ntoelis) of, juist andersom, als *(akoe)ku-toelis (dak-toelis) lajang, die toch theoretisch wel denkbaar waren, is hier nooit ontstaan. In het

235) J. H. Kern, Verspreide Geschriften 8, 278 v.; 138 v.

238) C. C. Berg, Inleiding, op. cit. 213. Over het enclitisch-possessieve flectietype van het z.g. oud-passief, zie Berg, Bijdrage tot de kennis der javaansche werkwoordsvormen 103.

237) We zeggen hier met opzet „vrij streng”. Een opmerkelijke indicatie voor een vermenging die op andere punten heeft plaats gehad, heeft men immers in het overnemen van de drie objectsgraden ook door de "passieve" vormen. Hier beginnen de beide stelsels blijkbaar al nauwer ineen te groeien. We hebben daarover al met een enkel woord gesproken. 
Parigisch dialect van het bare'e daarentegen, wordt het nieuwe genus passivum ineens vrij en frank van één der alhier reeds bekende actievormen afgeleid.

\section{Het maleis.}

$\mathrm{Na}$ de uitvoerige beschouwingen over het javaans, waarin ook het comparatieve moment reeds naar voren is getreden, kunnen we ons bij het maleis meer dan ooit tot de hoofdzaken beperken. Wie de voornaamste maleise verbale typen in één stelsel zou willen rangschikken, juist zoals Prof. Berg dit voor het javaans heeft gedaan, zou b.v. het bijgaande schema kunnen opstellen.

Achter het zesledige systeem verbergt zich in de grond dus ook nu weer een driedeling. De hoofddistinctie ligt daarbij zowel historisch als practisch, tussen de onder 2 en 5 genoemde typen. De typen 3 en 4 staan daartussen als overgangsvormen. Men zou zich de rangschikking daarvan, juist als in het javaans, ook wel andersom kunnen denken. Het type 1, de z.g. substantiefconstructie met enclitische flectie, komt in de huidige taal niet meer voor. Haaksma heeft dit echter nog wel in de Çrivijaya-inscripties teruggevonden, juist zoals dit thans ook nog

\begin{tabular}{|c|c|c|}
\hline flectietype & morphol. kenmerk & gewone benaming \\
\hline \multirow{2}{*}{ vervoegd } & [1 subst. constructie] & \\
\hline & $2 k u-; k a u-;(d i-)$ & \multirow[b]{2}{*}{ „passief” } \\
\hline \multirow{3}{*}{ niet-vervoegd } & $\begin{array}{l}3 \text { ter- } \\
4 \text { ber- }\end{array}$ & \\
\hline & $5\left\{\begin{array}{l}m e-n \ldots \ldots \ldots \\
m e-n-\ldots \ldots \ldots . k a n \\
m e-n-\ldots \ldots \ldots-i\end{array}\right.$ & \multirow[t]{2}{*}{ „actief” } \\
\hline & $6($ mem) - per-... (-kan-i) & \\
\hline
\end{tabular}


aanwezig is in het nauw verwante minangkabau ${ }^{238}$ ). Het is in de tabel alleen op theoretische gronden toegevoegd. Het zesde type schijnt een soort verhoogde graad van het vijfde voor te stellen.

1. De verhouding van de hoofdtypen 2 en 5 is in het maleis vrijwel dezelfde als die bij de overeenkomstige javaanse typen. Bij het ,actieve” type ligt de nadruk op de agens, terwijl de patiens min of meer in de schaduw blijft. In het ,passief” daarentegen gaat de analyse juist van de patiens uit, en de agens wordt nu slechts door een instrumentale of ergatieve bepaling weergegeven. Een merkwaardig verschil tussen het maleis en het javaans is echter, dat de nasaal in de eerste taal niet alleen in staat is het ,actief" weer te geven. Men dient me- toe te voegen om geheel volledig te zijn.

Ook het bewijs, dat de termen agens en patiens in de gegeven analyse slechts een zekere beperkte betekenis kunnen hebben, wordt bij het maleis op juist dezelfde wijze geleverd als bij het javaans. Het maleise werkwoord is nooit "transitief” in dezelfde volle zin, als men ditzelfde van b.v. het werkwoord van het latijn of het grieks kan zeggen.

Er zijn verder ook hier weer niet minder dan drie manieren om het object met het werkwoord te verbinden. Men kan òfwel in het geheel niets tussenvoegen, òfwel een suffix $-k a n$, resp. $-i$ aan het werkwoord affigeren. De laatstgenoemde vorm schijnt de hoogste graad van aanschouwelijkheid voor te stellen, de suffixloze vorm daarentegen de laagste graad. Welke der drie vormen men echter ook kiest, steeds blijft de intransitieve inslag in de betekenis zeer duidelijk. Het werkwoord is dus slechts half-transitief. Vooral Gerth van Wijk heeft op deze laatste karakteristieke trek van het maleise werkwoord gewezen, zij het dan dat hij daarvoor een andere formulering heeft gekozen dan hier is geschied. Wij zullen daarom aan zijn Spraakleer enige voorbeelden ontlenen.

Zo vindt men bij -kan b.v. een aantal gevallen, waarin het object enkel een zeker instrumentaal karakter draagt ${ }^{239}$ ). Van ,getroffen worden" is hier dus zeker geen sprake.

238) R. Haaksma, Inleiding 26-28; J. L. van der Toorn, Minangkabausche Spraakkunst 121 vv.

239) D. Gerth van Wijk, Spraakleer der maleische taal 65 vv. 
zo doen door middel van iets

iets ergens in doen

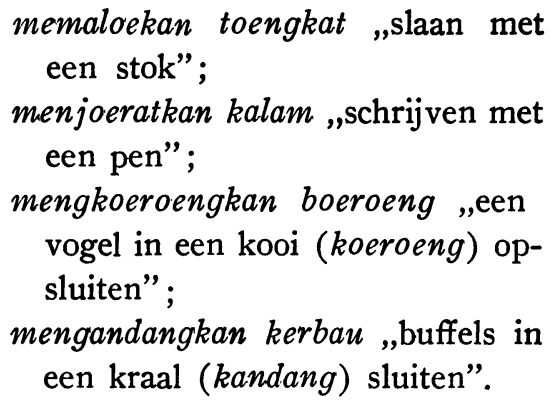

memaloekan toengkat ,slaan met een stok";

menjoeratkan kalam ,schrijven met een pen"; mengkoeroengkan boeroeng ,een vogel in een kooi (koeroeng) opsluiten";

mengandangkan kerbau ,buffels in een kraal (kandang) sluiten".

Zeer frequent is verder bij -kan ook de betekenis ten behoeve van iemand iets doen. Dat ook op deze wijze geen accusatief in de westerse zin van het woord ontstaat, is duidelijk.

Wat de woordorde in de constructie aangaat, bestaat er een vrij groot onderscheid tussen de maleise kan-vormen en de overeenkomstige javaanse $a k e ́$-vormen. De vrij strenge javaanse regels gaan in het maleis niet meer op. Bij verba van ,geven, iets voor een ander doen" etc. staat het persoonlijke ,indirecte" object in de laatste taal b.v. regelmatig tussen het werkwoord en het "directe" object, dat een zaaknaam is, ingeklampt. Dit is dus juist de omgekeerde regeling als we zoëven in het javaans hebben gezien. De oorzaak van het onderscheid zal wel in een toename der dynamische aanschouwelijkheid zijn gelegen, waardoor de aandacht naar de maleise aanvoeling voortaan, juist als in de westerse talen, allereerst naar het „directe” object uitging. Ia menjoeroeh memperboeatkan anaknja saboeah roemah ,hij beval voor zijn kind een huis te bouwen".

Bij de $i$-vormen is het „object” in werkelijkheid niets anders dan een locale bepaling. (D. Gerth van Wijk, Spraakleer der maleise taal 78 vv.). Menjoerati kartas ,op een papier schrijven, een papier beschrijven"; menoetoep ",bedekken”, maar menoetoepi ,geheel en al bedekken”; melempar "(naar) iemand of iets gooien" maar melempari orang ,herhaaldelijk (b.v. met steenen) naar iemand gooien".

Eveneens weer iets meer dynamisch, maar toch nog vrij vaag, is de relatie met het object bij de frequente betekenis ,zich als zodanig tegenover iemand (iets) gedragen”. Ialah jang meradjai kami „hij is onze vorst (radja), hij regeert ons"; mengakoei anak ,een kind als het zijne erkennen (mengakoe „ik zeggen)”; menjertai „meedoen met (serta), vergezellen". 
2. Over de maleise tussentypen 3 ter- en 4 ber-kunnen we kort zijn. In beide gevallen valt de aandacht weer vrijwel geheel op het logische subject. De betekenis is dus intransitief. Bij de ter-vormen is deze betekenis echter min of meer passief gekleurd, omdat het subject nu gewoonlijk als door een actie van buiten ,getroffen” wordt voorgesteld. $\mathrm{Bij}$ de ber-vormen daarentegen overweegt een zekere statischduratieve nuance. Het gevoel voor de dynamiek der handeling ontbreekt hier totaal. Zo vindt men b.v. de ter-vormen bij de constructies die betekenen:

(niet) zo kunnen worden of doen

kakinja tiada terangkat „zijn been kon niet opgetild worden"; tiada ia terkata-kata ,hij kon niet spreken";

bij toeval of onwillekeurig ervaren demi ia terpandang anaknja "toen (vooral van innerlijke reacties etc.) zijn blik op zijn zoon viel"; tertawa ,lachen”; tertjengang ,verbaasd zijn, stom staan van verbazing";

het passieve deelwoord

ajer jang tertimba ,het uitgeschepte water".

De statisch-intransitieve nuance der ber-vormen blijkt vooral bij de typen die van nominale oorsprong zijn:

zo zijn, zo worden, zo handelen berbanjak, ,veel worden, toenemen, vermenigvuldigen (intr.)";

voorzien zijn van wat het grond- bersetia "trouw zijn"; bersoedara woord uitdrukt etc. „broeders (zusters) van elkander zijn";

bermalam „overnachten"; berkampoeng ,zich verzamelen”; berboeah ,vruchten dragen"; bersajap ,vleugels hebben, gevleugeld".

Hoe weinig dynamisch-centrifugaal de handeling wordt doorleefd bij de ber-vormen, ziet men speciaal bij die verba waar men in de gelegenheid is twee afleidingen tegenover elkander te stellen: een met ber- en een met $m e$-. Bij de laatste vorm komt het object dan duidelijk wel als zodanig tot zijn recht, maar bij de eerste niet. $Z_{o}$ is b.v. mengobah „(iets) veranderen, anders maken" maar berobah ,anders worden". 
Ia soedah mengobah kalakoeannja ",hij heeft zijn gedrag veranderd”, maar berobahlah zearna moekanja ,zijn gelaatskleur veranderde, hij verbleekte".

Wat de met (mem-)per-samengestelde vormen aangaat, de transitieve nuance treedt hier veel meer op de voorgrond dan bij de vormen met $m e-+$ nasaal. We hebben het zesde type daarom hierboven als een soort vergrotende trap van het vijfde voorgesteld.

iemand (iets) zo maken, als zo- mempertoean ,als heer erkennen”; danig behandelen memperisteri ,tot getrouwde vrouw maken, trouwen (van een man)"; memperbaik ,in orde maken, herstellen";

iets met meer energie doen dan mempertimba = menimba ,uitgewoonlijk scheppen" (maar met het bijbegrip : voortdurend, aanhoudend).

Als geheel krijgt men de indruk, dat het maleise verbale systeem zéér nauw met het javaanse verwant is. Alleen schijnen de ,activistische" tendenzen in het eerste geval iets sterker te zijn geweest.

\section{De Batakdialecten.}

Het verbale stelsel der batakdialecten staat in allerlei opzichten tussen dat van het maleis en het javaans in. Men vindt minstens een vijftal vormgroepen, maar de grondslag is ook nu weer duidelijk een driedeling. De hoofdtegenstelling ligt tussen de typen 2 en 5 . De nos. 3 en 4 vormen overgangsgroepen, en het eerste type heeft slechts een zekere inleidende betekenis. (Figuur zie pag. 228).

1. Het eerste type, het z.g. „derde passief” bij Van der Tuuk, komt overeen met de substantief-constructie van het javaans. De vorm ontstaat door $n i-$ (resp. $-i n-$ ) aan de verbale stam toe te voegen; de persoonsconjugatie wordt achter de stam weergegeven door possessieve tekens. De graad der dynamiek is hier zeer gering. De figuur van de agens komt niet of nauwelijks tot haar recht. Men vindt de gebruikswijzen bij H. N. van der Tuuk, Tobasche Spraakkunst, 169; J. H. Meerwaldt, Handleiding voor de beoefening der bataksche taal, 44; J. H. Neumann, Schets der Karo-bataksche spraakkunst, 70.

2. De tegenstelling tussen het tweede en het vijfde type is hierin gelegen, dat de structuur in het eerstgenoemde geval vooral door de figuur van de patiens gedetermineerd wordt, maar in het laatste door 
die van de agens. Dit is dus juist hetzelfde als we reeds in het javaans en het maleis hebben gezien. Meerwaldt merkt daarbij zeker zéér terecht op, dat de batakdialecten geen ,eenvoudig passief” kennen.

\begin{tabular}{|c|c|c|}
\hline flectietype & morphol. kenmerk & $\begin{array}{c}\text { benaming bij } \\
\text { Van der Tuuk e.a. }\end{array}$ \\
\hline \multirow{2}{*}{ vervoegd } & $1 n i-$ & derde passief \\
\hline & 2 hu-; di-.. ho; di-..ibana enz. & eerste passief \\
\hline \multirow[b]{3}{*}{ niet-vervoegd } & $3 \operatorname{tar}(h a)-$ & tweede passief \\
\hline & $4 p a-n$ & versterkt passief \\
\hline & $5\left\{\begin{array}{l}m a-n \ldots \ldots \ldots \ldots \ldots \ldots \\
m a-n \ldots \ldots \ldots \ldots \ldots,-h o n \\
m a-n \ldots \ldots \ldots \ldots, i\end{array}\right.$ & actief \\
\hline
\end{tabular}

Er wordt hier altijd ,ook tevens eenigszins (gedacht) aan den persoon of de zaak, waardoor de handeling wordt verricht" (40). Men kan de term „passief”, die Van der Tuuk speciaal aan ons tweede type toekent, dus in ieder geval niet in de klassiek-indogermaanse zin van het woord opvatten. „Passief” betekent voor deze talen, juist als voor de beide vorige, ,half actief” of ,gematigd actief”.

Ook het practisch taalgebruik wijst hier overigens weer duidelijk op deze laatste karakteristiek. Zo vindt men de dubbel geaffigeerde vormen ook speciaal bij verba van beweging, richting enz. De plaats van bestemming wordt dan ingeleid door $t u$,naar”. Van een werkelijke accusatief-verhouding is hier natuurlijk geen sprake. Di-tikkir ma tu gadong ,door hem werd koers gezet naar (den akker met) gadongs".

Ook bij het vijfde constructietype blijft de verhouding tot het object nog vrij vaag, welke van de drie verbindingswijzen, die ook hier weer onderscheiden kunnien worden, men ook kiest. Zo vloeien bij de suffixloze constructie de intransitieve en de transitieve betekenisnuancen 
duidelijk min of meer in elkaar. Mambuat boru betekent b.v. niet ,een bepaald meisje trouwen" maar volkomen in het algemeen ,een meisje trouwen" = gaan trouwen; mangula kan evengoed aanduiden ,een bepaald werk verrichten" als ook ,,aan het werk zijn".

$\mathrm{Bij}$ de derde objectsvorm wordt de aanduiding door middel van $-i$ met het werkwoord verbonden. Dit is weer het meest dramatische type van het voorkomende drietal. „Het object wordt (nu) als een plaats voorgesteld", verklaart Van der Tuuk (102). We kennen deze deixisvorm al (201). Het element $-i$ is niets dan een bijvorm van $d i$,te, in, bij, naar" enz. Voorbeelden van het intransitieve gebruik heeft men hier b.v. bij gebruikswijzen als :

iets naar zijn eigen aard gebruiken mandaoni ,aan iemand geneesmiddelen (daon) toedienen"; mangalakkati „,van iets de schil (lakkat) afdoen";

zulk een houding aannemen, zich manindangi ,bij iets staan, van iets zo voortbewegen getuige zijn" (tindang); manganakkohi „langs iets naar boven gaan" (nakkok).

Ook de pluraliteit der handeling kan door het $i$-suffix worden weergegeven. De actie kan daarbij evengoed van de zijde van het subject worden beschouwd als van de kant van het object. Zo kan b.v. manakkoi ,vele dingen stelen" betekenen, maar ook ,stelen (van vele personen tesamen)".

De hon-vorm van het batak komt met de $a k e$-vorm van het javaans en de kan-vorm van het maleis overeen. „Het object.... is (nu) verwijderd", schrijft Van der Tuuk (104). De oorspronkelijke betekenis van hon is ,naar”. De intransitieve inslag blijkt zeer sprekend.

zo worden; met het oog op iets mandjadihon, ,iets doen worden, in zich zo houden wording brengen"; mamodoppon „wegens iets slapen (op eieren broeden van een vogel)"; mangadoppon ,zich met het gelaat naar iemand toekeeren".

zich zo bewegen wegens iets mangekatton ",hinken (b.v. wegens een wond)".

3. Bij de tar (ha)-vorm van de bataktalen kan de agens wel worden genoemd, maar „(diens) wil.... (blijft steeds).... buiten het spel” 
(164). Zo ontstaat de nuance van de mogelijkheid, toevalligheid, onwillekeurigheid enz. ener handeling, die we van de overeenkomstige $k e$-vormen van het javaans en de ter-vormen van het maleis reeds kennen. Van der Tuuk stelt de $\operatorname{tar}(h a)$-vormen als geheel onvervoegd voor. Is het toegevoegde pronomen echter van de derde persoon enkelvoud, dan wordt het gewone ibana ,hij" vervangen door een aan de stam gesuffigeerd teken $-s a$, dat niets anders dan een verkorting van sada ,één” schijnt te zijn. Indang ha-burwat-sa (tar-bureat-sa) ,het kan niet door hem genomen worden". Men zou in dit laatste feit toch althans een begin van flectie kunnen zien.

Het kenmerk van het ,versterkte passief” (Meerwaldt) bestaat hierin, dat nu het half-transitieve prefix mang-bij de verbale stam behouden blijft, enkel in zijn passieve vorm, d.w.z. met $p$ - als anlaut. De handeling wordt op deze wijze enigszins geintensifieerd voorgesteld (vgl. de maleise per-vormen). Vandaar ook dat het „versterkte passief” véel vaker van het „eerste passief” (type 2) wordt afgeleid dan van het „tweede" of het ,derde passief” (type 3 of 1). Bij deze laatste typen blijft de figuur van de agens immers zo vaag, dat hier nauwelijks iets te versterken valt. Sai dipan-dok do hata $i$ tu ahu ,herhaaldelijk werden die woorden (door hem) tot mij gezegd".

\section{b. Het „omzetten” van de z.g. substantief-constructie.}

De rechtstreekse toevoeging van de persoonselementen vóór aan de verbale stam is zonder twijfel de meest gewone methode, waarop in de westelijke indonesische talen een nieuw proclitisch systeem wordt geconstitueerd. Speciaal in de "centrale" ondergroep komt daarnaast echter nog een andere methode voor: het ,omzetten" van de z.g. substantiefconstructie. Al het essentielle over dit punt is reeds vermeld door Dr. S. J. Esser in zijn oriënterend artikel „Nogmaals de vervoegde vormen" ${ }^{240}$ ). We behoeven daarom enkel enige kanttekeningen daarbij te maken van comparatief standpunt.

Vooreerst wordt het uit de theoretische beschouwingen van hierboven (128 vv.) reeds duidelijk, waarom wij de substantiefconstructie, in tegenstelling met de gewone opvatting, van het begin af an reeds

240) Feestbundel van het Koninklijk Bataviaasch Genootschap van Kunsten en Wetenschappen, deel I (1929), 161 vv. 
als een type van „flectie” zouden willen opvatten. Naar onze mening heeft men hier niets anders voor zich dan één der vele voorbeelden van possessieve flectie, die de indonesische taalgeschiedenis kent. De verbale betekenis wordt door de al dan niet verdubbelde stam weergegeven, of ook wel door een ,nominale” afleiding daarvan; terwijl het possessieve teken als subjectsindex daarachter wordt gevoegd. Ook i. dit geval dient men zich immers niet door de aard der europese vertaling te laten misleiden. Over de diepere structuur van de inheemse tekst zegt deze niets. „Nomen” en ,,verbum” staan elkaar in de indonesische talen veel meer na dan dat b.v. in het nederlands het geval is. Het substantief, en a fortiori het nomen verbale, dient in de archipeltalen vrij "motorisch” en „verbaal” te worden opgevat ${ }^{241}$ ). Een rottinese constructie als nusa-a nalai-na nggafaka kan men b.v. vrij goed benaderen met ,,vanwege-het-hert loopt-het-daar-snel”. Zet men ,het hert zijn lopen is snel", zoals gewoonlijk geschiedt, dan doet men aan de inheemse structuur tekort.

Het feit, dat er in verschillende talen naast de substantiefconstructie ook nog een andere vormingswijze staat, die puur proclitisch is en gewoonlijk bij uitsluiting als ,verbaal” geldt, doet daaraan niets af. Integendeel! We weten juist uit de comparatie reeds, dat vrijwel alle indonesische talen meerdere flectietypen naast elkander bezitten. De wijze, waarop het verschijnsel der flectie in deze talen is ontstaan, bracht dit vrijwel onvermijdelijk met zich mede. Het verschil is alleen dat de uitgedrukte graad van dynamiek bij alle constructievormen niet gelijk is. Welnu, ook op dit punt vindt men hier, wat verwacht kon worden. Alle grammatici zijn het erover eens, dat de enclitischpossessieve flectie een lagere graad van ,activiteit" uitdrukt dan de overeenkomstige proclitische vorm. De gewoonlijk gegeven regel luidt, dat het gebruik der substantiefconstructie alleen dan verplicht is, indien de nadruk niet zozeer valt op het verbale feit zèlf als wel op de omstandigheden waaronder dit plaats heeft. In het omgekeerde geval fungeert de ,verbale” proclitische vorm. De overeenstemming tussen de verschillende talen op dit punt is opmerkelijk groot ${ }^{242}$ ).

241) N. Adriani, Spraakkunst der bare'e-taal 434 .

242) J. Jonker, Rottineesche Spraakkunst 445; -, Bimaneesche Spraakkunst 321 ; L. Onvlee, Eenige soembasche vertellingen LXIX; J. H. Kern, Verspreide Geschriften V, 7; VIII, 262 enz. 
Het tweede punt waarop, naar het ons voorkomt, de comparatieve beschouwing meer licht kan brengen in de huidige situatie, betreft de oorzaak waardoor de substantiefconstructie later in een aantal centrale talen is "omgezet". Men heeft hierin o.i. niets anders te zien dan een herhaling van wat ook bij het "gewone" enclitische flectietype is geschied. Ook daar kwam het overwicht op de duur op de prefixplaats te liggen. Het bewijs voor deze opvatting ligt in het feit, dat als persoonsteken vóóraan de stam niet langer het possessieve element optreedt, dat tot nu toe als zodanig heeft dienst gedaan, maar het corresponderende verbale subjectselement. Uit het "possessieve” flectietype groeit m.a.w. op deze wijze een „passieve” flectievorm, hetgeen typologisch beschouwd, een zéér grote stap vooruit betekent. Het merkwaardige is nu echter bij dit alles, dat aan de andere kant het oude nominale afleidingselement eveneens bewaard blijft in de nieuwe constructie. Zo ontstaat als geheel een typische dubbel- of overgangsvorm. We kennen dit type al uit een groot aantal voorgaande gevallen. De taal houdt enerzijds a.h.w. nog aan de oude gewoonten vast, terwijl ze anderzijds tot een nieuwe stijl overgaat (166). Dr. S. J. Esser heeft dus inderdaad volkomen terecht op dergelijke typische constructies de aandacht gevestigd. Ze bewijzen duidelijk, hoe langzaam en geleidelijk de archipeltalen zich, althans in de latere phasen, op het punt der flectie hebben ontwikkeld.

Zo heeft men b.v. bare'e risaa pa-dika-moe ,waar heb je het gelegd?" (-moe possessief), maar risaa noe-pa-dika (van ma-dika; noe-verbaal); impia pa-rata-moe papamoe ,wanneer heb je je vader aangetroffen?" maar impia noe-pa-rata papamoe (van ma-rata). Mori ndio koa meloeloe i-lako a nsala ,slechts hollende was zijn gaan”; van l-oem-ako, nomen verbale lako; $i$ - verbaal; , ,hij holde maar over den weg”.

Tenslotte verklaart de bredere vergelijking misschien ook nog, waarom de substantiefconstructie juist in de centrale indonesische talen thuis is. In de westelijke talen zijn de enclitische vormen in de latere phasen der verbale ontwikkeling reeds goeddeels verdwenen; in een taal als het maleis is daarvan in de contemporaine periode b.v. niets meer te bekennen (223). In de centrale talen echter werkte de oude nominale tweedeling met haar min of meer gelijke verdeling van de aandacht zowel over de prefixplaats als over de suffixplaats nog na. En zo hield men hier tot op zekere hoogte nog aan de enclise vast, al ziet men reeds duidelijk hoe de proclise bezig is zich daaruit en daarnaast te ontwikkelen. 


\section{c. De ontwikkeling van het casussysteem.}

We hebben tot nu toe nog enkel de verbale zijde van de ontwikkeling der westelijke indonesische talen gezien. Wat is er nu in de nominale sector, dat daaraan beantwoordt? Over de genitief in deze talen is hierboven reeds kort gesproken ( 59 v., 156 v.). Wat kan nu echter van de nominatief en de accusatief worden gezegd, de naamvallen dus die meer speciaal met het verbum in verband staan?

Veel valt hier niet te melden, evenmin als in het overeenkomstige geval bij de oostelijke talen ( $59 \mathrm{v}$.). Het voornaamste feit is zeker weer, dat ook in het westen de pronomina op dit punt in snelheid en volledigheid van ontwikkeling duidelijk de nomina vóór zijn. Hoe zich daarin opnieuw op zeer karakteristieke wijze het ,personale” karakter der gehele indonesische verbale ontwikkeling reflecteert, is hierboven reeds uitgelegd (191).

De gewone manier in de indonesische talen om de nominatief en de accusatief bij de nomina van elkander te differentiëren bestaat enkel in een nuancering van de woordorde. Meestal staat het subject vóór het praedicaat, maar het object daarachter. In gevallen van bijzondere emphase ontstaan natuurlijk speciale constructies ${ }^{243}$ ). Sporen van postpositie bij het subject, ook buiten de speciale emphase, vindt men b.v. in het bimanees en het nias. Men heeft hier naar alle waarschijnlijkheid een zeer oude methode van rangschikking voor zich. Het subject der indonesische talen heeft zich ontwikkeld uit een genitivische bepaling, die oorspronkelijk achter het nomen regens stond. In de genoemde talen is dezelfde rangorde nu blijkbaar ook bij het subject nog bewaard gebleven. Bima na-lambo-( $r a$ enz.) nahu ba doü ,een mensch slaat mij”; nias manga nina ,die Mutter isst”.

Hoe de woordorde in de verder ontwikkelde talen ten dele berust op een beginsel van incorporatie, waarbij het indirecte object als nauwer verbonden met het werkwoord voor de dag komt dan het directe object, hebben we bij de bespreking van het javaans en het maleis reeds gezien $(218,224)$. In het algemeen trouwens valt het op bij de westelijke indonesische talen, dat de datief-kategorie zich hier sneller en krachtiger

243) Over de subjects- en de objectscategorieën van het nufoor is hierboven reeds gesproken (90). Voor het tontemboan (philippijnse groep) zie N. AdrianiM. L. Adriani, geb. Gunning, Hoofdstukken uit de spraakkunst van het tontemboansch; 's Hage 1908, 192, 189. 
begint af te tekenen dan de accusatiefkategorie (bare'e, fordata, jamdena). Het is natuurlijk de typische structuur van het passieve werkwoord, die zich hier verraadt. De accusatief krijgt pas verder vorm in de talen, waar de ,activistische" trekken scherper worden.

Een enkel woord moge hier tenslotte nog gewijd worden aan het casussysteem van het nias. Sundermann heeft dit stelsel min of meer als een unicum in de indonesische talenwereld voorgesteld. In zoverre is dit inderdaad juist, als hetzelfde stelsel nergens elders op geheel dezelfde wijze in de contemporaine talen terugkeert ${ }^{244}$ ). Bij de reconstructie komt het echter overal onmiddellijk voor de dag als de oervorm, waaruit de huidige stelsels zijn ontstaan ${ }^{245}$ ). En in die zin moet dit stelsel dus eens zéér verspreid zijn geweest. Men staat hier immers voor niets dan een tegenstelling tussen een status absolutus (,,reine Form”) en een status constructus (,veränderte Form”), zoals die hierboven in onze algemene beschouwingen zijn gekarakteriseerd (93 v.). De latere ontwikkeling heeft de oorspronkelijke verhoudingen in dit opzicht slechts licht gewijzigd.

Zo staat het gepostponeerde subject in het nias b.v. steeds in de genasaleerde (,veränderte") vorm. Valt er echter meer nadruk op het subject, wordt m.a.w. de actie meer dramatisch-dynamisch gezien, en krijgt het subject in dezelfde mate scherper vorm, dan wordt dit onmiddellijk vóór het praedicaat geplaatst, en wel in de ongenasaleerde vorm. Juist op dezelfde wijze staat ook het gepostponeerde object hier in de regel in de genasaleerde vorm. Abõlõ n-angi ,der Wind ist stark" maar ama mofanõ „der Vater geht weg”; kaoni n-amagu „rufe meinen Vater".

\section{De Philippijnse talen.}

Aangezien het bij de huidige stand van het materiaal niet mogelijk is een enigszins dieper gaande comparatieve beschouwing te geven over de philippijnse groep als geheel, willen we althans het verbale

244) H. Sundermann, Niassische Sprachlehre, 's Hage 1913; 16-18, 57 v., 94-96, 101 v. A. Lafeber, Vergelijkende klankleer van het niasisch, 's Hage 1922, 39-59.

245) S. J. Esser, Klank- en vormleer van het morisch I, 241. 
stelsel der minahassische talen nagaan, waarvoor de gegevens wel toegankelijk zijn ${ }^{246}$ ).

Globaal genomen, vertoont het werkwoord der minahassische talen juist dezelfde grondtrekken als dat van de talen van Sumatra en Java. Alleen is de "schaal” van het systeem op Celebes iets meer beperkt. Kende men in de meer westelijk gelegen talen drie ,graden” of vormen

\begin{tabular}{|c|c|c|c|c|}
\hline & tontemboan & sangirees & bolaang mongondow & \\
\hline \multirow{3}{*}{ vervoegd } & $1 i \ldots \ldots \ldots \ldots$ & $1 i-\ldots \ldots \ldots \ldots$ & $(1 m o-i-\ldots \ldots \ldots)$ & \multirow{3}{*}{ „Passief” } \\
\hline & $2 \ldots \ldots \ldots-a n$ & $2(i-) \ldots-a \dot{n}(-e \dot{n})$ & $2 \ldots \ldots \ldots$-an & \\
\hline & $3 \ldots \ldots \ldots$-en & $3 i-\ldots$ & $\mid 3 \ldots \ldots \ldots \ldots-e n$ & \\
\hline niet-vervoegd & $4(m a-) n-\ldots \ldots$ & $4 n-\ldots$ & $4(m o-) n-\ldots .$. & „Actief” \\
\hline
\end{tabular}

van subject (substantiefconstructie ; ,passief”; ,,actief”) en even zoveel ,graden" van object (suffixloze verbinding; -ake(n)type; - $i$-type), in het tontemboan, het sangirees, het bolaang mongondow heeft men er daarvan telkens slechts twee. De traditie der oude nominale tweedeling met haar suffigering der inalienabile tekens moet in de Minahassa wel sterk hebben nagewerkt, zoals ook geheel met de geographische positie overeenkomt. Vandaar dat hier het enclitisch-possessieve flectietype naar verhouding veel sterker is vertegenwoordigd dan het proclitische type, dat elders in de Archipel overal voor de dag komt in de tweede phase der taalontwikkeling.

Juist omdat de minahassische talen de persoonstekens ook enkel suffigeren, kon hier verder moeilijk een tegenstelling ontstaan tussen de z.g. substantief-constructie en de ,passieve” flectie. De twee lagere graden van subject zijn op deze wijze als vanzelf in elkander gevloeid.

246) N. Adriani, Sangireesche Spraakkunst, Leiden 1893 ; - en M. L. Adriani, geb. Gunning, Hoofdstukken uit de spraakkunst van het tontemboansch, 's Hage 1908; W. Dunnebier, De voornaamwoorden in het bolaang mongondowsch, BLTV 72 (1916); - Spraakkunst van het bolaang mongondowsch BTLV 85 (1929), 297 vv., 524 vv.; 86 (1930), 42 vv. 
De tabel toont dit duidelijk. Karakteristiek in dit verband is ook, dat de pure (pre)nasalering bij het ,actief”, die men in het westen kent (javaans) tegenover de gelijktijdige voorvoeging van een prefix me-, ma- (maleis, bataktalen), op Celebes zonder beslissend onderscheid naast deze voorkomt. De laatste regeling is blijkbaar ouder en méér oorspronkelijk dan de tweede.

Het meest opvallende punt van verschil tussen de minahassische talen en die van Sumatra en Java is zonder twijfel, dat de gradatie van het object, die in het westen bij het „actief” tot uitdrukking komt, op Celebes even exclusief aan het „passief” is gebonden. Wat zich in het westen bij de hogere actiegraden voordoet, heeft zich m.a.w. op het meer centraal gelegen terrein bij de lagere graden afgespeeld. Men zal ook daarin dus wel weer een zeker retardatie-verschijnsel mogen zien, dat zeker zeer goed in het beeld der algemene indonesische ontwikkeling past. Bij de gesuffigeerde tekens vormt de vocaal het essentiële deel, de toegevoegde nasaal is enkel een verbindingselement.

De oudste tegenstelling in het objectsysteem is blijkbaar die tussen het -an- en het -en(on)-type. Een blik op de tabel leert dit onmiddellijk. Het tontemboan heeft de oorspronkelijke toestand het meest zuiver bewaard. In het sangirees is secundair het onderscheid tussen -an (-an) en $-e n(-e n)$ weer opgeheven. De keuze tussen beide suffixen hangt thans enkel van de welluidendheid af. $\mathrm{Nu}$ is $a$ in de minahassische talen een bekend locaal-deiktisch element. Het treedt elders in de taal nog op om de localis, de datief of zelfs de ablatief weer te geven. Het is dus wel duidelijk, dat men bij de -an vorm juist zulk een „indirect” objectstype voor zich heeft, als op Java en Sumatra resp. door -ake(n), -kan, -hon werd uitgedrukt. Het is de middengraad van anschouwelijkheid, die daarmede in de taal zijn aanduiding vindt. Het -en(on)-type daarentegen duidt op de hoogste graad van aanschouwelijkheid, het „directe” objectstype dat we hierboven reeds bij het $-i$-type hebben leren kennen. Dat de termen ,direct" en ,indirect" in dit verband niet naar de structuur van het actief-energetische verbale type verstaan dienen te worden, blijkt duidelijk uit het feit dat in de taal door achtervoeging van -an, resp. -en(on) ook regelmatig zuiver nominale vormen kunnen worden afgeleid. De verbale dynamiek komt hier dus slechts tot op zekere hoogte tot uitdrukking.

Ook bij de nominale afleidingen blijft overigens het typische gradatieverschil tussen -an en -en(on), dat we hebben geconstateerd, nog van 
kracht, althans in bepaalde gevallen. Bij - $a n$ is de relatie met het grondwoord duidelijk minder nauw dan bij -en(on). Zo doen b.v. in het tontemboan zowel -an als -en dienst om namen van ziekten, gebreken enz. te vormen. Bij -an worden op deze wijze echter slechts ,uitwendige verschijnselen" genoemd, die ,bij wijze van spreken, wel (weer van den persoon) afgenomen (zouden kunnen) worden". Maar bij de $e n$-vormen is het gebrek ,eene eigenschap" geworden. Sala'ag-en „,sproetig"; keter-en „krachtig, van sterkte voorzien”, maar emung-an „met een krop of struma-gezwel (emung)"; letok-an „,met vleeschkwabben (zooals de billen van een aap)" ${ }^{247}$ ).

Doen de beide enclitische "passieve" typen van de minahassische talen op allerlei punten denken aan overeenkomstige feiten uit het javaans, maleis enz., het proclitische $i$-type stelt een relatief-eigen en zelfstandige vorming voor. Ook dit type is weer het scherpst ontwikkeld in het tontemboan. Adriani spreekt hier van een ,instrumentaal passief" (188). Inderdaad is daarmede één van de meest sprekende functies van de $i$-vorm getekend. Men vindt b.v. een hele reeks constructies als em pena ro'na $i$-patitj( $\breve{e})-k u$,een pen kunnen daarmeeschrijft-het-door-mij" = een pen waarmede ik kan schrijven. Naast de instrumentale functie staan er echter nog verscheidene andere (196). Het is daarom misschien het beste te zeggen, dat het $i$-type een zekere algemene comitatieve functie heeft. Het geeft weer, dat er een zekere speciale betrekking bestaat tussen het werkwoord en de daarop volgende adstructie. Van welke aard deze betrekking precies is, hangt echter geheel af van het zinsverband. De taal drukt dit verder niet zelf uit. Men kent iets dergelijks in de indonesische taalgeschiedenis reeds uit de ontwikkeling van de z.g. possessieve flectie (128 vv.). Het verschil is alleen, dat wat zich daar tussen het subject en het werkwoord heeft afgespeeld, hier plaats heeft tussen het werkwoord en het object. Bij de andere, zojuist besproken objectsvormen van het tontemboan is de taalvorm zonder twijfel veel meer expliciet.

Men zal daarom ook wel niet mistasten, wanneer men de $i$-vorm enkel houdt voor de laagste objectsgraad van het drietal, dat deze taal op dit punt kent. Men heeft b.v. i-tow( $\breve{e})$-na-mai $m$ baja se kaju-kaju „daarginds-kwam-het-op-vanwege-hem bij-alle-gewassen” = hij deed alle gewassen opkomen (localis); em pisore iitu i-ema'-na tumbalan , bij-

247) N. Adriani-M. L. Adriani, geb. Gunning, Hoofdstukken 219, 230. 
dat-mes daarvoor-maakte-het-door-hem een-handvat" = voor dat mes maakte hij een handvat (datief); ra'itja kailekan $i$ Pokol sapa $n$ $i$-panuzer'-na ,niet wist de-gebrekkige wat daar-aldoor-werd-gezegdvanwege-hem (n.l. den andere)" = de gebrekkige wist niet wat (de ander) aldoor zeide (accusatief); mai i-pawekar a lesarera „zij-kwamen-het-daar-neerleggen op-hun-erf" $=$ zij kwamen het neerleggen op hun erf (directief).

Een tweede sterk indicium voor de vrij lage graad van object, die in de minahassische talen door de $i$-vorm wordt weergegeven, is nog dat zich juist hier allerlei verschijnselen voordoen die aan de "actieve" constructie herinneren. Men weet, waarop het onderscheid tussen het ,actief" en het "passief” in de indonesische talen berust. Het voornaamste punt is, dat de zinsstructuur in het eerste geval vooral op het logische subject is gebouwd, maar in het tweede op het logische object. De $i$-vorm was nu echter het minst uitgesproken type van object; en zo was hier naar verhouding de tegenstand tegen het invoeren van het omgekeerde constructietype ook het geringst. Het is dus weer het gewone en volkomen begrijpelijke verschijnsel uit de taalontwikkeling dat we hier opmerken: De nieuwe kategorieën groeien dáár uit de oude pendanten, waar de verwantschap van nature reeds het grootst is, resp. waar zij de minste belemmering ondervinden.

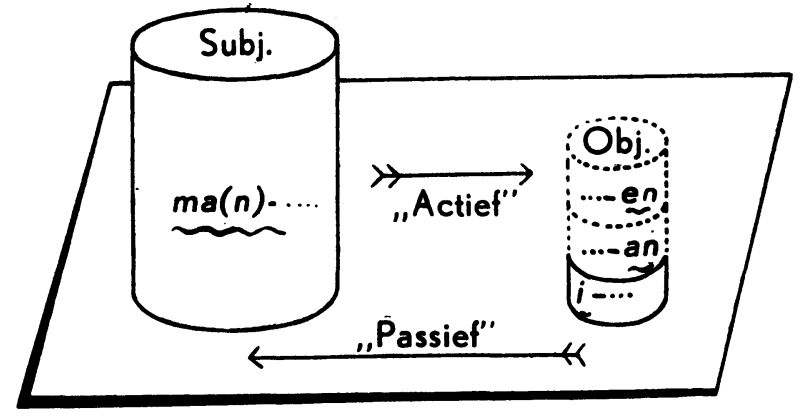

Zo staat het kenmerkende teken $i$ - in al de minahassische talen vóór de stam, juist dus op de plaats waar ook de actieve exponent pleegt te staan. In het bolaang mongondow wordt het actieve element mo- soms zelfs regelrecht aan de passieve $i$ - gekoppeld; en wel speciaal in die gevallen waar wordt uitgedrukt ,dat iemand bijgeval, bij ongeluk overkomt wat het grondwoord zegt”, of ook wel ,dat een subject toevallig, onverwachts, onopzettelijk geraakt in den toestand die door 
het grondwoord wordt te kennen gegeven" ${ }^{248}$ ). De nasaal blijft in dergelijke gevallen echter steeds weg. We hebben dit betekenistype ook in het javaans, maleis etc. reeds ontmoet. En ook daar nam dit een zekere tussenpositie tussen de "passieve" en de ,actieve" constructies in $(221,225$ v.) ; mo-i-pintoed "komen te struikelen"; no-i-tala'-koe „(dat) is door mij bij ongeluk verkeerd gedaan, door mij in zijn foutieven toestand geraakt (onopzettelijk)".

In het sangirees is het "passieve” $i$-type zelfs a.h.w. in tweeën gesplitst. De ene helft (type 3) wordt gewoon vervoegd, zoals dit ook in de verwante talen bij het "passief" de gewoonte is; maar de andere helft (type 1) kent géén vervoeging, evenmin als het blijkbaar nauwverwante ,actief" die kent ${ }^{249}$ ).

Hoe ook in de moderne europese talen een oorspronkelijk comitatieve constructie secundair gemakkelijk allerlei instrumentale en andere casusfuncties kan gaan uitdrukken, ziet men vooral bij het engelse with. Cut it with a knife (instrumentalis). He has great influence with the House (localis). I disagree with you (ablatief). It rests with you to decide (datief). The next move is with you (datief). To meet with a person, a word, an obstacle (accusatief). To bear (do, put up) with one (accusatief). Nederlands De minister sprak nog met een enkel woord over de indische kwestie (accusatief). Met grote letters schrijven (accusatief). De deugniet heeft met de zweep gekregen, maar Frans Le vaurien a reçu le fouet (accusatief). De kwajongen heeft de hond met stenen gegooid maar Le gamin a jeté des pierres au chien (accusatief). Bent $U$ bekend met de straten van Parijs? maar Connaissezvous les rues de Paris? (accusatief). Latijn latinä linguã loquor (accusatief). Sed tantum dic verbo et sanabitur anima mea (liturgische taal,

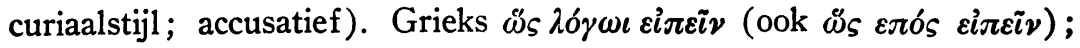
Herodotus 2, $15 ; 53$; acc.).

Voor de verhouding der -an-, -en- en $i$-typen in het tontemboan zie verder Adriani, Hoofdstukken, op. cit. 192, 196 v.v., 228 (met vele voorbeelden).

Wat de verspreiding der conjugatie aangaat, zij verder nog slechts aangetekend, dat zowel in het tontemboan als in het bolaang mongondow alle personen de toevoeging van subjectstekens kennen. In het sangirees komt dit echter enkel in het singulare voor (type 2 en 3 ).

248) W. Dunnebier, Spraakkunst van het bolaang mongondowsch, BTLV 85 (1929), 401.

249) N. Adriani, Sangireesche Spraakkunst 189 v., 191 v. 


\section{VIJFDE DEEL.}

\section{CONCLUSIES EN SAMENVATTING.}

$\mathrm{Er}$ is voor de auteur van een wetenschappelijke studie wel geen moeilijker hoofdstuk om te schrijven dan het laatste, waarin de conclusies moeten worden vermeld en een samenvatting van het gehele onderzoek gegeven.

Staat hij in de eerste hoofdstukken tegenover het objectieve materiaal en de moeilijkheden die dit biedt, in het laatste deel staat hij min of meer (ook) tegenover zichzelf. Voorzichtigheid en kritiek zijn hier dus meer dan ooit geboden. Nemo judex in causa sua! We zouden onze gedachten op dit moment daarom naar de bereikte graad van zekerheid in twee groepen willen verdelen. Er zijn bewezen feiten of „zekerheden”, en daarnaast "hypothesen” of "vermoedens”. Aan de lezer blijft uiteraard het laatste woord, of de getrokken conclusies en de daarin aangebrachte verdeling inderdaad als juist aanvaard kunnen worden of niet.

\section{I.}

1. Als bewezen mag o.i. allereerst de structuur van de subjects- en de objectskategorieën gelden, zoals die hierboven (Hoofdstuk IX, X) op grond van een breed vergelijkend onderzoek is vastgesteld. Men dient in beide gevallen met niet minder dan drie samenstellende factoren of componenten rekening te houden. De componenten zijn disjunctief relevant, d.w.z. dat elk van deze in een bepaalde taal, geheel onafhankelijk van de andere, de facto geactiveerd kan worden of niet. Ook met een zekere gradatie van elk der componenten, b.v. naar de verschillende verbale typen, dient nog rekening te worden gehouden.

Bij de kategorie van het actieve subject heeft men nu: $1^{\circ}$. dat de handelende persoon daardoor uitdrukkelijk als het centrum der verbale activiteit wordt gekenmerkt; $2^{\circ}$. dat de gedachtenanalyse en dus, ook de syntactische opbouw van de zin juist van het grammaticale subject uit- 
gaat; $3^{\circ}$. dat het grammaticale subject als index van de agens een zeer bijzondere vorm van aandacht en waardering geniet ( $86 \mathrm{vv}$.).

Juist zo vindt men bij de kategorie van het object: $1^{\circ}$. dat de genoemde grootheid daardoor uitdrukkelijk als door de verbale handeling "getroffen" wordt voorgesteld; $2^{\circ}$. dat het object in de gedachtenanalyse en dus ook in de syntactische opbouw van de zin als een noodzakelijk complement van de verbale aanduiding wordt gevoeld; $3^{\circ}$. dat het grammaticale object als index van de ,getroffen” grootheid een vrij lage graad van aandacht en waardering geniet (104 vv.).

2. Ook de gegeven verdeling der flectietypen lijkt ons voldoende gebaseerd. Men kan de verschillende flectietypen naar de uitgedrukte graad van dynamiek in een opklimmende reeks rangschikken. Enige historische of appreciatieve waarde mag aan deze indeling echter niet worden toegekend. Er zijn evengoed „dalende” als „opstijgende” ontwikkelingen mogelijk (150 vv.).

De laagste graad van dynamiek heeft men bij de z.g. possessieve flectie, die - in tegenstelling met de gewone opinie in de indonesische grammatica - als een werkelijke verbale flectie heeft te gelden. Uitgedrukt wordt nu alleen, dat de agens op het moment van zijn actie in een bijzonder nauwe betrekking tot de wereld rondom hem staat. Inderdaad zeggen ons de psychologen, dat dit punt ook werkelijk het meest op de voorgrond tredende kenmerk der handelingssituatie is. Het subject staat in de genitief (128 vv.).

De middelste graad van dynamiek wordt door het passieve werkwoord vertegenwoordigd. Men kan hier drie kenmerken vaststellen. Vooreerst wordt het subject nu door een ergativische of ablativische bepaling weergegeven. Verder is de objectskategorie, morphologisch beschouwd, slechts zeer zwak of zelfs in het geheel niet ontwikkeld. En tenslotte is het werkwoord bij dit type in oorsprong activum tantum. Samenvattend zou men van het "passieve" werkwoord als van het halfactieve of het gematigd-actieve werkwoord kunnen spreken. De kenmerken berusten op een doorleving van de handeling als een zich zo ontwikkelen, zo worden. De agens geldt daarbij enkel als een zekere organiserende en stiliserende instantie. Het betekenisstelsel is in beginsel één-dimensionaal (138 vv.).

$\mathrm{Bij}$ het actief-energetische werkwoord tenslotte triomfeert de dynamiek volkomen. De handeling is nu in haar volle verloop aanschouwelijk en geldt als een dynamisch-dramatisch proces. Het subject (casus 
activus, casus transitivus, nominatief) is typologisch de volkomen gelijkwaardige van het object (accusatief). Het betekenissysteem is tweedimensionaal. Men zou van een daar doen of een daar maken kunnen spreken. Naast het genus activum staat nu ook een genus passivum, waarbij het object het uitgangspunt der gedachte-beweging vormt (144 vv.).

3. Het werkwoord der indonesische talen valt naar onze mening onder het tweede type der gegeven indeling, d.w.z. het "passieve” of half-actieve type. Het feit, dat de gebruikte persoonstekens, etymologisch-historisch beschouwd, een zekere possessieve inslag vertonen (eerste type), doet daaraan niets af. Uit de possessieve nuance heeft zich vrijwel van het begin af aan een bepaalde ergativisch-instrumentale betekenis ontwikkeld.

Veel gewichtiger is, dat het „passieve” type der indonesische talen ten westen van de ",ijn van Brandes” en de daarmee overeenkomende isoglossen, allerlei „,activistische” trekken heeft opgenomen, echter zonder dat het oorspronkelijke karakter daardoor in de grond gewijzigd werd. De persoonstekens raken hoe langer hoe meer onder de invloed van de zelfstandige personalia, die een zekere „nominativische" waarde hebben; de objectskategorie komt steeds scherper naar voren. En in bepaalde Celebestalen ontstaat zelfs een primitief type van genus passivum. De conclusies in dit opzicht, die Dr. S. J. Esser in zijn artikel Nogmaals de vervoegde vormen (Feestbundel van het Koninklijk Bataviaasch Genootschap van Kunsten en Wetenschappen, deel I, 1929, $161 \mathrm{vv.)}$ heeft getrokken, worden door ons onderzoek ten volle bevestigd.

De ,activisten”, de grote tegenstanders der hier verdedigde traditionele „passieve” opvatting, zijn (zij het onbewust) bij hun studie uitgegaan van de verbale structuur in de klassieke westerse talen. Het begrippensysteem bleef daardoor te beperkt, en was ten dele zelfs onjuist. Anderdeels hebben zij ten onrechte ook de zojuist genoemde ,activistische" inslag, die het indonesische werkwoord in de meer westelijk gelegen talen vertoont, met het werkelijke wezen van het hier voorkomende flectietype verward. De reeds door Prof. Jonker gereconstrueerde rij van oer-indonesische subjectstekens $1 *_{k u ;}{ }^{*} m u ; 3 *_{n a}$ enz. (Over de ,vervoegde" werkwoordsvormen in de maleis-polynesische talen, BTLV 65, 1911, 266 vv.), stamt niet van de corresponderende zelfstandige personale tekens $\left(1 *_{a k u} ; 2 * k a m u\right.$ enz.), zoals 
men veelal aanneemt, maar van de serie $1 *_{k u} ; 2 m u^{*} ; 3 *_{n a}$ enz., die in de oer-austronesische periode reeds als persoonsindex fungeerde in het possessieve stelsel.

4. Historisch beschouwd, sluit de "passieve” werkwoordsopvatting onmiddellijk aan bij de distinctie tussen de alienabile en de inalienabile vorm van possessie, die thans nog slechts bij enkele van de meest oostelijke talen voorkomt, maar die vroeger veel verder in de indonesische stam verspreid moet zijn geweest. Prof. C. C. Uhlenbeck heeft reeds een dergelijke samenhang vastgesteld in een aantal noord-amerikaanse talen (Het passieve karakter van het verbum transitivum of van het verbum actionis in talen van Noord-Amerika, VMAWA 1916, 187 vv.; Het identificeerend karakter der possessieve flectie in talen van NoordAmerika, VMAWA 1917, 345 vv.). Voor de archipeltalen geldt hetzelfde.

De distinctie tussen de alienabile en de inalienabile vorm van ,possessie" heeft in de indonesische talen echter later langzaam maar zeker haar betekenis verloren. Juist zoals hier op de duur een instrumentaalergativisch type van subject is ontstaan, zo is bij de nomina (met name in de westelijke talen) ook een zeer algemeen type van genitief gegroeid.

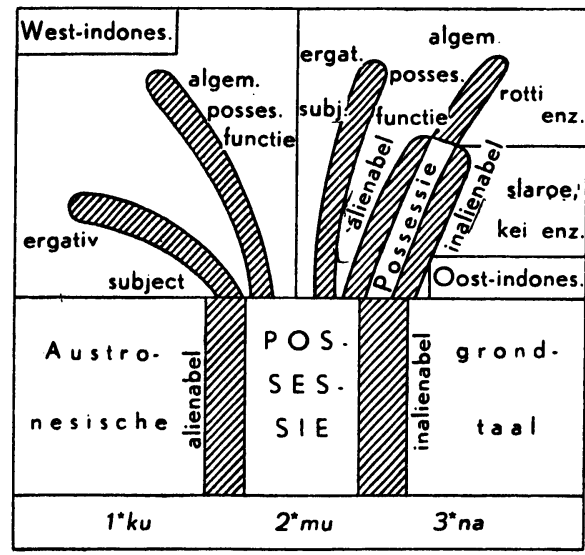

De onder 3 genoemde rij van oer-austronesische vormen $1 * k u$; $2 * m u ; 3 * n a$ enz. heeft de ontwikkeling van al dergelijke functies trouw gevolgd. Vooral opmerkelijk is daarbij de typische retardatie, die de oostelijke indonesische talen vertonen. Talen als het rottinees etc. staan gewoonlijk vrijwel op het westelijk standpunt. In meer oostelijk 
gelegen talen echter, als het slaroe, kei enz., herinnert de structuur nog duidelijk aan die der oer-austronesische grondtaal.

\section{II.}

$\mathrm{Bij}$ al dit schiften en vergelijken van de nominale en de verbale structuren, is natuurlijk ook een zekere indruk ontstaan over de genealogische stratificatie der indonesische taalgroep. Als zodanig is dit punt echter niet onderzocht en met name zijn niet telkens tegelijkertijd ook de klankverhoudingen naast elkaar gesteld. Men kan hier daarom van zeker niet meer dan „vermoedens” of „hypothesen” spreken.

1. De hoofddistinctie schijnt in de indonesische groep inderdaad te liggen tussen wat Brandes reeds in 1889 de „westelijke” en de „oostelijke afdeeling" heeft genoemd. Om aan alle feiten recht te doen schijnt men zijn vondst echter in twee richtingen nog te kunnen aanvullen.

Vooreerst is het duidelijk, naar het ons voorkomt, dat het door Brandes geponeerde, kenmerkende verschilpunt, de plaatsing van de nominale genitief, resp. achter of vóór het nomen regens, slechts een onderdeel is van een hele serie isoglossen, die op deze indeling betrekking hebben en die tezamen een zeker systeem vormen.

A. Zo vindt men in het oosten nog duidelijk de resten van een nominale tweedeling, waarbij de alienabile en de inalienabile vormen van „possessie” tegenover elkander worden gesteld. Vooral in het westen is daarvoor in de plaats echter een zeker primitief type van casusstelsel getreden.

$1^{\circ}$. Uit de ,possessie"-vormen heeft zich een genitief ontwikkeld. $2^{\circ}$. De genitief staat in het westen achter het nomen regens, in de oostelijke talen, voorzover de ontwikkeling aldaar reeds zover gevorderd is, echter daarvóór (Brandes). $3^{\circ}$. Als nominatief tegenover de nieuw gevormde genitief fungeren bij de pronomina de vormen der zelfstandige personalia, bij de nomina de gewone stamvormen. De tekening van deze kategorie is in de ,westelijke afdeeling” echter iets scherper dan in de ,oostelijke afdeeling”. $4^{\circ}$. Aan beide ,afdeelingen” gemeenschappelijk is ook de ontwikkeling van een ergatief, waarvan de pronominale vorm bij het werkwoord als geaffigeerd subjectsteken dienst doet (,passief werkwoord"). $5^{\circ}$. In de westelijke talen begint zich zelfs ook een objectskategorie te ontwikkelen. In de oostelijke talen valt daarvan geen spoor te bekennen. 
B. Bij de oplossing van het stelsel der nominale tweedeling zijn in de oostelijke talen de typische auslautswisselingen ontstaan, die Prof. Jonker zo voortreffelijk onder de naam van ,anorganische eindconsonanten" heeft bestudeerd (De eindmedeklinkers in het rottineesch en timoreesch, BTLV 7e volgreeks, 5e deel, 1906, 263 vv.). In de westelijke talen komt iets dergelijks in het geheel niet voor.

C. In de oostelijke talen is het werkwoord vrijwel zuiver ,passief”, in de westelijke talen echter beginnen duidelijk ,,activistische" trekken binnen te dringen (191 vv., $210 \mathrm{vv}$.).

Een tweede opmerkelijk punt in dit verband is, dat men aan de beschreven isoglossen blijkbaar niet enkel de "gewone” typologische betekenis kan toekennen. Men staat hier niet voor een tweedeling van een overigens vrijwel gelijkblijvende taalstructuur, maar voor een historisch groeiproces. We hebben uitvoerig gezien hoe men de „oostelijke afdeeling" in zekere zin als een strijdtoneel kan beschouwen, waar allerlei heterogene taalvormende krachten op elkander zijn gestoten, en waar daarom ook telkens zeer verschillende kruisingstypen zijn ontstaan. In de westelijke talen staat het type, dat in meer strikte opvatting indonesisch mag heten, echter ineens kant en klaar, en in een vrijwel uniforme gedaante, voor ons.

W. Schmidt en zijn leerlingen Kanski en Kaprusch hebben nu aangenomen, dat het verval der nominale tweedeling $\left(\mathrm{A} 1^{\circ}\right)$ en de vooropplaatsing van de genitief in de oostelijke talen (A $2^{\circ}$ ) berustten op de invloed van het papuasubstraat, dat in het oosten zeer krachtig zou zijn geweest. $\mathrm{Nu}$ men over zoveel meer feiten beschikt, en de gang der ontwikkeling op bepaalde punten zelfs stap voor stap kan volgen, staat men in dit opzicht zeker veel sterker. Naar onze mening is er daarom thans ook alle aanleiding, om de door W. Schmidt, en ook door Kanski en Kaprusch, slechts aarzelend en vaag gebruikte term „Mischung” in dit geval zeer concreet en zeer letterlijk op te vatten. De oostelijke indonesische talen zijn o.i. duidelijk als een groep mengtalen te beschouwen. Naast de oeroude austronesische elementen en de binnengedrongen indonesische elementen moeten ook de papuatalen hier op gelijke voet aan het proces der taalvorming hebben deelgenomen.

Dat een dergelijke gedachtengang een veel groter verspreidingsgebied voor de papua-elementen veronderstelt dan deze thans bezitten, spreekt vanzelf. W. Schmidt reeds heeft niet minder dan de gehele ,oostelijke afdeeling" daarvoor opgeëist (Die sprachlichen Verhältnisse von 
Deutsch-Neuguinea, Z A O S 5, 6, 1900 (-'01). In deze studie is echter gebleken, dat er ook in de z.g. Bima-Sumbagroep en zelfs in talen van Midden-Celebes, die wij kort als de „centrale taalgroep” hebben samengevat, veel is, dat alleen verklaard wordt, wanneer men met de inslag van meer-oostelijke elementen rekening houdt. De centrale groep is eerder een oostelijk-westelijk overgangs- en kruisingsgebied dan wel een zelfstandige ondergroep der ,westelijke afdeeling”. Zelfs talen als het nias en het atjeh vertonen zeer opmerkelijke overeenstemmingen met b.v. dialecten van Seran. Men zal zich de oude papuabevolking dus minstens wel tot aan de grote eilanden verspreid mogen denken. Of wellicht zelfs op Java, Borneo en Sumatra zelf ? De austro-asiaten, die austronesiërs en speciaal indonesiërs begonnen te worden, zullen hun zwakkere voorgangers naar de meer afgelegen delen hebben teruggedrongen, om zelf de betere streken in bezit te nemen waar zich hun leven en hun cultuur wijder en rijker kon ontplooien.

Voor de practische taalstudie volgt hieruit, dat de klassificatie der papuatalen wel één van de meest klemmende opgaven is waarvoor de onderzoeker der indonesische talen zich ziet gesteld. Zonder dat op dergelijke punten op Nieuw-Guinea klaarheid geschapen is, zal hij ook op het eigen terrein in allerlei gevallen niet tot genoegzame zekerheid kunnen komen. Ook zal men o.i. in de toekomst bij de indonesische reconstructie meer rekening met de oostelijke talen moeten houden dan tot nu toe gebruikelijk was. De westelijke talen mogen beter bekend zijn, het historische prius schijnt op verschillende punten ten oosten van de z.g. „lijn van Brandes” te liggen.

2. We hebben hierboven reeds de constantie geprezen van het pronominale paradigma $1 * k u ; 2 * m u ; 3 * n a$ enz. Inderdaad heeft men hier één van de meest sprekende rode draden voor zich, die de onderzoeker in het schemerduister der indonesische voorgeschiedenis tot gids kunnen verstrekken. Hoe de functie dezer tekens zich ook wijzigt, of de betekenis personaal of possessief, verbaal of nominaal is, de uiterlijke vorm verandert niet. Des te meer valt dit op, omdat er, als niet alle tekenen bedriegen, ook in het besproken paradigma zèlf toch nog een zekere distinctie valt te maken. De tekens $*_{k u}$ en $* m u$ schijnen personaal van oorsprong te zijn. Het derde persoonsteken *na maakt echter eerder de indruk van een demonstratief teken, ,die, die-daar”, dat hoogstens pas op weg is de betekenis „hij” te krijgen. De derde persoon is m.a.w. pas secundair aan het persoonsstelsel toegevoegd. De ge- 
bruikswijzen van na zijn daarom veel meer uitgebreid en „vrij” dan die van de beide andere personen, zoals $\mathrm{H}$. Geeroms uitvoerig heeft bewezen (Over de derde persoon meervoud in het austronesisch, BTLV $102,1943)$. Talen waarin het pronominale persoonssysteem aanvankelijk slechts twee personen telde, zijn er vele op de wereld. Ook het indogermaans b.v. behoort daartoe (K. Brugmann, Die Demonstrativpronomina der indogermanischen Sprachen, Leipzig 1904; A. Trombetti, I pronomi personali, Bologna 1908, 334 vv.). 